\title{
4. SITE 416, IN THE MOROCCAN BASIN, DEEP SEA DRILLING PROJECT LEG 50
}

\author{
The Shipboard Scientific Party ${ }^{1}$
}

\section{HOLE 416}

Date occupied: 29 September 1976, 1436 hours

Date departed: 30 September 1976, 1345 hours

Time on hole: 23 hours, 9 minutes

Position (latitude; longitude): $32^{\circ} 50.18^{\prime} \mathrm{N} ; 10^{\circ} 48.06^{\prime} \mathrm{W}$

Water depth (sea level; corrected $\mathrm{m}$, echo sounding): 4191

Water depth (rig floor; corrected m, echo sounding): 4201

Bottom felt (m, drill pipe): 4203

Penetration (m): Unknown $(<20 \mathrm{~m})$

Number of cores: 2

Total length of cored section (m): Unknown

Total core recovered $(\mathrm{m}): 1.3$

Oldest sediment cored:

Depth sub-bottom $(\mathrm{m})$ : unknown $(<20 \mathrm{~m})$

Nature: Foraminifer-nannofossil marl and ooze

Age: Late Pliocene

Basement: Not reached

Principal results: Hole 416 was drilled as a pilot hole for Hole $416 \mathrm{~A}$, to test frictional resistance of the sediment prior to setting the cone and conductor casing assembly. It is believed that after limited penetration, on the order of 10 to 20 meters, part of the bottom-hole assembly bent, and the lower end of the drill string came to rest on the sea floor.

\footnotetext{
${ }^{1}$ Yves Lancelot (Co-Chief Scientist), Départment de Géologie Dynamique, Université Pierre et Marie Curie, Paris, France; Edward L. Winterer (Co-Chief Scientist), Geological Research Division, Scripps Institution of Oceanography, La Jolla, California; Alfonso Bosellini, Geological Institute, University of Ferrara, Ferrara, Italy; Georges A. Boutefeu, Pétrofina Exploration, Brussels, Belgium (Present address: Petrangol, CP 1320, Luanda, Republic of Angola); R. E. Boyce, Deep Sea Drilling Project, Scripps Institution of Oceanography, La Jolla, California; Pavel Čepek, Bundesanstalt für Geowissenschaften und Rohstoffe, Hannover, Federal Republic of Germany; Duane Fritz, Gulf Energies and Minerals International, Houston, Texas; Eric M. Galimov, V. I. Vernadsky Institute of Geochemistry and Analytical Chemistry, U.S.S.R. Academy of Sciences, Moscow, U.S.S.R.; Marthe Melguen, Centre Océanologique de Bretagne, Brest, France; llfryn Price, The British Petroleum Company, Ltd., London, England; Wolfgang Schlager, Rosenstiel School of Marine and Atmospheric Science, Miami, Florida; William Sliter, U.S. Geological Survey, Paleontology and Stratigraphy Branch, Menlo Park, California; Kazuo Taguchi, Institute of Mineralogy, Petrology, and Economic Geology, Tohoku University, Sendai, Japan; Edith Vincent, Geological Research Division, Scripps Institution of Oceanography, La Jolla, California; and Jean Westberg, Geological Research Division, Scripps Institution of Oceanography, La Jolla, California.
}

HOLE 416A

Date occupied: 30 September 1976, 1345 hours

Date departed: 8 November 1976, 0608 hours

Time on hole: 35 days, 23 hours, 20 minutes

Position (latitude; longitude): $32^{\circ} 50.18^{\prime} \mathrm{N} ; 10^{\circ} 48.06^{\prime} \mathrm{W}$

Water depth (sea level; corrected m, echo sounding): 4191

Water Depth (rig floor; corrected m, echo sounding): 4201

Bottom felt (m, drill pipe): 4203

Penetration (m): 1624

Number of cores: 57

Total length of cored section (m): 626

Total core recovered $(\mathrm{m}): 296.2$

Core recovery $(\%): 47.3$

Oldest sediment cored:

Depth sub-bottom (m): 1624

Nature: Sandstone, calcarenite, and mudstone

Age: Kimmeridgian (early Tithonian)

Measured velocity (kmls): 2.83

Basement: Not reached

Principal results: Results obtained at Site 416 have been combined with those of nearby Site 370 to permit a reconstruction of the upper 1624 meters sampled at these sites. The section is as follows:

From 0 to about 100 meters: Pleistocene to upper Miocene. Predominantly pelagic facies. Nannofossil ooze and nannofossil marl deposited at a rate of about $10 \mathrm{~m} / \mathrm{m} . \mathrm{y}$.

From about 100 to 457 meters: Middle Miocene to middle Eocene. Sparsely sampled turbidites and hemipelagic sediments deposited at a rate of about $20 \mathrm{~m} / \mathrm{m} . \mathrm{y}$. Sediments consist of an alternation of diatom-rich nannofossil marl and chalk with graded beds of calcareous and siliceous sandstone and marlstone. The base of this unit correlates with the tan seismic reflector at 0.485 seconds, well identified on the Schlumberger logs.

From 457 to 642 meters: Middle to lower Eocene. Turbidites consisting of mudstone, siltstone, sandstone, and occasional gravel, with minor porcellanite, deposited at a rate of about $27 \mathrm{~m} / \mathrm{m}$.y. The base of this unit correlates with the red or $\mathrm{D}_{1}$ seismic reflector, well identified on the Schlumberger logs by a substantial drop in sound velocity, density, and natural gamma radiation.

From 642 to 661 meters: Paleocene. Nannofossil-bearing claystone to marlstone deposited at a very low rate (1 $\mathrm{m} / \mathrm{m}$.y). The base of this unit corresponds with a major hiatus at the Cretaceous/Tertiary boundary, identified on the logs by sharp peaks in natural gamma radiation and density. 
From 661 to about 880 meters: Albian-Barremian. Shales and mudstones. Predominantly hemipelagic, with rare turbidite sequences. The rate of accumulation for this facies is about $10 \mathrm{~m} / \mathrm{m}$.y. The base of this unit might correspond with the olive reflector, but the correlation is not obvious, even though a major and abrupt change in sediment character and organic geochemistry is observed at that level. That change might not have enough effect on the physical properties of the rocks to induce a sharp reflection.

From about 880 to 1430 meters: Hauterivian to lower Valanginian. Monotonous turbidite sequences, deposited at an average rate of $65 \mathrm{~m} / \mathrm{m} . \mathrm{y}$. The rocks are predominantly terrigenous sandstone, siltstone, and mudstone, with occasional redeposited calcareous bioclastic material derived from shelf and slope environments.

From about 1430 to 1624 meters (total depth): Lower Valanginian to Kimmeridgian (early Tithonian). Distal terrigenous facies intercalated with redeposited limestones (calcarenites to micrites) with abundant calpionellids. The rate of accumulation in this facies slows to about 10 $\mathrm{m} / \mathrm{m}$.y. All evidence shows that the total depth of 1624 meters is not far from the blue reflector.

The site was abandoned after further penetration had become impossible owing to very bad hole conditions that endangered the drill string, and after repeated attempts at logging the entire section. Good-quality logs were obtained from the uppermost 690 meters. An extensive organic-geochemistry program was conducted at this site. Although organic matter and hydrocarbon contents were extremely low and never posed safety or pollution problems, the results show that maturation stages leading to possible generation of liquid hydrocarbons were actually reached at about 1200 meters; however, generated and potential hydrocarbons remained extremely low, even below that depth.

\section{BACKGROUND AND OBJECTIVES}

The scientific objectives for Site 416 were the same as for Site 415 . They were essentially to sample old sediment, possibly of upper- to lower-Jurassic age, deposited near the base of the African margin during the early stages of evolution of the central North Atlantic.

When hole conditions at Site 415 had deteriorated to a point where chances to reach our deep objectives became very slim, we had to decide whether a second attempt should be made in the same area or whether we should transfer our hopes and frustrations to another location. The odds were that another try at or near Site 415 would probably yield the same results, assuming that our previous troubles were caused by the nature of the formations encountered near the base of the hole. Furthermore, so much time had already been spent at Site 415 that chances of reaching the basement or even of sampling a substantial section of Jurassic sediments had narrowed dramatically. One of the main reasons for choosing Site 415 as the first priority site had been the relative shallowness (depth below sea level) of the basement, but now the Agadir Canyon area had suddenly lost most of its appeal.

On the other hand, in the area of Site 370, drilled on Leg 41 , even though basement appeared equally out of reach because of the limited length of the drill string, the blue reflector and the underlying objectives were covered by much less overburden than at Site 415 . Study of the seismic profiles obtained by Meteor (see chapter on underway geophysics in this volume) also convinced us that the obstacle that had probably stopped us at Site 415 was either absent or at least not nearly as formidable in the vicinity of Site 370 (Figures 1 and 2). The interval between the red and the orange reflectors (see Site 415 report, comparison of seismic profiles and drilling results) appears indeed to decrease in thickness toward the north and at the same time to lose its incoherent character; near Site 370 it is both thin and regularly layered. An additional advantage of drilling at or very close to Site 370 was that the Mesozoic part of the upper 1176 meters of the section had already been sampled in detail and was known to pose no problems of safety or pollution prevention.

Site 416 (Figure b-1) was therefore chosen about 1.2 miles west of Site 370, along a Geophysical Service International Ltd. (GSI) seismic profile which was released to us, but which the company will not allow to be published. For the final selection of the site, we took into consideration the configuration of the lowermost layers and of the basement, keeping in mind that even if chances to reach these very deep layers during Leg 50 or during an extension were at the moment very slim, the site still might be reoccupied sometime in the future and the hole drilled to completion. For this reason we selected a site where a substantial amount of sediment appears to be present between the yellow reflector and the basement.

\section{OPERATIONS}

\section{Transit From Site 415}

In steaming from Site 415 to Site 416 , the ship followed a track parallel to and about $50 \mathrm{~km}$ west of a multifold seismic line run by Meteor, in order to provide reflection data to improve the isochron maps on various reflectors, previously controlled only by the Meteor and GSI lines (Figure 3). Unhappily, the Glomar Challenger's reflection system was not performing nearly as well as it had during the approach to Site 415 , and only relatively shallow reflectors were recorded along most of the track.

The northeast track intersected the plotted position of a GSI multifold line (Line AIR), and the ship changed course toward the east-northeast to run along this line, for later comparison with our own profiles. Isochron maps prepared by K. Hinz (pers. comm.) from Meteor and GSI data showed a structural high a few kilometers west of Site 370 , and we elected to place Site 416 between Site 370 and the top of the high. A Lamont-Doherty Geological Observatory (Vema 30-13) single-channel profile (Figure 4) made nearby along a roughly parallel track showed minor thinning of the deeper layers across the basement high, and we wanted to minimize total penetration without sacrificing stratigraphic continuity. At 1346 hours on 29 September, the beacon was dropped at the predetermined position, and we began preparations for drilling a pilot hole. The depth from the derrick floor determined from the PDR was 4201 meters. 

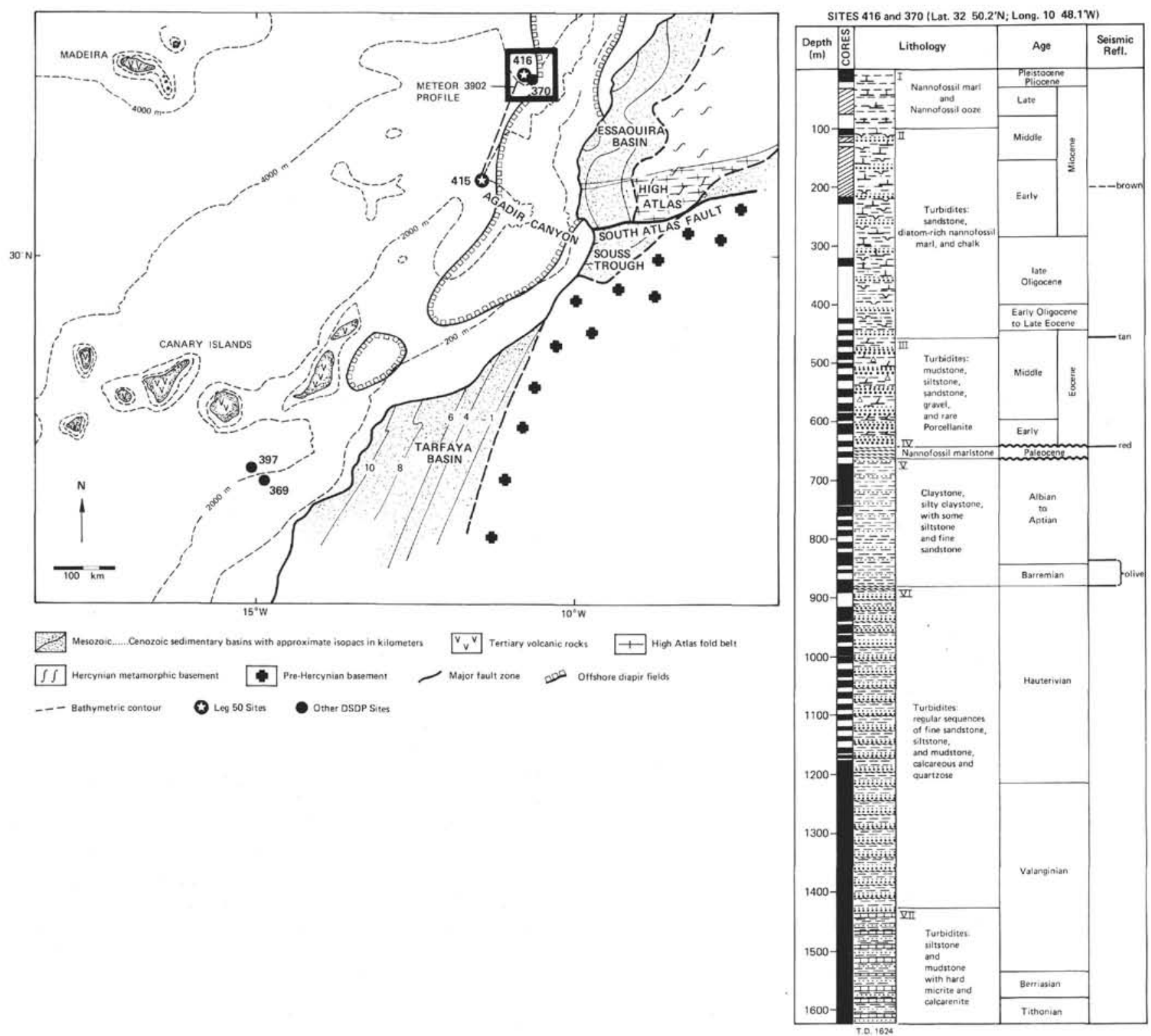

Figure 1. Location of Site 416 and graphic site summary.

\section{Hole 416}

The pilot hole was not fully successful, but it provided at least some of the facts we sought on conditions for washing-in the 16-inch casing. To all appearances, the hole went splendidly: the weight indicator wobbled at 4204 meters while a surface core (416-1) was being taken from the interval 4203 to 4205 meters. The core contained about 1.3 meters of sediment, consisting of $30 \mathrm{~cm}$ of loose foraminifer ooze overlying stiff greenish marl ooze. On the basis of this evidence, the official sea-floor depth was set at 4203 meters below the derrick floor.

The bit was raised from the sea floor during core retrieval, and then washed down to 116 meters, using gradually increasing pump pressure until the last $9.5 \mathrm{me}-$ ters, when pressure was cut back for coring. The weight on the bottom was kept at or below 10,000 pounds, according to the weight indicator at the driller's console. Washing proceeded rapidly: only 40 minutes for the 106 meters. The core barrel was left in the bottom-hole assembly for recovery at the end of the round trip. Everything looked favorable for placing about $100 \mathrm{me}-$ ters of 16 -inch casing.

The first evidence that something had gone awry came when the lowest joint of heavy drill pipe emerged from the derrick floor with a $10^{\circ}$ bend. After a few drill collars came the upper bumper sub, bent another 10 to $15^{\circ}$, and then the lower bumper sub with still another bend. The drill collars came up coated with pinkish mud, but only on one side. The core barrel contained nothing, but the throat and cones of the 14-7/8-inch bit were clogged with stiff greenish marl ooze, which proved 

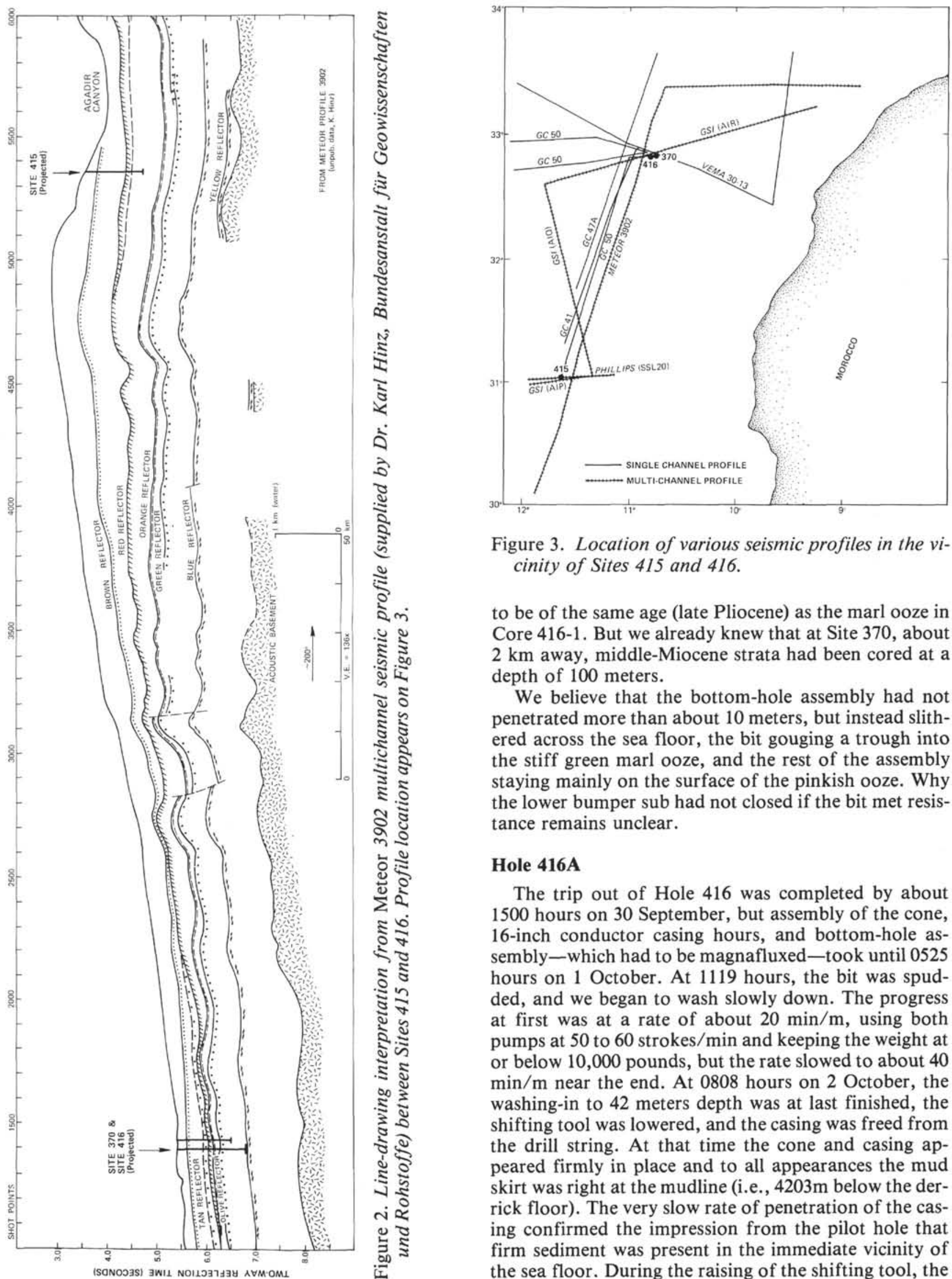

Figure 3. Location of various seismic profiles in the vicinity of Sites 415 and 416.

to be of the same age (late Pliocene) as the marl ooze in Core 416-1. But we already knew that at Site 370 , about $2 \mathrm{~km}$ away, middle-Miocene strata had been cored at a depth of 100 meters.

We believe that the bottom-hole assembly had not penetrated more than about 10 meters, but instead slithered across the sea floor, the bit gouging a trough into the stiff green marl ooze, and the rest of the assembly staying mainly on the surface of the pinkish ooze. Why the lower bumper sub had not closed if the bit met resistance remains unclear.

\section{Hole 416A}

The trip out of Hole 416 was completed by about 1500 hours on 30 September, but assembly of the cone, 16-inch conductor casing hours, and bottom-hole assembly - which had to be magnafluxed-took until 0525 hours on 1 October. At 1119 hours, the bit was spudded, and we began to wash slowly down. The progress at first was at a rate of about $20 \mathrm{~min} / \mathrm{m}$, using both pumps at 50 to 60 strokes/min and keeping the weight at or below 10,000 pounds, but the rate slowed to about 40 $\mathrm{min} / \mathrm{m}$ near the end. At 0808 hours on 2 October, the washing-in to 42 meters depth was at last finished, the shifting tool was lowered, and the casing was freed from the drill string. At that time the cone and casing appeared firmly in place and to all appearances the mud skirt was right at the mudline (i.e., $4203 \mathrm{~m}$ below the derrick floor). The very slow rate of penetration of the casing confirmed the impression from the pilot hole that firm sediment was present in the immediate vicinity of the sea floor. During the raising of the shifting tool, the 

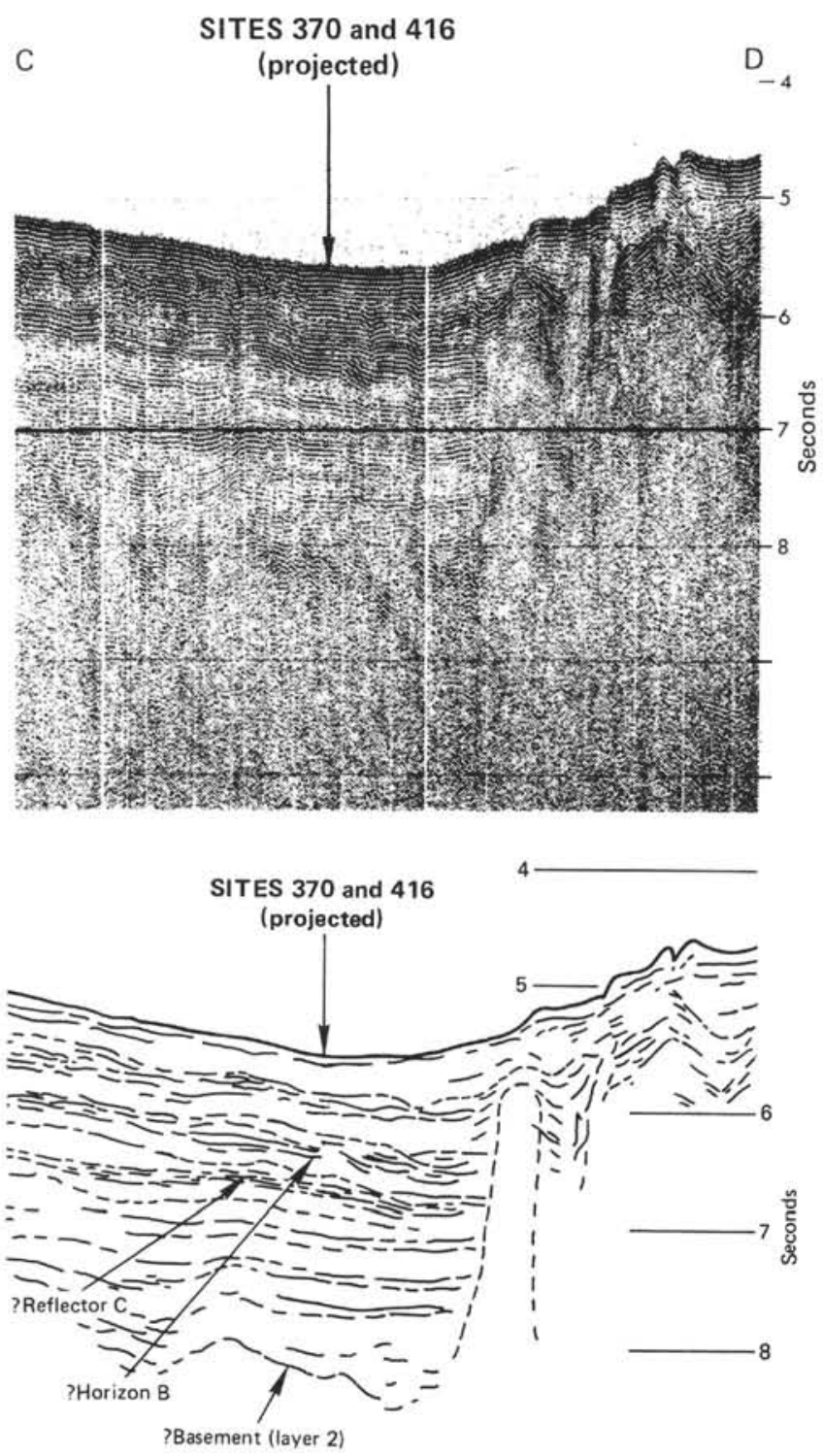

Figure 4. Lamont-Doherty Geological Observatory (Vema 30-13) single-channel seismic profile and linedrawing interpretation.

messy spooling of the wire on the sand-line winch caused repeated slowing for adjustments to the level wind, and for prying the wire into position. The raising speed for the 4200 meters averaged about $160 \mathrm{~m} / \mathrm{min}$.

At 0945 hours, the drill string was pulled out of the hole in order to replace the 14-inch bit by a normal 10 -inch coring bit. The bottom-hole assembly was on deck at 1600, and after an exchange of bits the pipe was again run to the sea floor until the bit reached 4194.5 meters below the derrick floor. That depth placed the end of the drill string approximately 6 meters above the top of the cone. The re-entry sonar tool was immediately rigged and sent down, and scanning in search of the cone began at 0301 hours on 3 October.

Clear targets corresponding to the three reflectors from the cone were acquired on the first sweep of the sonar tool. The bit was lowered to 4196.5 meters, and after a single 30-foot offset of the position toward the north the drill string swung slowly over the cone and was stabbed in at 0333 hours. The driller observed no weight release during the stabbing; after retrieving the sonar tool, the success of the re-entry was confirmed by running in more drill pipe without any incident until the bit reached the lower end of the casing and the bottom of the hole. With only moderate circulation (one pump), penetration into the sediment proceeded cautiously until the bottom-hole assembly was entirely inside the hole. Both circulation and weight on the bit then could be increased until the first core was punched from 146 to 155.5 meters sub-bottom. A drift survey at that time indicated no measurable deviation of the hole from the vertical.

Alternation of washing and coring at an approximate rate of one core per 150 meters brought the bit after cutting Core 415A-6 down to 896.5 meters sub-bottom. During drilling and coring of this interval, the average drilling time had regularly increased from less than 1 $\mathrm{min} / \mathrm{m}$ in the upper 380 meters to about 2 to $3 \mathrm{~min} / \mathrm{m}$ from 380 to 750 meters, then up to 5 to $6 \mathrm{~min} / \mathrm{m}$ from 750 to 896.5 meters, at the bottom of Core $416 \mathrm{~A}-6$. It was clear then that the reduced circulation called for by coring operations was cutting back the rate of penetration: Cores $416 \mathrm{~A}-5$ and $416 \mathrm{~A}-6$ were cut at a rate of only about $7.5 \mathrm{~min} / \mathrm{m}$.

In an effort to minimize the time loss caused by coring, and in view of the facts that (1) the same stratigraphic interval had been cored almost continuously at Site 370 (located only 1.2 miles away from Site 416) and (2) the cores recovered at both sites contained only very small amounts of hydrocarbon gas (with very high methane/ethane ratios), we decided to drill ahead without coring to the level of the total depth of Site 370 (1176.6 meters).

A center bit was lowered to replace the core barrel, to try to improve the rate of penetration. Shortly afterward, the ship started to roll as much as $8^{\circ}$, and even $12^{\circ}$ on one occasion, so rotation of the string had to be stopped. The wind had shifted slightly to the northeast and was up to a steady $24 \mathrm{mph}$, so that the heading of the ship had to be maintained at about $030^{\circ}$. A 6- to 8 -foot swell was coming from the northwest at about $70^{\circ}$ from the wind, and this caused the ship to roll more than was deemed acceptable for safe operations. Because the weatherman forecast a slight worsening of these conditions for the next 24 hours, we decided to pull out of the hole, thereby advancing the bit change so that no extra time would be lost. However, after about 5 hours, the wind velocity decreased regularly, conditions became more favorable, and drilling resumed after a wiper trip up to the mudline. During this wiping operation, the string occasionally took weight, indicating that "bridges" had developed in some sections of the hole. It then became apparent that the penetration rate using the center bit could probably be improved by replacing the bit again by a core barrel. The technique would be to drill ahead with the core barrel in place until it became filled with sediment or, more probably, until some sediment entered the barrel before friction on the inside of 
the plastic liner plugged the lower end of the barrel, and then pull it to the surface and replace it with an empty one. This technique seemed to improve the penetration down to 1090 meters sub-bottom, where progress slowed markedly.

Slow penetration was accompanied by occasional high readings on the torque indicator. Considering that the bit had logged 56 hours of rotation and thereby could be giving the first signs of extensive deterioration, we decided at 1314 hours on 7 October to pull out of the hole and replace the bit. Drift measurements taken at the level of each core indicated that hole deviation had never exceeded $1.25^{\circ}$.

During a wiper trip made while pulling out, the bit became plugged, requiring that the Bowen unit be set in place and water circulation restored until the bit was clean again. The bottom-hole assembly came to the surface at 1155 hours, and the core barrel was retrieved. It contained sediment recovered from the lower part of the hole (labeled Core 416A-7). All four cones on the bit were loose, one of them very much so, and the sediments in the core barrel showed appreciable reduction in diameter. A bit change thus appeared to have been very timely.

Before resuming drilling operations, it was decided to $\log$ the hole, and the drill string was lowered again to the sea floor, but without the bit, so that the logging tool could be lowered into the hole beyond the pipe. The sonar tool was sent down through the pipe for the second re-entry and began scanning at 0108 hours on 9 October. The lower end of the drill string was believed to be at $\mathbf{4 1 9 5 . 2}$ meters below the rig floor, that is, almost exactly at the depth from which the first re-entry had been made.

Several erratic targets appeared on the sonar scope during the search for the cone. None of these corresponded to the cone reflectors, and we interpreted them as reflections from the bottom. The sea floor was then inferred to be only about 2 to 3 meters from the sonar tool, and the drill string was raised 4 meters. In the process, the traveling block in the derrick hit the upper sheave that carries the logging line. The line jumped from the sheave and lodged itself between the sheave and its frame. The signal to the sonar tool disappeared instantly, indicating that the electric line had shorted. Upon examination from the derrick ladder, the line was found badly sheared but was judged to have still enough strength to allow for careful pulling of the sonar tool. The line was clamped off, slacked, and put back on the sheave. The sonar tool was brought back to the surface.

Next, the logging line had to be replaced. Because of the time lost during the sheave-jumping incident, and because logging of this upper part of the hole was not absolutely essential, it was decided to pull the pipe while a spare logging line was mounted on the winch, then to place a bit at the end of the drill string and continue drilling and coring operations, thereby postponing logging until the next bit change.

By the time the logging line had been replaced, the new bit was again near the sea floor, and the sonar tool was sent down in preparation for re-entry. It reached the end of the drill string at 2029 hours on 9 October, and the scanning search started. Three clear targets showed on the screen, and after only a little maneuvering the string was over the cone. Re-entry occurred at 2245 hours. The drill-string length just before stabbing in the hole read 4195 meters below the rig floor, that is, 1 meter less than during the first re-entry. Accordingly, the targets appeared some 3 feet farther than during that first operation. This suggests that the drill-string length measurement could have been in error during the aborted attempt of the previous night, and that the sonar tool at the time was indeed much too close to the sea floor, but the data from that unhappy experience still confused us.

Successful re-entry was confirmed soon, and the bit was lowered back to the bottom of the hole. During lowering, resistance was encountered at several places, and the Bowen power unit was set in place in order to use the two pumps for circulation and, later, for rotation. Several bridges in the hole required rotation to pass, but operations went smoothly until the bottom of the hole was reached at 1208 hours on 10 October. The heave compensator was then set in place, and drilling operations were resumed at 1350 hours. When penetration slowed markedly after drilling three 9.5-meter pipe lengths ahead, it was decided to pull the core barrel back to the surface. The barrel was filled with 5 meters of cuttings, although the lower part of the core might have been a sample of the actual sediment sampled in place. As soon as an empty core barrel equipped with the driftsurvey instrument was pumped and latched in place, drilling started again, at an average rate of about 5 to 8 $\mathrm{min} / \mathrm{m}$, down to a depth of 1176 meters sub-bottom, corresponding to the total depth reached at Site 370 .

From this point on, the safety and pollution-control program called for continuous coring, a requirement with which we were happy to comply, since the scientific value of continuous cores is generally much greater than that of widely spaced cores. Besides, the drilling and coring rates had now become almost equal, and unless at least two 9.5-meter lengths were drilled between cores, no time at all would be saved. However, finally the want of a proper center bit for drilling ruled out any procedure except continuous coring.

We cored continuously without incident until just past midnight on 12 October; with the bit at a depth of 1242 meters, the ship's bow thruster failed, the ship drifted about 300 feet off position, and the pipe became stuck. By 0200 hours, the thruster was running again, the ship was repositioned and the drill pipe freed. To have more working room in the derrick in the event of more trouble, the heave compensator was set aside, and coring resumed.

The next night, just after midnight, the bow thruster again failed, allowing the ship once more to drift off station, and requiring a shut-down of operations on the derrick floor until 0330 hours, when the thruster started working once more. Coring then continued without further interruption to a depth of 1403 meters (Core 416A32). A drift survey at 1336 meters showed only a $3^{\circ}$ inclination. On the other hand, the rate of penetration had slowed rather steadily, from around $8 \mathrm{~min} / \mathrm{m}$ at a 
depth of 1200 meters to around $15 \mathrm{~min} / \mathrm{m}$ near 1400 meters. By this time, the bit had rotated some 57 hours; this, and the slowing rate of coring, called for a re-entry and a change of bits.

Just before beginning to cut this last core, the wind began to freshen, and the ship became more difficult to position. After retrieving Core 416A-32 and while we were preparing to run a gamma-ray and neutron log within the drill pipe before pulling out of the hole, the positioning became more and more erratic. The winds were generally about $30 \mathrm{mph}$, with occasional gusts of $36 \mathrm{mph}$. The wind was from the northeast, while an 8-to 10 -foot swell was coming from the north-northwest. In spite of a long record by the Glomar Challenger of having operated in conditions much more severe than these, the ship's computer-controlled positioning system could not successfully maintain the vessel over the beacon, apparently because of problems in the computer itself. Operations on the derrick floor ceased, and at 1745 hours on 15 October, we decided to delay the logging to another bit-change time and to pull out of the hole, because this did not require as much power as drilling ahead, and because pulling out would remove the drill string from danger of bending or breaking in case the ship drifted far off station.

Inspection of the bit on deck showed three cones in excellent condition, and one cone loose on its bearings. The teeth were barely worn. However, because we anticipated running into rocks harder than the mudstones and marlstones that dominate down to 1400 meters, we decided to use a bit with shorter (5-mm) teeth than those in the bit just retrieved, in the belief that it would cut cores more quickly. (Our forecast was wrong.) The bottom-hole assembly was put together with three rather than two bumper subs (to permit more weight on the bit), and the stabilizer units were left out in order to eliminate any tendency they had to scrape material from the sides of the hole.

At 0145 hours on 16 October, the bit was poised just above the sea floor, but before we could begin rigging the sonar tool for re-entry, the computer began acting up again, and the ship was unable automatically to hold its position over the beacon. The winds averaged about $30 \mathrm{mph}$, and a current of 1 or 2 knots was running. At 0905 hours, the positioning system was corrected, but by this time a small boat, the Bolina, had arrived, carrying two visiting engineers and a packet of mail, and drilling operations were delayed for about an hour while the people were transferred to Glomar Challenger.

The sonar tool was sent down, and the search for the cone began at 1245 hours. Even before any targets were seen, the behavior of the tool was abnormal. First, although the end of the pipe was 4188 meters according to the driller's tally of pipe lengths, and although the winch operator reported a weight drop at 4187 meters, which indicated the tool had latched into the bit, the sonar seemingly could be lowered still further, all the while recording a typical wobbly, elliptical sea-floor echogram that steadily decreased in diameter until the tool was virtually touching the sea floor. However, the depth of the tool was now 4190 meters, whereas the sea floor was known (as confirmed by echo sounder) to be at about 4203 meters. Unless there was no bit on the end of the pipe, the sonar tool could not pass clear through, and there was every evidence that we indeed still had our bit. These effects could not be explained at the time, although the problem contained elements of the history of the unsuccessful re-entry attempt on 9 October. Suspecting that the sonar tool might be in bad shape, we pulled it back to the derrick floor to replace it with another. The first tool had globs of pipe dope clinging to it, even over parts of the transducer head itself. This material contains a lead compound and might provoke the odd behavior by blocking the transmission or receiving of echoes.

The second sonar tool began its search at 1605 hours on 16 October, and at 1828 hours the pipe stabbed into the cone for the third re-entry. While running pipe back into the hole, the first indications of slight blockages were picked up at about 200 meters. During the running-in, the positioning computer failed once again, and the ship quickly drifted about 2000 feet off its position, thus endangering the drill string. By 2140 hours, the problem was remedied, and the ship regained its position.

At about 400 meters, the resistance to lowering pipe required putting the Bowen unit into the derrick, so that the pipe could be rotated. Things went normally until about 0500 hours, when the relays for the bow thruster began sticking. This kept up until nearly 0800 hours and interrupted the rhythm of operations on the drill floor. During the last 10 meters above the previous total depth, the bit plugged, and the pipe became stuck in the hole; mud, sweat, and about 525,000 pounds of pull were required to free it.

By noon on 17 October, the bit was once again at 1403 meters, and coring could resume. The rate of coring was a great disappointment: the new bit was cutting at about $30 \mathrm{~min} / \mathrm{m}$, which is a typical rate for basalt! The cores themselves were not at all like basalt, but very much like the marlstone and claystone we had cored just above; if anything, the average hardness had been reduced. Either something had damaged the bit (the first core, 416A-33, contained a number of chunks of porcellanite that had doubtless caved from the lower-Cenozoic rocks in upper parts of the hole), or the short-toothed (\#93) button bit was entirely wrong for this type of material.

The heave compensator was used for this coring, and we started by using about 30,000 to 35,000 pounds of weight on the bit. When penetration went slowly, the weight was gradually reduced to about 15,000 pounds, with some improvement, but not enough to bring us back to the rates achieved with the previous, longertoothed bit. One problem with the heave compensator in this situation is that there are but two reserve air tanks, and to build up sufficient pressure to lighten bit weight significantly requires many hours. It is also of interest that the recovery rate for the 17 cores taken with the heave compensator was 51 per cent, whereas for the 
20 taken without it the rate was 70 per cent. There is no evidence one way or the other from Site 416 concerning the effect of the heave compensator on bit life.

After grinding away for 36 hours and progressing only 46 meters, we decided to pull the drill string and change bits. The old bit was on deck at 1110 hours on 19 October and was still like new; not a sign of wear after about 20 hours of rotation. It was now starkly clear that we had the wrong tool for the job. The only choice left was to put on a bit with slightly longer $(8-\mathrm{mm})$ teeth and try again. We had no other bits.

The next (fourth) re-entry went quickly. A good sonar target presented itself immediately, and after only a half hour of maneuvering the pipe was stabbed into the cone. During the last few tens of meters above the bottom of the hole, the pipe tended to stick a little, and the bit tended to become plugged, but by 0720 hours on the morning of 20 October the new bit was on bottom at 1450.7 meters, and coring resumed.

Coring with the longer-toothed bit returned to the rate (about $3 \mathrm{~m} / \mathrm{hr}$ ) before the third re-entry; coring continued without the heave compensator and without incident until 0810 hours on 23 October, when a hydraulic hose on the Bowen unit broke and had to be replaced, causing a delay of about $31 / 2$ hours. The replacement was the last hose in reserve (only one spare is carried). After the next core (416A-53), at a depth of 1586.2 meters, the bit had rotated about 51 hours, and we therefore decided to replace it, thereby avoiding any possibility of breaking it. This left enough time to reenter and core for several days before our scheduled departure for Funchal on 27 October. When the pipe was pulled out, we saw that the bit was in near-perfect condition.

The next (fifth) re-entry took more time than any previous attempt. The sonar tool began searching at 1020 hours on 24 October, but not until nearly 7 hours later could we manage to maneuver the vessel closer than about 30 feet from the cone. At 1705 hours, the pipe was stabbed in and lowered toward the bottom. Tight spots slowed progress half a dozen times, and at about 200 meters above the bottom progress became very slow because of a tendency for sticking after each new 19. meter section of pipe was added. We surmised that pebble-sized cavings from farther up the column were collecting in the annulus between tool joints, where they blocked free circulation and bound the drill collars. At 1307 hours, some 46 hours after cutting Core 416A-53, we began to cut Core 416A-54.

However, after the next core, new troubles began. When Core 416A-55 was retrieved, from a depth of 1605.2 meters, the barrel had lost its core-catcher assembly and all the plastic core liner. A first attempt to fish it out failed, but the second succeeded in pulling back the plastic liner with a fragment of core in the end. A third try to bring back the core catcher failed, probably because a cylinder of rock was filling the catcher, blocking access by the fishing tool. We were thus forced to pull out of the hole, but without sufficient time to reenter before having to change drilling crews in Funchal. We considered logging behind the pipe to use the time effectively, but the danger of the pipe sticking during the 10 or 12 hours required for this operation caused concern among the senior Global Marine staff. We then telephoned San Diego to try to arrange a 24-hour advance in the crew change, and, on learning that this was indeed possible, we began pulling out of the hole at 1140 hours on 26 October.

At 1405 hours on 26 October, before the last of the pipe was out of the hole, a new acoustic beacon was dropped to insure that we had a marker for our return, even though the old beacon was still functioning perfectly after some 27 days. The position of the new beacon with respect to the old beacon and to the last position of the ship at the fifth re-entry was determined (Figure 5). Core 416A-55 arrived safely on deck as about 1.5 meters of rock, partly in the core catcher and partly up in the pipe, and the rig was secured. At 2155 hours, the ship was under way for Funchal.

The trip to Funchal came at a fortuitous time when bad weather conditions might have stopped drilling had we still been at Site 416 . Soon after we left the site, the swell regularly increased to about 8 to 10 feet, while northerly winds started blowing at about $30 \mathrm{mph}$. The speed of the ship dropped to less than 8 knots during most of the day on 27 October, and to less than 7 knots on the following day, when wind speed increased to 40 $\mathrm{mph}$. The reflection-profiler records obtained during this transit are of low quality, partly because of the weather conditions. On 28 October at 1600 hours, the ship docked at Funchal in order to exchange Global Marine crews and part of the SIO technician staff. Two of the scientists also had to leave the ship because of previous commitments and family problems. Captains, Cruise Operations Managers, Department Heads, and Co-Chief Scientists agreed to take on fuel and water in order to ensure proper ballasting of the ship in marginal weather conditions.

The operations began immediately, and after exchanging crews and embarking supplies the Glomar Challenger was on her way again at 0025 hours on 20 October, only a little more than 8 hours after arrival. Large swells and 40-mph winds slowed the vessel to less than 8 knots; thus, arrival at Site 416 was not until the early afternoon of 30 October. After a minimum of maneuvering, the ship passed over the $16-\mathrm{kHz}$ beacon at 1459 hours on a $110^{\circ}$ heading. After the seismic gear had been retrieved, the ship made a Williamson turn and steamed back toward the beacon. At 1637 hours, the ship was put on automatic positioning over the beacon. This $16-\mathrm{kHz}$ beacon, which had been used through the entire first phase of drilling at Site 416, was still delivering a signal reliable enough to ensure proper positioning, and the drilling crew started immediately to lower the drill string.

At 0130 hours on 31 October, with the pipe poised at about 13 meters above the sea floor, the sonar tool was lowered, and at 0358 hours the search for the cone started. After lowering the pipe down to 4194 meters, the cone was located at a distance of approximately 380 feet from the drill bit. To begin, the ship was maneuvered arbitrarily 200 feet to the north, and the target 


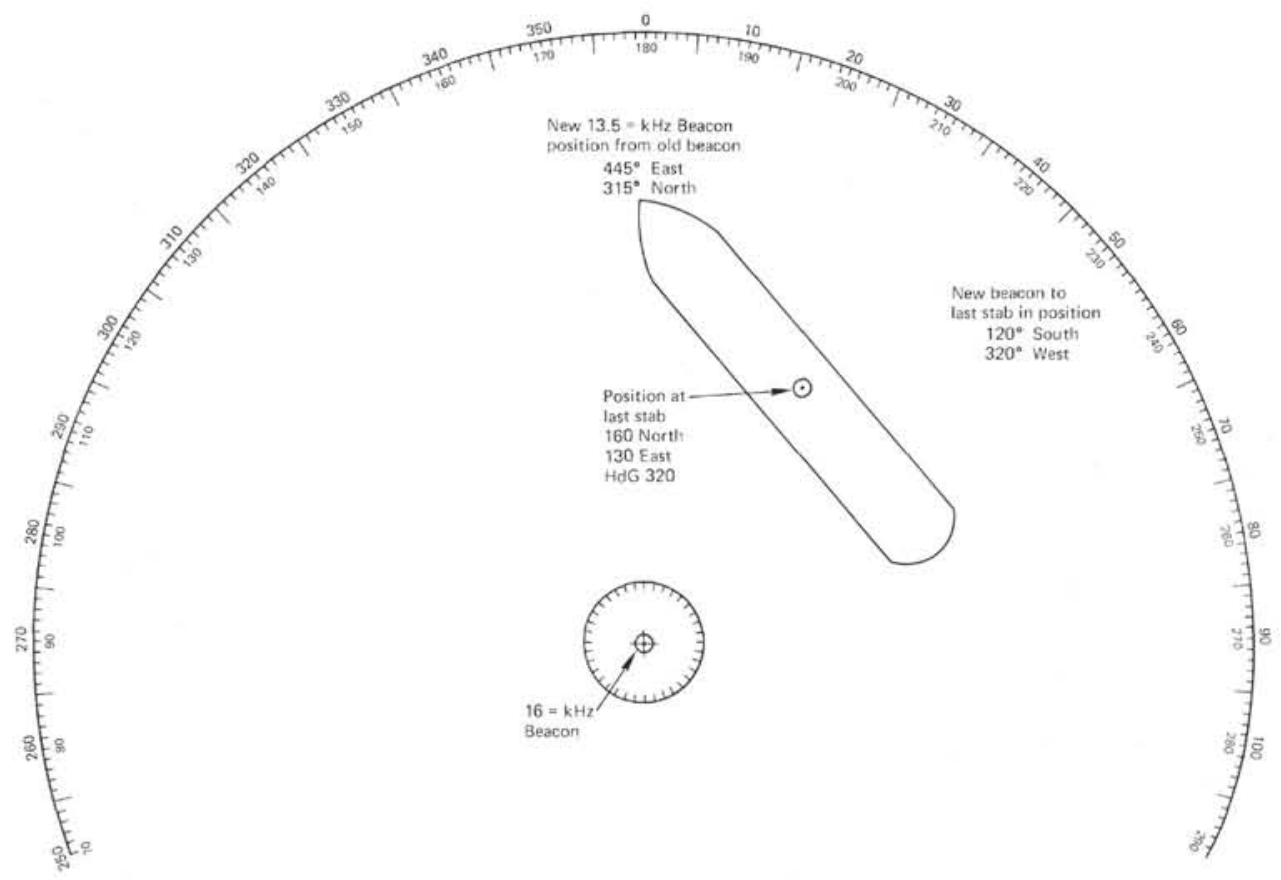

Figure 5. Positions of acoustic beacons at Site 416 and nominal position of cone at the fifth re-entry.

drew closer. After an offset to the east and several minor adjustments of position, the drill string drifted over the cone. The stab was made at 0537 hours on a clear, well-centered target. The driller did not see any oscillation on the weight indicator and the sonar tool was therefore immediately retrieved. At the time of the stab the ship was offset 300 feet to the north and 120 feet to the east of the $16-\mathrm{kHz}$ beacon. Re-entry was confirmed when more pipe ran freely into the hole.

A core barrel was pumped down to the lower end of the string, and the descent into the hole began. Operations went smoothly down to about 690 meters subbottom, where the circulation head was set on the pipe in order to wash the gel mud out of the hole. A tight spot was encountered at about 837 meters, then another one some 20 meters below, but these were cleared without difficulty. Soon thereafter another tight spot, at about 860 meters, would not yield as easily, and the circulation head was again attached to the string. The pump gauge showed the bit to be plugged, but after a little time circulation was restored. Nonetheless, the Bowen power sub was set in place to enable us to rotate the pipe and to maintain circulation through the bit. At the same time, the core barrel was retrieved in order to facilitate circulation. At 1210 hours, lowering of the pipe was resumed at a rate of approximately 3 minutes per 19-meter length, and no problem was encountered until the drill was at about 90 meters above the bottom of the hole.

From that level to the bottom, the pipe stuck repeatedly in the same manner as during the previous re-entry operation. The core barrel was pumped down at 0106 hours on 1 November, and at 0143 hours, after the drill pipe had stuck once again, coring operations at last re- sumed. Coring went surprisingly well, and Core 56 was cut in 16 minutes, with very little weight on the bit. This indicates a probable misinterpretation of the total depth reached by the drill bit, although it is not clear if the misreading occurred before or after the re-entry. The core barrel was found to contain only $30 \mathrm{~cm}$ of cutting, thereby confirming that no fresh core had been cut. Real coring started with Core 57, which was cut relatively quickly ( 99 minutes) and easily with less than 20,000 pounds of weight. The core barrel was retrieved and yielded 1.6 meters of mudstone and limestone.

New troubles began almost immediately. After the core barrel was sent down for Core 58, and after 100 barrels of mud had been pumped in the hole, the pipe became stuck and circulation was lost. Rotation was restored only after pulling very strongly on the pipe (up to 550,000 pounds) and laying down several joints of pipe, but circulation could not be restored. A center bit was dropped in to clear the throat of the bit, but it never reached the bit and was retrieved empty. At 1200 hours, a core barrel was lowered and then brought back to the surface, full of mud. Every effort to restore circulation was unsuccessful, and after a wiper trip that did not bring any improvement it was decided to pull the pipe all the way to the level of the casing and to try to pump the plug out of the drill pipe. This was also unsuccessful, and we had no other choice than to pull out of the hole. Even when the pipe was clear of the hole, circulation could not be restored, so it was evident that the lower end of the pipe was irremediably plugged.

When the bottom-hole assembly was brought to the surface at about 0200 hours on 2 November, we saw that the lowermost drill collar was completely filled with cuttings. Most of these cuttings were about 1 to $2 \mathrm{~cm}$ in 
size but many of them were as much as $4 \mathrm{~cm}$ across. A rapid examination of nannofossils in smear slides from a half dozen of these indicated that they were coming from the lower part of the hole, from strata of Tithonian to Valanginian age, and no cavings with Cenozoic fossils were discovered.

In view of the bad hole conditions, it was decided to rig a bit-release device at the lower end of the bottomhole assembly, so that if the bottom of the hole could not be reached, logging operations could start without losing the time of a trip back to the surface. Pipe was then lowered, and at 1300 hours on 2 November, the stage was set for another (our tenth) re-entry. The operation was done within 17 minutes from the time the sonar tool was lowered to the end of the string, and the sonar tool was immediately retrieved. The trip into the hole went smoothly down to about 850 meters sub-bottom, which is about the same level that had caused some trouble during the preceding re-entry, but this tight spot was passed easily with the help of the Bowen power sub. Shortly thereafter the valve at the top of the Bowen unit started leaking and had to be replaced. After two hours of work the exchange was completed, and by 0000 hours on 3 November pipe was again running down. In fact, it ran so easily that the Bowen unit was again set back in order to speed up the operation, but soon the unit had to be set in place again because both rotation and circulation were needed to push the drill string ahead.

No further difficulty was met until the 198th stand of pipe was run in. At that time the pipe became stuck a few times but still could be freed relatively easily. However, after the next connection, at a level about 80 meters above the bottom of the hole, the same symptoms recurred, and conditions rapidly deteriorated. The pipe stuck repeatedly whenever the lower two thirds of the 199th stand was lowered to the level of the rig floor. Each time the driller was able to regain rotation by pulling up several meters, but sometimes the pipe had to be pulled very hard (up to 580,000 pounds) to be freed. After numerous unsuccessful attempts at lowering the pipe past the troublesome spot, it became obvious that the drill bit would probably never reach the bottom of the hole again. Even when 300 barrels of mud were pumped down in the hole there was no visible improvement.

The causes for the recurrent sticking of the pipe were not completely understood, but the consequences of the sticking were crystal clear. It is possible that cavings started to accumulate in the annulus and that these were too large to circulate out of the hole, so they wedged themselves between the pipe and the walls of the hole. Another explanation is that there were crooked places in the lower part of the hole. In either case, we had no means to continue the struggle, and at 0745 hours on 3 November, the decision to terminate drilling operations had to be made. The total depth reached, at the base of Core 57, was then 1624 meters below the sea floor.

We now turned our efforts toward logging the hole, and at 0845 hours preparations began. After the 300 barrels of mud had been pumped down, circulation once again had become difficult, and the drill string was pulled back again. It was pulled up until rotation was restored, at a level where the bit was about 1490 meters sub-bottom. Mud then flowed back onto the rig floor whenever a stand of pipe was removed. The core barrel was retrieved and reached the surface by 1100 hours. It contained about a dozen pieces of limestone, marlstone, and mudstone, some as large as $10 \mathrm{~cm}$ across, along with approximately 1 liter of mud and small shale chips, all the material being of Early Cretaceous and Jurassic age.

The special shifting tool for releasing the bit was lowered and landed at the end of the string at 1230 hours. The release operation was apparently successful, but this shifting operation is tricky. The only way of knowing the tool has landed is by seeing a slight hesitation of the weight needle on the sand line: the tool weighs only a few hundred pounds. The sand-line length cannot be measured, because no measuring sheave for this purpose has been put on the ship - a glaring and costly omission which must be remedied. The next step in releasing was to pull up on the shifting tool. The gauge then showed more tension. This freed the bit, and the tool was lowered once more and then raised, with no more extra tension.

However, when we raised about 10 meters farther, the tension shot up again. The tool was lowered once more and then raised. After two tries, the tool could be raised without further binding. What caused this? Did we even release the bit? One further test was made: after retrieving the shifting tool, the drill string was pulled, with some difficulty, until its lower end was at 100 meters below the sea floor, so that most of the bottomhole assembly would remain within the hole during the logging operation, and while more mud was being pumped to fill the hole, it was noted that the pump pressure rose to only $500 \mathrm{psi}$ instead of the normal 1000 psi, suggesting that the bit indeed had been released.

At 2025 hours, the first logging tool, consisting of a gamma-ray-caliper-sonic assembly, was lowered within the pipe. It reached the end of the drill string at 4294 meters and could not be lowered past that point. In fact, the tool became stuck at that point and was freed only after repeated strong pulls, using tension at the safety limit of the logging cable. Thus, there was still the question of whether the bit had released or whether some other obstruction was blocking the pipe. The logging tools were raised to the surface, inspected, and found to be in good shape, with no marks. However, to make sure that the tools were narrow enough to pass through the pipe, the calipers were removed and the tool lowered once more, but with the same result: blocking at about 4295 meters. Now it was clear that only another round trip could solve our problem, so at 0300 hours we began pulling out of the hole. At 0930 hours on 4 November, the end of the pipe was on deck, and we at last saw what had caused the problem: the bit indeed had released, but while we raised the pipe through the hole, cavings entered and jammed themselves inside.

The logging shoe was screwed onto the end of the drill string, and the drill string was lowered to the bottom, and by 1951 hours on 4 November we were ready 
to try the next re-entry, to log the hole. After an hour of maneuvering the ship for a distance of several hundred feet in all directions from the supposed position of the core, without seeing any sonar target whatsoever, we suspected that pipe dope again might be smeared over the transducer, causing poor reception of signals. We therefore raised the sonar device for inspection, but found nothing wrong. A different EDO tool was sent down, to be sure, and a new search began at 0103 hours on 5 November. It was a long search, during which it was discovered that the length of the logging/EDO cable had been incorrectly recorded, and therefore an incorrect delay time was being used in the sonar display, making the sonar ranges incorrect. As a consequence, the target, located at about 420 feet, could not be seen on the sonar scope on the 500 -foot scale. Five hours later, at 0517 hours, the pipe was stabbed into the cone and run in to a depth of 4300 meters ( $97 \mathrm{~m}$ sub-bottom), and preparations for logging were made.

The first attempt-with the caliper-sonic-gamma combination-failed because the tool stuck near the bottom of the drill string. A very hard pull freed it, but broke the electrical connections, so the tool had to be retrieved for repair. Believing that the caliper-log instrument might not be passing freely out of the drill string, we removed this element from the tool and sent the sonic-gamma combination back down. All went smoothly until the tools reached about 4890 meters $(687 \mathrm{~m}$ subbottom), where an obstruction in the hole blocked further lowering, even after repeated attempts to smash through. The log was therefore run from 4890 to 4300 meters. Then followed the other logging tools: the formation-density-neutron-porosity log, the electric logs, and the temperature log. All were successful, except that the temperature log, which weighs only about $75 \mathrm{~kg}$, would go no deeper than 4790 meters (587 m sub-bottom).

The logging was finished at 0510 hours on 6 November, and we began washing ahead in order to clear the obstruction and log the deeper parts of the hole. From a depth of about 5010 to 5040 meters, the pipe met increasing resistance, with higher and higher pump pressures, and much sticking. At 5040 meters $(837 \mathrm{~m}$ subbottom), we could go no farther, so we decided to pull out to replace the logging shoe with a proper bit, to reenter, and to ream out the hole to at least 1400 meters, to finally $\log$ the lower part of the hole.

The drill string was back on deck by 1930 hours on 6 November, and while the outer core barrel was still hanging in the derrick we tried passing the Schlumberger caliper logging tool through. It failed to pass because of a flange near the top of the barrel that is only $3-7 / 8$ inches rather than 4 inches in diameter. (Hence, no more caliper logs and no diameter control on the sonic and other logs, can be obtained until the outer core barrel or the Schlumberger tool, or both, is modified. The incident points up the need for improved communications between drilling and logging engineers.

A bit and bit-release assembly were screwed on, and the pipe was run back to the sea floor. At 0613 hours on 7 November, the sonar tool was down and searching, and our last (twelfth) re-entry of Leg 50 was made at
0802 hours. Pipe was run into the hole without resistance to 4962 meters ( $759 \mathrm{~m}$ sub-bottom), where the Bowen unit was picked up and the bit washed ahead, rotating. Tight spots were met again at the same place: 5010 to 5037 meters, but then the going was easy all the way to 5636 meters (1433 m sub-bottom), where we stopped for fear of running into really bad spots ahead. The hole was filled with 500 barrels of mud; then the inner core barrel was retrieved, and the shifting tool was lowered to release the bit. At 2120 hours, the bit was released, and the pipe was pulled back to 4600 meters.

At 0040 hours on 8 November, the final logging phase began. The sonic-gamma tool was lowered through the end of the drill string ard then down to 4903 meters, where it stopped-just about where it had stopped on the previous logging runs two days earlier, before the reaming. The tool was retrieved, the circulation head was rigged, and the pipe was washed down, but it was simply an open pipe now, with no cutting edge or jetting power. At 4981 meters, the first strong resistance was met, and at 5029 meters ( $826 \mathrm{~m}$ sub-bottom) the passage was impenetrable, even when the driller allowed 40,000 pounds of weight to rest on the end of pipe. We had come to the end, and at 0608 hours on 8 November we ceased further attempts and began pulling out of the hole. The hole was left full of mud. At 1430 hours, the last of the drill string was on deck (with the end plugged with mud), and at 1500 hours the ship was under way for Funchal.

The ship first was headed toward the east to stream the geophysical gear, then it was turned back to cross over the beacon while profiling, on a course of $290^{\circ}$. At the beacon, a sonobuoy was dropped, and a wide-angle reflection survey made while steaming at 6 knots. After $1 \frac{1}{2}$ hours of poor-quality recording, the survey was completed, and the ship's speed was increased to 9 knots. The track back to Funchal was laid out to parallel the track followed on the return from Funchal to Site 416 , but about 10 miles to the north.

A summary of the cores obtained at Site 416 appears in Table 1.

\section{LITHOLOGIC SUMMARY}

At Site 416, we took only 10 cores in the upper 1176 meters, but we cored continuously below that depth. The result is that lithologic units in the upper, spotcored section cannot be defined on the basis of the core samples from Site 416 alone; rather, the down-hole logs must be used, and our few cores must be correlated with the more-complete set of cores taken at Site 370, only 2 $\mathrm{km}$ away. The correlation, based on fossils (Figure 6) ${ }^{2}$ shows that many cores in the upper section at Site 416 consist of bits and pieces collected from here and there in the interval over which the core barrel was in the drill string.

Seven lithologic units are recognized, four in the Cenozoic and three in the Mesozoic (Table 2). The composition of the sediments, estimated from smear slides

\footnotetext{
${ }^{2}$ To facilitate comparison with core-description sheets, Figures 6 and 7 are placed at the end of the chapter.
} 
TABLE 1

Coring Summary, Site 416

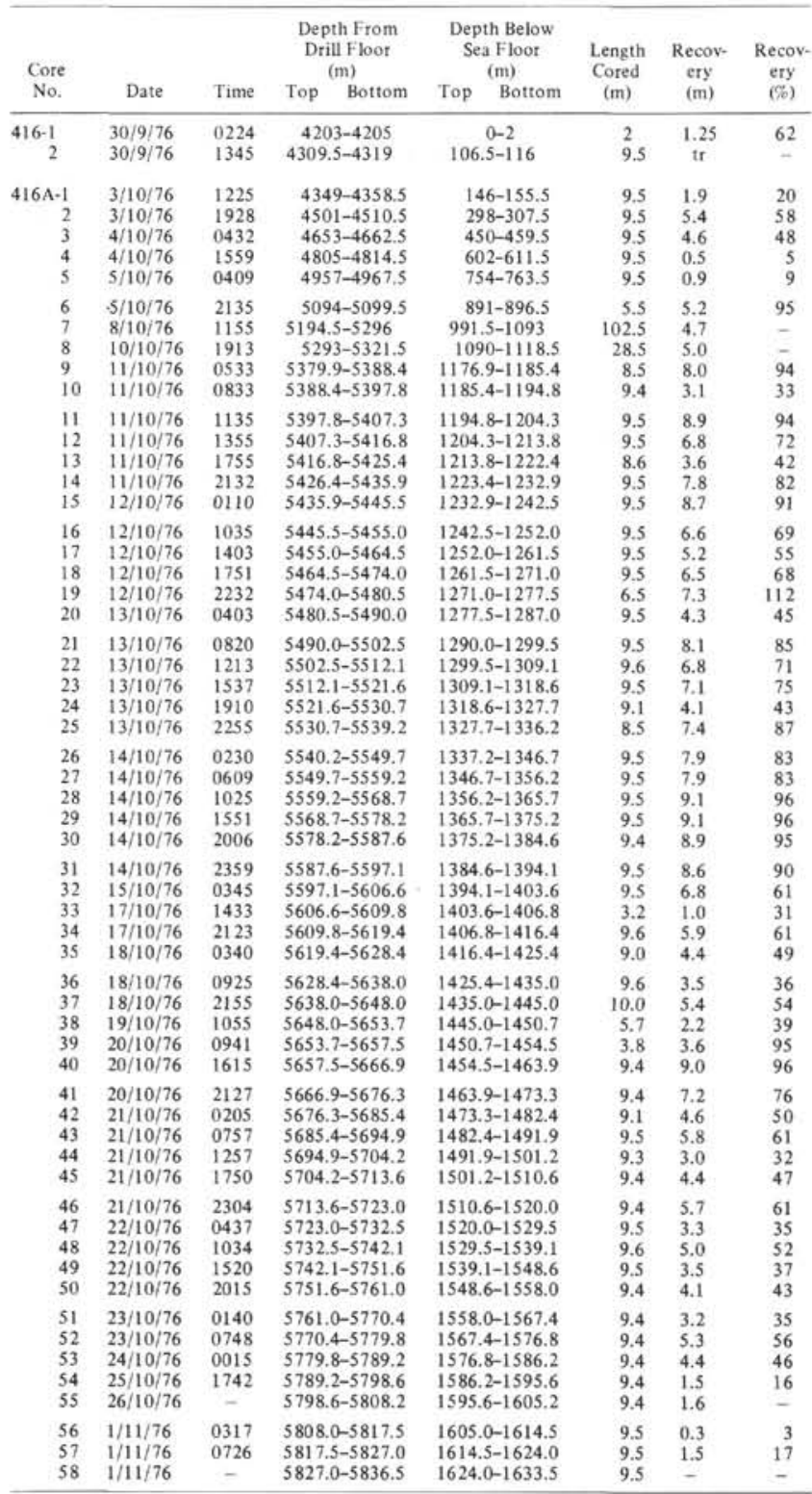

and coarse fractions, is represented in Figure $7,{ }^{3}$ and Table 3. Calcium carbonate contents appear in Table 4.

Only five widely spaced cores were recovered in the Cenozoic; thus, unit boundaries cannot be defined without evidence from down-hole logs and information from Site 370. We recognize three Cenozoic units in cores from Site 416, but the logs taken together with the coring results from Site 370 indicate a fourth unit at the base of the Cenozoic section, not cored at Site 416 .

Unit I: Nannofossil marl and nannofossil ooze. Cores $416-1$ and $416 \mathrm{~A}-1-1(0-90 \mathrm{~cm}) ; 0$ to about 100 meters; Quaternary to middle Miocene.

${ }^{3}$ To facilitate comparison with core-description sheets, Figures 6 and 7 are placed at the end of the chapter.
The various pieces of the core are shown in Figure 6 according to their contained fossils and according to an assumed even rate of accumulation for all the upperNeogene sediments, sampled and unsampled. At Site 370 , Core $370-1$ is from this unit.

This unit consists mainly of nannofossil ooze and nannofossil marl, with sharp contacts between types because of artificial condensation of samples. The lower boundary, at about 100 meters, is very uncertain: it is shallower than the top of Core 370-2, which has its nominal top at 103 meters, but this core may have included material from higher in the section. It probably is shallower than 97 meters, which is the beginning of the down-hole logs. No obvious change is seen on the logs for several hundred meters below the beginning.

The color varies from yellowish brown (10YR 5/4) for the nannofossil ooze to grayish green $(10 \mathrm{GY} 5 / 2)$ to greenish gray (5GY $6 / 1-6 / 2$ ) for the nannofossil marl. Parallel laminations are present throughout the cores, particularly in the nannofossil marl. Bioturbation is present in both cores, but more abundant in Core 416A-1, where Chondrites are well developed.

The major components are calcareous nannofossils (30-65\%), clay minerals (mainly illite and chlorite; see Chamley, this volume) (15-45\%), unspecified carbonate $(2-10 \%)$, and foraminifers $(1-15 \%)$. There are minor amounts of quartz $(1-3 \%)$, pyrite $(1-2 \%)$, and dolomite rhombs $(=2 \%)$, and trace amounts of $\mathrm{K}$-feldspar, amphiboles, micas, and glauconite. The coarse fractions also include 1 or 2 per cent of radiolarians, sponge spicules, fish remains, echinoid spines, and benthic foraminifers (see Appendix 5, this volume). The $\mathrm{CaCO}_{3}$ content ranges from 54 to 73 per cent in the calcareous ooze, and from 33 to 43 per cent in the marl.

At $416 \mathrm{~A}-1-1,15 \mathrm{~cm}$ is a slab, $5 \mathrm{~cm}$ by $1 \mathrm{~cm}$, of black, laminated, finely crystalline rock, with pyrite and a green, flaky mineral. The slab is embedded in stiff, pink, calcareous clay, and is interpreted as a clast from a gravelly layer in the upper 15 meters of the section.

Unit II: Graded sequences of sandstone, diatomrich nannofossil marl, nannofossil marl, and chalk. Cores 416A-1-1, $90 \mathrm{~cm}$ through 416A-3; about 100 to 457 meters. Middle Miocene to late middle Eocene. At Site 370, Cores 370-2 through 7.

Unit II consists of unconsolidated to poorly consolidated turbidites, interbedded with pelagic material including siliceous fossils. The upper boundary is not well defined. The lower boundary is defined from the downhole logs and is marked by sharp decreases in sonic velocity, bulk density, and resistivity, coupled with a slight increase in gamma radiation compared to the underlying unit. We have only 11 meters of recovered material from this unit at Site 416 , and 22.5 meters from Site 370.

Unit II is not subdivided, although several units in this interval were recognized at Site 370. The first turbidites appear at $416 \mathrm{~A}-1-1,90 \mathrm{~cm}$, in sediment containing fossils the same age as those in Core 370-2. Abundant diatoms appear at $416 \mathrm{~A}-1-2$, in the same biostratigraphic zone. 
TABLE 2

Lithologic Units at Sites 416 and 370

\begin{tabular}{|c|c|c|c|c|c|}
\hline Unit & $\begin{array}{l}\text { Sub-bottom } \\
\text { Depth } \\
\text { (m) }\end{array}$ & Cores, Site 416 & Cores, Site 370 & Lithology & Age \\
\hline I & $0-100$ & $\begin{array}{l}416-1 \\
416 \mathrm{~A}-1-1,0-90 \mathrm{~cm}\end{array}$ & $\begin{array}{l}370-1 \text { through } \\
370-2-2,30 \mathrm{~cm}\end{array}$ & $\begin{array}{l}\text { Nannofossil marl and nanno- } \\
\text { fossil ooze }\end{array}$ & $\begin{array}{l}\text { Pleistocene to } \\
\text { middle Miocene }\end{array}$ \\
\hline 11 & $100-457$ & $\begin{array}{l}416 \mathrm{~A}-1-1,90 \mathrm{~cm} \\
\text { through } 416 \mathrm{~A}-3\end{array}$ & $\begin{array}{l}370-2-2,30 \mathrm{~cm} \\
\text { through } 370-7\end{array}$ & $\begin{array}{l}\text { Turbidites: graded sequences } \\
\text { of sandstones, diatom-rich } \\
\text { nannofossil marls, nannofossil } \\
\text { marls and chalks }\end{array}$ & $\begin{array}{l}\text { Middle Miocene to } \\
\text { middle Eocene }\end{array}$ \\
\hline III & $457-642$ & $\begin{array}{l}416 \mathrm{~A}-4 \text { through } \\
416 \mathrm{~A}-5-1\end{array}$ & $\begin{array}{l}370-8 \text { through } \\
370-18-2\end{array}$ & $\begin{array}{l}\text { Turbidites: graded sequences } \\
\text { of mudstone, siltstone, sand- } \\
\text { stone, and gravel, with some } \\
\text { porcellanite }\end{array}$ & $\begin{array}{l}\text { Middle to } \\
\text { early Eocene }\end{array}$ \\
\hline IV & $642-661$ & Not cored at 416 & $\begin{array}{l}370-18, \mathrm{CC} \\
\text { through } 370-19\end{array}$ & $\begin{array}{l}\text { Nannofossil-bearing claystone } \\
\text { to marlstone }\end{array}$ & Paleocene \\
\hline V & $661-880$ & $\begin{array}{l}416 \mathrm{~A}-5, \mathrm{CC} \\
\text { and } 416 \mathrm{~A}-6\end{array}$ & $\begin{array}{l}370-20 \text { through } \\
370-34\end{array}$ & $\begin{array}{l}\text { Claystone and silty clay- } \\
\text { stones, with some siltstones } \\
\text { and fine sandstones }\end{array}$ & $\begin{array}{l}\text { Albian to } \\
\text { Barremian }\end{array}$ \\
\hline VI & $880-1430$ & $\begin{array}{l}416 \mathrm{~A}-7 \text { through } \\
416 \mathrm{~A}-36-2\end{array}$ & $\begin{array}{l}370-35 \text { to } \\
370-51 \text { (not } \\
\text { cored below } \\
1176 \text { m at } 370 \text { ) }\end{array}$ & $\begin{array}{l}\text { Turbidites: graded calcareous } \\
\text { and quartzose cycles, from } \\
\text { siltstone or fine sandstone to } \\
\text { mudstone }\end{array}$ & $\begin{array}{l}\text { Hauterivian to } \\
\text { Valanginian }\end{array}$ \\
\hline VII & $1430-1624$ & $\begin{array}{l}416 \mathrm{~A}-36-3 \\
\text { through } 416 \mathrm{~A}-57\end{array}$ & Not cored at 370 & $\begin{array}{l}\text { Turbidites: alternating } \\
\text { quartzose siltstone and mud- } \\
\text { stone cycles, with hard } \\
\text { micrite and calcarenite } \\
\text { (calciturbidites) }\end{array}$ & $\begin{array}{l}\text { Early Valanginian to } \\
\text { Tithonian } \\
\text { (Kimmeridgian?) }\end{array}$ \\
\hline
\end{tabular}

In Core 416A-1, the sediments are badly deformed by the coring process, and original sedimentary structures are incompletely preserved, but judging from betterpreserved sediments in Core 416A-2, unit II consists of cyclic repetitions of a sequence of (from top to base): (1) pale-green (5G 7/2-10G 6/2), foraminifer-nannofossil chalk, (2) grayish-olive (10Y 4/2), diatom-bearing nannofossil marl or mud, and (3) darker-colored, graded sand layers (not present in every cycle).

Bioturbation is present throughout, but is more abundant in the more-chalky layers. Typical cycles are illustrated in Figures 8 and 9.

The clay in the marl and mud is primarily smectite and lesser illite, but there is as much as 10 per cent attapulgite. The sand layers consist largely of planktonic foraminifers and quartz, with minor glauconite, chert grains, mica, plant fragments, benthic foraminifers, echinoid spines, radiolarians, and diatoms.

In the lowest $20 \mathrm{~cm}$ of Core 416A-2 are several subangular fragments of olive-gray chert with burrow mottles and with thin intercalations of silicified grainstone, and one subrounded pebble about $3 \mathrm{~cm}$ in diameter of finely crystalline, burrow-mottled limestone with pressure flaser structures. Very similar chert fragments are reported in Cores $370-4,6$, and 7 , from the same lithologic unit, and pebbles of mudstone containing mollusk fragments and glauconite occur in Core 370-7.

Some of the fragments in unit II are doubtless clasts from one or more gravelly turbidite layers, but some of the angular pieces of porcellanite may be in situ diage- netic nodules, detached during the drilling-and-coring process.

The calcium-carbonate content in unit II depends of course on the lithology of the part of the cycle from which a given sample was drawn. It ranges from a few per cent in the quartz-rich sand layers to more than 70 per cent in the chalky tops of some cycles. The overall trend in unit II, using data from both Site 416 and Site 370 , is a decrease in downward calcium carbonate. The turbidites are most "terrigenous" in the lower part of the unit. This is confirmed by a trend in the gamma-ray log toward increasing intensities with depth in unit II.

Unit III: Turbidites: mudstone, siltstone, graded sequences of sandstone and gravel, with some porcellanite and dolomitic marlstone. Cores 416A-4 and 5-1; 457 to 642 meters. Middle and early Eocene. At Site 370, Cores 370-8 through 18-2.

Unit III was barely sampled at Hole $416 \mathrm{~A}(50 \mathrm{~cm}$ in $416 \mathrm{~A}-4$ and $60 \mathrm{~cm}$ in 416A-5-1), so we must rely on data from Site 370 (Cores 370-8 through the upper part of $370-18$ ). The identity of the unit is very clear on the Schlumberger logs: the base of the unit is at 642 meters, corresponding to very abrupt increases in gamma radiation, bulk density, resistivity, and sonic velocity compared to the units above and below.

Unit III, like unit II, consists of turbidites, but these are mainly better consolidated and have more coarse material than in unit II, with an increase in terrigenous at the expense of pelagic components. Core $416 \mathrm{~A}-4$ contained hard chunks of pebbly mudstone, micritic nod- 
TABLE 3

Composition of Sediment Coarse Fraction, Site 416

\begin{tabular}{|c|c|c|c|c|c|c|c|c|c|c|c|c|}
\hline \multirow[b]{2}{*}{$\begin{array}{c}\text { Sample } \\
\text { (interval in } \mathrm{cm} \text { ) }\end{array}$} & \multicolumn{12}{|c|}{ Biogenic Components (\%) } \\
\hline & Bivalves & $\begin{array}{l}\text { Echino- } \\
\text { derms }\end{array}$ & $\begin{array}{l}\text { Ostra- } \\
\text { codes }\end{array}$ & $\begin{array}{l}\text { Ptero- } \\
\text { pods }\end{array}$ & $\begin{array}{l}\text { Benthic } \\
\text { Fora- } \\
\text { minifers }\end{array}$ & $\begin{array}{l}\text { Planktonic } \\
\text { Fora- } \\
\text { minifers }\end{array}$ & $\begin{array}{l}\text { Fragmented } \\
\text { Planktonic } \\
\text { Foraminifers }\end{array}$ & Diatoms & $\begin{array}{l}\text { Radio- } \\
\text { larians }\end{array}$ & $\begin{array}{l}\text { Sponge } \\
\text { Spicules }\end{array}$ & $\begin{array}{c}\text { Silico- } \\
\text { flagellates }\end{array}$ & $\begin{array}{l}\text { Fish } \\
\text { Debris }\end{array}$ \\
\hline $416-1-1,28-30$ & - & - & 1 & - & $2-3$ & $\leqslant 90$ & 2 & - & 1 & - & - & - \\
\hline $1-1,40-42$ & - & 1 & - & - & $1-2$ & 90 & $<5$ & - & - & - & - & $1-2$ \\
\hline $1-1,46-48$ & - & $<1$ & - & - & $\leqslant 1$ & 80 & 20 & - & - & - & - & $<1$ \\
\hline $1-1,67-69$ & - & 1 & - & - & $\leqslant 1$ & $>90$ & $20-30$ & - & - & - & - & 2 \\
\hline $1-1,78-80$ & - & - & - & - & 3 & $50-60$ & $20-30$ & - & - & - & - & 1 \\
\hline $1-1,84-86$ & - & 1 & - & - & 2 & 80 & $20-30$ & - & - & - & - & $\cong 1$ \\
\hline $1-1,113-115$ & - & 1 & - & - & 1 & $\cong 80$ & $20-30$ & - & - & - & - & $\approx 1$ \\
\hline $416 \mathrm{~A}-1-1,23-25$ & - & 2 & - & - & 2 & $>90$ & 25 & - & - & - & - & $1-2$ \\
\hline $1-1,85-87$ & - & $<\tilde{1}$ & - & - & $<2$ & 98 & 10 & - & - & - & - & 1 \\
\hline $1-1,95-97$ & - & - & - & - & $3-5$ & 30 & 20 & - & - & - & - & $3-5$ \\
\hline $1-1,139-140$ & - & $2-3$ & - & - & $\leqslant 1$ & 70 & $10-20$ & - & - & - & - & 2 \\
\hline $1-2,31-33$ & - & $1-2$ & - & - & 3 & $<10$ & 75 & - & 65 & 10 & - & 3 \\
\hline $1, \mathrm{CC}$ & - & 2 & - & - & $<5$ & $65-70$ & $\leqslant 10$ & - & 3 & 2 & - & 2 \\
\hline $2-1,63-65$ & - & - & - & - & $1-2$ & $>5$ & 20 & $2-3$ & 75 & 10 & - & - \\
\hline $2-1,144-145$ & - & $<2$ & - & - & $2-3$ & $<5$ & 30 & $\cong 1$ & 70 & 5 & - & $2-3$ \\
\hline $2-2,39-41$ & 1 & 2 & - & - & 2 & $\leqslant 10$ & $\cong 20$ & tr & 65 & $10-15$ & - & 3 \\
\hline $2-3,87-89$ & - & 2 & - & - & $<3$ & $\approx 10$ & 30 & $5-10$ & 60 & 10 & - & 1 \\
\hline $2-4,45-47$ & - & - & - & - & $<4$ & $3-5$ & $\cong 30$ & 5 & $>65$ & 10 & - & 3 \\
\hline $2, \mathrm{CC}$ & - & - & - & - & 3 & 20 & 20 & 2 & 20 & 3 & - & 15 \\
\hline 2,CC (top) & - & - & - & - & - & 35 & $\leqslant 10$ & 2 & 15 & 3 & - & - \\
\hline $3-1,16-18$ & - & - & - & - & 2 & - & 20 & - & 15 & 10 & - & 3 \\
\hline $3-2,32-34$ & - & - & - & - & 1 & - & - & - & 25 & 20 & - & 10 \\
\hline $3-3,10-12$ & - & - & - & - & 3 & 20 & $\leqslant 10$ & - & 20 & 25 & - & 15 \\
\hline $3 . \mathrm{CC}$ & - & - & 1 & - & $\leqslant 1$ & $<3$ & 20 & - & 2 & 2 & - & $1-2$ \\
\hline $4 . \mathrm{CC}$ & - & 1 & - & - & 2 & $<5$ & $\begin{array}{l}\text { Planktonic fora- } \\
\text { minifers almost } \\
\text { completely recryst. }\end{array}$ & - & 2 & - & - & $1-2$ \\
\hline $5-1,38-40$ & - & - & - & - & - & - & $\begin{array}{l}\text { Completely dis- } \\
\text { solved microfauna? }\end{array}$ & - & $\mathrm{tr}$ & - & - & - \\
\hline
\end{tabular}

ular limestone, conglomerate, and porcellanite. The conglomerate contains clasts of calcite-cemented quartz sandstone, chert, and porcellanite in a marly matrix. Except possibly for the porcellanites, most of these chunks are probably reworked sedimentary clasts from gravel layers.

Core 416A-5-1 contained $60 \mathrm{~cm}$ of graded and laminated sequences of color-banded alternations of greenishgray mudstone and marlstone and thin, olive-gray sandstone and siltstone layers (Figure 10).

The sandstone layers at the base of the turbidite layers consist mainly of quartz, with minor amounts of glauconite, planktonic and benthic foraminifers, and silicified lithic grains. The mudstone is somewhat dolomitic, with as much as 30 per cent rhombs scattered in a clay matrix composed almost entirely of attapulgite and sepiolite. Plant debris occurs in both the sandstone and mudstone, commonly associated with authigenic pyrite.

Porcellanite and chert occur both as isolated fragments and as silicified zones in the mudstone. The fragments may be clasts from conglomerate layers, but more likely they are nodules isolated by drilling and coring. Nodules are common in the stratigraphically equivalent rocks at Site 370; there, the upper part of unit III contains porcellanite and the lower part both porcellanite and chert.

Unit IV: Nannofossil marl and nannofossil-bearing clay. Not cored at Site $416 \mathrm{~A} ; 642$ to 661 meters. Paleocene. At Site 370, Cores 370-18,CC and 19.

We recovered no samples from unit IV, which was defined at Site 370. The down-hole logs in unit IV show low gamma radiation, and lower sonic velocity and bulk density than in adjacent units. The base is marked by a sharp peak in the gamma-ray log, as at Site 415 .
Unit V: Claystone, nannofossil claystone, and silty claystone, with minor siltstone, mudstone, and pebbly mudstone (Figure 11). Cores 416A-5, CC and 6, CC, 661 to 880 meters. Albian to Barremian. At Site 370, Cores 370-20 through 34 .

The top of unit $\mathrm{V}$ is placed at the very abrupt change in down-hole log properties at 661 meters. The gammaray log shows a very large peak here, suggesting an abnormal concentration of radioactive minerals.

In addition to clay minerals and quartz, the mudstone and siltstone contain up to 10 per cent authigenic pyrite, with traces of mica, glauconite, dolomite rhombs, and fish debris. We did not recover nannofossil claystone in this interval at Site 416A, but it was recorded at Site $\mathbf{3 7 0}$, especially above 740 meters, where it is a dominant sediment type.

The sand fraction, where present, is dominated by quartz and lithic debris (calcareous and siliceous), with plagioclase and biogenic carbonate. Thin sections of sediments cored at Site $\mathbf{3 7 0}$ show common diagenetic dolomite rhombs scattered in the claystone. Plant debris is common in both claystone and sandstone. The sandstone beds in the lower part of the unit contain, in addition to quartz, abundant redeposited shallow-water calcareous debris: mollusks and benthic foraminifers; fragments of older limestone, chert and sandstone; and small percentages of glauconite and phosphatic fish debris. The sandstone layers are commonly cemented by very coarse (1-mm), sparry, "luster-mottle" cement.

Unit VI: Distal turbidites (calcareous and siliceous). Cores 416A-7 to 416A-36-2; about 880 to 1430 meters. Hauterivian to Valanginian. At Site 370 , Cores $370-35$ through 51 . 
TABLE 3 - Continued

\begin{tabular}{|c|c|c|c|c|c|c|c|c|c|c|c|}
\hline \multicolumn{4}{|c|}{$\begin{array}{l}\text { Terrigenous Components } \\
(\%)\end{array}$} & \multicolumn{4}{|c|}{$\begin{array}{l}\text { Authigenic Components } \\
(\%)\end{array}$} & \multirow[b]{2}{*}{$\begin{array}{c}\text { Volcanic } \\
\text { Glass } \\
(\%)\end{array}$} & \multirow[b]{2}{*}{$\begin{array}{l}\text { Calcareous } \\
\text { Aggregates }\end{array}$} & \multirow[b]{2}{*}{ Remarks } & \multirow[b]{2}{*}{$\begin{array}{c}\text { Lithologic } \\
\text { Units }\end{array}$} \\
\hline Quartz & Micas & $\begin{array}{l}\text { Plant } \\
\text { Debris }\end{array}$ & Pyrite & $\begin{array}{l}\text { Glauco- } \\
\text { nite }\end{array}$ & $\begin{array}{l}\text { Dolomite } \\
\text { Rhombs }\end{array}$ & Zeolites & Chert & & & & \\
\hline 4 & 1 & - & 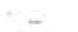 & - & - & - & - & _- & - & No sorting & \\
\hline 4 & $1-2$ & - & $1-2$ & tr & - & - & - & - & - & No sorting & \\
\hline$\leqslant 5$ & - & - & - & tr & - & - & - & - & 10 & & \\
\hline 3 & - & - & - & 1 & - & - & - & - & $2-3$ & & \\
\hline$<5$ & $<1$ & - & - & $<1$ & - & - & - & - & $\leqslant 40$ & No sorting & \\
\hline 10 & $<1$ & - & $3-5$ & 1 & - & - & - & - & - & & I \\
\hline $10-15$ & $<1$ & - & 3 & 1 & - & - & - & - & - & & \\
\hline 1 & tr & - & - & - & - & - & - & _- & _- & & \\
\hline tr & tr & - & - & - & - & - & - & - & - & & \\
\hline 55 & 2 & - & - & 2 & - & - & - & - & - & No sorting & \\
\hline 25 & - & - & - & $i$ & - & - & - & - & - & Now soting & \\
\hline 5 & - & - & - & $1-3$ & - & - & - & - & - & & \\
\hline 10 & - & - & - & 10 & - & - & - & - & - & & \\
\hline $2-3$ & - & - & - & $2-3$ & - & - & - & - & - & & \\
\hline & 1 & - & $<1$ & 2 & - & - & - & - & 3 & Well-preserved radiolarians, dissolved diatoms & \\
\hline $1-2$ & $1-2$ & - & - & _ & - & _- & - & - & - & 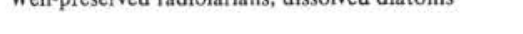 & \\
\hline 2 & - & - & - & 2 & - & - & - & - & - & & \\
\hline- & - & - & - & tr & - & - & - & - & 2 & Radiolarians and diatoms well preserved & \\
\hline 30 & - & - & 1 & 5 & - & - & - & - & - & 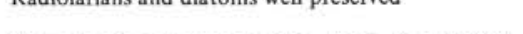 & II \\
\hline $15-20$ & - & - & - & - & - & - & 5 & - & 20 & Chert debris and complete silic. plank. foraminifers & \\
\hline 30 & 1 & - & - & $1-2$ & - & - & - & - & 3 & $\begin{array}{l}\text { Siliceous microfauna poorly preserved } \\
\text {. }\end{array}$ & \\
\hline 30 & 2 & - & - & 2 & - & - & - & - & 10 & & \\
\hline 10 & 2 & - & - & 3 & - & - & - & - & - & Coarse fraction extremely reduced & \\
\hline 85 & 2 & - & 1 & $1-2$ & $\leqslant 1$ & - & - & - & - & Coarse fraction extremely reduced & \\
\hline 85 & - & - & - & - & - & - & 2 & - & - & Coarse fraction extremely reduced & \\
\hline 10 & - & - & - & - & $1-2$ & - & - & _ & $\geqslant 90$ & Almost no coarse fraction & \\
\hline
\end{tabular}

Unit VI, which was continuously cored down to 1176 meters at Site 370 and below 1176 meters at Site 416, is a sequence of brown and green-gray distal turbidites, in which sand and silt layers are more abundant and are more regularly spaced than in unit V. The lower boundary is marked by the appearance at Core 416A-36-3 of hard, pale-brown, micritic limestone above graded sand layers, and by red mudstone interbeds between graded cycles. The unit is not formally subdivided, although there are some significant differences between Core $416 \mathrm{~A}-8$, which is almost devoid of sand or silt, and Core 416A-9, which is about 33 per cent sand and silt in layers as much as $20 \mathrm{~cm}$ thick. A few conglomerate layers occur high in unit VI, both at Site 416 (Figure 12) and at Site 370. From Core 9 downward, a bed-by-bed record was kept of the continuously cored section.

Below 1176 meters, unit VI comprises 2377 (!) counted repetitions and partial repetitions of various gradational turbidite cycles. These progressively change in character through the unit. In the upper part, the full cycle (Figures 13 and 14) is as follows (from bottom to top):

(1) light-gray, well-indurated, quartzose sandstone with ripple cross lamination, convolute lamination, and parallel lamination (Bouma C, with some B); (2) medium-gray (N6), parallel-laminated siltstone with silty quartzose mudstone (Bouma D); (3) grayish-olive to grayish-olive-green (10Y $4 / 2$ to $5 \mathrm{GY} 3 / 2$ ) calcareous mudstone and marlstone; (4) pale-green to gray-green (10G 6/2 to $5 \mathrm{G} 6 / 1$ ) marlstone and claystone (Bouma E with unit 3).

In the lower part of unit VI, two distinct cycles can be recognized, one calcareous (gray green), the other quartzose (brown), (Figure 13). The green cycle begins with gray to greenish-gray (N6 to 5GY 6/1) calcarenite and calcisiltite with parallel and cross lamination (B, C, and
D). These grade upward into grayish-green to greenishgray (10GY $5 / 2$ to $5 \mathrm{G} 6 / 1$ ) nannofossil marlstone and calcareous mudstone, which give way in turn to grayishgreen $(5 G 5 / 2)$ nannofossil marlstone or claystone. The brown cycle starts with generally finer-grained, paralleland cross-laminated, quartzose sandstone and siltstone, grading through brownish-gray to grayish-brown (5YR $4 / 1$ to $3 / 2$ ) quartzose mudstone to grayish-red (10R 4/2) zeolitic claystone.

These two cycles which occur interbedded with one another (Figures 15 and 16), are not mutually exclusive, and transitional and compound examples are present. However, most beds fall into one or the other of the two types. The existence of two separate cycles was first recorded in Core 416A-22, but the change is gradual, and accompanied by other changes. Other sedimentary structures include disturbed bedding (Figures 17 and 18) and a wide variety of burrows (Figure 19).

The sandstones of the brown cycles are composed mainly of quartz, along with one or two per cent feldspar, and accessory zircon, tourmaline, rutile, and sphene, which tend to be concentrated on certain cross laminae in the Bouma $\mathrm{C}$ division. Rare muscovite and chlorite occur, and in some samples there are a few grains of glauconite and of phosphatic fish debris (see Price, this volume). Secondary pyrite is common, especially along the laminae rich in heavy minerals (Figure 20). The cement in the quartz sandstones is very commonly luster mottled: very large $(5 \mathrm{~mm})$ calcite cement crystals enclose the smaller $\left(0.05 \_0.1 \mathrm{~mm}\right)$ quartz grains, which are heavily etched (Figure 21). The calcite cement is commonly ferroan.

In the green cycles, the sandstone is rich in calcareous grains, especially micritized shallow-water benthic foraminifers. Ooids, mollusk fragments, echinoderm ossi- 
TABLE 4

Calcium-Carbonate Determinations for Site 416

\begin{tabular}{|c|c|c|c|}
\hline \multirow[b]{2}{*}{$\begin{array}{c}\text { Sample } \\
\text { (interval in } \mathrm{cm} \text { ) }\end{array}$} & \multicolumn{3}{|c|}{$\mathrm{CaCO}_{3}(\%)$} \\
\hline & $\begin{array}{c}\text { Shipboard } \\
\text { Carbonate } \\
\text { Bomb }\end{array}$ & $\begin{array}{c}\text { DSDP } \\
\text { Leco } \\
\text { WR-12 }\end{array}$ & $\begin{array}{l}\text { Bernard } \\
\text { Calcimeter } \\
\text { (data of } \\
\text { M. Melguen) }\end{array}$ \\
\hline $416-1-1,31-33$ & & & 54.0 \\
\hline $1-1,56-58$ & & & 43.0 \\
\hline $1-1,108-110$ & & & 35.0 \\
\hline $1, \mathrm{CC}, 3-4$ & 52 & & \\
\hline $416 \mathrm{~A}-1-1,28-30$ & & & 73.0 \\
\hline $1-1,82-84$ & & & 70.0 \\
\hline $1-1,98-99$ & & & 30.5 \\
\hline $1-1,112-114$ & & & 58.0 \\
\hline $1-2,3-4$ & & & 79.0 \\
\hline $1-2,27-29$ & & & 23.5 \\
\hline $1, \mathrm{CC}, 1-2$ & & & 58.0 \\
\hline $2-1,35-37$ & & & 24.0 \\
\hline $2-1,145-147$ & & & 71.5 \\
\hline $2-1,148-149$ & 66 & & \\
\hline $2-2,12-13$ & 24 & & \\
\hline $2-2,87-89$ & & & 22.0 \\
\hline $2-2,91-93$ & & & 50.0 \\
\hline $2-2,94-95$ & & & 32.0 \\
\hline $2-2,99-100$ & & & 31.0 \\
\hline $2-2,101-103$ & & & 36.0 \\
\hline $2-2,126-127$ & & & 22.0 \\
\hline $2-3,58-60$ & & & 27.0 \\
\hline $2-4,46-48$ & & & 39.0 \\
\hline $2-4,53-54$ & & & 23.0 \\
\hline $\begin{array}{l}2-4,54-55 \\
2-4,55-57\end{array}$ & & & $\begin{array}{l}32.5 \\
32.0\end{array}$ \\
\hline $\begin{array}{l}2-4,55-57 \\
3-1,100-101\end{array}$ & 43 & & \\
\hline $\begin{array}{l}3-1,100-101 \\
3-1,103-104\end{array}$ & 34 & & \\
\hline & & & 10.0 \\
\hline $3-3,45-47$ & & & 20.5 \\
\hline $3-3,107-109$ & & & 21.5 \\
\hline $3-3,113-115$ & & & 21.5 \\
\hline $3, \mathrm{CC}, 11-13$ & & & 42.1 \\
\hline $3, \mathrm{CC}, 19-21$ & & & 29.4 \\
\hline $3, \mathrm{CC}, 21-22$ & & & 28.6 \\
\hline $4-1,20-21$ & 24 & & \\
\hline $5-1,22-23$ & 34 & & \\
\hline $5-1,26-28$ & & & 9.5 \\
\hline $6-1,60-62$ & & & 2.4 \\
\hline $\begin{array}{l}6-1,62-63 \\
6-1,82-83\end{array}$ & & & 2.4 \\
\hline $6-1,130-131$ & $10-17 ?$ & & \\
\hline $6-2,94-95$ & $10-17 ?$ & & \\
\hline $6-3,8-10$ & & & 2.4 \\
\hline $6-3,130-132$ & & & 2.4 \\
\hline $7-2,110-112$ & & & 12.0 \\
\hline $7-2,116-119$ & & & 9.6 \\
\hline $7-3,3-4$ & 9 & & \\
\hline $7-3,10-12$ & & & 33.6 \\
\hline $7-3,15-16$ & & & 33.6 \\
\hline $7-3,23-25$ & 14 & & \\
\hline $9-1,102-104$ & & & 8.0 \\
\hline $\begin{array}{l}9-1,107-108 \\
9-1,111-112\end{array}$ & & & $\overline{9.7}$ \\
\hline $9-2,5-6$ & & & 23.4 \\
\hline $9-3,7-8$ & & & 42.7 \\
\hline $9-3,9-10$ & & & 22.6 \\
\hline
\end{tabular}

TABLE 4 - Continued

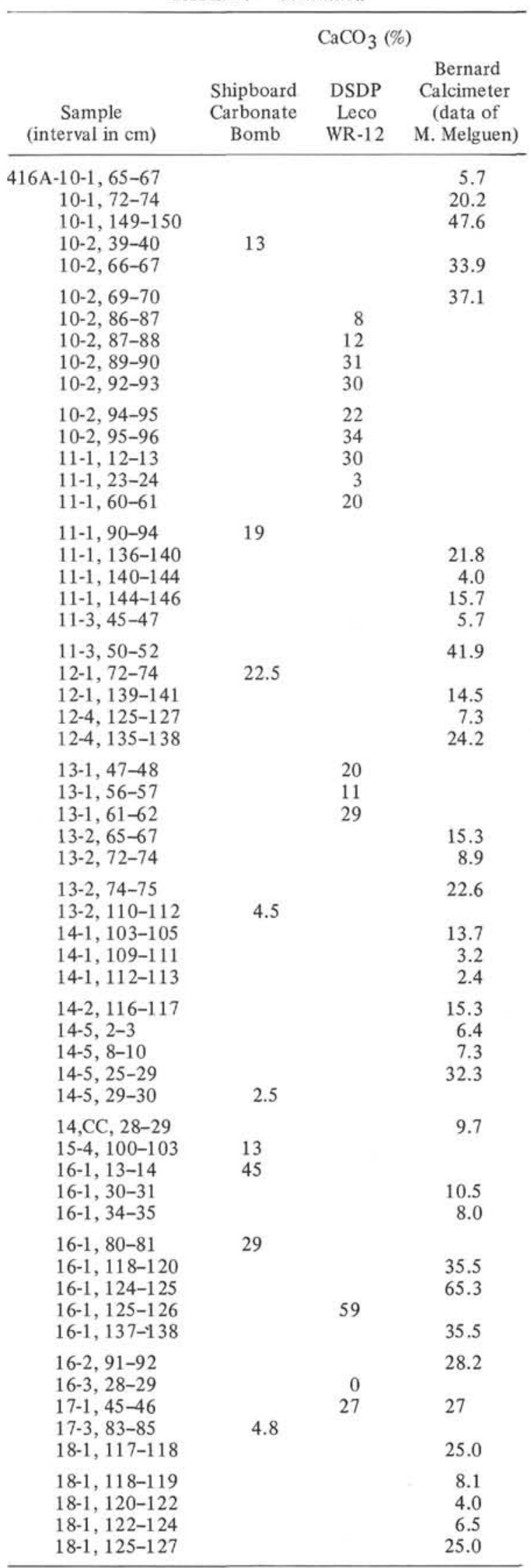


TABLE 4 - Continued

\begin{tabular}{|c|c|c|c|}
\hline \multirow[b]{2}{*}{$\begin{array}{c}\text { Sample } \\
\text { (interval in } \mathrm{cm} \text { ) }\end{array}$} & \multicolumn{3}{|c|}{$\mathrm{CaCO}_{3}(\%)$} \\
\hline & $\begin{array}{c}\text { Shipboard } \\
\text { Carbonate } \\
\text { Bomb }\end{array}$ & $\begin{array}{c}\text { DSDP } \\
\text { Leco } \\
\text { WR-12 }\end{array}$ & $\begin{array}{c}\text { Bernard } \\
\text { Calcimeter } \\
\text { (data of } \\
\text { M. Melguen) }\end{array}$ \\
\hline $\begin{array}{c}416 \mathrm{~A}-18-1,139-141 \\
18-4,96-98 \\
19-1,40-42 \\
19-1,46-47 \\
19-2,90-92\end{array}$ & 28 & & $\begin{array}{r}36.3 \\
\\
4.0 \\
10.5 \\
5.7\end{array}$ \\
\hline $\begin{array}{l}19-2,99-101 \\
19-2,107-109 \\
19-2,110-112 \\
19-5,63-64 \\
19-5,77-78\end{array}$ & & $\begin{array}{l}18 \\
47\end{array}$ & $\begin{array}{l}44.4 \\
55.6 \\
32.3\end{array}$ \\
\hline $\begin{array}{l}19-5,93-94 \\
19, \mathrm{CC}, 0-2 \\
20-1,94-96 \\
20-1,104-106 \\
20-1,105-107\end{array}$ & 18.5 & 4 & $\begin{array}{r}3.2 \\
9.7 \\
16.3\end{array}$ \\
\hline $\begin{array}{l}20-3,0-2 \\
20-3,20-22 \\
20-3,29-30 \\
20-3,70-72 \\
21-1,2-4\end{array}$ & 20.7 & & $\begin{array}{l}14.6 \\
23.6 \\
\\
52.0 \\
49.6\end{array}$ \\
\hline $\begin{array}{l}21-1,24-25 \\
21-1,26-28 \\
21-1,34-36 \\
21-1,80-81 \\
21-1,110-10\end{array}$ & & $\begin{array}{r}6 \\
15\end{array}$ & $\begin{array}{l}59.4 \\
41.4 \\
37.4\end{array}$ \\
\hline $\begin{array}{l}21-3,126-127 \\
21-4,82-84 \\
21-5,111-112 \\
23-2,11-13 \\
23-4,30-31\end{array}$ & 11 & $\begin{array}{r}5 \\
39 \\
47\end{array}$ & 39.0 \\
\hline $\begin{array}{l}23-4,61-62 \\
23-4,77-78 \\
25-1,82-84 \\
25-1,101-102 \\
25-1,105-106\end{array}$ & & $\begin{array}{l}10 \\
23\end{array}$ & $\begin{array}{l}3.3 \\
4.1 \\
3.3\end{array}$ \\
\hline $\begin{array}{l}25-1,112-113 \\
25-1,117-118 \\
25-2,20-21 \\
25-2,40-41 \\
25-3,36-37\end{array}$ & & $\begin{array}{r}9 \\
17 \\
54\end{array}$ & $\begin{array}{l}40.7 \\
33.3\end{array}$ \\
\hline $\begin{array}{l}27-1,121-122 \\
27-2,69-70 \\
27-3,106-107 \\
27-4,109-111 \\
28-2,76-77\end{array}$ & & $\begin{array}{r}2 \\
27 \\
35 \\
50\end{array}$ & 17.1 \\
\hline $\begin{array}{l}28-4,27-28 \\
29-3,49-50 \\
29-4,120-121 \\
29-5,12-14 \\
29-5,25-27\end{array}$ & & $\begin{array}{r}5 \\
64 \\
13\end{array}$ & $\begin{array}{l}4.9 \\
8.9\end{array}$ \\
\hline $\begin{array}{l}30-1,118-120 \\
30-3,57-60 \\
30-3,130-131 \\
30-3,138-139 \\
30-3,139-141\end{array}$ & 50.5 & & $\begin{array}{r}4.1 \\
36.6 \\
38.2 \\
35.0\end{array}$ \\
\hline $\begin{array}{l}30-5,69-70 \\
30-5,70-71 \\
34-2,97-98 \\
34-2,100-101\end{array}$ & $\begin{array}{l}3.5 \\
6 .\end{array}$ & & $\begin{array}{l}48.0 \\
40.7\end{array}$ \\
\hline
\end{tabular}

TABLE 4 - Continued

\begin{tabular}{|c|c|c|c|}
\hline \multirow[b]{2}{*}{$\begin{array}{c}\text { Sample } \\
\text { (interval in } \mathrm{cm} \text { ) }\end{array}$} & \multicolumn{3}{|c|}{$\mathrm{CaCO}_{3}(\%)$} \\
\hline & $\begin{array}{c}\text { Shipboard } \\
\text { Carbonate } \\
\text { Bomb }\end{array}$ & $\begin{array}{c}\text { DSDP } \\
\text { Leco } \\
\text { WR-12 }\end{array}$ & $\begin{array}{l}\text { Bernard } \\
\text { Calcimeter } \\
\text { (data of } \\
\text { M. Melguen) }\end{array}$ \\
\hline $\begin{array}{c}416 \mathrm{~A}-35-1,36-37 \\
35-1,74-75 \\
35-2,113-115 \\
35-2,119-121 \\
36-3,4-6\end{array}$ & $\begin{array}{l}12.3 \\
17.7\end{array}$ & $\begin{array}{r}64 \\
5\end{array}$ & 48.0 \\
\hline $\begin{array}{l}36-3,12-14 \\
36-3,33-34 \\
37-1,7-8 \\
37-2,33-34 \\
37-2,37-38\end{array}$ & 5 & 37 & $\begin{array}{l}57.7 \\
\\
50.4 \\
47.1\end{array}$ \\
\hline $\begin{array}{l}37-2,51-53 \\
37-3,86-87 \\
37-3,88-89 \\
37-4,6-7 \\
38-1,22-24\end{array}$ & & & $\begin{array}{r}8.1 \\
27.6 \\
20.3 \\
6.5 \\
11.4\end{array}$ \\
\hline $\begin{array}{l}38-1,34-35 \\
38-1,56-57 \\
38-1,108-109 \\
38, C C, 0-1 \\
42-3,13-14\end{array}$ & & $\begin{array}{r}63 \\
20 \\
\\
55 \\
9\end{array}$ & 7.3 \\
\hline $\begin{array}{l}43-1,42-44 \\
43-2,1-3 \\
43-3,149-151 \\
43, C C \\
44-1,62-63\end{array}$ & & 7 & $\begin{array}{r}4.1 \\
62.6 \\
16.3 \\
15.5\end{array}$ \\
\hline $\begin{array}{l}44-1,134-138 \\
45-1,100-101 \\
45-2,112-113 \\
46-4,36-37 \\
46-4,42-44\end{array}$ & & $\begin{array}{l}12 \\
65\end{array}$ & $\begin{array}{r}8.2 \\
17.9\end{array}$ \\
\hline $\begin{array}{l}46-4,49-50 \\
47-2,99-100 \\
48-1,85-88 \\
48-1,93-95 \\
48-2,7-8\end{array}$ & & 12 & $\begin{array}{r}29.3 \\
37.4 \\
4.1\end{array}$ \\
\hline $\begin{array}{l}50-2,0-2 \\
50-2,14-15 \\
50-2,102-104 \\
50-2,117-118 \\
52-1,56-57\end{array}$ & & 90 & $\begin{array}{r}3.3 \\
\\
24.4 \\
78.9\end{array}$ \\
\hline $\begin{array}{l}53-2,41-45 \\
53-2,139-141 \\
54-2,17-18 \\
54, C C, 17-18 \\
57-1,109-110\end{array}$ & $\begin{array}{l}38 \\
44\end{array}$ & & $\begin{array}{l}4.9 \\
6.5\end{array}$ \\
\hline
\end{tabular}

cles, aptychi, and micritic carbonate lumps, some containing calpionellids, are common. Glauconite and amber-colored phosphatic fish debris are generally present. The quartz content varies from 90 to 20 per cent. The tendency for luster-mottled calcite cement diminishes as the content of calcareous framework grains increases.

The clayey parts of both the brown and green cycles consist of a mixture of abundant illite and lesser smectite, with minor amounts of kaolinite, chlorite, and mixed-layer clays. The mudstones contain silt-size detrital quartz, micas, plant debris, and secondary pyrite.

The upper parts of the green cycles are commonly rich in carbonate; some beds top out in limestone. These 


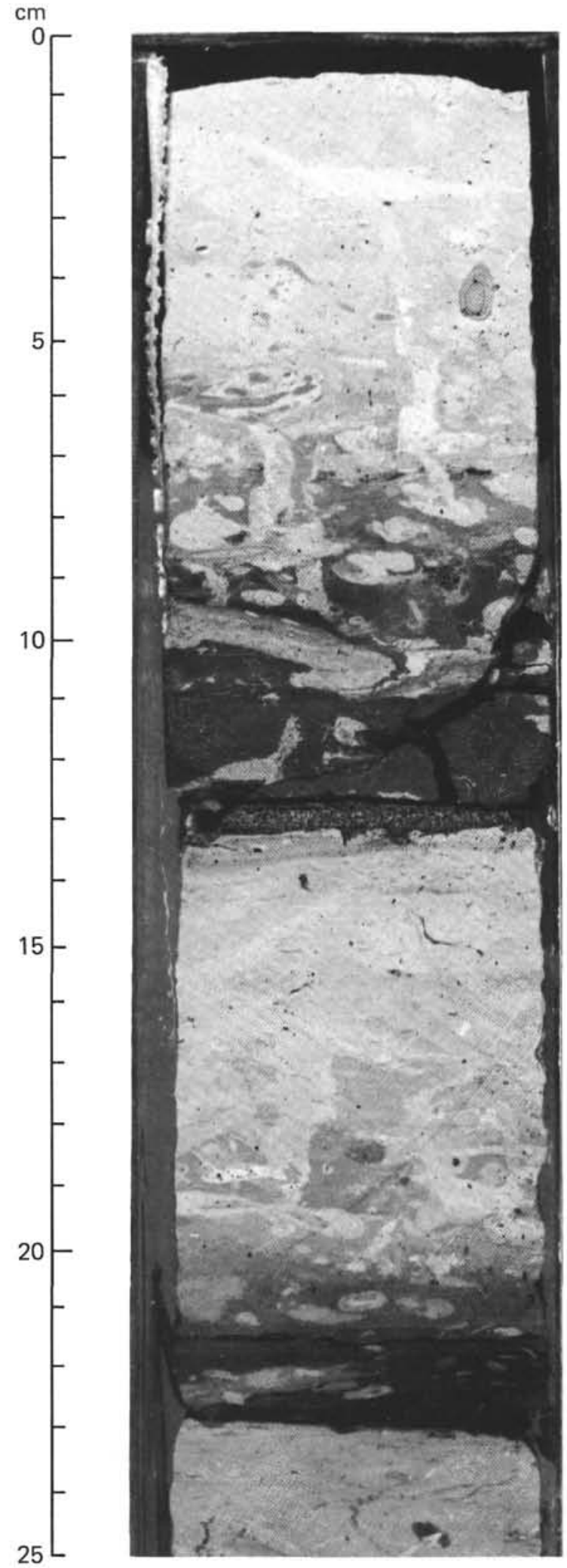

Figure 8. 416A-2-2, 0-25 cm. Two turbidite cycles, showing dark-colored, silty (at $23 \mathrm{~cm})$ or sandy (at 13 $\mathrm{cm}$ ) basal part of cycle, grading upward to lightercolored, more-calcareous and pelagic material. Burrows are nearly absent in the basal part of the cycle, but virtually homogenize the upper part.
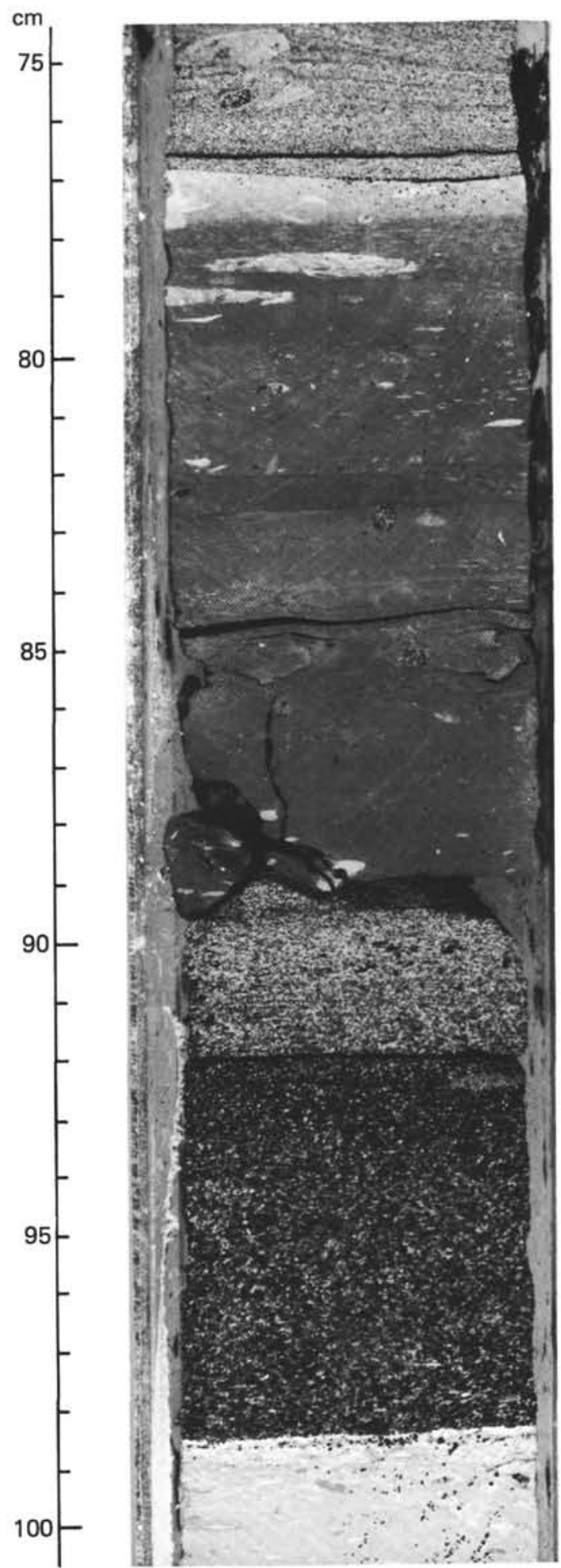

Figure 9. 416A-2-2, 75-100 cm. A turbidite cycle, consisting of a basal sand layer, beginning at $98.5 \mathrm{~cm}$ at an abrupt contact with burrowed nannofossil marl below, grading upward at $92 \mathrm{~cm}$ to slightly laminated sandstone, then at $89 \mathrm{~cm}$ into faintly laminated marlstone with small burrow mottles which become more numerous upward, then at $78 \mathrm{~cm}$ into lightcolored, marly nannofossil chalk. At $87 \mathrm{~cm}$ is the sandy base of the next, overlying cycle. Dark sand grains were artifically smeared below the contact during cutting of the core. 

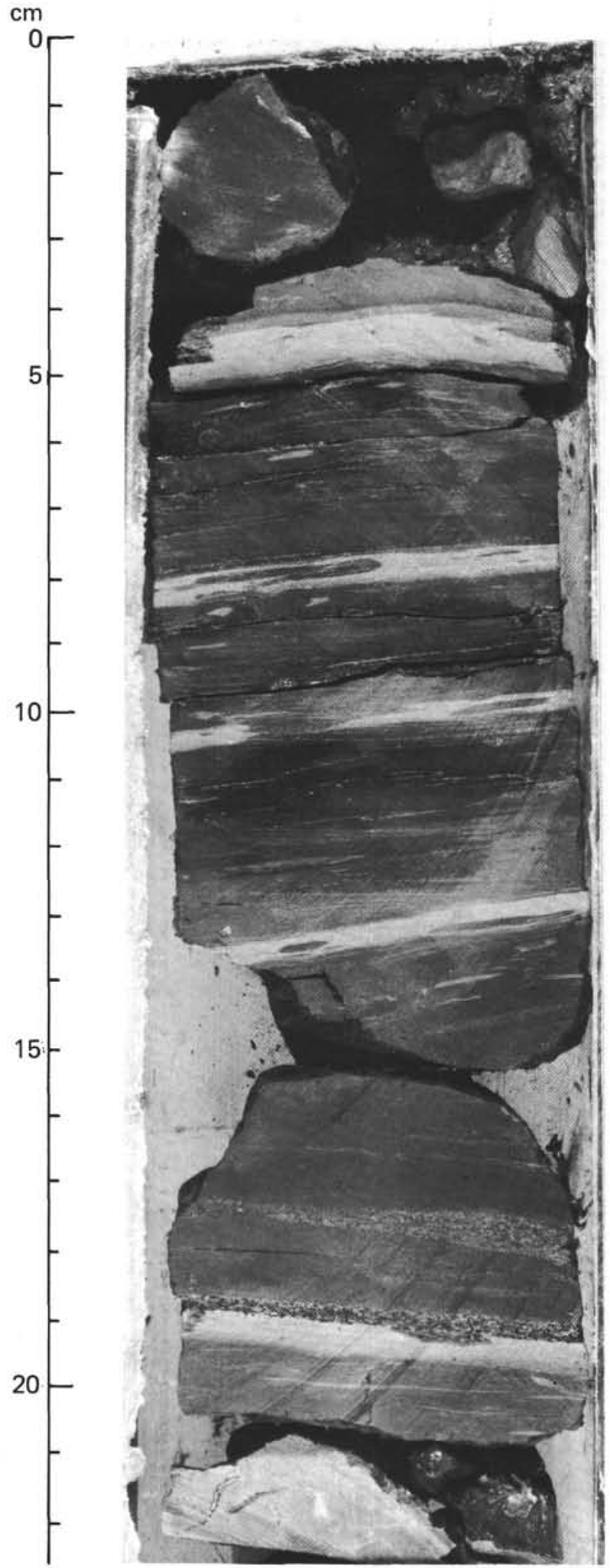

Figure 10. 416A-5-1, 0-20 cm. Graded and laminated sequences of olive-gray, quartzose, silty sandstone, (light-colored bands) and greenish-gray dolomite, mudstone, and marlstone (dark-colored bands). The dark-colored sandstone layer at $19 \mathrm{~cm}$ contains abundant mudstone clasts and glauconite grains. Burrow mottles are flattened by compaction.
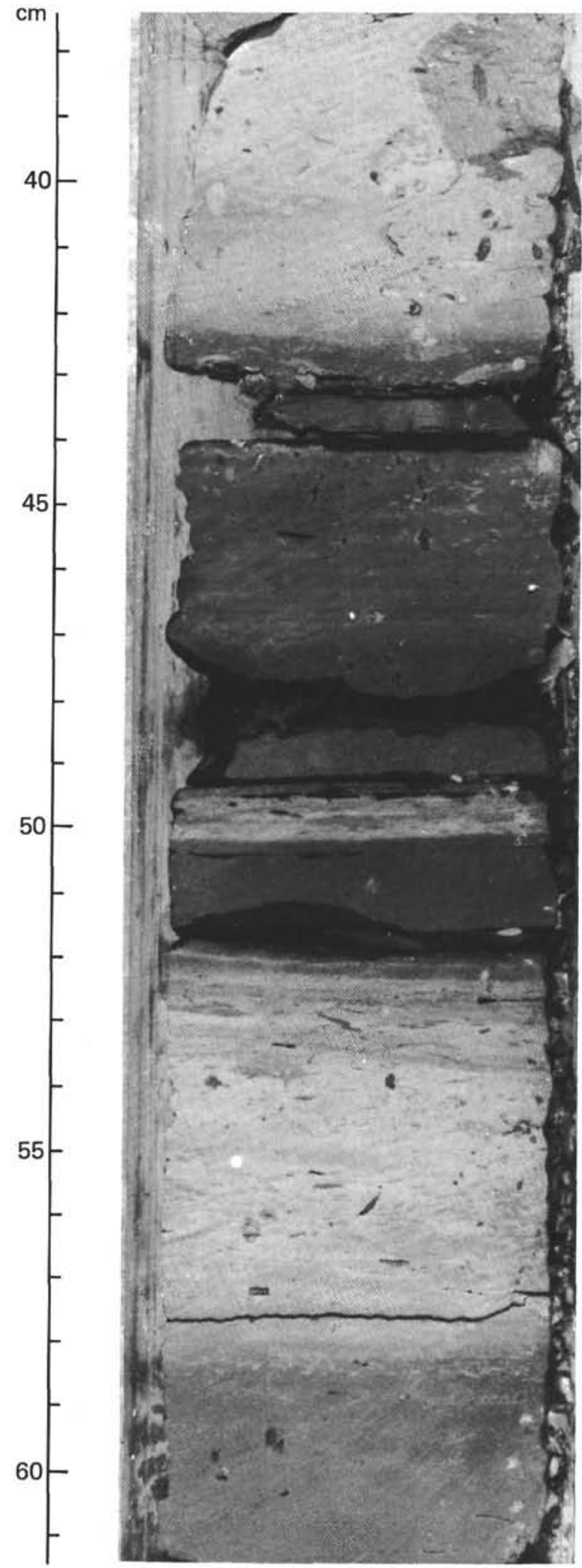

Figure 11. 416A-6-3, 40-60 cm. Intensively burrowmottled, blue-green mudstone $(58-52 \mathrm{~cm})$ and oliveblack mudstone $(52-50 \mathrm{~cm})$, overlain by a graded sequence, beginning at $50 \mathrm{~cm}$ with a thin layer of silty sandstone and grading upward to olive-black mudstone with abundant chondrites $(49-53 \mathrm{~cm})$ and bluegreen, burrow-mottled mudstone. 


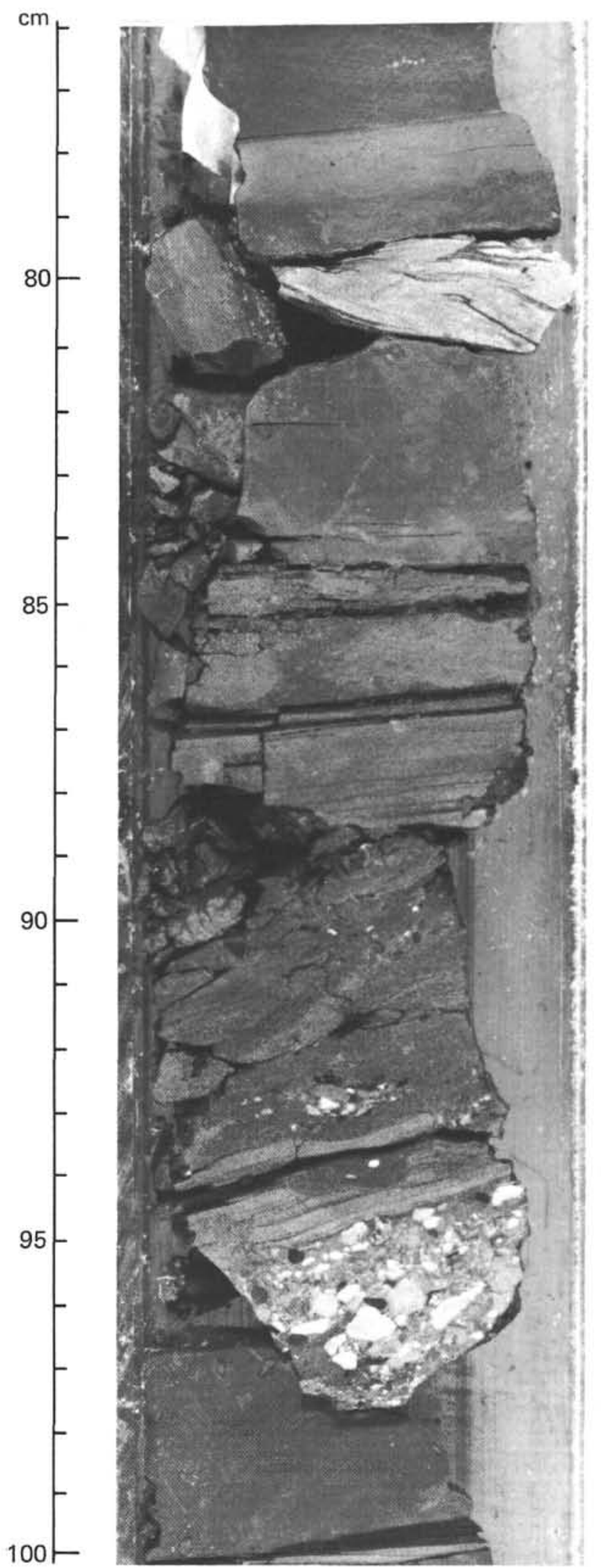

Figure 12. 416A-7-2, 83-100 cm. Basal part of a turbidite bed at least $15 \mathrm{~cm}$ thick, with conglomerate at the base. Several levels of pebbles and granules occur in the lower $70 \mathrm{~cm}$ of the bed. The clasts are calcarenite and fine-grained limestone.

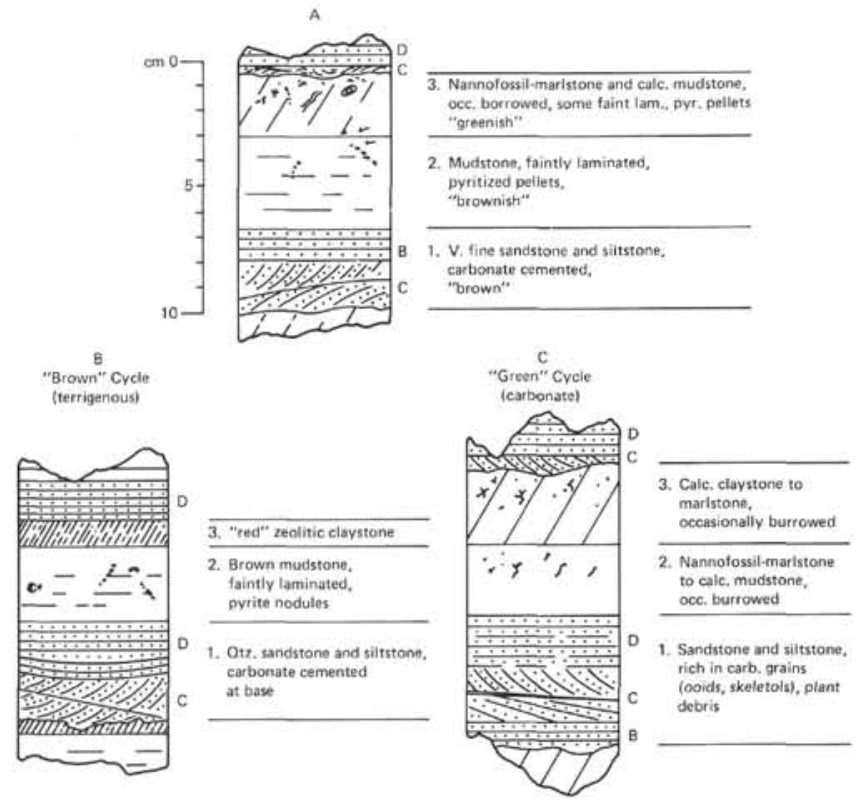

Figure 13. Typical turbidite cycles in Unit VI. A. This mixed terrigenous-carbonate cycle occurs from Core 416A-9 through Cores 416A-17 to 416A-20. It consists of (1) very fine sandstone and siltstone (pale brown to grayish brown), parallel and cross laminated, carbonate cemented; mainly Bouma units $C$ and $D$ beginning the cycle; (2) mudstone (grayish brown to dusky yellowish brown), faintly laminated with scattered pyritic pellets infilling burrows; and (3) nannofossil marlstone and calcareous mudstone (pale green, grayish green, olive gray) with burrows and pyritized pellets. From Cores $416 \mathrm{~A}-17$ to $416 \mathrm{~A}$ 20 through 416A-36, the compressional types of turbidites can be distinguished. B. Terrigenous (brown) cycle, consisting of (1) quartz sandstone and siltstone (pale brown), parallel and cross laminated, carbonate cemented at the base, with mica and plant debris; mainly Bouma units $C$ and D starting the cycle; (2) mudstone (brown to grayish brown), massive or faintly laminated, with pyrite nodules; and (3) zeolitic claystone (grayish red), often burrowed, at least partly perennial sediment. C. Carbonate (green cycle, consisting of (1) sandstone and siltstone (gray to greenish gray) rich in carbonate grains (ooids, skeletals), parallel and cross laminated; Bouma units $B, C$, and $D$ at the base; (2) nannofossil marlstone to calcareous mudstone (grayish green to greenish gray), occasionally burrowed; and (3) calcareous claystone to marlstone (grayish green), occasionally burrowed.

are generally rich in nannofossils, calcispheres, or calpionellids, along with silt-size detrital quartz, muscovite, and plant remains. Calcite-replaced radiolarians were noted in a few thin sections.

Although the primary depositional features of the turbidites of unit VI are very well preserved, alteration at and below the sea floor has left its vestiges:

1. Bottom currents seem occasionally to have removed the fine top of a graded bed, leaving a sand layer 


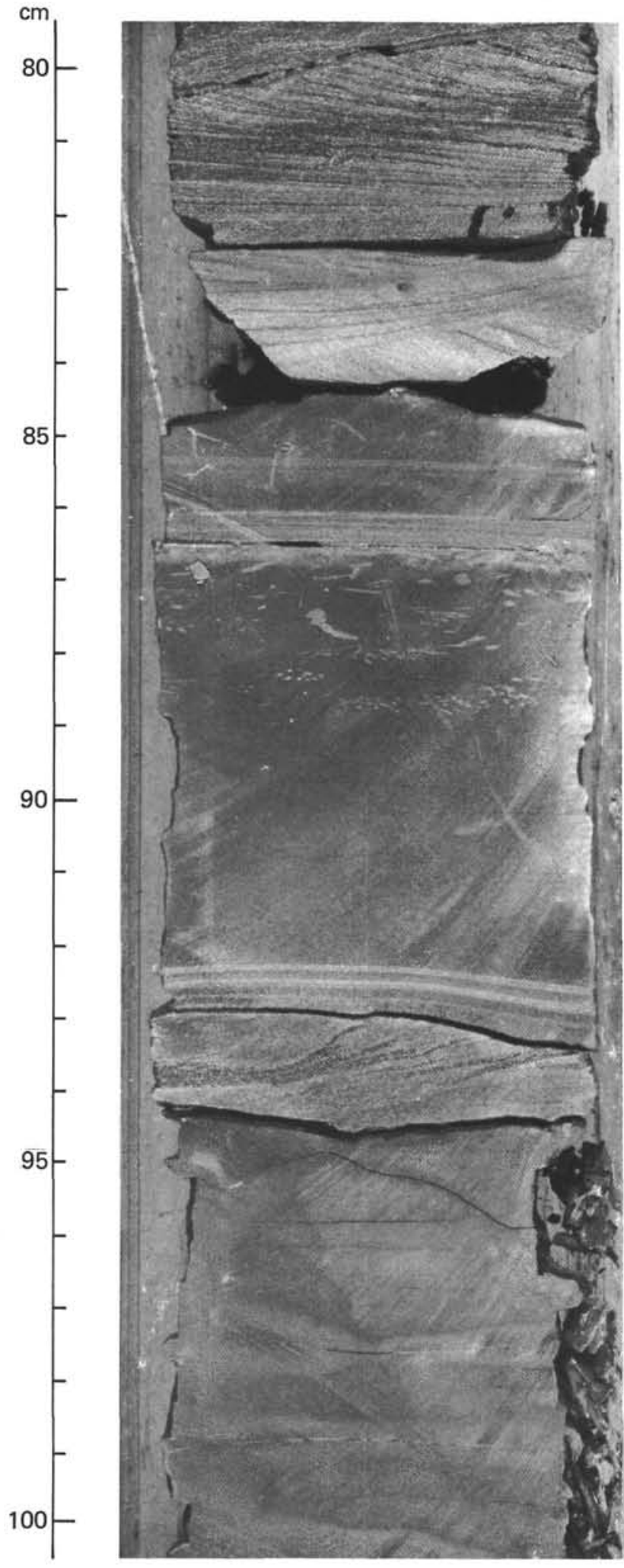

Figure 14. 416A-10-2, 80-100 cm. Typical turbidite cycles in the upper part of unit VI. Cycles begin at $104,94,87$, and $84 \mathrm{~cm}$. The cycle that begins at $94 \mathrm{~cm}$ is fully expressed, while the others show variations; the beds at 104 and $84 \mathrm{~cm}$ have a well-developed cross-stratified Bouma $C$ division, but lack the laminated Bouma D division; the bed at $87 \mathrm{~cm}$ begins with the Bouma D division.

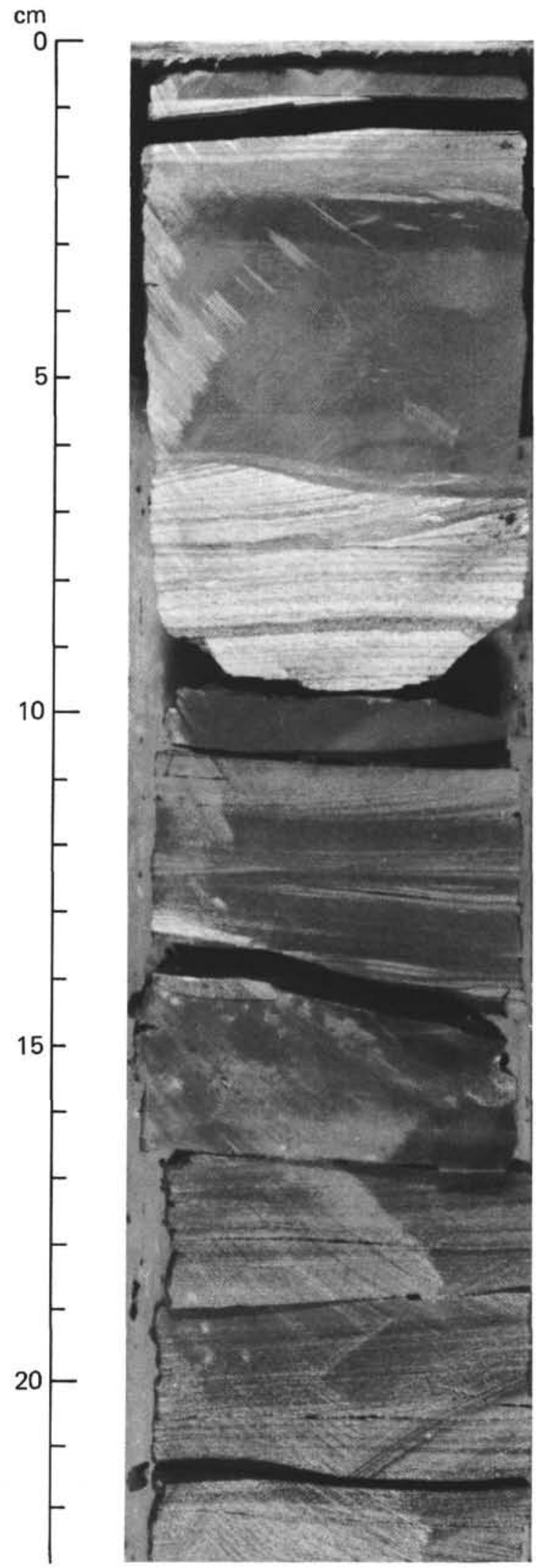

Figure 15. 416A-23-5, 0-20 cm. Two green cycles (2-9 $\mathrm{cm}, 9-14 \mathrm{~cm})$ overlying a brown cycle $(14-25 \mathrm{~cm})$. The upper green cycle is typical, but the lower green cycle is somewhat intermediate in character. 


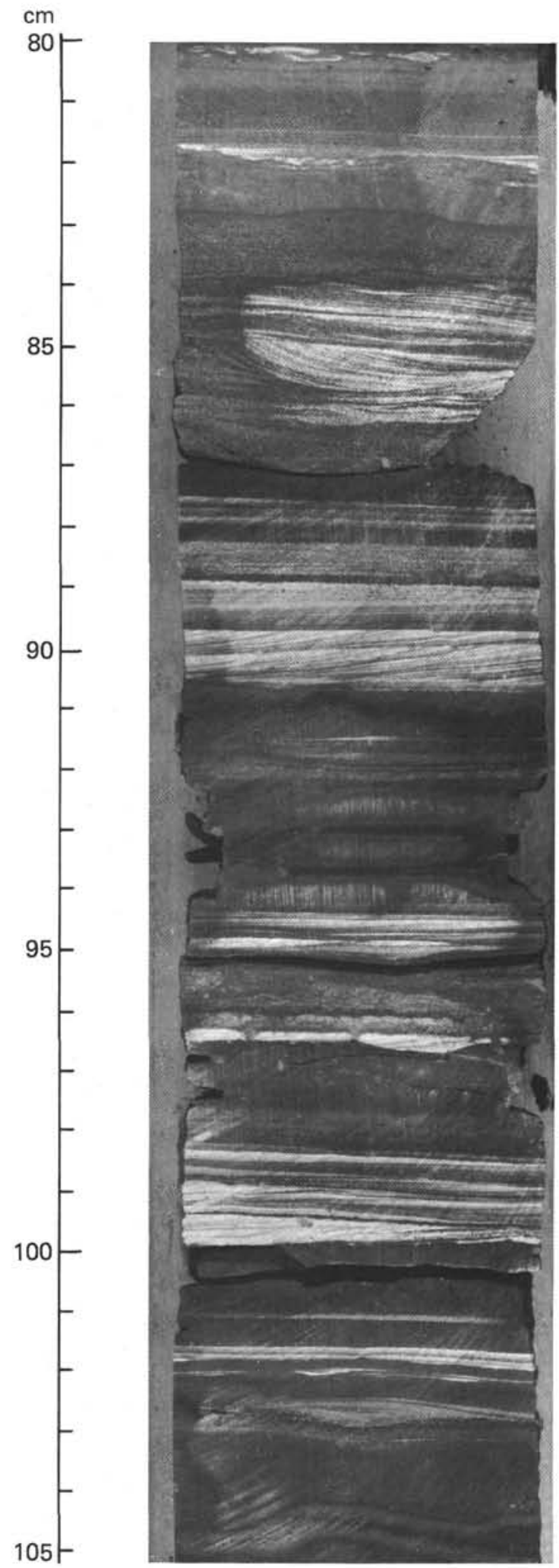

Figure 16. 416A-35-1, 80-105 cm. Typical interstratified green (light-colored sandstone) and brown (darker-colored sandstone) cycles. Most cycles are Bouma $C-D-E$ or $D-E$, but some sandy laminae (e.g., at $88 \mathrm{~cm}$ ) have sharp contacts with mudstone both above and below. The layer at $88.5 \mathrm{~cm}$ is very poorly sorted, muddy sandstone.

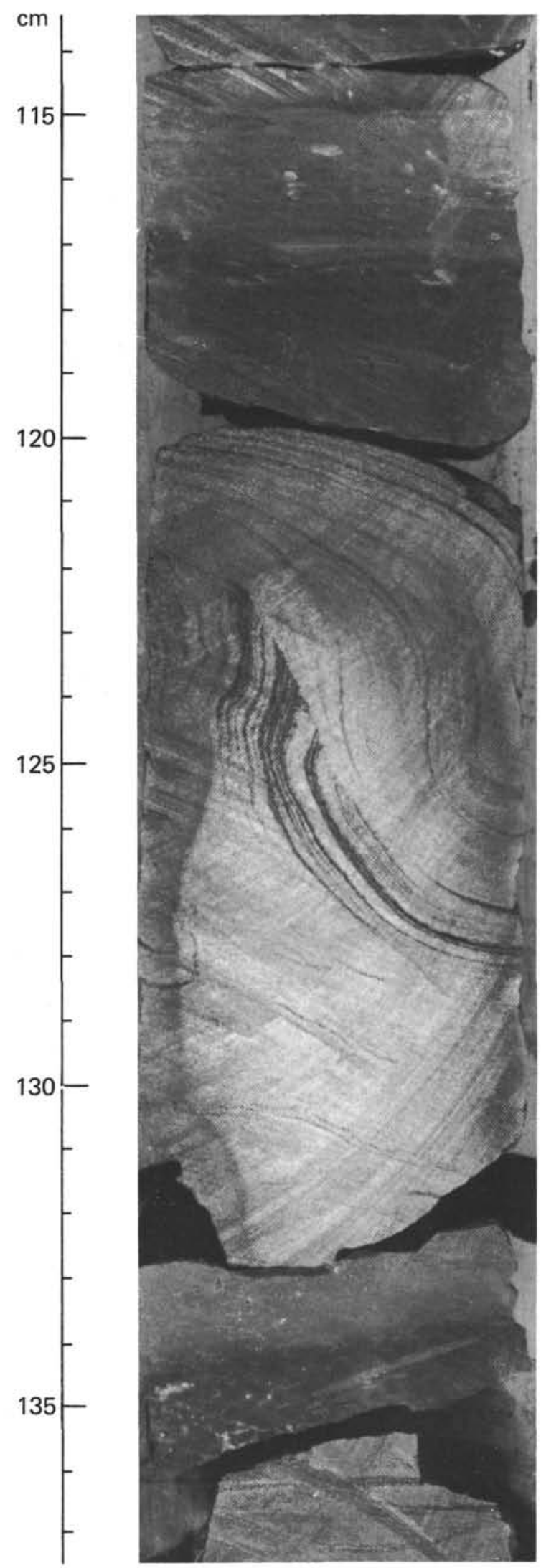

Figure 17. 416A-9-4, 115-135 cm. Disturbed bedding. The form of the disturbance - sub-horizontal at the base, steep in the middle, more horizontal at the top - suggests that this is convolute bedding. 


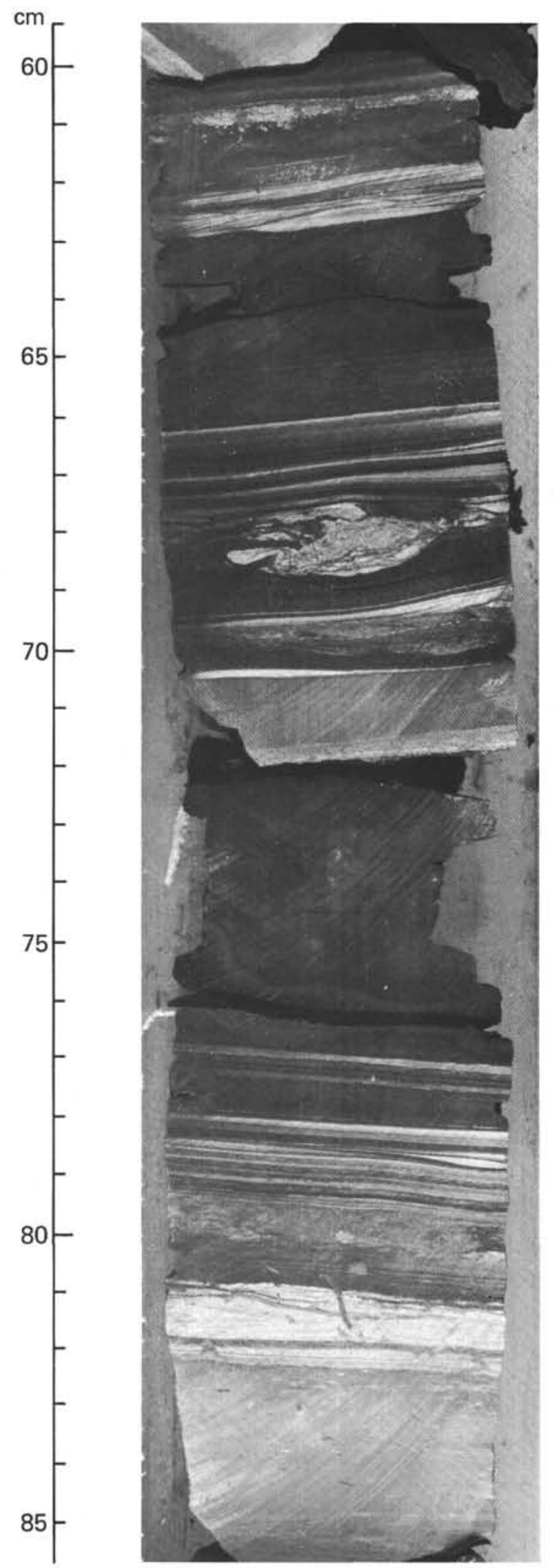

Figure 18. 416A-35-2, 60-85 cm. Disturbed bedding at $68 \mathrm{~cm}$. Probably a former load structure. Burrows that cut into the basal sand of a turbidite cycle occur at $81 \mathrm{~cm}$. Such sand-cutting burrows are rare in the Cretaceous at Site 416.

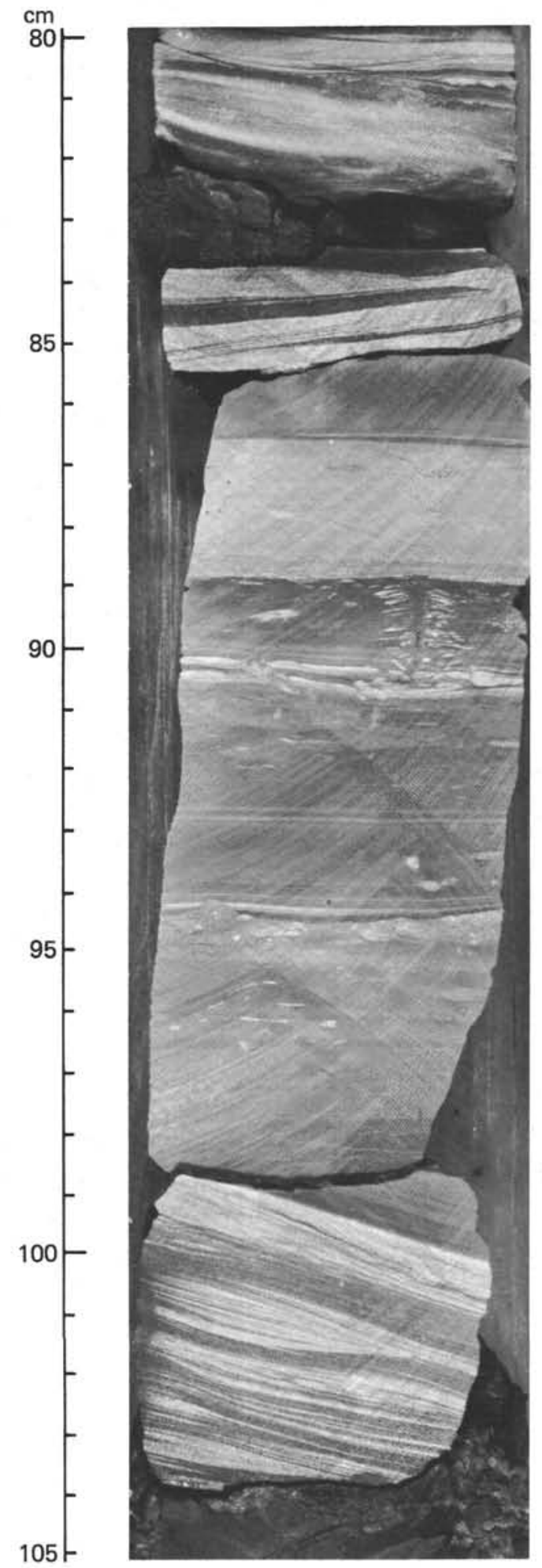

Figure 19. 416A-35-3, $80-105 \mathrm{~cm}$. A burrow at 89 to 91 $\mathrm{cm}$ shows sand lobes projecting from the central tube, which is partly filled with dark-colored secondary pyrite. Note the burrows at $90.5 \mathrm{~cm}$ that penetrate the sandy base of the turbidite layer. The cycle at 104 to $94 \mathrm{~cm}$ shows the typical distribution of burrows: numerous near the top of the cycle, fewer and fewer below, no burrows into the basal sandy part of the cycle. 


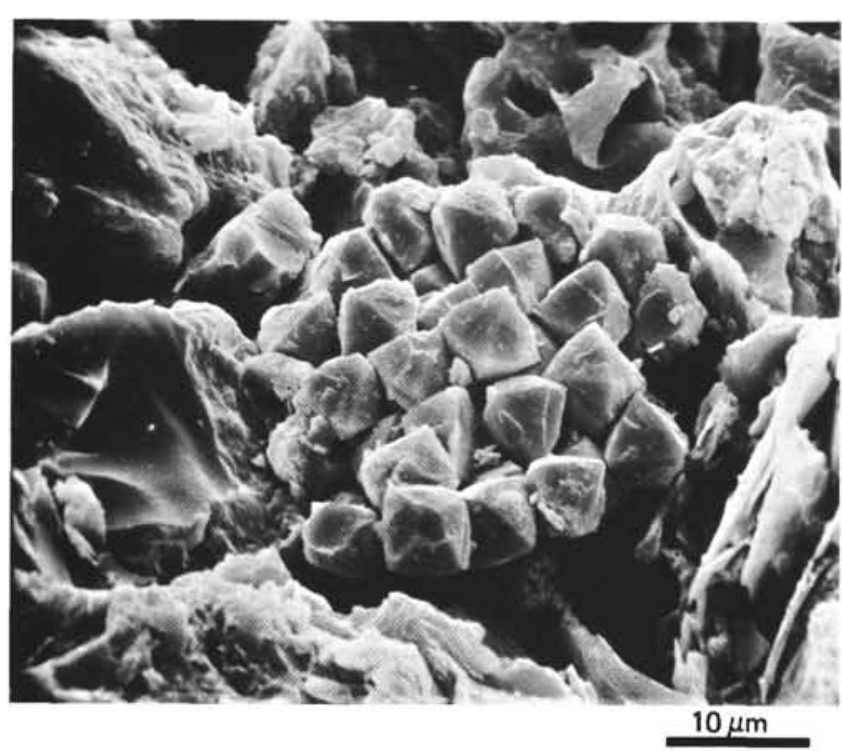

Figure 20. 416A-15-1, 25-28 cm. Scanning electron micrograph of a pyrite rosette in quartz sandstone. Acid-etched and gold-coated.

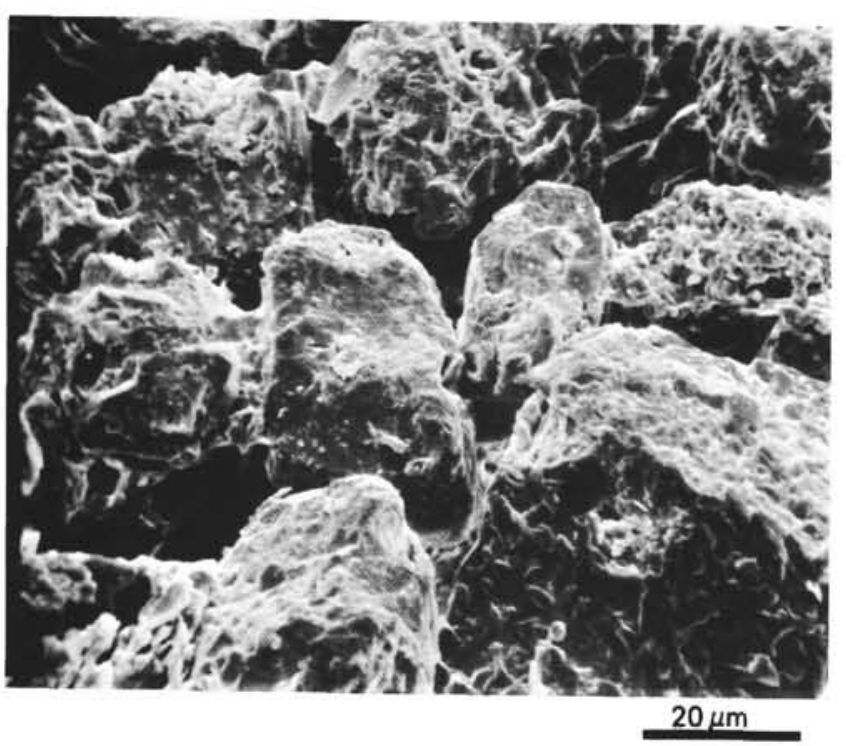

Figure 21. 416A-14-1, 40-49 cm. Scanning electron micrograph of quartz sandstone with luster-mottled calcite cement dissolved away to show deep etching (replacement) of quartz by calcite cement. Goldcoated.

with a sharp top, later covered by mud. Ungraded, silt-mud laminations with alternating parallel- and crosslaminated intervals may be the deposits of these bottom currents. Reworking and winnowing decrease upward in the section.

2. Bioturbation plays only a minor role. Most burrowing is in the top parts of the turbidites. Even there, it rarely leads to complete destruction of lamination. Sands are very rarely crossed by single burrows. Chondrites and Helminthoida are most common; Zoophycos appears occasionally below Core 416A-28.
3. Sea-floor dissolution of carbonate is probably the cause of a slight drop in carbonate content at the top of the carbonate turbidites.

4. Compaction and cementation have affected almost all sands after deposition. Long and concave-convex grain contacts dominate tangential contacts, and cemented pore space amounts to only 5 to 30 per cent, most commonly 10 to 20 per cent. In the calcarenites, compaction is enhanced by pressure solution along sutured grain contacts (not observed in quartz sands). Shells are cracked and bent around other grains. Following compaction, the quartz sands were cemented by ferroan calcite, ferroan dolomite, and possibly ankerite (all identified by staining). Calcite and ferroan calcite are found in the calcarenites. Cementation also affected the fine tails of the carbonate turbidites, producing marlstones. The cement probably was derived from aragonite and magnesian calcite swept in from shallowwater environments with the turbidity current.

Unit VII: Terrigenous and carbonate turbidites. Cores 416 A-36-3 to 54 ; 1430 to 1624 meters. Valanginian to Tithonian.

Unit VII differs from unit VI by the common occurrence of hard micritic limestones in the upper part of the calciturbidite beds and of lithoclasts of calpionellid limestone in their coarse basal parts.

The rocks are similar to those in the lower part of unit $\mathrm{V}$ and consist of alternations of terrigenous and carbonate-rich graded cycles (5-20 cm thick), with a very minor amount of silt-mud laminations and sand layers with sharp bases and tops. Red and brown colors dominate in both types of cycles, with additional gray and green colors mainly in the carbonate cycles.

A typical terrigenous cycle (Figure 22) consists of (bottom to top):

1. Quartz siltstone and fine sandstone (brown, 5YR $4 / 1$ to $5 / 2$; occasional grayish green $5 \mathrm{G} 4 / 1$ to $6 / 1$, parallel and cross-laminated (Figure 23); Bouma $C$ and D intervals. Heavy minerals and secondary pyrite are concentrated along some laminae (Figure 24). Plant remains are common (Figure 25), but these also occur in the calcareous cycle.

2. Brown mudstone (5YR 3/2-3), homogeneous or faintly laminated; occasional plant debris; traces of nannofossils.

3. Red zeolitic mudstone (5YR 3/3-4, occasionally altered diagenetically to green, $10 \mathrm{G} 6 / 2-5 \mathrm{G} 7 / 2$ ), faintly laminated or homogeneous, often burrowed; traces of nannofossils and crystalline carbonate.

A typical carbonate cycle (Figure 26) consists of (bottom to top):

1. Calcarenite, quartz-bearing. Main components are lithoclasts of micritic limestone (green, gray, or pink; some with calpionellids), skeletal fragments, aptychi, ostracodes, calcispheres, "rotaliid" foraminifers. Parallel and ripple cross-lamination (Bouma A, B, and C). Figures 27 through 30 show variations of the ideal sequence. Figures 31 and 32 show a calcarenite in thin section.

2. Micritic calcisiltite to quartz siltstone (colors similar to those of part 4), parallel- or cross-laminated 


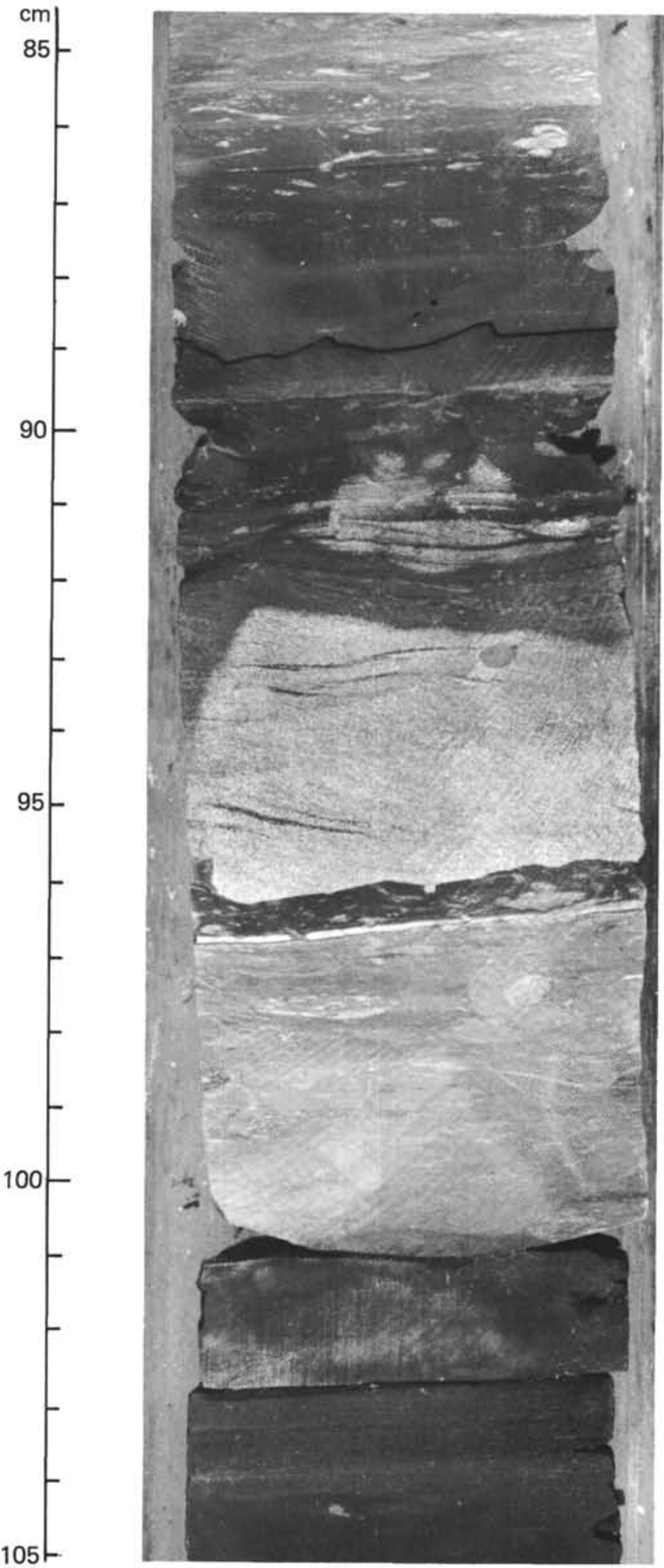

Figure 22. 416A-37-3, 85-105 cm. A terrigenous turbidite cycle in unit VII begins at $96 \mathrm{~cm}$ with crossstratified (Bouma division C) quartz sandstone on a sharp, channeled base. This passes upward into laminated siltstone, then into brown, burrowed mudstone. Reddish zeolitic mudstone occurs at the very top of the cycle, just beneath the thin, silty lamina at $89.5 \mathrm{~cm}$, which marks the base of the next cycle.

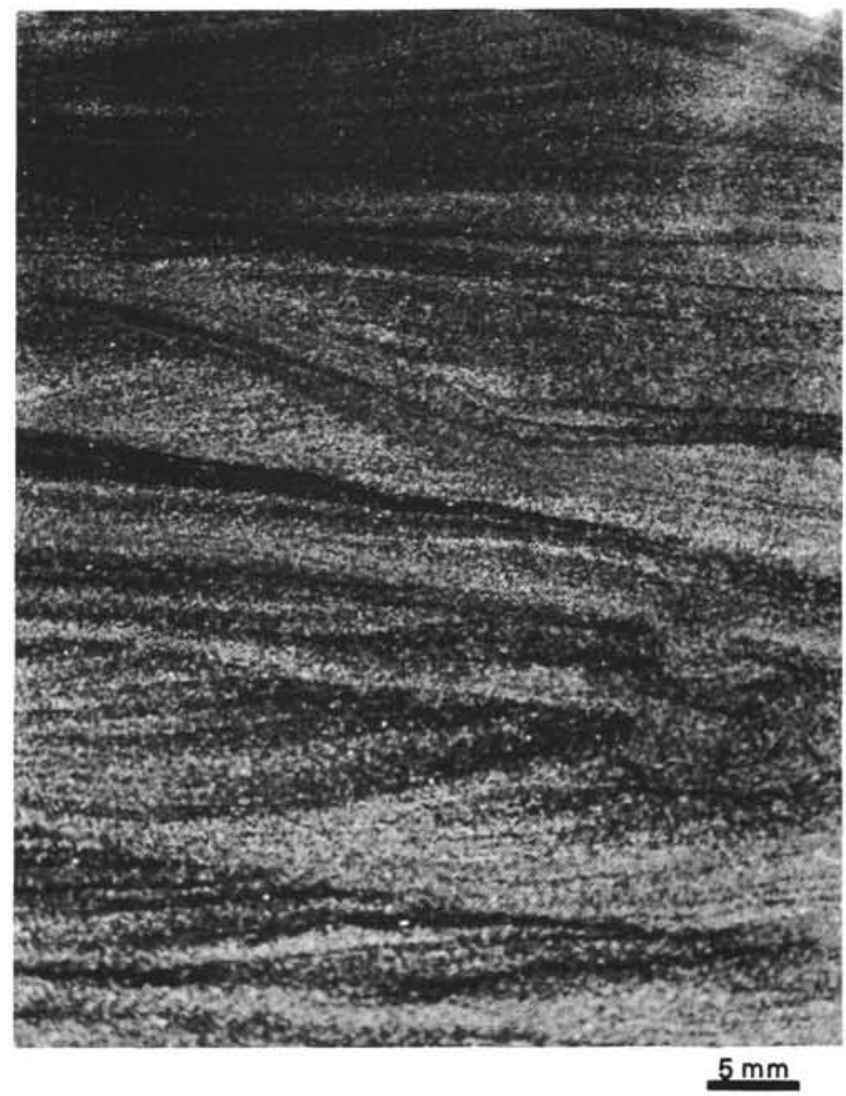

Figure 23. 416A-50-2, 108-115 cm. Photomicrograph of cross-stratified (Bouma division C) sandstone near the base of a calcareous-turbidite unit. Some of the laminae are quartz-rich, with dark-colored, clayey flakes; others are rich in redeposited calcareous material, including dark-colored micrite grains.

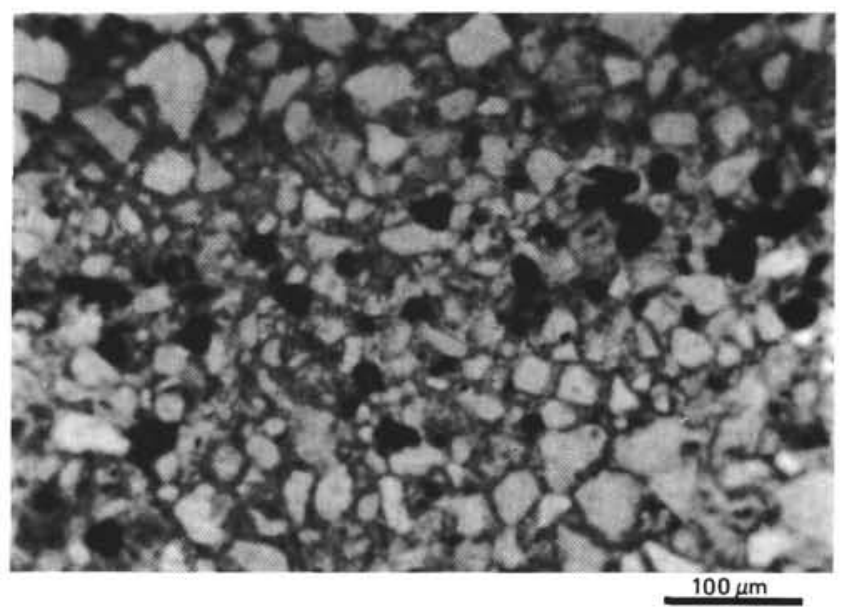

Figure 24. 416A-53-1, 5-7 cm. Photomicrograph of a heavy-mineral cross-lamina in calcite-cemented quartzose sandstone, with secondary pyrite (black) grains concentrated along the lamina. 


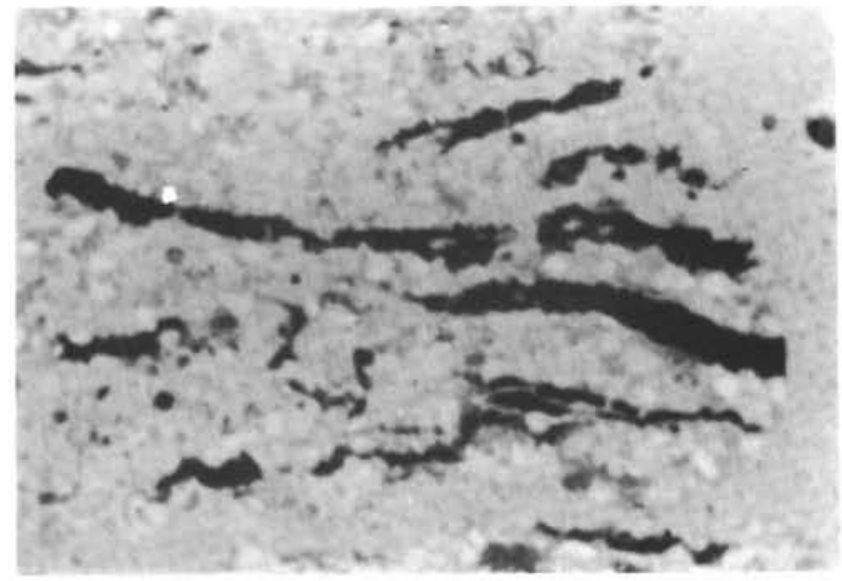

Figure 25. 416A-52-1, 70-74 cm. Plant debris in quartzose sandstone turbidite.

(Bouma C or D). Skeletal debris, particularly thin shells and calpionellids, hydraulically sorted in layers.

3. Dark-gray marlstone $(5 \mathrm{G} 24 / 1)$, rich in dolomite(?) rhombs and rather well-preserved nannofossils, laminated.

4. Micritic limestone with some marlstone, pinkish gray $(5 Y R 8 / 1)$ to gray (N7) to olive gray (5Y 6/1), laminated, often burrowed from top.

Apart from their composition, the two types of turbidites differ in several other aspects, as shown below:

\begin{tabular}{lll}
\hline Basal Bouma number & \multicolumn{1}{c}{$\begin{array}{c}\text { Terrigenous } \\
\text { Mostly C, some D, rare E }\end{array}$} & $\begin{array}{c}\text { Carbonate } \\
\text { A, B, C, rare D }\end{array}$ \\
\hline Grain size at base & $\begin{array}{l}\text { Very constant, mostly } \\
\text { very fine sand to silt }\end{array}$ & $\begin{array}{l}\text { Highly variable: } \\
\text { silt to coarse } \\
\text { sand }\end{array}$ \\
Bed thickness & Very constant, 5-10 cm & $\begin{array}{l}\text { Highly variable: } \\
\text { few cm to } \\
30 \mathrm{~cm}\end{array}$ \\
\hline
\end{tabular}

Graded beds displaying the upper part of the Bouma sequence are the most common forms. However, approximately one out of five sand layers has a sharp top boundary and is abruptly overlain by mudstone. These may represent turbidites that were partly eroded by bottom currents. The material removed by these currents may have been deposited in silt-mud laminations that occur between the graded beds. They are either not graded at all or inversely graded and leave gradational basal and top boundaries. Burrowing is intense in certain units (Figure 33).

Clay minerals of unit VII are dominated by illite and smectite. Chlorite, irregular mixed-layer clays, and kaolinite are also present.

\section{Diagenesis}

Diagenetic patterns in unit VII differ slightly from those in unit $\mathrm{V}$.

The terrigenous sandstones are tightly packed, like those in unit V, but are cemented mainly by ferroan calcite. Ferroan dolomite is scarce in the sandstones, with the exception of the two thick, gray sandstone beds in

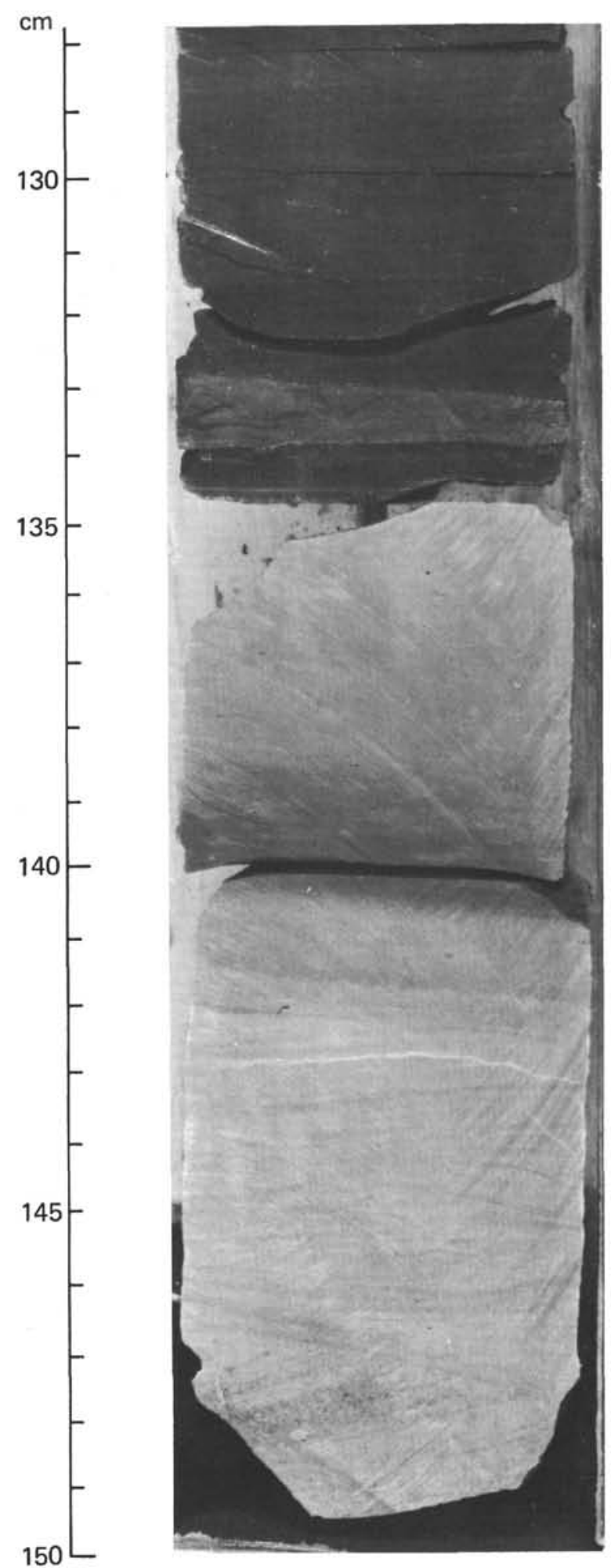

Figure 26. 416A-57-1, 130-150 cm. A typical, almost ideal calcareous turbidite cycle in unit VII: crossstratified calcarenite at the base, grading up into laminated calcisiltite, then into darker-colored, burrowed marlstone, and then into light-colored, micritic limestone. All parts are detrital: the calpionellid fragments become smaller and smaller near the top of the bed. 


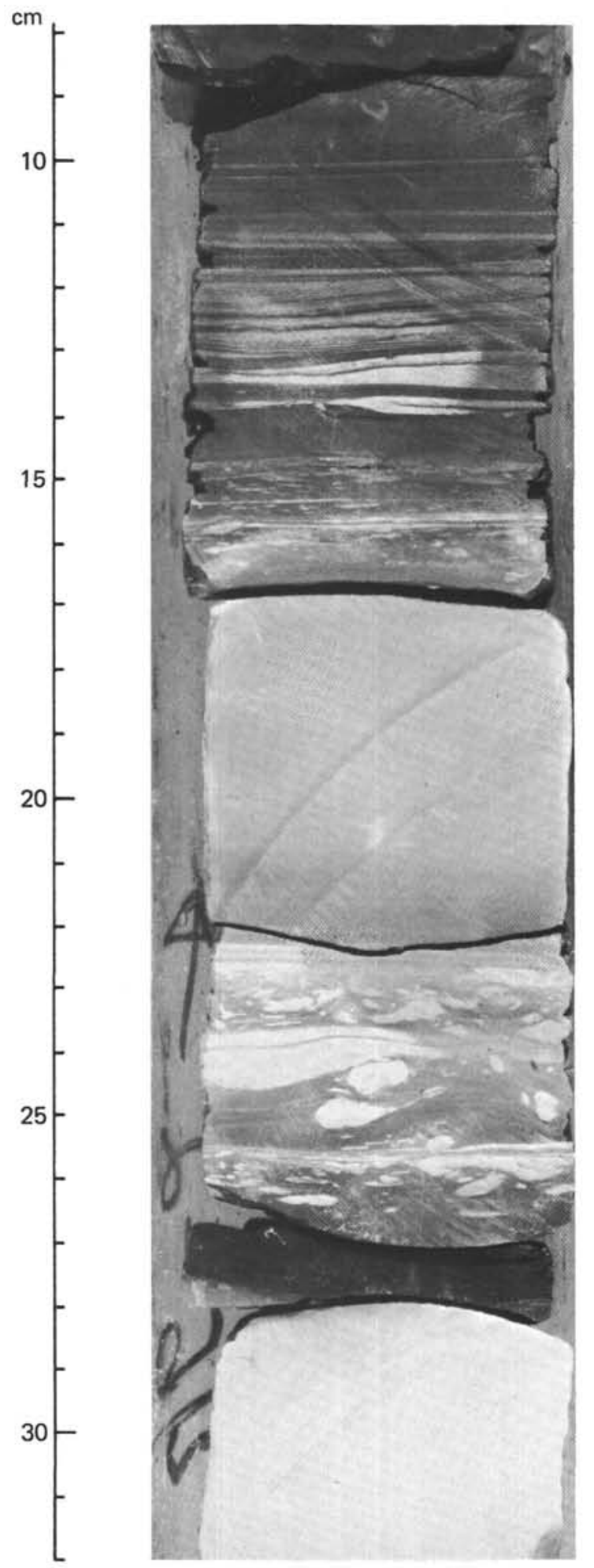

Figure 27. $416 A-46-2,10-30 \mathrm{~cm}$. From 22.5 to $17 \mathrm{~cm}$ is a calcareous-turbidite cycle, beginning with laminated, silty sandstone of Bouma division $D$. The underlying greenish marlstone is intensively burrowed.
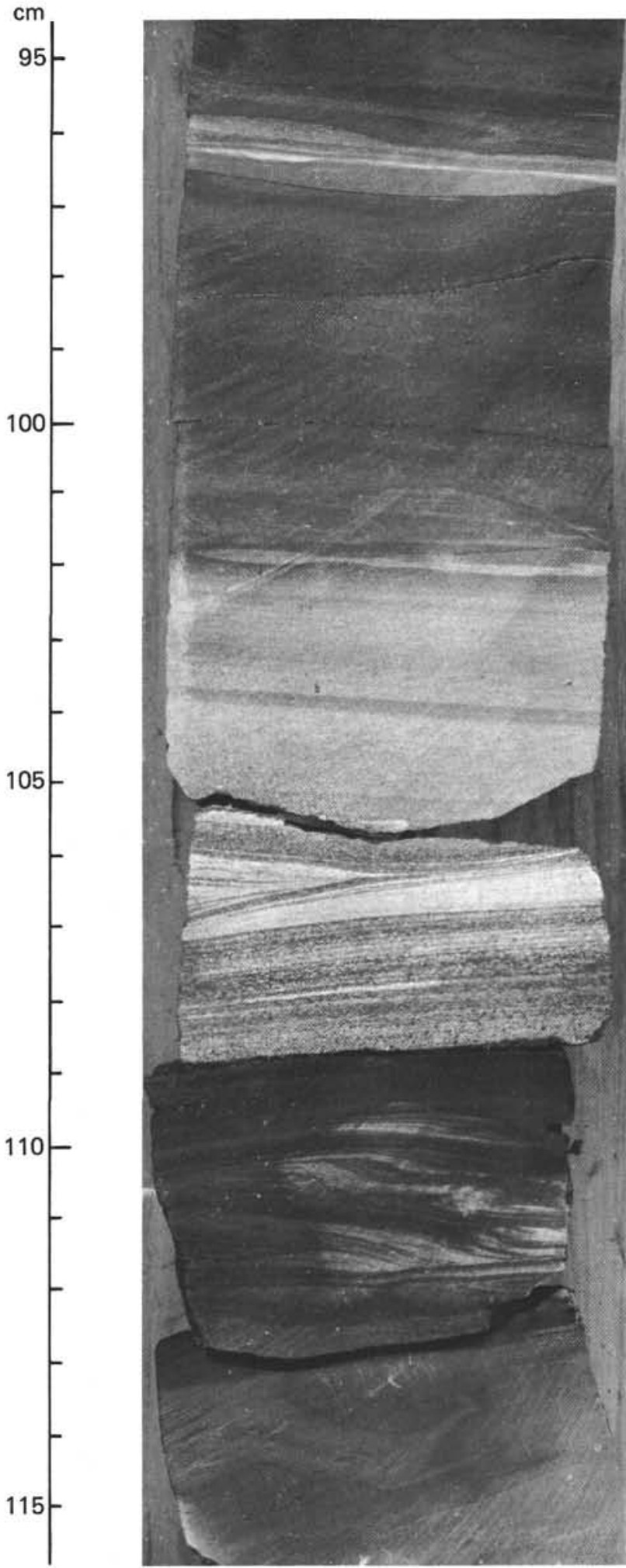

Figure 28. 416A-37-2, 95-115 cm. Calcareous turbidite cycle from 109 to $97 \mathrm{~cm}$, beginning with cross-stratified calcarenite of Bouma division $C$, with abundant micrite grains, redeposited calpionellid-limestone grains, calcipheres, thin-shelled mollusks, and quartz. The sediments are slightly more marly upward, but most of the change is simply a decrease in grain size. A few secondary-dolomite rhombs occur in the upper part of the bed. 

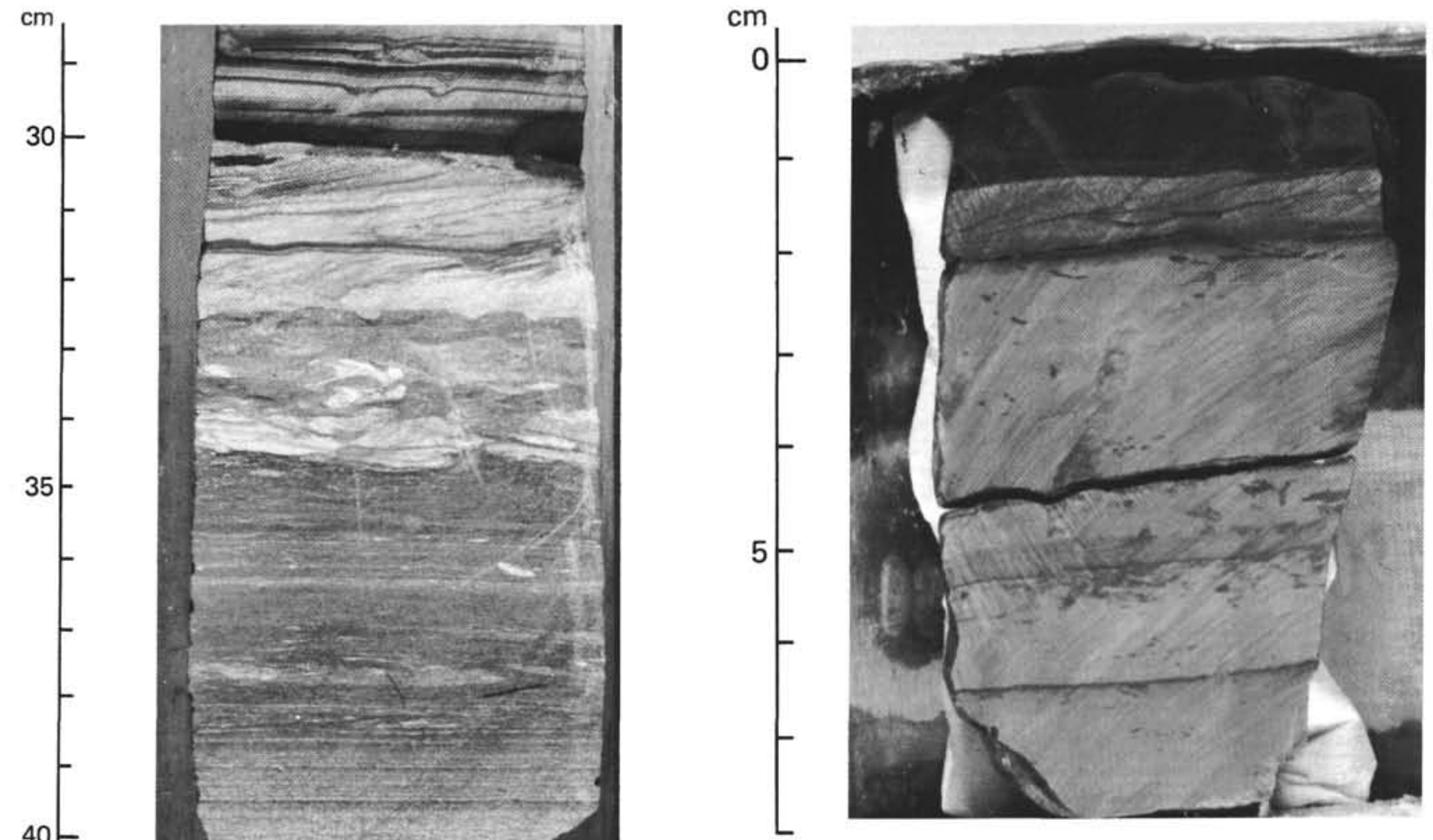

Figure 30. 416A-57-1,CC (deepest sample at Site 416). Thin limestone turbidites (bases at 6.5 and $5 \mathrm{~cm}$ ) and quartz-sandstone turbidite (base at $2 \mathrm{~cm}$ ). Small burrows, especially in upper parts of limestone units.

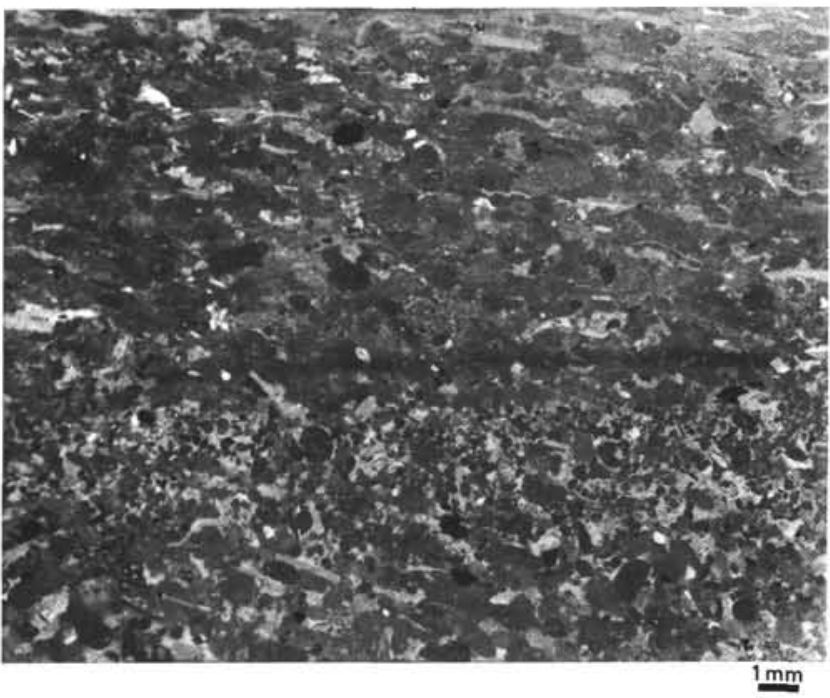

Figure 31. 416A-37-3, 29-31 cm. Photomicrograph (plane-polarized light) of coarse calcarenite near the base of a calcareous-turbidite layer. The abundant dark-colored lumps are micritic limestone and benthic foraminifers.

Figure 29. 416A-37-2, 30-50 cm. Calcareous-turbidite layer, beginning at $44 \mathrm{~cm}$. The base is coarse calcarenite with micritized benthic foraminifers; mollusk, echinoid, and bryozoan fragments; ooids; lumps of calpionellid limestone (dark colored); glauconite; and phosphatic fish debris. The top of the bed is at $34.5 \mathrm{~cm}$.

Cores 51 and 52 , where it is characteristically associated with abundant carbonaceous plant matter.

The calcarenites are also cemented by blocky ferroan calcite, and relics of an even, drusy cement can be found occasionally. The micritic limestones are thoroughly re- 


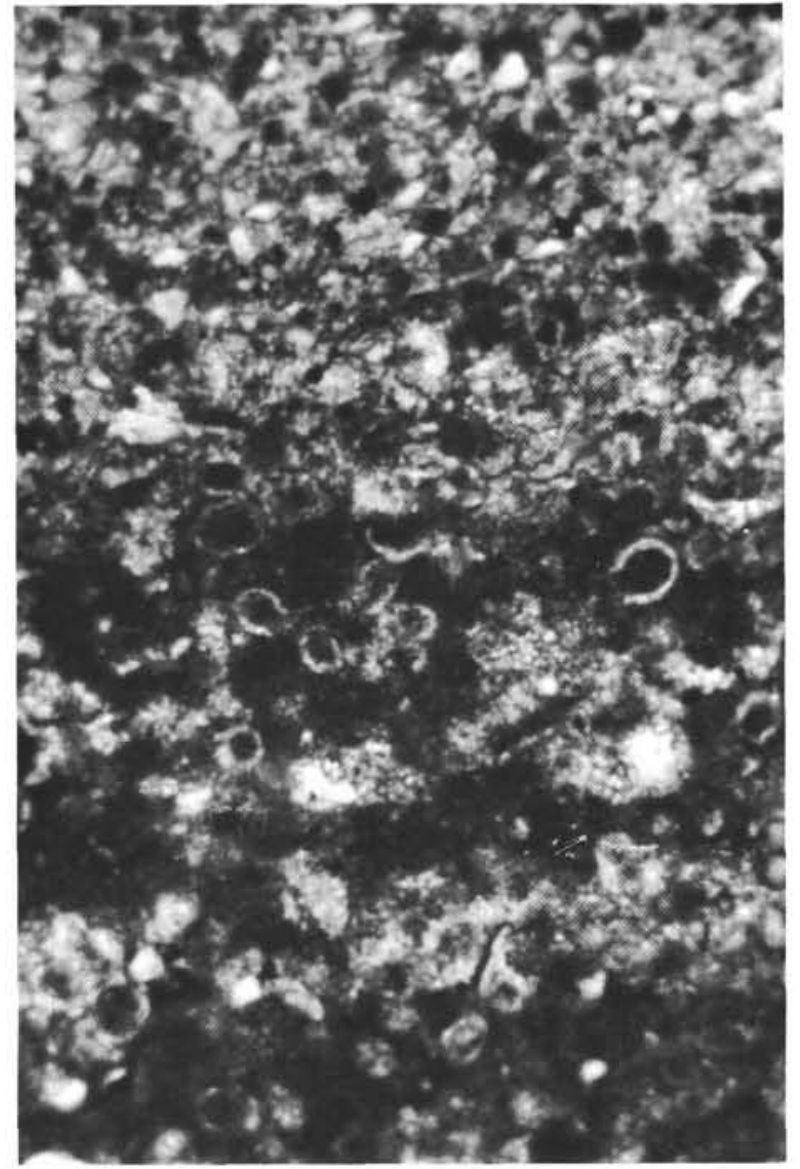

Figure 32. 416A-41-1. Photomicrograph (plane-polarized light) of a calcarenite, showing calpionellids in micrite grains.

crystallized and contain only a few per cent of recognizable nannofossils. The rest is slightly ferroan, neomorphic calcite. The very low porosity and high degree of lithification of these rocks may be due to a high content of unstable carbonate material (thus, a high diagenetic potential) of the original sediment. Pressure solution by overburden is in its incipient stage, as indicated by occasional horsetail structures and microstylolites along bedding planes. More conspicuous are well-developed vertical stylolites. When taken apart along the clay seam, they do not show the cones otherwise characteristic of stylolites, but have a distinctly linear pattern like slickensides, suggesting that they were formed by translational movement rather than horizontal compaction.

\section{Trends in Units VI and VII}

At Site 416, beginning at Core 416A-9, a continuous record was kept of the thickness of turbidite beds, and the proportion of each of the various Bouma intervals in the beds. This record was extended upward to Core 32 at Site 370 by inspection of the visual descriptions and core photographs. We thus have a nearly continuous record for the interval extending from about 835 to 1624 meters below the sea floor. Several features of this record are notable.

The total number of beds counted in units VI and VII was 4597 in 316.64 meters of recovered core, giving a

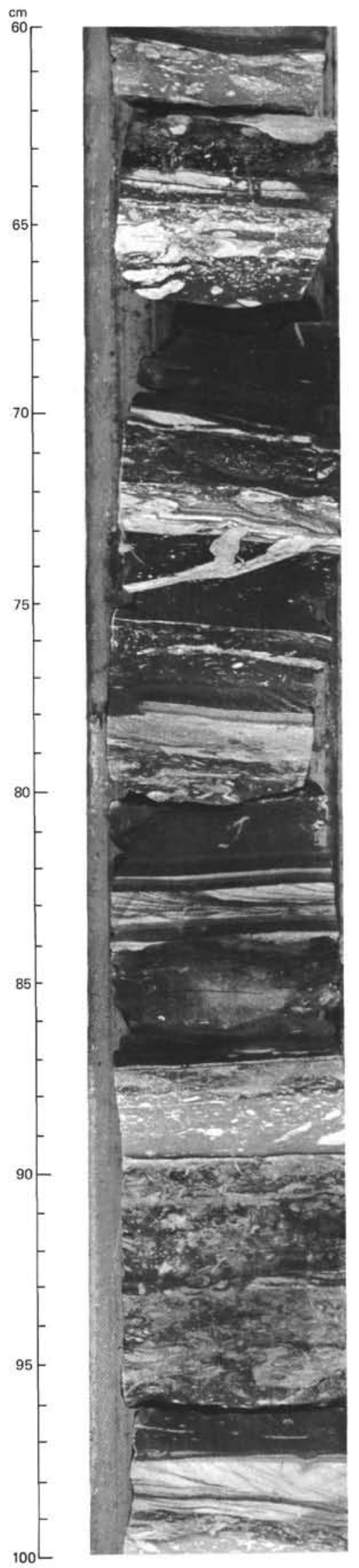

Figure 33. 416A-38-1, 60-100 cm. Burrowed, cyclic tur bidite units, showing various intensities of burrowing. Mainly Chondrites and Helminthoida. 


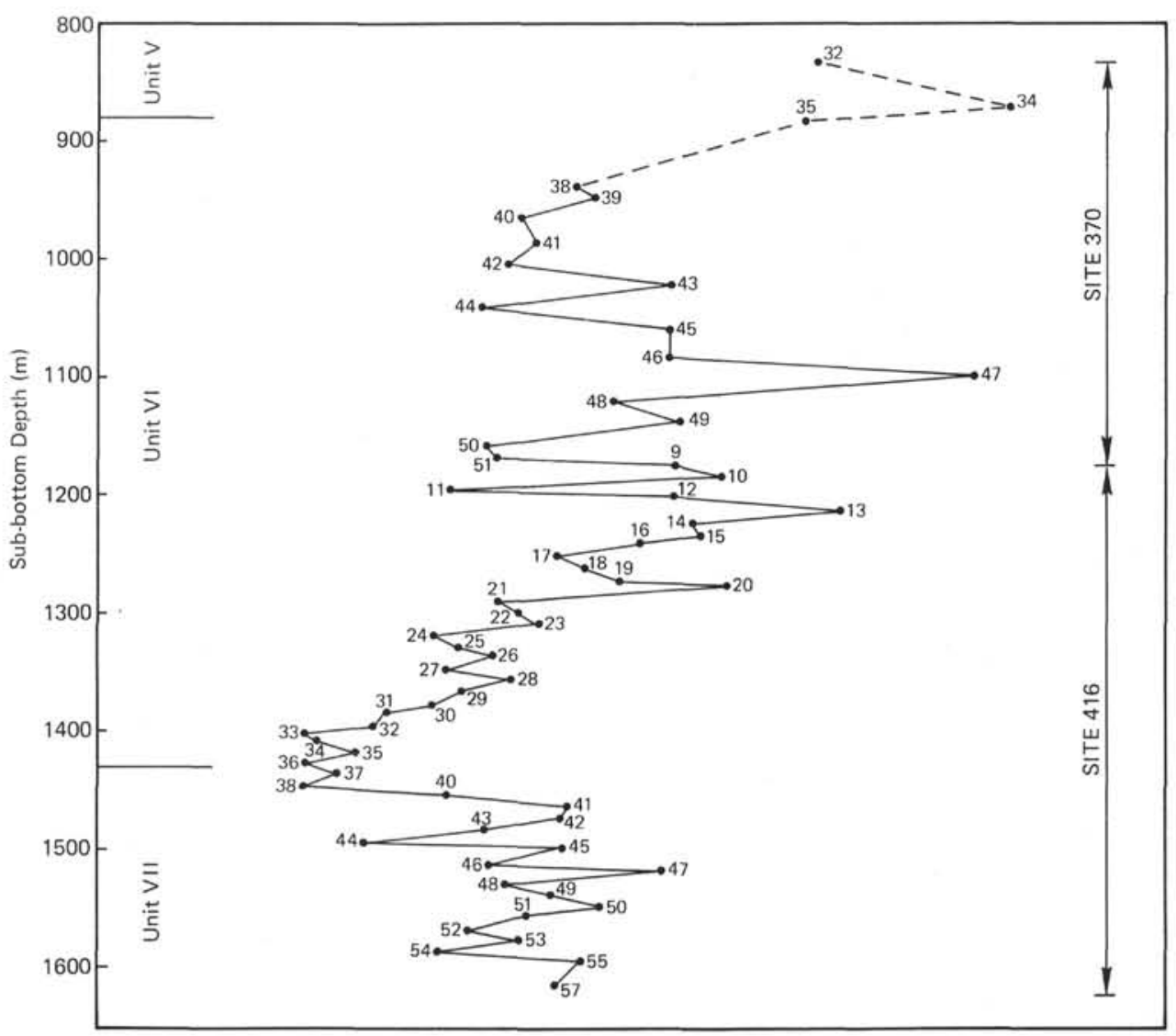

Figure 34. Mean thickness of cycles in units VI and VII, combining data from Sites 416 and 370 . The mean thickness for each core is plotted at the depth of the top of the core.

mean thickness of $6.9 \mathrm{~cm}$. If we assume that the recovery was unbiased, that is, that beds of all thicknesses were recovered in the proportions they occupy in the total 744-meter thickness of units VI and VII, we can extrapolate the 4597 beds to about 10,000 . If we take the age of Core $416 \mathrm{~A}-57$ as 137 m.y., and the age of Core 370-35 as $121 \mathrm{~m} . \mathrm{y}$., the mean time between turbidity currents reaching this site was about 1600 years.

The mean bed thickness for each core is shown in Figure 34, where thickness is plotted at the depth of the top of the core below the sea floor. The main features of this graph are the trend toward decreased bed thicknesses in the lower half of unit VI and the abrupt increase in bed thickness near the top of unit VII.

The thick beds in the upper part of unit VI are quartz-rich, and the thinner beds in the lower part of that unit commonly include reddish zeolitic mud as the topmost member of the cycle. The increase in bed thickness in unit VII is partly accounted for by the abundance of calcareous cycles, which tend to form a thickness population distinct from the more-quartzose cycles in unit VII. The two populations are shown on Figure 35 , where the mean thickness for the calcareous cycles in Cores $416 \mathrm{~A}-45$ through 57 is $9.6 \mathrm{~cm}$, while the mean thickness in the quartzose cycles is $4.7 \mathrm{~cm}$. The ratio of calcareous to quartzose beds in this interval is about 1:5.

The near straightness of the curves on Figure 35 indicates that the thicknesses closely follow a log-normal distribution, and further suggests that the coring pro- cess does not strongly bias the thickness data by systematically eliminating either thick or thin beds. Plots for individual cores show more deviation from a straight line. On the other hand, when mean bed thickness for each core is plotted against core recovery (Figure 36) some trends can be seen: in the thick-bedded quartzose sections from Cores $416 \mathrm{~A}-9$ to 31 , where recovery is poor, mainly thick beds are recovered; in the thinnerbedded sequence from Cores $416 \mathrm{~A}-32$ to 38 , the opposite is true. In unit VII, no trend is evident.

In parallel with the overall decrease in mean bed thickness in the lower half of unit VI, there is a tendency toward cycles beginning with higher Bouma divisions (Figure 37).

A search was made for shorter trends that might be superimposed on the large-scale thickness and Boumadivision trends seen in Figures 34 and $37-$ for example, fining- or coarsening-upward sequences - but very little evidence, if any, was found. Figure 38 shows a smoothed bed-thickness plot. The 10-bed moving average should remove the worst of the noise, but will also suppress very short trends. The most reliable part of the plot is from Cores 416A-32 through 37, where core recovery was mainly excellent and, thus, lack of continuity between cores is not a serious problem. The plot shows strong oscillations, but no clear trends. Lower, in Cores $416 \mathrm{~A}-41$ to 43 , there may be a thickening-upward trend, and higher, in Cores 370-47 through 51 (not shown), there may be a similar trend, but here the recov- 


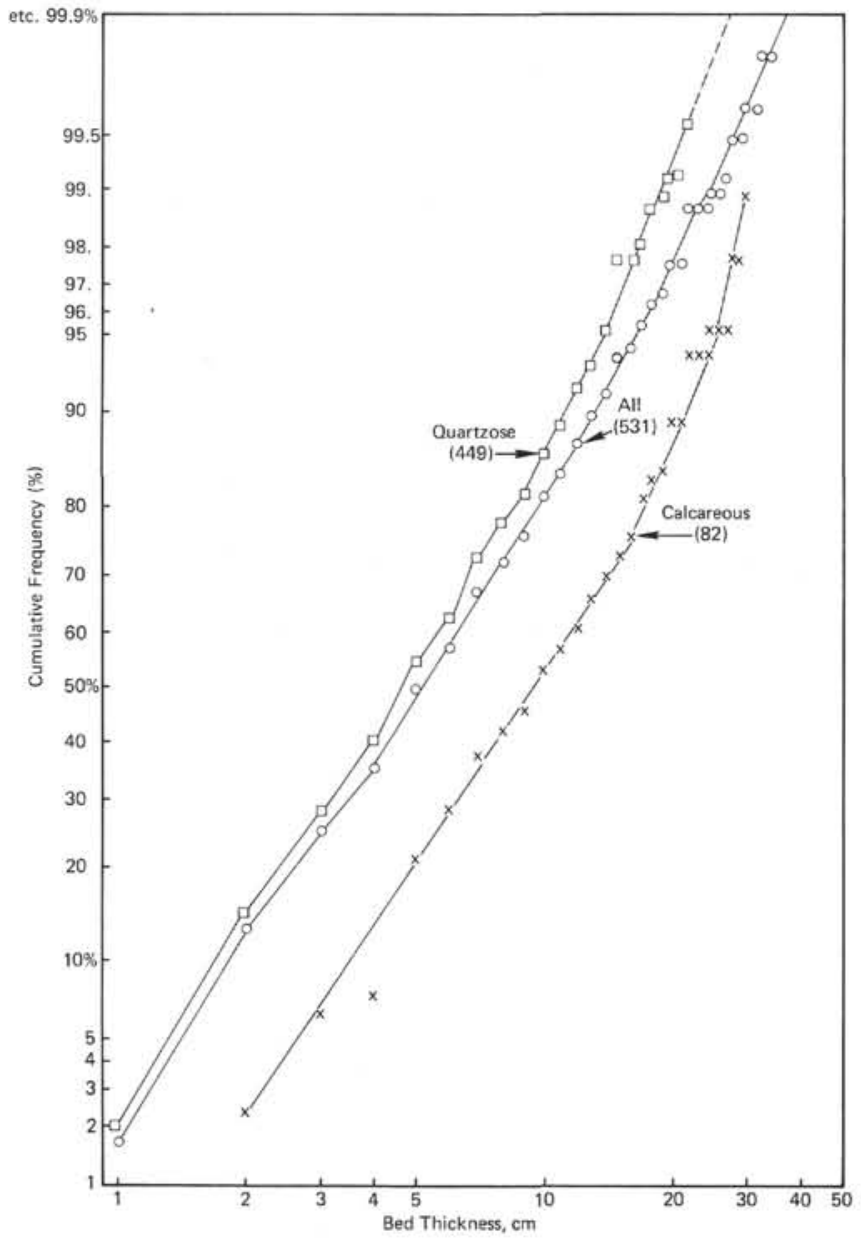

Figure 35. Cumulative-frequency curves for $\log$ bed thickness for Cores 416A-45 through 57 represented on a probability scale. There are 449 quartzose and 82 calcareous beds. Mean thickness for the quartzose beds is about $4.7 \mathrm{~cm}$, and for the calcareous beds about $9.6 \mathrm{~cm}$.

ery rate was very low $(\sim 30 \%)$. The impression from Figure 38 is that only the major, very long-term trends are real, and that the rest is random fluctuation. The standard deviation at any point is from half to two thirds of the value, which suggests a large element of randomness in thickness variations.

In addition to these trends, there are specific aspects of the sequence which reflect the overall changes. Calcareous material first appears as a distinct lithology in Core 416A-10, which contains centimeter-scale beds of greenish-gray, white-flecked siltstone with sharp upper and lower contacts. Such beds seem to be the last vestiges of the calcareous clastic materials of lower cores. The last trace of the upper unit of the calcareous sequence is in Core 416A-11, where discrete beds of homogeneous, dusky yellow-green (5GY 5/2) nannofossil marlstone were first recorded. The appearance of two types of cycles, quartzose and calcareous, begins between Cores 416A-11 and 416A-14 and is definite by Core 416A-20. Calcarenites appear in Core 416A-26. Quartzose cycles predominate until about Core 416A28 , where the two types occupy approximately equal

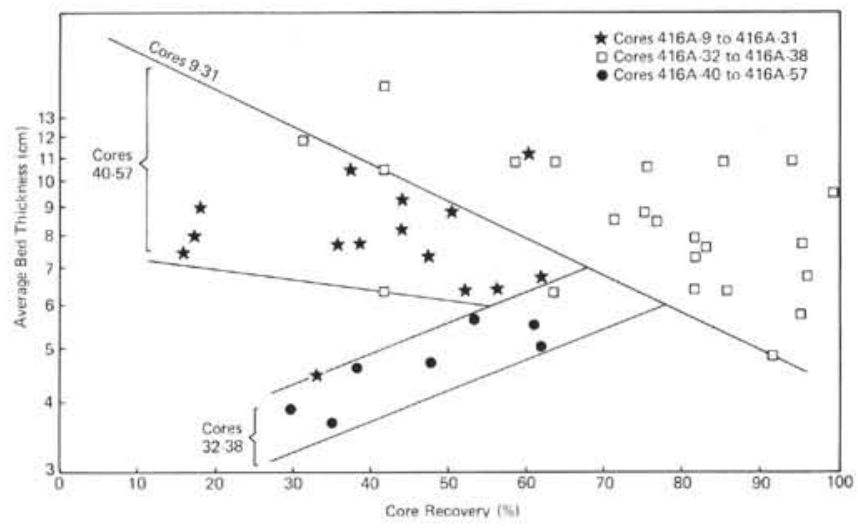

Figure 36. Mean bed thickness versus core recovery for cores from units VI and VII at Site 416.

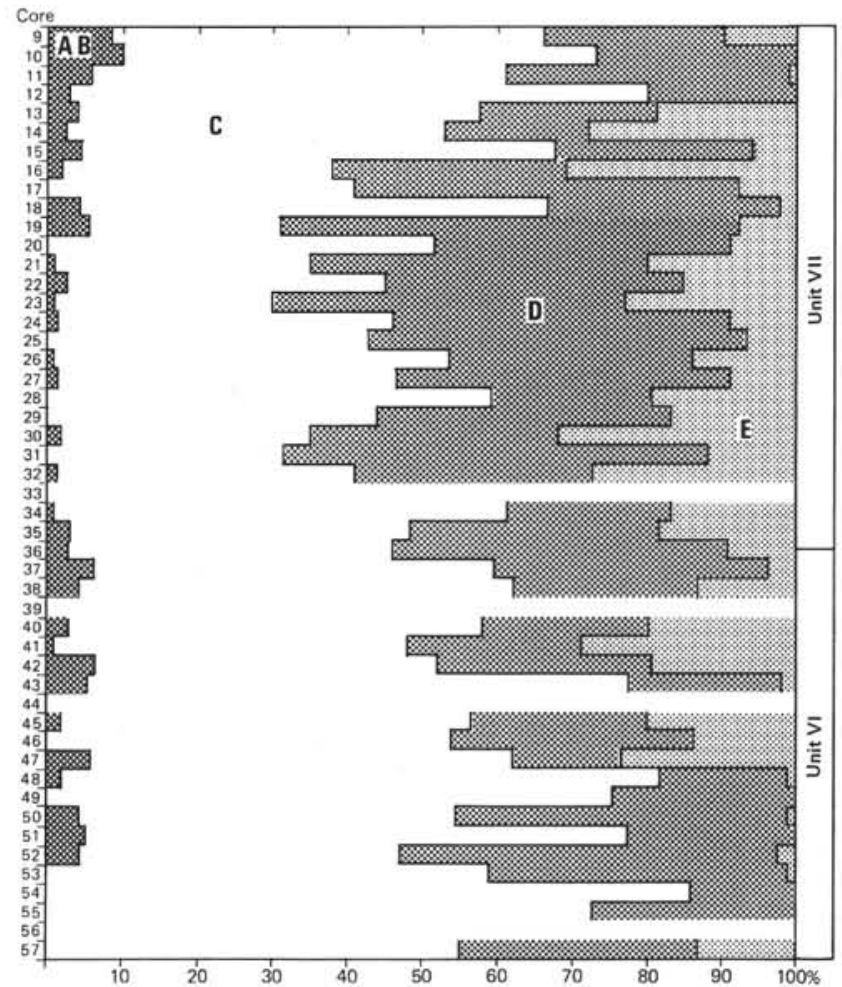

Figure 37. Diagram showing the percentages of the turbidite cycles in the core that begin with Bouma divisions $A, B, C, D$, or $E$, for each core in units VI and VII at Site 416.

volumes. In the lower part of unit $\mathrm{V}$, the green cycles tend to be thicker, with more obvious erosional bases. Estimates of ratios between brown and green cycles are probably biased, because the brown mudstone shows a greater tendency than the green marlstone to wash out (indicated by undergauge core).

A significant variable that may considerably influence the acoustic properties of the formation is the amount of well-lithified sediment (Figure 39). The curve shows a sharp peak at Core 37, very close to the first appearance of the limestones, immediately followed by a minimum at Core 38. From there, the limestone portion of the cores fluctuates considerably, but seems to in- 


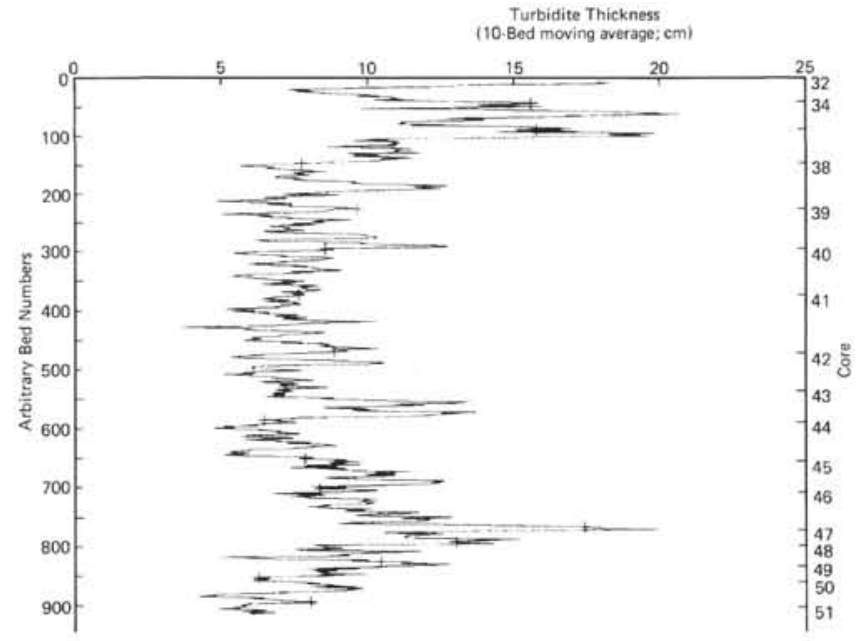

Figure 38. Ten-bed moving average of turbidite bed thickness in units VI and VII at Sites 416 and 370. The core numbers are given at the right and the (arbitrary) bed numbers at the left. No account was made of missing intervals between or within cores in calculating the moving average. Standard deviation of any point on the curve is from half to two thirds of the value.

crease gradually down to Core 50 , then to decrease below that level.

Burrowing is noticeable throughout unit VI, especially near the tops of cycles. The incidence of burrows in- creases, however, from Core 416A-29 downwards, and Zoophycos is found for the first time.

In unit VII, Cores 37 to 40 , burrows are prominent (Figure 33), and the fauna is diverse. It includes Chondrites, Helminthoida, and Zoophycos. This assemblage disappears rather rapidly, and burrows below Core 41 are scarce and less varied (Chondrites and Helminthoida only). Core 53 has scarcely any burrows.

\section{GEOCHEMISTRY}

\section{Organic Geochemistry}

The Cenozoic section at Site 416 (Hole 416A) does not show anything unusual in regard to either content or composition of the gas. From the top of the section down to 300 meters, the gas content is very low, so that even methane is not routinely detectable; that is, its concentration is less than 0.0005 per cent. Then, at a depth of about 450 meters (beginning at Core 416A-3), the $\mathrm{CH}_{4}$ content became noticeably higher (more than $10 \%$ ) simultaneously with the first appearance of ethane (Table 5).

Pyrolysis data testifies to the abundance of terrestrial humic material (Table 6). The predominance of this type of organic matter in a deep basin may be related to the terrigenous turbidites observed in most of the Cenozoic cores.

The results of the carbonate, organic-carbon, and $\mathrm{C} / \mathrm{N}$ analyses for Site 416 show that most of the sediments of Hole 416A have similar $\mathrm{CaCO}_{3}$ contents, with an average of 23 per cent, except for $416 \mathrm{~A}-1-1$ and

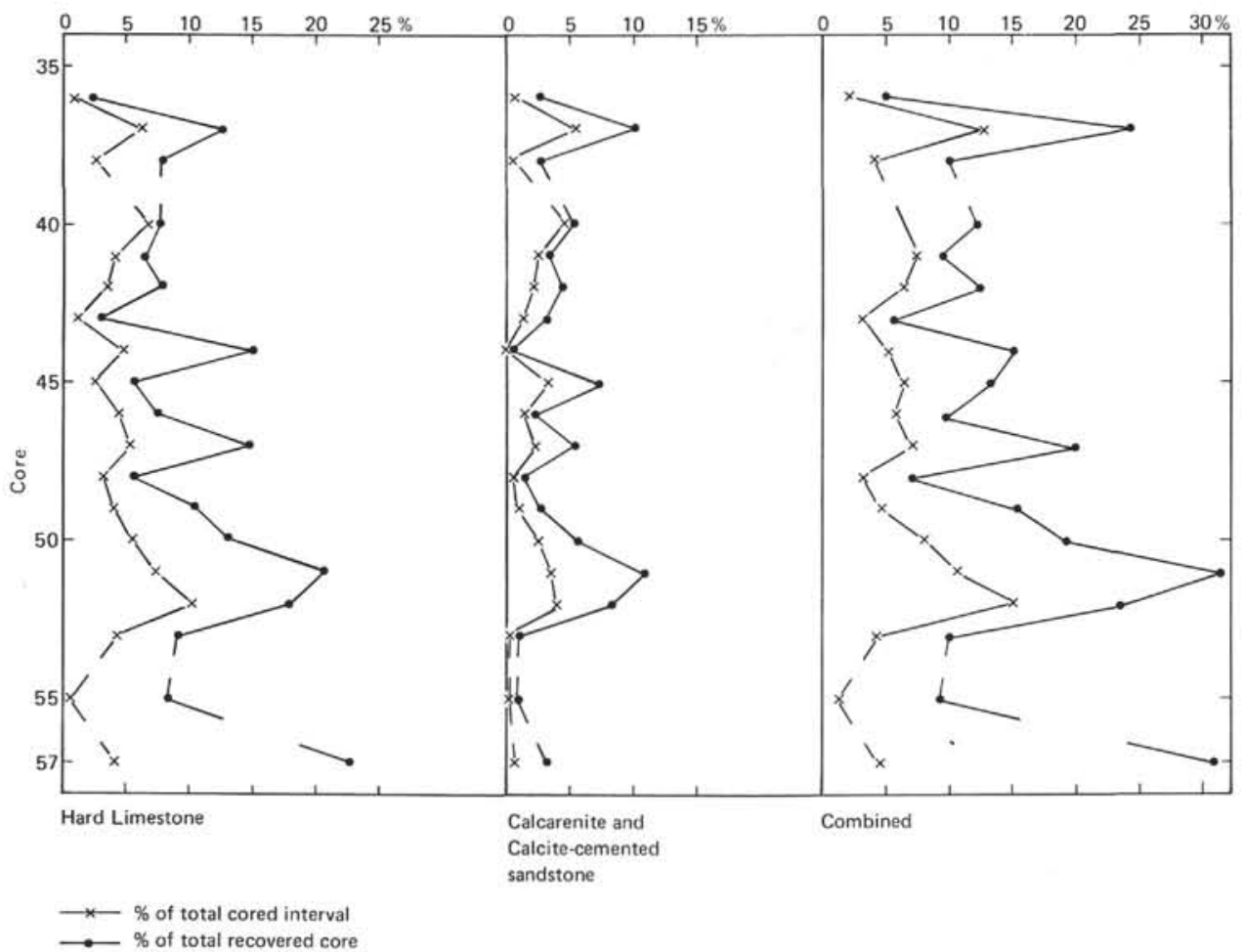

Figure 39. Content of hard layers in unit VII. The percentage of the thickness in a core occupied by hard micritic limestone, calcarenite, or calcite-cemented sandstone is plotted for each core. 
TABLE 5

Concentrations of $\mathrm{CH}_{4}, \mathrm{CO}_{2}$, and $\mathrm{C}_{2}-\mathrm{C}_{5}$, Site 416

\begin{tabular}{|c|c|c|c|c|c|c|c|c|c|}
\hline \multirow[b]{2}{*}{ Core } & \multirow{2}{*}{$\begin{array}{l}\text { Sub-bottom } \\
\text { Depth } \\
\text { (m) }\end{array}$} & $\mathrm{CH}_{4}$ & $\mathrm{CO}_{2}$ & $\mathrm{C}_{2} \mathrm{H}_{6}$ & $\mathrm{C}_{3} \mathrm{H}_{8}$ & $i-\mathrm{C}_{4} \mathrm{H}_{10}$ & $n-\mathrm{C}_{4} \mathrm{H}_{10}$ & $i-\mathrm{C}_{5} \mathrm{H}_{12}$ & $n-\mathrm{C}_{5} \mathrm{H}_{12}$ \\
\hline & & \multicolumn{2}{|c|}{ (vol. \%) } & \multicolumn{6}{|c|}{ (ppm by vol.) } \\
\hline $416 \mathrm{~A}-1$ & $146-155.5$ & & 0.13 & & & & & & \\
\hline 2 & $293-307.5$ & & 0.13 & & & & & & \\
\hline 3 & $450-459.5$ & 11.4 & 0.36 & 18 & & & & & \\
\hline 5 & $754-763.5$ & 10.7 & 0.09 & 35 & 0.5 & & & & \\
\hline 6 & $887-896.5$ & 22.0 & 0.11 & 46.7 & 0.5 & & & & \\
\hline 7 & $991.5-1093$ & 0.5 & 0.09 & 2.4 & 0.52 & \multirow{2}{*}{\multicolumn{2}{|c|}{$(i+n)=0.5$}} & \multicolumn{2}{|c|}{$(i+n)=0.4$} \\
\hline 9 & $1176.9-1189.4$ & 0.98 & 0.10 & 4 & & & & & \\
\hline 11 & $1194.8-1204.3$ & 0.06 & 0.09 & 5 & & \multirow{3}{*}{0.6} & \multirow{3}{*}{0.4} & \multirow{3}{*}{0.2} & \multirow{3}{*}{0.16} \\
\hline 12 & $1204.3-1213.8$ & 0.17 & 0.05 & 11.1 & 1.5 & & & & \\
\hline 13 & $1213.8-1222.4$ & 0.08 & 0.05 & 3.8 & 0.2 & & & & \\
\hline 14 & $1223.4-1232.9$ & 0.08 & 0.04 & 5.0 & 0.3 & & & & \\
\hline 15 & $1232.9-1242.5$ & 0.1 & 0.08 & 3.2 & 0.07 & & & & \\
\hline 16 & $1242.5-1252.0$ & 0.19 & 0.06 & 5.3 & 0.15 & & & & \\
\hline 17 & $1252.0-1261.5$ & 0.09 & 0.06 & 5.0 & 0.6 & & & & \\
\hline 18 & $1261.5-1271$ & 0.09 & 0.08 & 2.4 & 0.3 & & & & \\
\hline 19 & $1271-1277.5$ & 0.09 & 0.06 & 3.2 & 0.6 & & & \multirow{2}{*}{\multicolumn{2}{|c|}{$(i+n)=0.12$}} \\
\hline 20 & $1277.5-1287$ & 0.15 & 0.08 & 4.5 & 0.7 & 0.21 & 0.17 & & \\
\hline 21 & $1290-1299.5$ & 0.07 & 0.05 & 5.2 & 1.8 & 0.45 & 0.31 & 0.3 & \\
\hline 22 & $1299.5-1309.1$ & 0.23 & 0.13 & 9.2 & 3.3 & 0.97 & 0.93 & 0.78 & 0.32 \\
\hline 23 & $1309.1-1318.6$ & 0.15 & 0.08 & 6.1 & 2.1 & 0.64 & 0.56 & 0.55 & 0.33 \\
\hline 24 & $1318.6-1327.7$ & 0.11 & 0.08 & 5.4 & 1.9 & 0.56 & 0.54 & 0.42 & 0.32 \\
\hline 25 & $1327.7-1336.7$ & 0.08 & 0.07 & 3.3 & 1.4 & 0.35 & 0.7 & 0.4 & 0.3 \\
\hline 26 & $1337.2-1346.7$ & 0.09 & 0.08 & 3.0 & 1.0 & 0.35 & 0.5 & 0.43 & 0.42 \\
\hline 28 & $1356.4-1365.9$ & 0.04 & 0.07 & 1.3 & 0.45 & 0.22 & 0.22 & \multicolumn{2}{|c|}{$(i+n)=0.52$} \\
\hline 29 & $1365.7-1375.2$ & 0.04 & 0.05 & 3.3 & 1.8 & 0.45 & 0.45 & \multicolumn{2}{|c|}{$(i+n)=0.8$} \\
\hline 30 & $1375.2-1384.6$ & 0.04 & 0.05 & 2.6 & 1.0 & 0.43 & 0.69 & \multirow{2}{*}{\multicolumn{2}{|c|}{$(i+n)=1.11$}} \\
\hline 31 & $1384.6-1394.1$ & 0.02 & 0.04 & 0.3 & 0.35 & & & & \\
\hline 32 & $1394.1-1403.6$ & 0.03 & 0.04 & 1.9 & 1.0 & 0.1 & 0.32 & \multicolumn{2}{|c|}{$(i+n)=0.4$} \\
\hline 34 & $1406.8-1416.4$ & 0.12 & 0.04 & 4.8 & 2.4 & 0.7 & 0.85 & \multicolumn{2}{|c|}{$(i+n)=1.3$} \\
\hline 36 & $1425.4-1435.0$ & 0.018 & 0.04 & 0.7 & 0.4 & & & & \\
\hline 40 & $1454.5-1463.9$ & 0.02 & 0.04 & 0.9 & 0.4 & 0.04 & 0.2 & \multicolumn{2}{|c|}{$(i+n)=0.47$} \\
\hline 45 & $1501.2-1510.6$ & 0.001 & 0.01 & 0.99 & 0.78 & 0.05 & 0.24 & \multirow{2}{*}{\multicolumn{2}{|c|}{$\begin{array}{l}(i+n)=0.29 \\
(i+n)=0.2\end{array}$}} \\
\hline 49 & $1539.1-1548.6$ & 0.033 & 0.06 & 0.5 & 0.26 & $(i+n$ & $=0.34$ & & \\
\hline 50 & $1548.6-1558.0$ & 0.036 & 0.07 & 0.73 & 0.38 & 0.14 & 0.29 & \multicolumn{2}{|c|}{$(i+n)=0.3$} \\
\hline 51 & $1558.0-1567.4$ & 0.052 & 0.05 & 1.0 & 0.32 & 0.22 & 0.17 & \multicolumn{2}{|c|}{$(i+n)=0.38$} \\
\hline 52 & $1567.4-1576.8$ & 0.052 & 0.05 & 0.95 & 0.59 & 0.16 & 0.13 & \multirow{2}{*}{\multicolumn{2}{|c|}{$\begin{array}{l}(i+n)=0.34 \\
(i+n)=0.3\end{array}$}} \\
\hline 53 & $1576.8-1586.2$ & 0.02 & 0.08 & 0.56 & 0.37 & 0.1 & 0.17 & & \\
\hline
\end{tabular}

416A-5, CC. Core 416A-1-1, which consists of nannofossil and marly ooze of the early Pliocene, shows the highest value $(70.5 \%)$. 416A-5, CC, which is possibly as old as Cretaceous, contains only 1.5 per cent $\mathrm{CaCO}_{3}$.

Organic-carbon content in the Cenozoic ranges from 0.4 to 1.8 per cent, with an average of 1.2 per cent, approximately two and a half times as much as the average in the Cenozoic at Site 415.

The major part of the Cretaceous section recovered at this site consists of turbidite sequences of Hauterivian and Valanginian age. The concentration of organic matter throughout the section appears relatively high and averages about 0.8 to 1.0 per cent. Apart from disseminated organic matter, several layers (1-5 mm thick) of black, carbonaceous material were observed. Some of these layers contain grains of amber, which were clearly distinguishable by their characteristic yellow and brownish translucence under the microscope, and by their fluorescence under ultraviolet light. This finding, apart from general geological interest, unambiguously indicates a terrestrial origin for at least part of the organic matter.

It is of interest to follow the pattern of the change in gaseous-hydrocarbon composition and organic-matter maturity with depth throughout this thick and rather homogeneous turbidite succession, for it is within this facies that we reach the depths at which liquid hydrocarbons first begin to be generated. At the top of the Cretaceous, the gas samples (Core 416A-6) contained as much as 22 per cent methane by volume, but then the concentration of methane declined quickly with depth, and remained within the range 0.01 to 0.2 per cent throughout the Hauterivian-Valanginian turbidite succession (Table 5). These low concentrations made gas-chromatograph analysis difficult. In fact, only the samples taken from cores that had been standing 2 to 4 hours on the rack could be analyzed with appropriate accuracy.

In spite of the low concentration, there are some clear trends in the composition of the gas. The percentage of ethane decreases steadily with depth, and becomes less 
TABLE 6

Carbon and Nitrogen Contents and Pyrolysis Data, Site 416

\begin{tabular}{|c|c|c|c|c|c|c|c|}
\hline $\begin{array}{c}\text { Sample } \\
\text { (interval in } \mathrm{cm} \text { ) }\end{array}$ & $\begin{array}{c}\text { Depth } \\
\text { Below } \\
\text { Sea } \\
\text { Floor } \\
(\mathrm{m})\end{array}$ & $\mathrm{C}_{\text {org }}$ & $\mathrm{CO}_{3}$ & $\mathrm{~N}_{2}$ & $\mathrm{~s}_{1}+\mathrm{s}_{2}$ & $\begin{array}{c}\text { olysis Dat: } \\
\mathrm{s}_{1} \\
\mathrm{~s}_{1}+\mathrm{s}_{2}\end{array}$ & $\begin{array}{l}T_{\mathrm{M}} \\
\left.{ }^{\circ} \mathrm{C}\right)\end{array}$ \\
\hline $\begin{array}{r}16-1-1,54-55 \\
1-2,27-28 \\
2-1,41-42 \\
2-2,48-50 \\
2-4,50-51\end{array}$ & $\begin{array}{l}146.5 \\
147.8 \\
298.4 \\
300.0 \\
303.0\end{array}$ & $\begin{array}{l}0.95 \\
1.25 \\
- \\
1.21 \\
0.42\end{array}$ & $\begin{array}{l}70.5 \\
19.0 \\
- \\
22.0 \\
26.5\end{array}$ & $\begin{array}{l}0.08 \\
0.11 \\
- \\
0.11 \\
0.04\end{array}$ & $\begin{array}{l}- \\
0.10 \\
0.77 \\
0.61 \\
0.36\end{array}$ & $\begin{array}{l}- \\
0.0 \\
0.0 \\
1.5 \\
0.0\end{array}$ & $\begin{array}{l}- \\
417 \\
419 \\
417 \\
407\end{array}$ \\
\hline $\begin{array}{l}3-1,68-70 \\
3-3,66-68 \\
5, C C, 26-27 \\
6-2,17-18 \\
6-3,127\end{array}$ & $\begin{array}{l}450.7 \\
453.7 \\
755.3 \\
892.7 \\
895.3\end{array}$ & $\begin{array}{l}1.22 \\
1.45 \\
1.80 \\
2.45 \\
-\end{array}$ & $\begin{array}{r}26.5 \\
23.5 \\
1.5 \\
1.5 \\
-\end{array}$ & $\begin{array}{l}0.10 \\
0.14 \\
0.14 \\
0.17 \\
0.13\end{array}$ & $\begin{array}{l}0.90 \\
1.83 \\
3.61 \\
3.92 \\
7.31\end{array}$ & $\begin{array}{l}1.7 \\
1.5 \\
0.1 \\
0.4 \\
0.2\end{array}$ & $\begin{array}{l}412 \\
421 \\
429 \\
423 \\
427\end{array}$ \\
\hline $\begin{array}{l}7-1,15-20 \\
7-1,34-36 \\
7-3,91-93 \\
9-1,64-66 \\
9-1,73-77\end{array}$ & $\begin{array}{r}991.7 \\
991.8 \\
995.4 \\
1177.5 \\
1177.6\end{array}$ & $\begin{array}{l}0.83 \\
0.38 \\
0.58 \\
0.65 \\
0.28\end{array}$ & $\begin{array}{r}8.5 \\
27.7 \\
24.0 \\
7.5 \\
21.0\end{array}$ & $\begin{array}{l}0.10 \\
0.02 \\
0.05 \\
0.05 \\
0.02\end{array}$ & $\begin{array}{l}0.40 \\
0.06 \\
0.11 \\
0.43 \\
0.10\end{array}$ & $\begin{array}{r}11.6 \\
-\overline{18.0} \\
2.8 \\
9.0\end{array}$ & $\begin{array}{l}422 \\
- \\
422 \\
423 \\
425\end{array}$ \\
\hline $\begin{array}{l}9-1,94-95 \\
9-5,68-70 \\
10-2,140-143 \\
11-3,90-94 \\
11-5,117-120\end{array}$ & $\begin{array}{l}1177.9 \\
1183.6 \\
1188.3 \\
1198.9 \\
1202.0\end{array}$ & & $\begin{array}{r}30.5 \\
20.5 \\
7.5 \\
9.5 \\
7.5\end{array}$ & $\begin{array}{l}0.02 \\
0.07 \\
0.08 \\
0.08 \\
0.06\end{array}$ & $\begin{array}{l}0.90 \\
0.70 \\
0.47 \\
0.36 \\
0.50\end{array}$ & & $\begin{array}{l}426 \\
427 \\
426 \\
423 \\
426\end{array}$ \\
\hline $\begin{array}{l}12-1,72-74 \\
13-2,110-112 \\
14-5,25-27 \\
15-4,100-103 \\
16-1,80-82\end{array}$ & $\begin{array}{l}1205.0 \\
1216.4 \\
1228.7 \\
1237.4 \\
1243.3\end{array}$ & & $\begin{array}{r}22.5 \\
4.5 \\
2.5 \\
13.0 \\
29.0\end{array}$ & & $\begin{array}{l}0.66 \\
0.53 \\
0.51 \\
0.42 \\
0.45\end{array}$ & $\begin{array}{l}1.0 \\
2.0 \\
1.6 \\
4.1 \\
2.0\end{array}$ & $\begin{array}{l}424 \\
429 \\
425 \\
426 \\
424\end{array}$ \\
\hline $\begin{array}{l}16-2,83-84 \\
16-3,13-15 \\
17-3,83-85 \\
18-4,96-98 \\
19, \text { CC, } 0-2\end{array}$ & $\begin{array}{l}1244.8 \\
1245.6 \\
1255.8 \\
1267.0 \\
1277.5\end{array}$ & & $\begin{array}{r}2.0 \\
4.5 \\
5.0 \\
28.0 \\
18.5\end{array}$ & & & & $\begin{array}{l}421 \\
425 \\
426 \\
427 \\
424\end{array}$ \\
\hline $\begin{array}{l}20-3,29-30 \\
21-4,82-84 \\
22-4,3-5 \\
22, \mathrm{CC} \\
23-3,20-23\end{array}$ & $\begin{array}{l}1280.8 \\
1295.3 \\
1303.0 \\
1309.1 \\
1312.3\end{array}$ & $\begin{array}{l}0.69 \\
0.66 \\
0.70 \\
- \\
1.40\end{array}$ & $\begin{array}{r}20.7 \\
11.0 \\
23.5 \\
- \\
15.5\end{array}$ & $\begin{array}{l}0.07 \\
0.07 \\
0.04 \\
\overline{0} \\
0.08\end{array}$ & & $\begin{array}{l}3.3 \\
4.6 \\
2.7 \\
9.5 \\
2.7\end{array}$ & $\begin{array}{l}425 \\
425 \\
430 \\
428 \\
426\end{array}$ \\
\hline $\begin{array}{l}24-2,58-59 \\
24-3,34-39 \\
25, \mathrm{CC}, 10-12 \\
26-3,70-72 \\
27-5,79-81\end{array}$ & $\begin{array}{l}1320.7 \\
1321.9 \\
1335.3 \\
1340.9 \\
1353.5\end{array}$ & $\begin{array}{r}36.45 \\
0.69 \\
0.40 \\
0.56 \\
0.59\end{array}$ & $\begin{array}{r}29.5 \\
15.0 \\
8.5 \\
4.5\end{array}$ & & $\begin{array}{r}122.03 \\
0.36 \\
0.17 \\
0.32 \\
0.21\end{array}$ & $\begin{array}{r}0.1 \\
3.8 \\
10.8 \\
7.9 \\
6.1\end{array}$ & $\begin{array}{l}406 \\
426 \\
430 \\
422 \\
424\end{array}$ \\
\hline $\begin{array}{l}28-6,123-125 \\
29-3,12-14 \\
30-1,118-120 \\
31-6,57-62 \\
32-4,43-46\end{array}$ & $\begin{array}{l}1364.9 \\
1368.8 \\
1376.4 \\
1392.7 \\
1399.0\end{array}$ & $\begin{array}{l}0.56 \\
0.44 \\
0.43 \\
0.94 \\
-\end{array}$ & $\begin{array}{r}7.5 \\
3.5 \\
50.5 \\
2.0 \\
-\end{array}$ & $\begin{array}{l}0.05 \\
0.04 \\
0.03 \\
0.07 \\
-\end{array}$ & & $\begin{array}{r}3.7 \\
3.6 \\
3.6 \\
4.0 \\
11.0\end{array}$ & \\
\hline $\begin{array}{l}34-2,97-98 \\
34-2,100-102 \\
35-2,113-115 \\
35-2,119-121 \\
38-1,140-142\end{array}$ & $\begin{array}{l}1409.3 \\
1409.3 \\
1419.0 \\
1419.1 \\
1446.4\end{array}$ & $\begin{array}{l}0.23 \\
0.77 \\
0.50 \\
0.18 \\
0.34\end{array}$ & $\begin{array}{r}3.5 \\
6.0 \\
12.5 \\
18.0 \\
7.0\end{array}$ & & & $\begin{array}{r}6.3 \\
5.0 \\
15.0 \\
7.8 \\
13.0\end{array}$ & $\begin{array}{l}425 \\
428 \\
423 \\
426 \\
426\end{array}$ \\
\hline $\begin{array}{l}38-2,23-25 \\
40-6,99-100 \\
41-4,28-30 \\
42-1,38-40 \\
43-4,78-80\end{array}$ & $\begin{array}{l}1446.7 \\
1463.0 \\
1468.7 \\
1473.7 \\
1487.7\end{array}$ & & $\begin{array}{r}26.5 \\
8.5 \\
28.0 \\
53.0 \\
21.0\end{array}$ & & $\begin{array}{l}0.09 \\
0.07 \\
0.03 \\
0.02\end{array}$ & $\begin{array}{l}- \\
\bar{z} \\
\overline{-}\end{array}$ & $\begin{array}{l}426 \\
424 \\
423 \\
413\end{array}$ \\
\hline $\begin{array}{l}44-2,35-37 \\
47-3,116-118 \\
48-1,80-83 \\
49-1,86-88 \\
49-1,88-90\end{array}$ & $\begin{array}{l}1493.8 \\
1521.1 \\
1530.3 \\
1540.0 \\
1540.0\end{array}$ & $\begin{array}{l}0.47 \\
0.22 \\
0.39 \\
0.37 \\
0.13\end{array}$ & $\begin{array}{r}21.0 \\
9.0 \\
7.5 \\
4.5 \\
25.0\end{array}$ & $\begin{array}{l}0.05 \\
0.03 \\
0.03 \\
0.05 \\
0.02\end{array}$ & $\begin{array}{c}0.13 \\
0.11 \\
-\end{array}$ & $\begin{array}{l}4.8 \\
7.8 \\
7.0 \\
4.8 \\
-\end{array}$ & $\begin{array}{l}426 \\
428 \\
430 \\
430 \\
-\end{array}$ \\
\hline & & & $\begin{array}{r}15.0 \\
16.0 \\
3.0\end{array}$ & & $\begin{array}{c}0.39 \\
\overline{0.10}\end{array}$ & $\begin{array}{c}20.8 \\
\overline{8} .0\end{array}$ & \\
\hline
\end{tabular}

than half the overall concentration of $\mathrm{C}_{2}-\mathrm{C}_{5}$ hydrocarbons below 1400 meters. The most striking fact is the increase in pentane, which becomes one of the major components of the gas at these depths. Thus, from the general pattern of gaseous-hydrocarbon distribution, it appears that we are observing the beginning of generation of liquid hydrocarbon at the depth reached at this site. On the other hand, the other geochemical conditions, including the unfavorable type of organic matter (see pyrolysis data), apparently do not permit appreciable hydrocarbon generation.

The pyrolysis data (Table 6) show that from Core $416 \mathrm{~A}-1$ to $416 \mathrm{~A}-6(0-900 \mathrm{~m})$, the amount of potential hydrocarbons increases from about 0.2 to 1.3 per cent of total organic carbon by weight. Then, between Cores $416 \mathrm{~A}-6$ and $416 \mathrm{~A}-7$, the figure falls to 0.1 per cent. This shift correlates with the transition from hemipelagic mudstone above to terrigenous turbidites below.

From Core 416A-9 to Core 416A-57, the hydrogen index decreases gradually and shows a small negative inflection at about 1430 meters, which correlates with a decrease in bed thickness of turbidites. The gradual decrease of potential hydrocarbon is in good agreement with the decrease of sedimentation rate from Core 9 to Core 57.

The state of maturation can be defined both by the index of production, $S_{1} /\left(S_{1}+S_{2}\right)$, and by the temperature at the top of peak, $S_{2}$. The threshold of maturation at this site is between 1100 and 1200 meters sub-bottom depth. At the deepest sampled level (1615 m), a maximum of production has still not been reached, and the temperature at the top of the $S_{2}$ peak is still at about $432^{\circ} \mathrm{C}$, which, under the conditions observed at Site 416 , puts the deepest samples at the very beginning of the "mature" stage.

Fifty-six samples were taken for calcium-carbonate, organic-carbon, and $\mathrm{C} / \mathrm{N}$ analyses from Cores $416 \mathrm{~A}-7$ to 416A-38. Analytical data are shown in Tables 4, 5, and 6. Calcium-carbonate content ranges from 1.5 per cent to nearly 50 per cent. The variation in $\mathrm{CaCO}_{3}$ seems to originate in the turbidite sequences, in lithologic differences between types of cycles and in lithologic variations within a single graded unit of the turbidites. In general, turbidite cycles with greenish-gray colors have higher concentrations of $\mathrm{CaCO}_{3}$, whereas reddish-brown cycles have lower concentrations. Samples from Core 416A-9, in which three samples were taken from one unit of the turbidite cycle, show a remarkable decrease toward the upper part, from 30.5 to 7.5 per cent $\mathrm{CaCO}_{3}$.

Organic-carbon content ranges from 0.18 to 2.4 per cent, with an average value of 0.8 per cent, except for the coaly carbonaceous materials taken from 416A24-2. The organic-carbon content of the turbidite sediments seems to decrease with increasing depth.

The $\mathrm{C} / \mathrm{N}$ ratio in most of the samples falls within the range 9 to 20, with an average of 14 . A few samples that contain small pieces of coaly material show relatively higher $\mathrm{C} / \mathrm{N}$ ratios ( 29 or 38 exceptionally).

\section{Inorganic Geochemistry}

Only three samples from the Cenozoic and two from the Cretaceous in Hole 416A were analyzed for interstitial-water chemistry (Table 7). In the Cenozoic, all the measured properties show monotonous trends with depth, with the exception of alkalinity. The variations in $\mathrm{Ca}^{++}, \mathrm{Mg}^{++}$, chlorinity, salinity, and $p \mathrm{H}$ compare well with those observed at Site 415. As for Site 415, the pattern of interstitial-water chemistry for the Cenozoic may be attributed to normal diagenetic evolution of chemistry of the pore water. In the Cretaceous, how- 
TABLE 7

Interstitial-Water Data, Site 416

\begin{tabular}{cccccccc}
\hline & $\begin{array}{c}\text { Sub- } \\
\text { bottom } \\
\text { Depth } \\
\text { (m) }\end{array}$ & pH & $\begin{array}{c}\text { Alka- } \\
\text { linity } \\
(\mathrm{meq} / \mathrm{l})\end{array}$ & $\begin{array}{c}\text { Salin- } \\
\text { ity } \\
(\%)\end{array}$ & $\begin{array}{c}\mathrm{Ca}^{++} \\
(\mathrm{mmol} / \mathrm{l})\end{array}$ & $\begin{array}{c}\mathrm{Mg}^{++} \\
(\mathrm{mmol} / \mathrm{l})\end{array}$ & $\begin{array}{c}\mathrm{Cl}^{-} \\
(\%)\end{array}$ \\
\hline $416 \mathrm{~A}-1-1,140-150$ & 147.5 & 7.50 & 2.1 & 37.7 & 16.04 & 46.43 & 21.97 \\
$2-2,140-150$ & 301 & 7.34 & 3.12 & 38.5 & 18.36 & 43.83 & 22.75 \\
$3-2,140-150$ & 453 & 7.25 & 2.52 & 41.0 & 25.88 & 38.99 & 24.74 \\
$6-2,140-150$ & 892 & 7.96 & 1.32 & 55.0 & 48.31 & 58.51 & 32.69 \\
$7-2,140-150$ & 994.5 & 7.77 & 0.56 & 46.2 & 37.87 & 45.33 & 27.47 \\
\hline
\end{tabular}

ever, maximum values for $p \mathrm{H}$, salinity, $\mathrm{Ca}^{++}, \mathrm{Mg}^{++}$, and $\mathrm{Cl}^{-}$at $416 \mathrm{~A}-6-2$, at a depth of about 893 meters, could also be related to an inflow of brines from the large field of evaporites which lies only about $30 \mathrm{~km}$ east of Site 416 (Figure 1). (For further discussion, see Gieskes et al., this volume.)

\section{PHYSICAL PROPERTIES AND WELL-LOGGING MEASUREMENTS}

At Site 416, wet-bulk density, wet-water content, porosity, sound velocity, and acoustic impedance were routinely determined on each core of Hole $416 \mathrm{~A}$ for which such measurements were feasible; the data are listed in Table 8 . Heat conductivity measurements were attempted on soft cores, but because only two were successful these will be presented only in the text. All other physical-property data are displayed on small-scale and large-scale hole plots (Figures 40 and 41). Definitions and the methodology of the laboratory physical properties are presented in Appendix I of this volume, and Schlumberger well-log definitions and methods are discussed in Appendix II of this volume. Unless otherwise stated, all laboratory physical-properties data are at ambient laboratory pressures and temperatures, and all laboratory density, water-content, and porosity data have been corrected for salt (median salinity of $45 \%$ ).

Two thermal conductivities were successfully measured: $416-1-1,55 \mathrm{~cm}$ (nannofossil ooze) had a conductivity of $3.16 \mathrm{mcal} / \mathrm{cm}-\mathrm{s}^{\circ} \mathrm{C}$, and $416-2-2,50 \mathrm{~cm}$ (nannofossil chalk) had a conductivity of $3.06 \mathrm{mcal} / \mathrm{cm}-\mathrm{s}^{\circ} \mathrm{C}$. The analog-GRAPE record indicated a density of 2.01 $\mathrm{g} / \mathrm{cm}^{3}(41.2 \%$ porosity) for both samples.

The Cenozoic section was cored at 150 -meter intervals between 150 and 762 meters sub-bottom; therefore, only the most general trends in physical properties with depth can be seen from the laboratory measurements. Where the cores were disturbed, the only physical property measured was analog-GRAPE wet-bulk density. (See physical-properties core plots preceding core-description sheets at the end of this chapter.)

\section{Interval Sound Velocities}

The geologic section at Site 416 is here divided into seven layers, which are based primarily on physical properties, but also on lithology and well logs. These layers and their approximate interval velocities are as follows:

1. The first layer comprises Pliocene and Pleistocene nannofossil marls and oozes from 0 to 100 meters subbottom, which have an estimated in situ interval velocity of $1.57 \mathrm{~km} / \mathrm{s}$. The boundary at 100 meters and the velocity value of $1.57 \mathrm{~km} / \mathrm{s}$ are completely arbitrary, because the recovered sediments were physically disturbed by the coring operation.

TABLE 8

Physical Properties of Sediments, Site 416

\begin{tabular}{|c|c|c|c|c|c|c|c|c|c|c|c|c|}
\hline \multirow[b]{3}{*}{$\begin{array}{c}\text { Sample } \\
\text { (interval in } \mathrm{cm} \text { ) }\end{array}$} & \multirow{3}{*}{$\begin{array}{l}\text { Sub- } \\
\text { bottom } \\
\text { Depth } \\
\text { (m) }\end{array}$} & \multicolumn{5}{|c|}{ Compressional-Sound Velocity } & \multirow{2}{*}{\multicolumn{2}{|c|}{$\begin{array}{c}\text { GRAPE "Special" } \\
\text { Wet-Bulk Densitya } \\
(2-\text { min count }) \\
\left(\mathrm{g} / \mathrm{cm}^{3}\right)\end{array}$}} & \multirow{3}{*}{$\begin{array}{l}\text { Wet- } \\
\text { Water } \\
\text { Content } \\
\text { (salt } \\
\text { corr.) } \\
(\%)\end{array}$} & \multirow{3}{*}{$\begin{array}{l}\text { Poros- } \\
\text { ityb } \\
(\%)\end{array}$} & \multirow{3}{*}{$\begin{array}{l}\text { Acoustic } \\
\text { Impedance } \\
\mathrm{g} \times 10^{5} \\
\mathrm{~cm}^{2}-\mathrm{s}\end{array}$} & \multirow[b]{3}{*}{ Lithology } \\
\hline & & \multirow{2}{*}{$\begin{array}{c}\| \\
\text { Beds } \\
(\mathrm{km} / \mathrm{s})\end{array}$} & \multirow{2}{*}{ 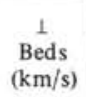 } & \multicolumn{2}{|c|}{ Anisotropy } & \multirow[b]{2}{*}{$\begin{array}{c}\text { Temp. } \\
\left({ }^{\circ} \mathrm{C}\right)\end{array}$} & & & & & & \\
\hline & & & & $\begin{array}{c}\|-1 \\
(\mathrm{~km} / \mathrm{s})\end{array}$ & $\begin{array}{c}(\|-1) / 1 \\
(\%)\end{array}$ & & $\begin{array}{c}\| \\
\text { Beds }\end{array}$ & $\stackrel{\perp}{\text { Beds }}$ & & & & \\
\hline $\begin{array}{c}416 \mathrm{~A}-1-1,32-34 \\
1-1,140-150 \\
1, \mathrm{CC}, 0-2\end{array}$ & $\begin{array}{l}146.32 \\
147.45 \\
147.93\end{array}$ & $\begin{array}{l}1.695 \\
-\overline{7} \\
1.740\end{array}$ & $\begin{array}{l}1.717 \\
1.755\end{array}$ & $\begin{array}{l}-0.022 \\
- \\
-0.015\end{array}$ & $\begin{array}{l}-1.28 \\
-0.85\end{array}$ & $\frac{25}{25}$ & $\overline{-}$ & $\begin{array}{l}1.973 \\
-\overline{1.884}\end{array}$ & $\begin{array}{l}26.84 \\
29.04 \\
27.43\end{array}$ & $\begin{array}{l}51.31 \\
- \\
50.08\end{array}$ & $\begin{array}{l}3.39 \\
- \\
3.31\end{array}$ & $\begin{array}{l}\text { Nannofossil ooze } \\
\text { (Interstitial water) } \\
\text { Nannofossil marl }\end{array}$ \\
\hline $\begin{array}{l}2-1,147-149 \\
2-2,116-118 \\
2-2,140-150 \\
2-4,2-4 \\
2, C C, 8-10\end{array}$ & $\begin{array}{l}299.47 \\
300.66 \\
300.95 \\
302.52 \\
303.35\end{array}$ & $\begin{array}{l}1.860 \\
1.771 \\
- \\
1.659 \\
4.307\end{array}$ & $\begin{array}{l}1.869 \\
1.761 \\
- \\
1.626 \\
-\end{array}$ & $\begin{array}{c}-0.009 \\
0.010 \\
- \\
0.033 \\
-\end{array}$ & $\begin{array}{r}-0.48 \\
0.57 \\
- \\
2.03 \\
-\end{array}$ & $\begin{array}{l}27 \\
27 \\
27 \\
27\end{array}$ & $\begin{array}{r}- \\
- \\
- \\
\overline{2} . \overline{7}\end{array}$ & $\begin{array}{l}1.954 \\
1.744 \\
- \\
1.855 \\
-\end{array}$ & $\begin{array}{r}25.40 \\
34.63 \\
26.29 \\
30.91 \\
9.79\end{array}$ & $\begin{array}{l}48.09 \\
58.52 \\
- \\
55.56 \\
20.60\end{array}$ & $\begin{array}{l}3.65 \\
3.07 \\
- \\
3.02 \\
9.35\end{array}$ & $\begin{array}{l}\text { Foraminifer-nannofossil ooze } \\
\text { Sand } \\
\text { (Interstitial water) } \\
\text { Nannofossil chalk } \\
\text { Porcellanite }\end{array}$ \\
\hline $\begin{array}{l}3-1,113-115 \\
3-2,29-31 \\
3-2,140-150 \\
3-3,99-101\end{array}$ & $\begin{array}{l}451.13 \\
451.79 \\
452.95 \\
453.99\end{array}$ & $\begin{array}{l}1.827 \\
1.766 \\
-\overline{7} \\
1.796\end{array}$ & $\begin{array}{l}1.751 \\
1.694 \\
1 . \overline{771}\end{array}$ & $\begin{array}{l}0.076 \\
0.072 \\
-\quad \\
0.025\end{array}$ & $\begin{array}{l}4.34 \\
4.25 \\
- \\
1.41\end{array}$ & $\begin{array}{l}26 \\
25.5 \\
\overline{25.5}\end{array}$ & $\begin{array}{l}- \\
- \\
-\end{array}$ & $\begin{array}{l}2.030 \\
1.847 \\
- \\
1.982\end{array}$ & $\begin{array}{l}23.65 \\
31.49 \\
27.52 \\
24.42\end{array}$ & $\begin{array}{c}46.52 \\
56.36 \\
\overline{46.90}\end{array}$ & $\begin{array}{l}3.55 \\
3.13 \\
- \\
3.51\end{array}$ & $\begin{array}{l}\text { Nannofossil marly chalk } \\
\text { Nannofossil marly chalk } \\
\text { (Interstitial water) } \\
\text { Sand }\end{array}$ \\
\hline $\begin{array}{l}4-1,5-8 \\
4-1,13-15 \\
4-1,24-28 \\
4-1,31-34\end{array}$ & $\begin{array}{l}602.05 \\
602.13 \\
602.24 \\
602.31\end{array}$ & $\begin{array}{l}2.142 \\
4.421 \\
4.922 \\
3.748\end{array}$ & $\begin{array}{l}1.988 \\
4.316 \\
- \\
-\end{array}$ & $\begin{array}{l}0.154 \\
0.105 \\
- \\
-\end{array}$ & $\begin{array}{l}7.75 \\
2.43 \\
- \\
-\end{array}$ & $\begin{array}{l}25 \\
25 \\
25 \\
25\end{array}$ & $\begin{array}{r}- \\
\overline{-} . \overline{336} \\
2.335\end{array}$ & $\begin{array}{l}1.986 \\
2.060 \\
- \\
-\end{array}$ & $\begin{array}{r}21.91 \\
4.73 \\
3.66 \\
4.61\end{array}$ & $\begin{array}{r}42.16 \\
9.44 \\
8.28 \\
10.43\end{array}$ & $\begin{array}{r}3.95 \\
8.89 \\
11.50 \\
8.75\end{array}$ & $\begin{array}{l}\text { Mudstone } \\
\text { Porcellanite } \\
\text { Limestone breccia } \\
\text { Conglomerate }\end{array}$ \\
\hline $\begin{array}{l}5-1,30-32 \\
5-1,56-58\end{array}$ & $\begin{array}{l}754.30 \\
754.56\end{array}$ & $3 . \overline{861}$ & $\begin{array}{l}1.717 \\
3.466\end{array}$ & $0 . \overline{395}$ & $1 \overline{11.40}$ & $\begin{array}{l}25 \\
26\end{array}$ & - & $\begin{array}{l}1.801 \\
2.102\end{array}$ & $\overline{8.25}$ & $\overline{16.80}$ & $\begin{array}{l}3.09 \\
7.29\end{array}$ & $\begin{array}{l}\text { Laminated siltstone } \\
\text { Porcellanite }\end{array}$ \\
\hline $\begin{array}{l}6-1,23-25 \\
6-2,18-20 \\
6-2,140-150 \\
6-3,16-18\end{array}$ & $\begin{array}{l}891.23 \\
892.68 \\
893.95 \\
894.16\end{array}$ & $\begin{array}{r}1.886 \\
1.897 \\
- \\
1.868\end{array}$ & $\begin{array}{l}1.767 \\
1.767 \\
-\overline{805} \\
1.805\end{array}$ & $\begin{array}{c}0.119 \\
0.130 \\
- \\
0.063\end{array}$ & $\begin{array}{l}6.73 \\
7.36 \\
- \\
3.49\end{array}$ & $\begin{array}{l}25 \\
26 \\
- \\
26\end{array}$ & $\begin{array}{c}- \\
- \\
2.100\end{array}$ & $\begin{array}{l}2.052 \\
2.024 \\
- \\
-\end{array}$ & $\begin{array}{l}20.58 \\
20.89 \\
19.25 \\
21.24\end{array}$ & $\begin{array}{r}40.92 \\
40.97 \\
-\quad \\
43.22\end{array}$ & $\begin{array}{l}3.63 \\
3.58 \\
- \\
3.79\end{array}$ & $\begin{array}{l}\text { Laminated mudstone } \\
\text { Mudstone (dark green) } \\
\text { (Interstitial water) } \\
\text { Laminated siltstone }\end{array}$ \\
\hline
\end{tabular}

${ }^{\mathrm{a}}$ The calculation used the following parameters: $\rho_{\mathrm{g}}, \rho_{\mathrm{gc}}=2.7 \mathrm{~g} / \mathrm{cm}^{3} ; \rho_{\mathrm{f}}=1.025 \mathrm{~g} / \mathrm{cm}^{3} ; \rho_{\mathrm{fc}}=1.128 \mathrm{~g} / \mathrm{cm}^{3} ; \mu=0.1028 \mathrm{~cm} 2 / \mathrm{g}$

${ }^{\mathrm{b}}$ Porosity $=[($ salt-corrected wet-water content $) /($ wet-bulk density $)] /$ (interstitial-water density); assumed salinity $=45^{\circ} \%$; interstitial-water density $=1.032 \mathrm{~g} / \mathrm{cm}^{3}$. 


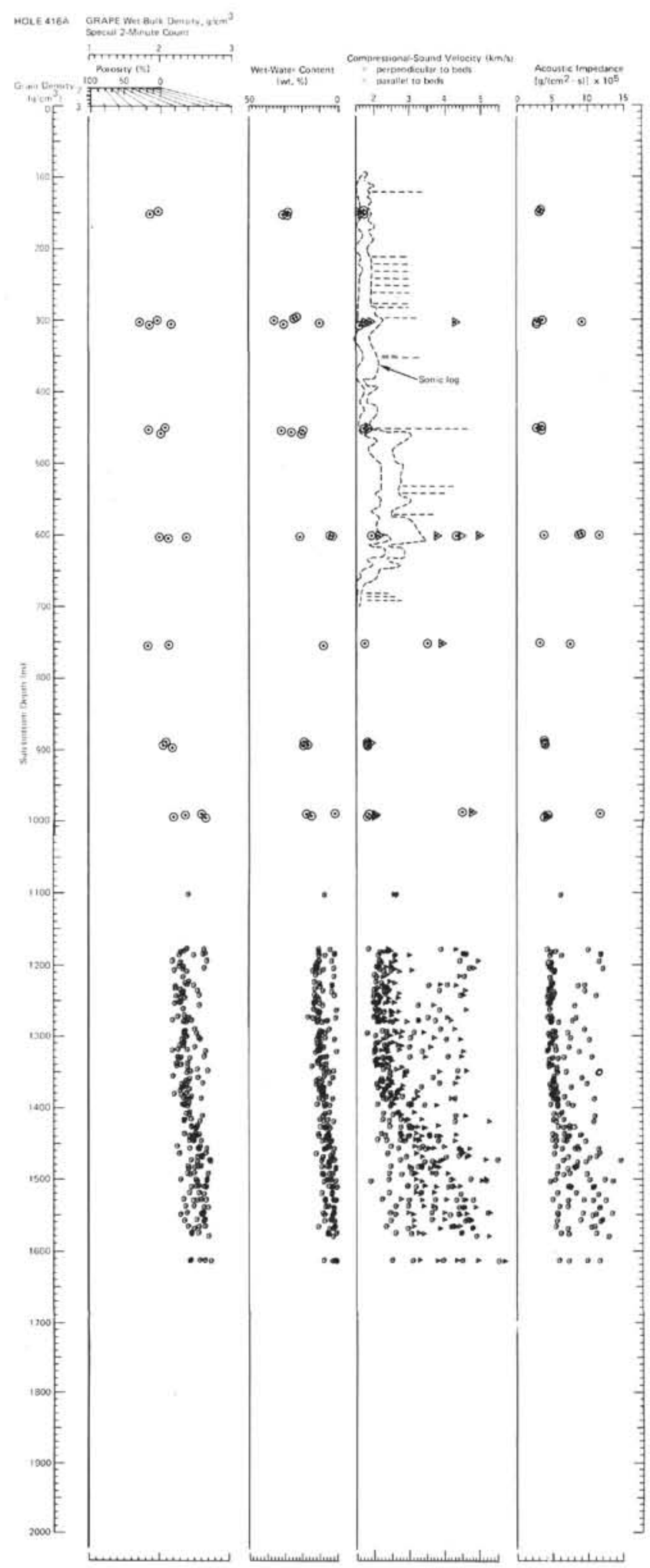

Figure 40. Physical properties and logging data versus depth, Site 416.

2. The second layer comprises upper-Oligocene through Pliocene sandstone, siltstone, mudstone, minor porcellanite, and interbedded diatom-rich nannofossil marl and ooze (in the Oligocene-Miocene section) from
100 to 457 meters sub-bottom. This layer has an in situ interval velocity of $1.69 \mathrm{~km} / \mathrm{s}$.

3. Layer three comprises early- and middle-Eocene and upper-Oligocene mudstone, siltstone, sandstone, and rare porcellanite from 457 to 642 meters sub-bottom. This layer has an in situ interval velocity of 2.26 $\mathrm{km} / \mathrm{s}$.

4. Layer four consists of lower- to middle-Eocene nannofossil marlstone from 642 to 661 meters subbottom, with an in situ interval velocity of $1.68 \mathrm{~km} / \mathrm{s}$.

5. Layer five consists of lower-Aptian through lowerto middle-Eocene claystone, with some limestone, sandstone, and siltstone, from 661 to 880 meters subbottom. This layer has an in situ interval velocity of 1.93 $\mathrm{km} / \mathrm{s}$.

6. Layer six consists of Valanginian to lower-Aptian sandstone, siltstone, and mudstone, from 880 to 1430 meters sub-bottom. This layer has an in situ interval velocity of $2.61 \mathrm{~km} / \mathrm{s}$.

7. Layer seven consists of Tithonian to Valanginian sandstone, siltstone, marlstone, and limestone, from 1430 to 1624 meters sub-bottom, with an in situ interval velocity of $3.75 \mathrm{~km} / \mathrm{s}$.

The interval velocities for Layers 1, 5, 6, and 7 are only approximations. These velocities are based on estimated percentages of different lithologies and assumed salinities. The calculated interval velocities were corrected for porosity rebound of the samples when removed from the sea floor, and for temperature and hydrostatic pressure, as discussed in Boyce (1976), but corrections due to grain-to-grain overburden pressure were not made. Details of these calculations are in Boyce (this volume).

Acoustic anisotropy in Miocene clastics, from 100 to 300 meters sub-bottom, is typically 0 to 2 per cent, whereas Oligocene to Paleocene sediments from 300 to 661 meters sub-bottom have velocities typically 0 to 4 per cent faster (range $0-11 \%$ ) horizontally than vertically. The Albian to late-Hauterivian sediments from 661 to 1178 meters sub-bottom have an anisotropy of 4 to 11 per cent, 8 per cent being typical. The middle-Hauterivian to Kimmeridgian beds from 1178 to 1624 meters sub-bottom (total depth) have an acoustic anisotropy of 0 to 30 per cent, 10 to 20 per cent being typical.

As a generality, the beds with the greatest absolute acoustic anisotropy have velocities between 2.0 and 4.1 $\mathrm{km} / \mathrm{s}$, and in some of these samples a typical absolute anisotropy is about $0.4 \mathrm{~km} / \mathrm{s}$. Cretaceous mudstone is in the 2.0 to $2.5 \mathrm{~km} / \mathrm{s}$ velocity range; thus, the mudstone tends to have the highest percentage anisotropy. Samples with velocities greater than $4.2 \mathrm{~km} / \mathrm{s}$ typically have a small anisotropy. These samples tend to be highvelocity sandstone and limestone which have become more isotropic as a result of complete cementation (see Boyce, this volume).

The anisotropy may be caused by any combination of: (1) foliation, (2) alignment of platy minerals with bedding (few gaps between minerals in a horizontal direction), (3) alternation of high- and low-velocity laminae, and (4) acoustic anisotropy of individual minerals. 
Other laboratory physical-properties data will not be discussed in the text, because their variations can be studied best in the graphs and tables provided.

\section{Well Logging}

The following Schlumberger well-logging tool combinations were run from about 97 meters to about 692 meters sub-bottom (except the temperature log, which stopped at 459 meters) in Hole $416 \mathrm{~A}$ :

1. Gamma ray (GR), borehole compensated sonic (BHC), and caliper ${ }^{4}$; (Figure 42).

2. GR, formation density compensated (FDC), compensated neutron log (CNL); (Figure 43).

3. GR, dual induction log (DIL), and Laterolog-8 (LL-8); (Figure 44). 45).

4. High-resolution temperature log (HRT); (Figure

Because the BHC was not centered in the hole, the measured velocities occasionally may have artificial high- or low-velocity spikes. According to Lynch (1962), these high-velocity spikes are caused by noise, and the low-velocity spikes by "cycle skipping." Thus, the integrated-travel-time marks on the log may not be accurate.

Because the eccentralizer at the bottom of the GDC-CNL tool collapsed, the FDC-CNL tool was not held securely against the side of the hole, and it perhaps oscillated from one side of the hole to the other. As a result, the FDC-CNL data are inconsistent and not quantitatively reliable.

The CNL is designed for rocks with less than 65 per cent porosity, and when porosities are greater than 65 per cent, the CNL data plot as a uniform vertical line at 65 per cent. When the tool is not held against the borehole, it becomes saturated, even though the porosity of the formation is less than 65 per cent, because the bore hole is recorded as added porosity.

The HRT measured a temperature of $3.15^{\circ} \mathrm{C}$ at the sediment surface, and the temperature gradually increased to $17.4^{\circ} \mathrm{C}$ at 425 meters. The average temperature gradient over this interval was $+3.0^{\circ} \mathrm{C}$ per 100 meters, but there were some minor changes in the slope of the curve. The HRT would not freely pass a blockage at 459 meters. Temperature measurements below 425 meters have a few sharp changes in slope which may be artifacts, probably caused by the HRT sticking in the hole from time to time. The measured temperatures are probably slightly lower than the actual (pre-drilling) in situ temperatures, because of the cooling effects of the water circulated during drilling.

Sound velocities recorded on the Schlumberger logs compare well with velocities measured on specimens in the laboratory. The laboratory velocities all fall within the range of the velocities shown on the Schlumberger logs. Precise comparison of the velocities is not possible, because of the small lengths $(2 \mathrm{~cm})$ of the samples

\footnotetext{
4 The caliper was not successful, because a flange to which the caliper arms attach would not pass through a 3-15/16 (10.0-cm) constriction in the core-barrel latch sleeve in the bottom-hole assembly.
}

measured in the laboratory, compared to the meter-long sampling interval of the BHC sonic tool (the heave of the ship accounts in part for the large sampling increment of the BHC). The FDC density data are not quantitative at this site; therefore, a statistical comparison of log velocity versus density cross plots of the laboratory velocity versus density data is not possible.

As a test to be certain that the FDC indeed was not functioning properly, a comparison with laboratory data and the electric-log data was made. A comparison of the laboratory velocity-density cross-plots of the "artificial" FDC and BHC sonic data confirms that the FDC values are not correct and are too low. The porosity-density derived from the electric log also indicated that the FDC data are too low. In this calculation, we assume a $2.7 \mathrm{~g} / \mathrm{cm}^{3}$ grain density and use Archie's (1942) formation factor-porosity relationship 5 . We also use the salinity derived from the laboratory interstitialwater sample, and the resistivity-salinity of sea water from Thomas et al. (1934). For example, the FDC indicated a $1.5-\mathrm{g} / \mathrm{cm}^{3}$ density at 147 meters, while the electric-log data indicate $1.80-\mathrm{g} / \mathrm{cm}^{3}$ density. At 493 meters, the FDC is about $1.78 \mathrm{~g} / \mathrm{cm}^{3}$, but the electriclog data (and laboratory density-velocity cross-plots) indicate a density of about $2.1 \mathrm{~g} / \mathrm{cm}^{3}$.

At Site 416, the geologic section from 97 to 692 meters can be separated into 3 major intervals based on the Schlumberger log data. (In the upper section, the FDC and CNL Logs are not quantitative and therefore are not used here.) The first major interval is from 97 meters (top of logs) to 457 meters and is characterized by low velocity and density. The gamma-ray values irregularly increase with depth, suggesting alternating sandstone, mudstone, nannofossil marls, and nannofossil chalks. Velocities in the interval from 97 to 187 meters are irregular, but show a subtle increase with depth, from 1.6 to $1.68 \mathrm{~km} / \mathrm{s}$. Below 187 meters, velocities are typically $1.68 \mathrm{~km} / \mathrm{s}$. The interval velocity between 97 and 457 meters, derived from the integrated travel time and logging depth, is $1.69 \mathrm{~km} / \mathrm{s}$. Porosity from the electric log is slightly irregular, but typically about 54 per cent $\left(1.8 \mathrm{~g} / \mathrm{cm}^{3}\right)$.

The interval from 457 to 642 meters is distinct from the adjacent sections in having high velocities and densities and a medium GR count. The GR count decreases from the overlying section, suggesting that there are more coarse clastics (sand-silt) to dilute the clay fraction. The general lithology suggested from the cores, irregular GR counts, and irregular velocity data, is an alternation of mudstone, siltstone, sandstone, and porcellanite (relatively high velocity). The velocities are typically $2.26 \mathrm{~km} / \mathrm{s}$, but range from $1.5($ ?) to $4.0 \mathrm{~km} / \mathrm{s}$. Nonetheless, an interval velocity of $2.03 \mathrm{~km} / \mathrm{s}$ is derived from the integrated travel time and the logging depths, which is significantly lower than the $2.26-\mathrm{km} / \mathrm{s}$ figure. Again, cycle skipping or noise (Lynch, 1962) may render the $2.03-\mathrm{km} / \mathrm{s}$ velocity value incorrect. Typical porosity

\footnotetext{
${ }^{5} R_{\mathrm{o}} / R_{\mathrm{w}}=F=\theta^{-2}$, where $R_{\mathrm{o}}$ is formation resistivity, $R_{\mathrm{w}}$ is interstitial water resistivity, and $\theta$ is the fractional porosity.
} 

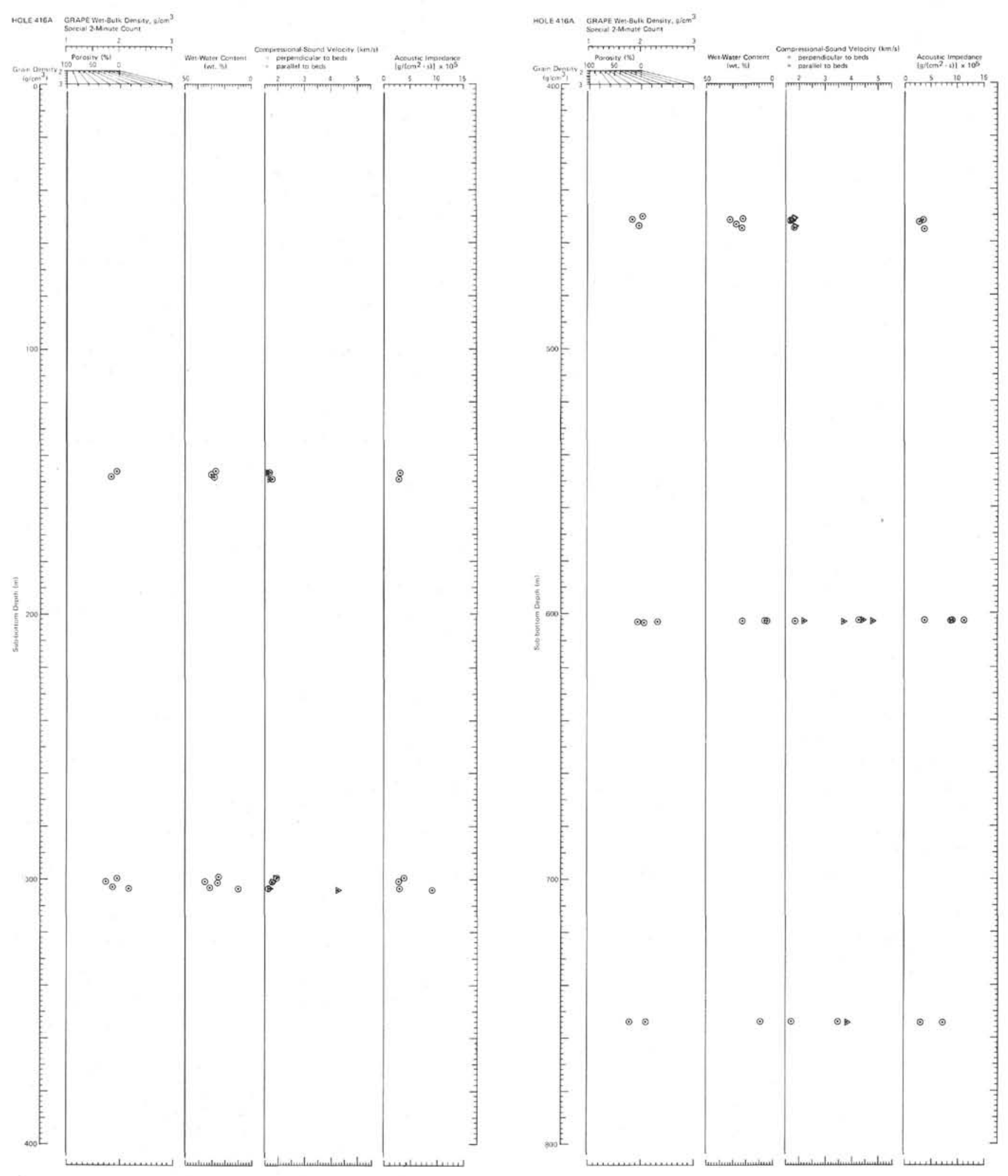

Figure 41. Data of Figure 40 at a larger scale. 

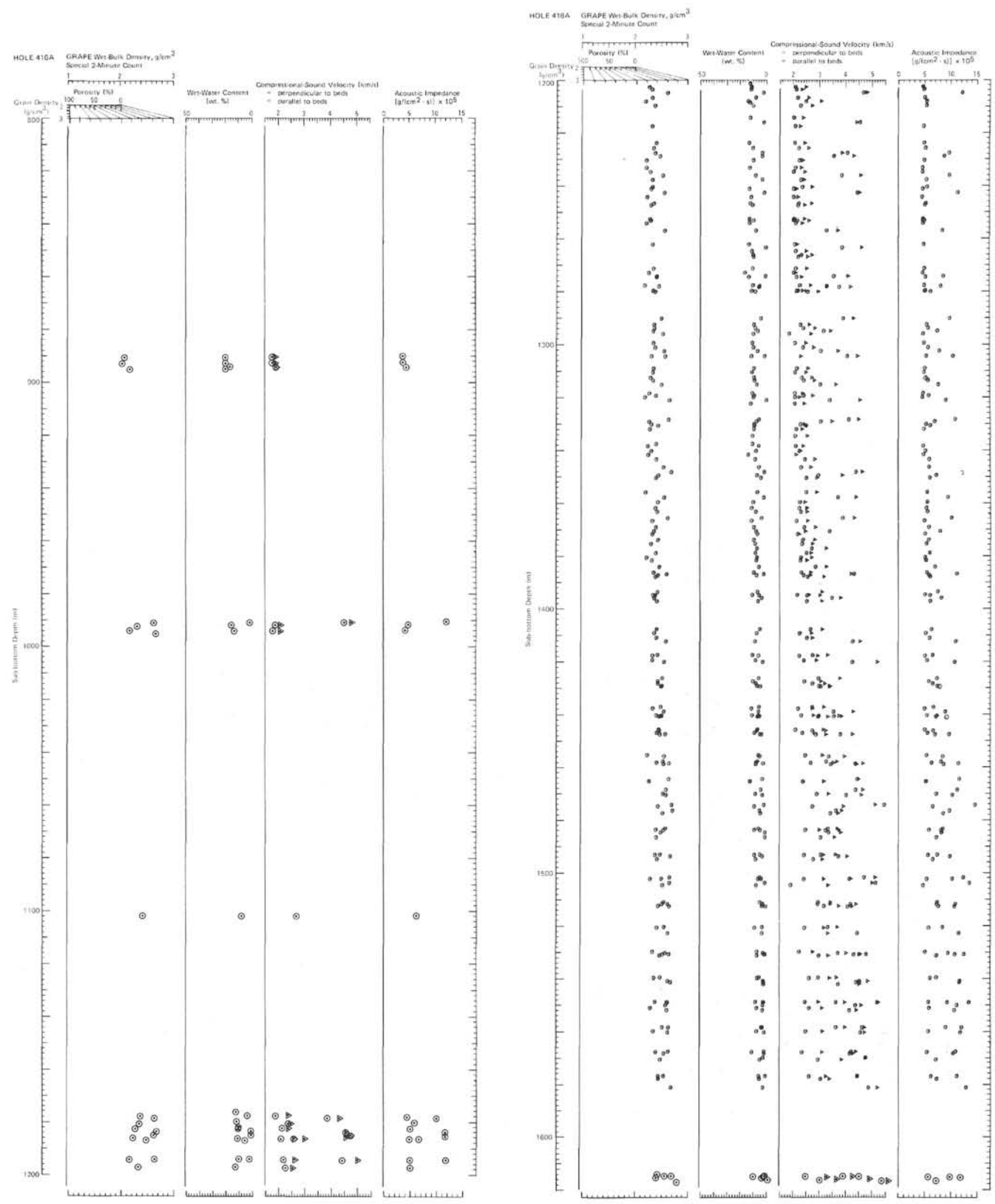

Figure 41. (Continued). 


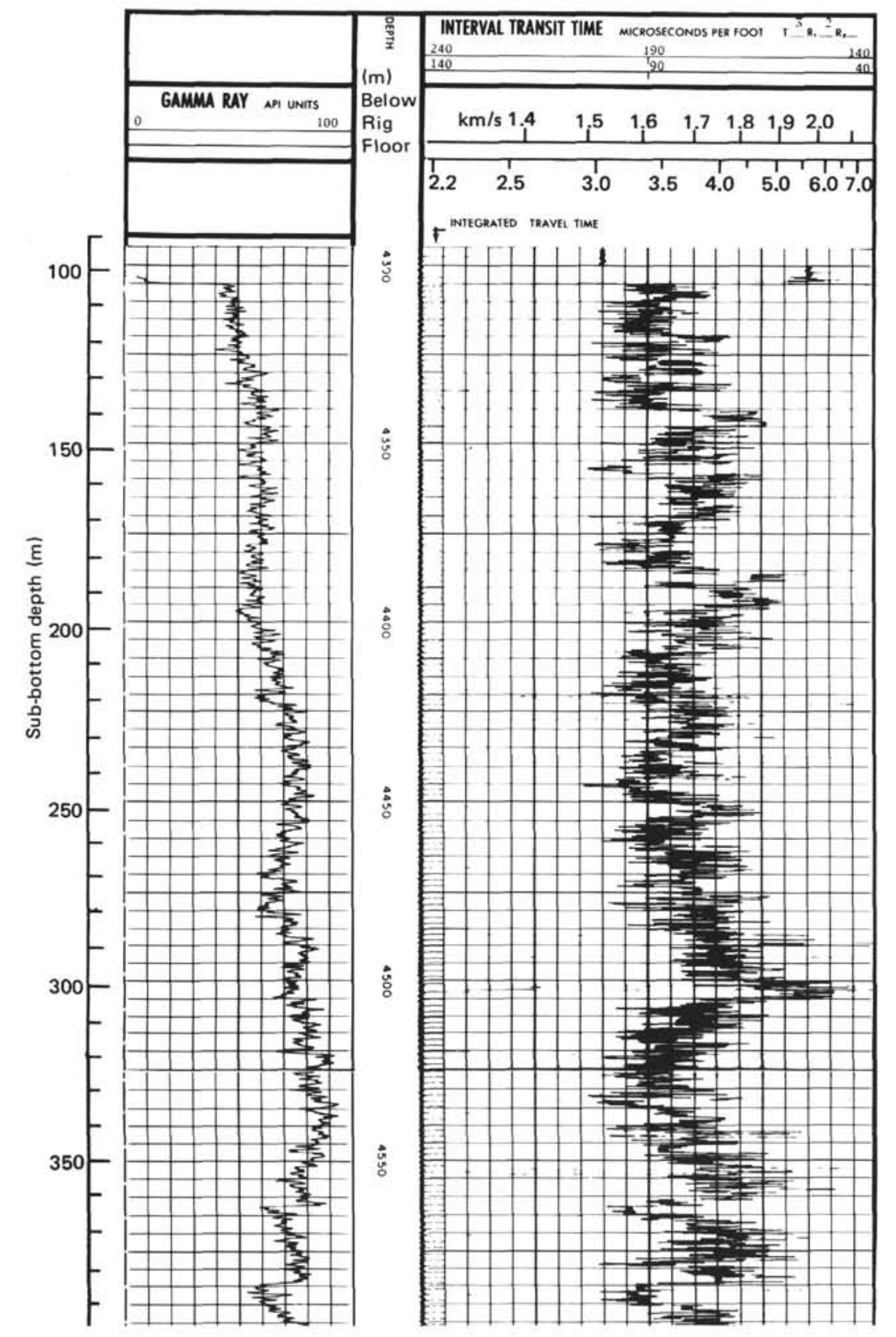




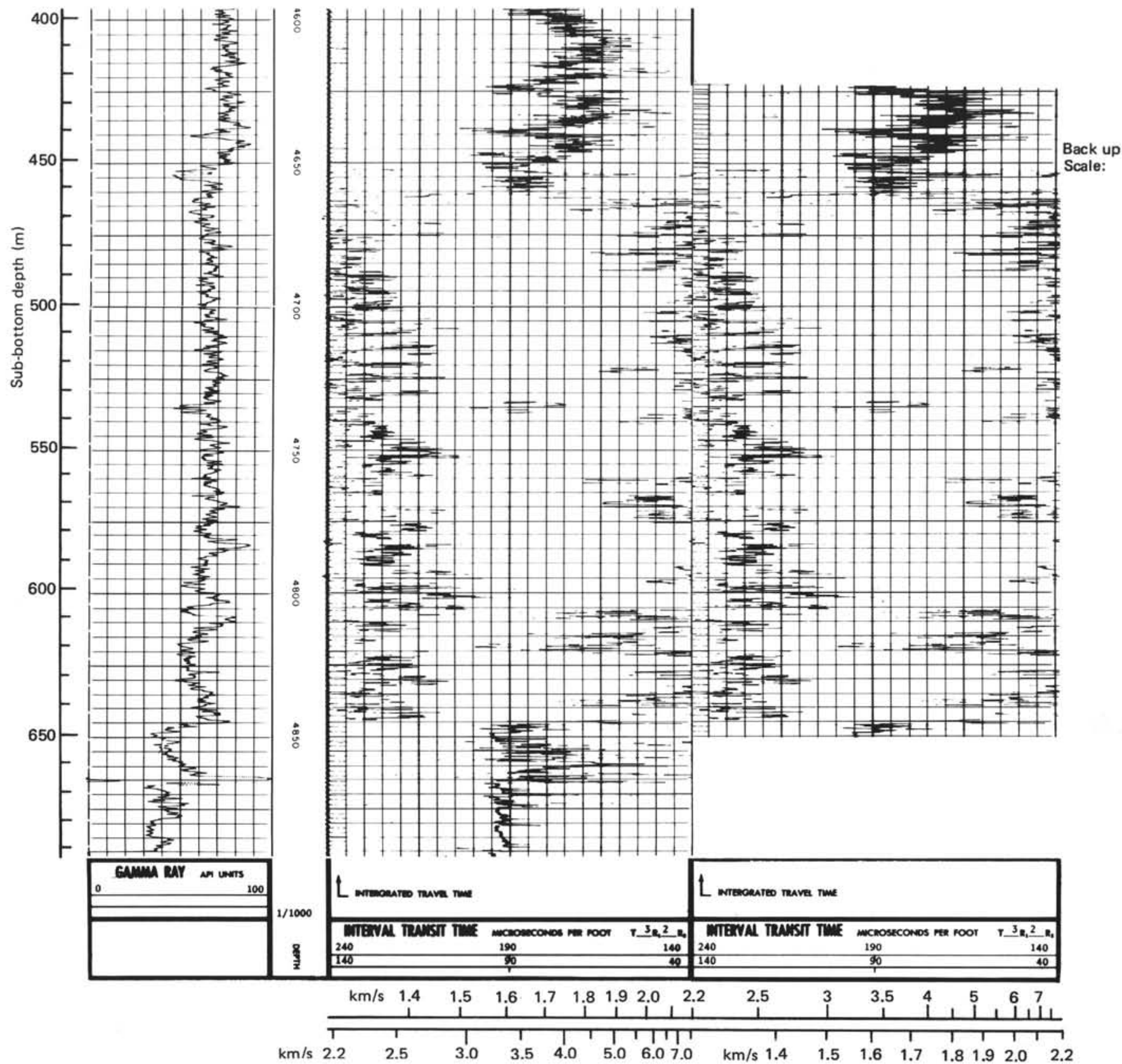




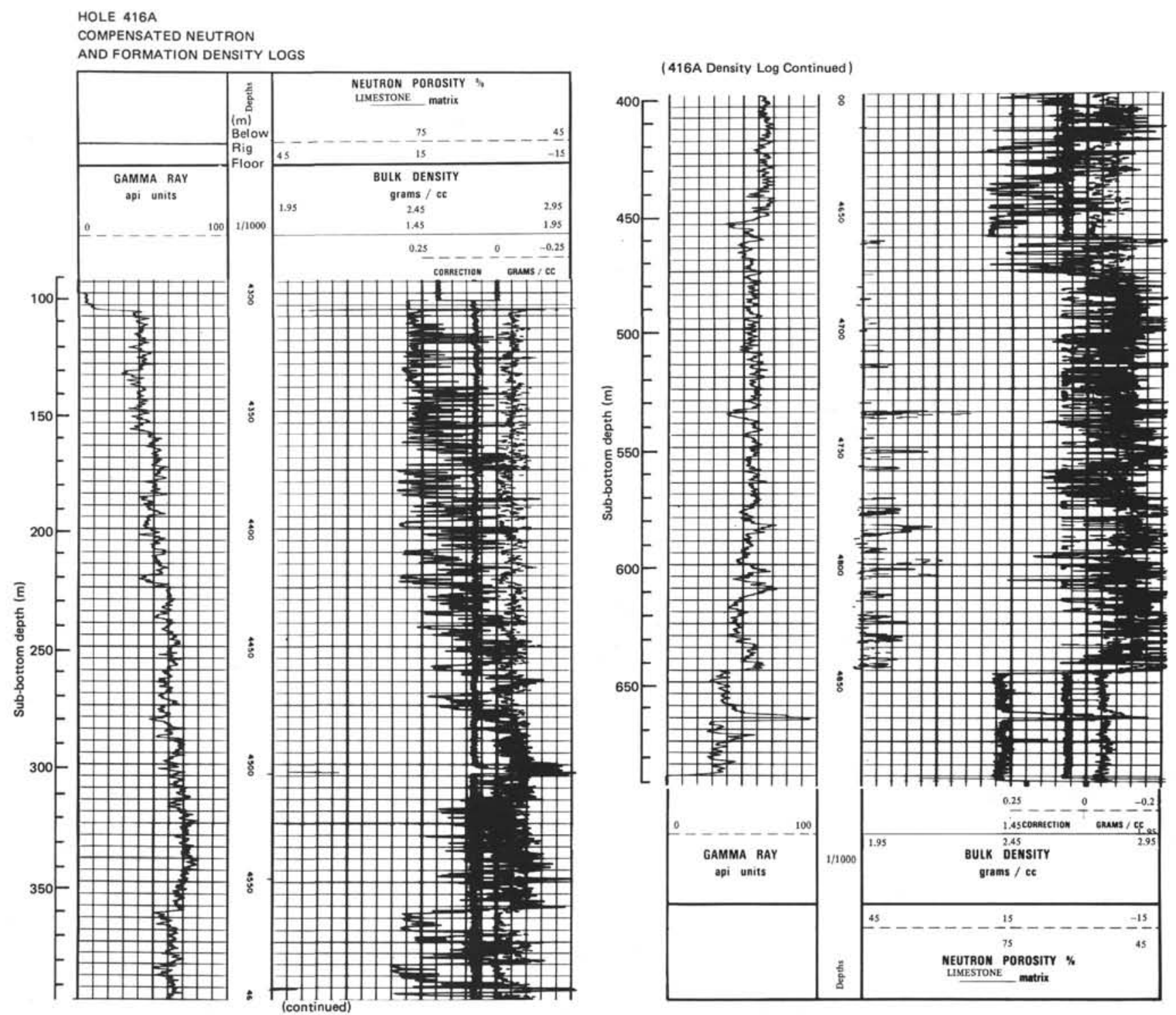

Figure 43. Compensated neutron-formation-density log and gamma-ray log of Hole 416A. At 4350 meters, the three curves on the large graph are, from left to right (1) density, (2) neutron, and (3) correction applied to density log. The eccentralizing spring collapsed; thus, these data are not quantitative. The density values are low and the porosity values are high. Approximate depth below sea floor is the depth on the log minus water depth (4193 meters) and minus 10 meters.

and density indicated by the electric log are 37 per cent and $2.1 \mathrm{~g} / \mathrm{cm}^{3}$, respectively.

The interval from 642 to 692 meters (bottom of log data) can be distinguished from the overlying section by lower velocities, densities, and gamma radiation. The lower gamma radiation suggests marlstone and nannofossil-bearing claystone, which in general have a lower clay content, or perhaps the frequency of non-clayey beds is greater than in the overlying section. A high GR spike may indicate a hiatus or condensed section which may have caused concentration of radioactive diagenetic minerals. Sound velocities are about $1.65 \mathrm{~km} / \mathrm{s}$, and the porosity and density derived from the electric $\log$ are typically 65 per cent and $1.68 \mathrm{~g} / \mathrm{cm}^{3}$, respectively.

\section{BIOSTRATIGRAPHY}

\section{Biostratigraphic Summary}

The section penetrated at Site 416 was sparsely cored from the sea floor to a sub-bottom depth of 1176 meters, and continuously cored below 1176 meters. Because of the drilling technique used while taking the widely spaced cores of the upper 1100 meters, the locations of these cores are uncertain and are commonly higher than the nominal levels indicated in the coring summary (Table 1) and on the core-description sheets at the end of this chapter. However, results from Site 370,1.2 miles to the east, provide data by which to estimate the actual location of the samples and to define plausible stratigraphic boundaries. A detailed comparison of the two sites is 

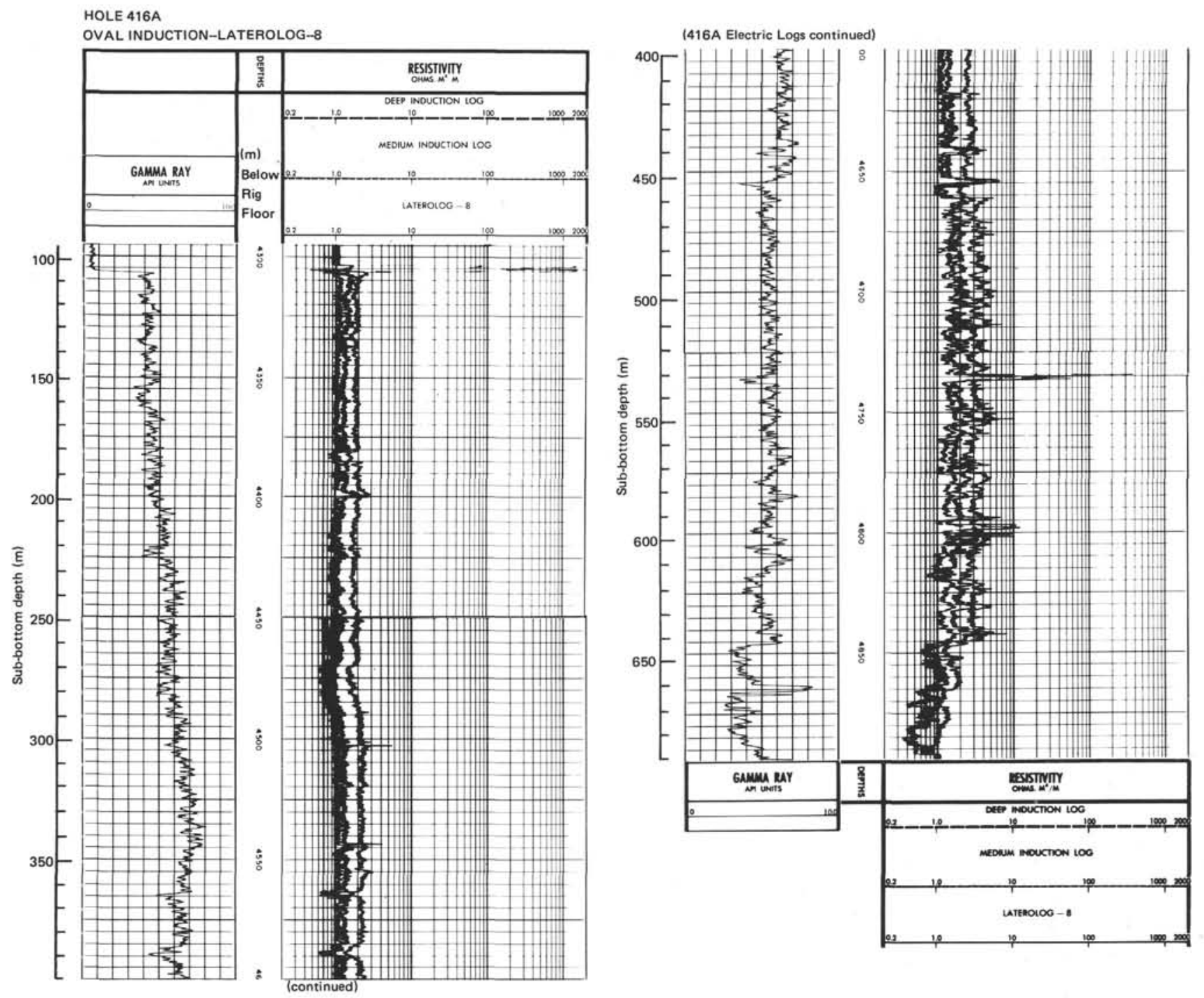

Figure 44. Dual induction-Laterolog-8 and gamma-ray log of Hole 416A. At 4350 meters, the three curves on the resistivity graph are, from left to right (1) deep induction, (2) medium induction, (3) and Laterolog-8. Approximate depth below sea floor is equal to the depth on the log minus 10 meters and minus water depth $(4193$ meters).

given in the following sedimentation-rate section, and a composite sequence for Sites 416 and 370 is represented on Figure 46.

The 1624-meter-thick sedimentary section represents a sequence from Pleistocene to Tithonian, with a substantial hiatus of about $40 \mathrm{~m} . \mathrm{y}$. from the Late Cretaceous through the earliest Paleocene, a hiatus of lesser importance encompassing part of the late Eocene and probably all of the early Oligocene, and two minor hiatuses - one spanning the Pliocene/Pleistocene boundary and the other the Paleocene/Eocene boundary.

The section comprises (from top to bottom):

1. About $45 \mathrm{~cm}$ of upper-Pleistocene nannofossil ooze (upper $45 \mathrm{~cm}$ of Core 416-1) which contains abundant and well-preserved calcareous plankton and rare fragmented radiolarians. This veneer of Pleistocene sediment unconformably overlies sediments of the lower upper Pliocene. The extent of the hiatus is about 1 m.y.
2. About 77.5 meters $(0.45-78 \mathrm{~m})$ of Pliocene and upper Miocene nannofossil marl and ooze (remainder of Core 416-1 and upper $90 \mathrm{~cm}$ of Core 416A-1), which contains abundant, moderately to poorly preserved foraminifers (more poorly preserved in the Pliocene than in the upper Miocene); abundant, well- to moderately wellpreserved nannofossils; and rare, fragmented radiolarians. Some reworked Cretaceous and Eocene fossils were observed.

3. About 349.5 meters $(78-427.5 \mathrm{~m})$ of middleMiocene through uppermost lower-Oligocene turbidite beds, consisting of graded sequences of sandstone and diatom-rich nannofossil marl and chalk (remainder of Core 416A-1 and Cores 416A-2 and 3). Nannofossils are abundant and well preserved in the middle Miocene, common and poorly to moderately well preserved in the lower Miocene, and rare and poorly preserved in the upper Oligocene. Foraminifers are rare and poorly to moderately well preserved in the marl and chalk layers, 

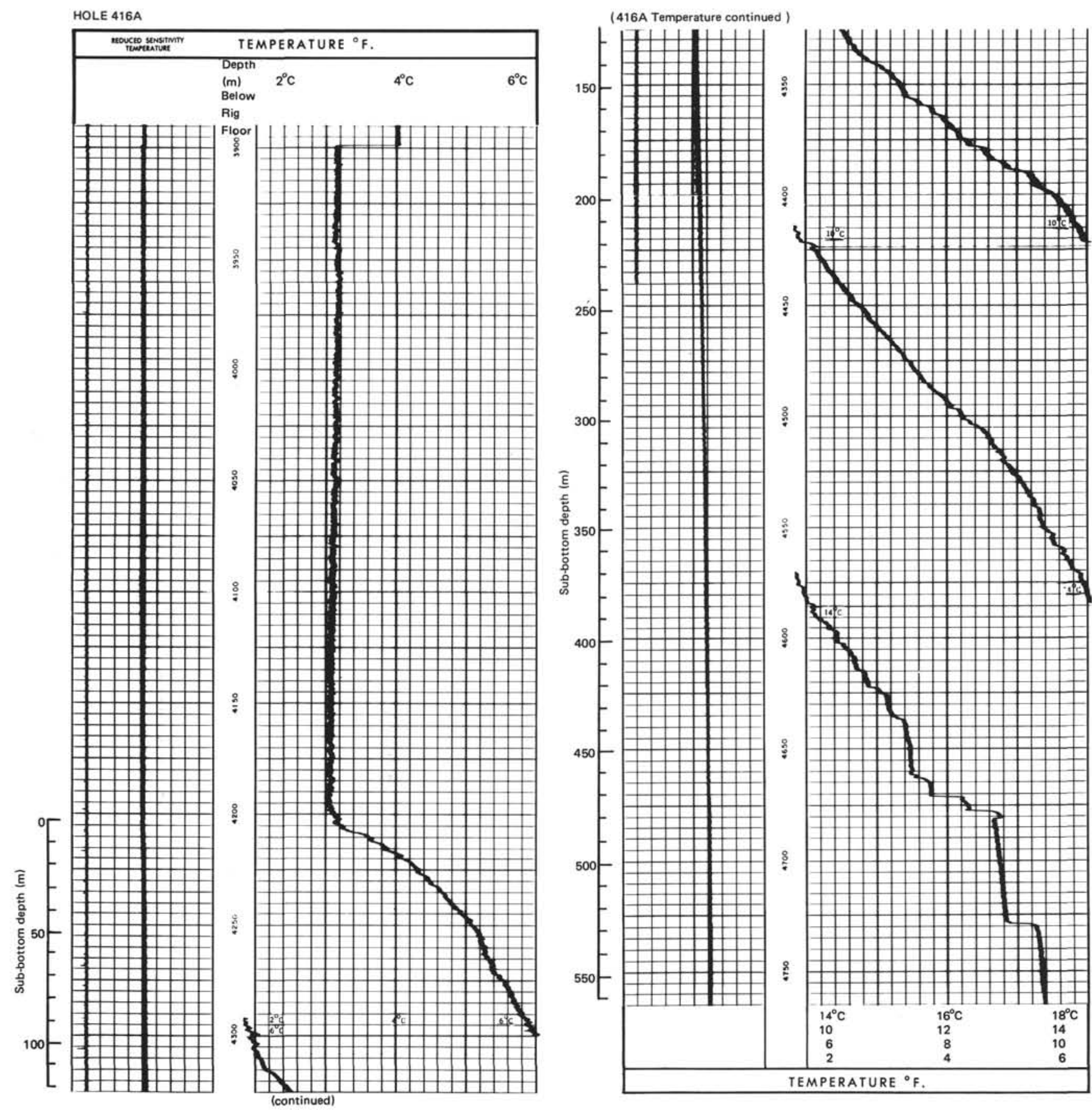

Figure 45. High-resolution temperature log of Hole 416A (1) in the open hole and (2) through the cone and casing and drill string. Approximate depth below or above the sea floor is equal to the depth on the log minus 10 meters and minus water depth (4193 meters).

whereas they are common and well to moderately well preserved in the basal sand layers. Radiolarians are rare to common and moderately well preserved in the Miocene, whereas they are rare and fragmented in the upper Oligocene. Reworked Cretaceous fossils occur in the Oligocene of Core 416A-3.

4. A 17.5-meter-thick, highly condensed section (427.5$445 \mathrm{~m}$ ) encompassing the upper Eocene and most of the lower Oligocene, with a probable hiatus. This interval was not cored at Site 416 .

5. About 197 meters (445-642 m) of Eocene turbidites, consisting of graded sequences of mudstone, siltstone, sandstone, and gravel. Cores 416A-4 and the upper $50 \mathrm{~cm}$ of Core $416 \mathrm{~A}-5$ are middle to early Eocene; they both contain rare to common nannofossils that are poorly to moderately well preserved, and rare, poorly 


\begin{tabular}{|c|c|c|c|c|}
\hline Series & $\begin{array}{l}\text { Cores, } \\
\text { Site } 370\end{array}$ & $\begin{array}{l}\text { Cores, } \\
\text { Site } 416\end{array}$ & 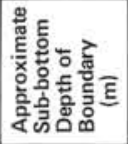 & $\begin{array}{l}\text { Basis for Boundary } \\
\text { Position }\end{array}$ \\
\hline \multirow{2}{*}{ Pleistocene } & \multirow{2}{*}{$370-1$} & $\begin{array}{l}416-1-1 \text { (top) } \\
416-1-1,42 \mathrm{~cm}\end{array}$ & \multirow[t]{2}{*}{0.45} & \multirow[t]{2}{*}{$\begin{array}{l}\text { Boundary between } \\
\text { NN } 21 \text { and NN } 16\end{array}$} \\
\hline & & $\begin{array}{l}416-1-1,45 \mathrm{~cm} \\
416 \mathrm{~A}-1-1,30 \mathrm{~cm}\end{array}$ & & \\
\hline \multirow{2}{*}{ Upper Miocene } & \multirow{2}{*}{$370-2$} & $416 \mathrm{~A}-1-1,31 \mathrm{~cm}$ & 35 & $\begin{array}{l}\text { Inferred from average sedimentation } \\
\text { rates at Site } 370\end{array}$ \\
\hline & & $416 \mathrm{~A}-1-1,90 \mathrm{~cm}$ & \multirow{2}{*}{78} & \multirow{2}{*}{$\begin{array}{l}\text { Inferred from average sedimentation } \\
\text { rates at Site } 370\end{array}$} \\
\hline \multirow{2}{*}{ Middle Miocene } & \multirow{2}{*}{$370-3$} & $416 \mathrm{~A} \cdot 1-191 \mathrm{~cm}$ & & \\
\hline & & $416 \mathrm{~A} \cdot 1-2$ & \multirow{2}{*}{150} & \multirow{2}{*}{$\begin{array}{l}\text { Inferred from average sedimentation } \\
\text { rates at Site } 370\end{array}$} \\
\hline \multirow{2}{*}{ Lower Miocene } & \multirow{2}{*}{370.4} & \multirow{2}{*}{$\begin{array}{l}416 \mathrm{~A} \cdot 1, \mathrm{CC} \\
416 \mathrm{~A} \cdot 2\end{array}$} & & \\
\hline & & & \multirow{2}{*}{285} & \multirow{2}{*}{$\begin{array}{l}\text { Inferred from average sedimentation } \\
\text { rates at Site } 370 .\end{array}$} \\
\hline $\begin{array}{l}\text { Upper } \\
\text { Oligocene }\end{array}$ & 370.5 & $416 A-3$ & & \\
\hline \multirow{2}{*}{$\begin{array}{c}\text { Lower Oligocene } \\
\text { to } \\
\text { Upper Eocene }\end{array}$} & \multirow{2}{*}{$370-6$} & \multirow[b]{2}{*}{ None } & 400 & $\begin{array}{l}\text { Inferred from average } \\
\text { sedimentation rate at Site } 370\end{array}$ \\
\hline & & & \multirow{2}{*}{445} & \multirow{2}{*}{ Highest NP 16-NP 17 sample } \\
\hline Middle Eocene & $\begin{array}{c}370 \cdot 7 \\
370.15\end{array}$ & \multirow[t]{2}{*}{$416 \mathrm{~A} \cdot 4$} & & \\
\hline \multirow{2}{*}{ Lower Eocene } & $370-16$ & & 600 & $\begin{array}{l}\text { Inferred from average } \\
\text { sedimentation rate at Site } 370\end{array}$ \\
\hline & $370-18-2,77 \mathrm{~cm}$ & 416A-5.1 & 642 & Inferred from gamma-ray log \\
\hline Upper Paleocene & $37-18, \mathrm{CC}$ & & & \\
\hline Lower Paleocene & $370-19, \mathrm{CC}$ & TNone & 050.5 & Lowest P3 sample \\
\hline Albian & $370-20$ & & 661 & Inferred from gamma-ray log \\
\hline Aptian & $370-32$ & 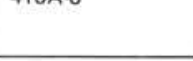 & 844 & Lowest $C$. litterarius Zone sample \\
\hline Barremian & $\begin{array}{l}370-33 \\
370-34\end{array}$ & None & & \\
\hline & & & 885 & Top C. cuvillieri \\
\hline Hauterivian & $\begin{array}{l}370-35 \\
370-51\end{array}$ & $\begin{array}{l}416 A-7 \\
416 A-13\end{array}$ & & Bottom D. hauteriviana \\
\hline Valanginian & & 416A-14 & 1222 & $\begin{array}{l}\text { Bottom L. ouachensis multicella } \\
\text { Bottom L. hauteriviana cylindrica }\end{array}$ \\
\hline Valangmian & & $416 \mathrm{~A} \cdot 48$ & 1539 & Boundary between $C$. angustiforatus (?) \\
\hline Berriasian & None & $416 \mathrm{~A}-49$ & & and N. colomii Zones \\
\hline & & $416 \mathrm{~A} \cdot 53 \cdot 2,26 \mathrm{~cm}$ & 1579 & Bottom P. asper \\
\hline Tithonian & & $\begin{array}{l}416 \mathrm{~A}-53-2,45 \mathrm{~cm} \\
416 \mathrm{~A}-57\end{array}$ & & Bottom common P. senarta \\
\hline
\end{tabular}

Figure 46. Stratigraphic series at Sites 416 and 370.

preserved foraminifers. Some levels are barren of foraminifers. Radiolarians are absent and were not found lower in the section.

6. At 642 meters, an unconformity was observed at Site 370. A short hiatus spans the Eocene/Paleocene boundary.

7. About 19 meters $(642-661 \mathrm{~m})$ of Paleocene claystone to marlstone, not cored at Site 416 .

8. Below this series, a substantial hiatus omits the lowermost Paleocene and the entire upper Cretaceous. The uppermost sediments below the hiatus in Core 416A-5, CC are not older than the Praediscosphaera cretacea nannofossil zone of the early Albian. Although Eiffellithus turriseiffeli is not present in this sample, the absence of this taxon could result from poor preservation. A lesser age is therefore not excluded for Core
416A-5, CC, and the presence of Parhabdolithus asper indicates an age no younger than Cenomanian. These data suggest that the hiatus extends from the Paleocene at least to the Cenomanian, and perhaps to the Albian, a time span of about 40 m.y.

9. About 224 meters $(661-885 \mathrm{~m})$ of nannofossil claystone and silty claystone (Cores 416A-5, CC and 416A-6) within an interval ranging from Barremian to Albian and containing extremely rare, poorly preserved foraminifers, and common, moderately to poorly preserved nannofossils.

10. About 739 meters (885-1624 m) of Hauterivian to Tithonian distal turbidites (Cores 7 to 57), which consist of both calcareous and quartzose cycles, from sand or siltstone to mudstone. This thick sequence contains rare, poorly preserved benthic foraminifers; rare to 
common nannofossils, which are poorly to moderatelywell preserved; and rare to common calpionellids in the lower Valanginian to Tithonian.

\section{Calcareous Nannoplankton}

\section{Pleistocene}

Pleistocene sediments were recovered only in the first $43 \mathrm{~cm}$ of 416-1. Nannofossils are abundant and wellpreserved. These assemblages of the Pleistocene belong to the Emiliania huxleyi Zone (NN 21), with Emiliania huxleyi. Neither Discoaster brouweri nor Pseudoemiliania lacunosa were identified. In both studied samples, reworked Cretaceous coccoliths and Tertiary discoasters were observed.

\section{Pliocene}

The two youngest nannoplankton zones of the Pliocene are missing in the sediments directly below the Pleistocene sediments in Core 416-1. Discoaster pentaradiatus, $D$. brouweri, and $D$. surculus were recognized in Sample 416-1-1, 45-46 cm, which indicates the early late Pliocene, D. surculus Zone (NN 16). Pseudoemiliania lacunosa was not found. Also, Reticulofenestra pseudoumbilica is missing, but this species is present in three samples from 416A-1-1, 7-8 cm to 416A-1-1, 21-22 $\mathrm{cm}$, corresponding to the late early Pliocene, $R$. pseudoumbilica Zone (NN 15).

The nannofossils of the Pliocene are abundant and relatively well preserved. Some fragmentation and restricted reworking of Cretaceous and Eocene nannofossils was noted.

\section{Late to Early Miocene}

Late- to early-Miocene floras were recovered from Core 416A-1 below $34 \mathrm{~cm}$ to the core catcher of 416A-2. Discoaster quinqueramus and Ceratolithus tricorniculatus were identified in a sample from the top (416A$1-1,34 \mathrm{~cm}$ to $416 \mathrm{~A}-1-1,86-87 \mathrm{~cm}$ ) of this stratigraphic level; they indicate a late-Miocene age, $D$. quinqueramus Zone (NN 11).

Discoaster exilis (first occurrence, lower limit) and Sphenolithus heteromorphus (last occurrence, upper limit) identify the middle Miocene, Sphenolithus heteromorphus Zone (NN 5), in samples from 416A-1-1, 93-94 $\mathrm{cm}$ to $416 \mathrm{~A}-1, \mathrm{CC}$.

In the Core $416 \mathrm{~A}-2$ sediments with Helicopontosphaera ampliaperta, $H$. parallela and Sphenolithus heteromorphus were recovered; which indicates an earlyMiocene age, encompassing the NN 3 to NN 4 zonal interval.

Calcareous nannoplankton of the late and middle Miocene is abundant with moderate to good preservation, but in the early Miocene nannoplankton is general ly common and preservation poor to moderate. Discoasters were observed with overgrowths and are partly fragmented; coccoliths are partly recrystallized.

\section{Oligocene}

Oligocene sediments were recovered in Core 416A-3. The poor preservation and the relatively low abundance of coccoliths in this core made age assignment difficult.
The middle to late Oligocene, Sphenolithus predistentus Zone to Sphenolithus ciperoensis Zone (NP 23-NP 25), was identified by the presence of Dictyococcites dictyodus (upper limit) and Sphenolithus distentus (lower limit); other marker species were not found.

The floras of Core 416A-4 show very poor preservation, with recrystallization and fragmentation; there is a low content of nannofossils. The floras contain Chiasmolithus grandis (upper limit) and Reticulofenestra umbilica (lower limit), which suggest the middle to late Eocene (NP 15-NP 20). The base of the Tertiary section in Core 416A-5-1, 34-35 cm contains a middle-Eocene nannoflora (Zones NP 13-NP 14), with Discoaster lodcensis (upper limit), which is common but poorly to moderately well preserved.

\section{Middle Albian to Cenomanian}

Sample 416A-5, CC contains common but poorly preserved coccoliths. The assemblage includes Prediscosphaera cretacea and Parhabdolithus asper, which indicate an age not older than middle Albian and not younger than Cenomanian. Eiffellithus turriseiffeli is not present in this sample. The absence of this taxon, however, could result from poor preservation (it is absent in one-third of the samples within the E. turriseiffeli zone at Site 370 ) and it does not therefore exclude an age younger than the middle-Albian $P$. cretacea Zone, even though the first appearance of $E$. turriseiffeli defines the upper limit of this zone. The presence of $P$. asper indicates that this sample could not be younger than Cenomanian.

\section{Early Aptian}

Early-Aptian sediments were recovered in Core 416A6 , CC. Nannofossils are few to common and moderately well preserved. This assemblage, with Chiastozygus litterarius, but without Parhabdolithus angustus, belongs to the $C$. litterarius Zone of the early Aptian.

\section{Late Hauterivian to Early Valanginian}

Core 416A-7 was taken at depths between 991.5 and 1090 meters; consequently it is impossible to determine the exact depth of the 4.5-meter-long core. Samples from 416A-7 to 416A-48-1, 86-87 cm contain coccolith assemblages which include the Cretaceous species Calcicalathina oblongata, Micrantholithus obtusus, Bipodorhabdus colligatus, Parhabdolithus asper, Diadorhombus rectus, and Cruciellipsis cuvillieri. This assemblage indicates a late-Hauterivian to early-Valanginian age (Lithraphidites bollii Zone to Cretarhabdus angustiforatus Zone), but the zonal species Lithraphidites bollii was not observed in the samples. Coccolith assemblages of this interval are rare to few and poorly to moderately well preserved. Coccolith dissolution was noted in many samples.

\section{Berriasian}

The top of the Berriasian is marked in Sample 416A49-1, 90-91 $\mathrm{cm}$ by the first occurrence of Bipodorhabdus colligatus, Diadorhombus rectus, and Calcicalathina oblongata, and its base in Sample 416A-53-2, $26 \mathrm{~cm}$ by the first occurrence of Parhabdolithus asper and the 
first common occurrence of Polycostella senaria. This interval belongs to the Nannoconus colomi Zone, which encompasses the entire Berriasian. Only rare and sporadic occurrences of the zonal species $N$. colomi were observed. Coccoliths in this interval are few to common and show poor to moderately good preservation. Coccolith dissolution was noted in more than half the samples.

\section{Tithonian}

Samples $416 \mathrm{~A}-53-2,45-46 \mathrm{~cm}$ to $416 \mathrm{~A}-57$, CC contain coccolith assemblages devoid of Cretaceous species, but including Cretaturbella rothii and Parhabdolithus embergeri. This assemblage indicates a Tithonian age, Parhabdolithus embergeri Zone. The nannofossils of the Tithonian are rare to few and poorly to moderately well preserved. Coccolith dissolution was observed in about half the samples, namely in the middle part of this stratigraphic interval.

\section{Foraminifers}

\section{Cenozoic}

Coarse-Fraction ( $>63 \mu \mathrm{m}$ ) Components, Abundance and Preservation of Foraminifers

Abundant foraminifers dominate the coarse fraction of the Pleistocene to upper-Miocene nannofossil marl and ooze (Core 416-1; 416 bit sample from about 20 meters; upper $90 \mathrm{~cm}$ of Core 416A-1). They are well preserved in the Pleistocene (upper $42 \mathrm{~cm}$ of Core 416-1) and moderately well to poorly preserved in PlioceneMiocene sediments. Signs of solution are more pronounced in Pliocene assemblages, as evidenced by the elimination of the crust of species of Sphaeroidinellopsis, a significant amount of fragmentation of planktonic tests, and a higher relative abundance of benthic species. Small, subangular quartz grains are common in Pleistocene and middle- and lower-Miocene sediments, and rare in Pliocene and upper-Miocene sediments. Glauconite is rare in the Pleistocene. Rare to common echinoderm fragments and rare ostracodes occur at some levels.

The middle- and lower-Miocene nannofossil marl, mud, and chalk (remainder of Core 416A-1 and Core 416A-2) yielded a small amount of coarse fraction which is dominated by siliceous biogenic components (radiolarians, sponge spicules, and diatoms), or at some levels by small, subangular quartz grains (especially in Core $416 \mathrm{~A}-1-2,31-33 \mathrm{~cm}$ ). Foraminifers are rare and poorly to moderately well preserved. Glauconite is rare to common. Fish and echinoderm fragments are rare. Chert and sandstone fragments occur in Core 416A-2.

The samples (only fine sediments were examined) examined from the Oligocene to Eocene marl, mud, marlstone, and mudstone (Cores $416 \mathrm{~A}-3$ to $416 \mathrm{~A}-5$ ) yielded an extremely small amount of coarse fraction which is almost entirely composed of sponge spicules and small, subangular quartz grains. Radiolarians and diatoms are common. Rare components include fish teeth, glauconite, and volcanic glass. Foraminifers are very rare, poorly preserved, and dominated by benthic species. Several levels are barren of foraminifers.

\section{Planktonic-Foraminifer Zonation}

The upper $42 \mathrm{~cm}$ of Core 416-1 are of late-Pleistocene age (N.23-N.22), as shown by common Globorotalia truncatulinoides and pink specimens of Globigerinoides ruber throughout this interval. G. truncatulinoides together with Globigerinoides sacculifer and $G$. ruber dominate the planktonic fauna. Globorotalia inflata is rare in the upper part of the interval $(28-30 \mathrm{~cm})$ and more common at its base $(40-42 \mathrm{~cm})$. The increase in abundance of $G$. inflata in the lower Pleistocene is simultaneous with an increase in the abundance of Globigerina bulloides and reflects water conditions colder than those which prevailed during deposition of the uppermost sediments.

The remainder of Core 416-1 and the bit sample from about 20 meters contain common forms transitional between Globorotalia puncticulata and G. inflata which indicate that this interval is early late Pliocene. The evolutionary transition between these two species has been shown to occur in the North Atlantic during that time, within nannofossil Zone NN 16 (Poore and Berggren, 1974, 1975). Other common taxa include Globorotalia crassaformis, Globigerinoides sacculifer, and Globigerina bulloides. Rare taxa include Neogloboquadrina pachyderma (dextral), N. atlantica (sinistral), and Globigerinoides ruber.

Core 416A-1 contains an extremely condensed lowerPliocene to lower-Miocene series. The early-Pliocene age of the upper part of the core $(23-25 \mathrm{~cm})$ is shown by the association of Globorotalia margaritae (common occurrence), Sphaeroidinellopsis subdehiscens, S. seminulina (both rare), and Globorotalia plesiotumida (rare). Among other taxa, Globigerinoides obliquus is common, and the following are rare: Globoquadrina altispira, Globigerina nepenthes, G. apertura, Globorotalia menardii group, Neogloboquadrina pachyderma (dextral and sinistral), and N. atlantica (sinistral). In the interval 85 to $87 \mathrm{~cm}, G$. margaritae is absent, and Sphaeroidinellopsis spp. and $G$. plesiotumida become more abundant. Despite the absence of the late-Miocene guide Globoquadrina dehiscens (possibly absent because of paleoclimatic control), this interval is attributed to the late Miocene, Zone N.17 - an age assignment in agreement with the nannofossil zone NN 11 for this part of the core.

The assemblage from the interval 139 to $140 \mathrm{~cm}$ is dominated by globoquadrinids ( $G$. altispira and $G$. dehiscens) and Globigerinoides sacculifer. Rare taxa include Orbulina, Sphaeroidinellopsis subdehiscens, and Globigerinoides subquadratus. The co-occurrence of the two latter species indicates an N.13 age (middle Miocene). In the core-catcher sample, Sphaeroidinellopsis subdehiscens and Orbulina are absent. The fauna includes rare Globorotalia peripheroronda and Globgerinatella insueta, which indicate an N.8 to N.7 age (early Miocene).

Core 416A-2, which contains Globigerinoides subquadratus, G. sacculifer, G. sicanus, Globoquadrina 
altispira, and Globorotalia siakensis, is assigned to the early-Miocene zonal interval N.6 to N.7. Samples examined from Cores 416A-4 and 416A-5 (selected in fine sediments which were expected to be more favorable for planktonic fauna) yielded an extremely poor planktonic fauna which could not be dated.

\section{Benthic Foraminifers}

Moderately abundant and well-preserved benthic foraminifers were recovered from graded basal sands within the alternating sand and nannofossil-marl and chalk layers of Cores 416A-2 and 416A-3. These foraminifers record the down-slope displacement of continental-shelf and -slope species into lower-bathyal environments at 2500 to 3500 meters. The indigenous assemblage consists of species of Eggerella, Vulvulina, Martinottiella, Bolivinopsis, Uvigerina, Pullenia, Laticarinina, Melonis, Stilostomella, Cibicidoides, and Anomalinoides. The transported assemblage consists of occasional shelf species of genera such as Buliminella, Nonionella, Trifarina, and several miliolid genera, and the more common upper-bathyal (500-1500 m) species of Uvigerina, Cassidulinoides, Bulimina, Bolivina, Globobulimina, and Plectofrondicularia, among others. In the overlying radiolarian- and diatom-rich marls, benthic foraminifers are rare, often poorly preserved, and wellsorted, most specimens ranging between 63 and $149 \mu \mathrm{m}$. The character of the foraminifer fauna and its relationship to the lithologic units suggest that these sediments represent deposition on a distal continental rise or fan.

\section{Mesozoic \\ Abundance and Preservation}

Foraminifers in Sample 416A-5, CC consist of extremely rare, poorly preserved Albian to Cenomanian planktonic foraminifers. Other biogenic constituents include rare benthic foraminifers, pyritized radiolarians, and fish debris, in this interval of severe carbonate dissolution. Rare fragments of hedbergellids in Core 416A-6 place this core in the Aptian to Albian interval. No planktonic foraminifers were found below Core 416A-6; consequently, subsequent ages are based upon rare benthic species that generally are limited to the coarse basal sands of gravity-flow sedimentary sources. Preservation remains poor, because of dissolution and recrystallization, and occurrences are sporadic.

The Hauterivian extends from Cores 416A-7 through 13, with questionable Barremian in Cores $416 \mathrm{~A}-7$ to 8 , based on the distribution of species of Gavelinella, Lenticulina, Frondicularia, and Vaginulinopsis. Foraminifers within this and the underlying interval become somewhat more abundant, but occurrences remain sporadic, and preservation generally is poor. Cores $416 \mathrm{~A}$ 14 through 416A-48 are Valanginian, with Lenticulina busnordoi and other species of Lenticulina, Epistomina, Dorothia, Astacolus, and Trocholina, among others.

Following Core 416A-48 and continuing to the bottom of the hole (Core 416A-57), the abundance of foraminifers again decreases, and samples are either barren or contain poorly preserved specimens. Foraminifers in
Cores $416 \mathrm{~A}-49$ and 50 suggest a Berriasian age, with long-ranging Jurassic species and the first appearance of Neocomian forms. Cores 51 through 57 are Late Jurassic (Kimmeridgian to Tithonian), with species of Epistomina, Trocholina, Patellina, and Trochammina.

\section{Paleoecology}

Two foraminifer assemblages are recognized within the gravity-flow sequences characteristic of the Neocomian and Jurassic sections at Site 416. The dominant assemblage is composed predominantly of size-sorted, transported, neritic species, which occur with echinoid spines, large fragments of bivalves, Inoceramus prisms, and ooids. The second assemblage consists predominantly of rare agglutinated species that are present in both the graded sand layers and the marly claystones and siltstones. This assemblage consists of species of Hyperammina, Glomospira, Reophax, Ammobaculites. Haplophragmium, and others, and is regarded as the indigenous deep-water assemblage. Water depths in excess of 2000 meters are suggested for this assemblage, with a depositional environment beneath the CCD.

\section{Radiolarians}

\section{Cenozoic}

Cores 416-1 and 416-2 contain extremely rare radiolarians and fragments of radiolarians. No age could be determined.

In Core 416A-1, radiolarians are rare and moderately well preserved. The species present, Cyrtocapsella tetrapera, C. cornuta, Stichocorys delmontensis, and Calocycletta virginis, are typical of the middle to lower Miocene, but are not confined to one zone.

In Core 416A-1, the radiolarian assemblages are moderately well preserved and appear to be at the boundary between the Calocycletta costata Zone and the Stichocorys wolfii Zone. The events which mark this boundary are the first occurrence of $C$. costata and the last occurrence of Lychnocanoma elongata; both species are found in the core catcher. On the other hand, L. elongata occurs in 416A-2, but does not occur in three samples from 416A-2-1, while $C$. costata is present in 416A-2-1, but not in 416A-2-3. Other species found in 416A-2 are Cannartus mammifer, C. violina, Liriospyris stauropora, Cyrtocapsella cornuta, C. tetrapera, Lithopera renzae, Stichocorys delmontensis, S. wolffii, Carpocanopsis bramlettei, C. cingulata, and Calocycletta virginis. Also found in 416A-2-1 and 416A-2, CC were reworked radiolarians from the Oligocene and lowest Miocene: Theocyrtis annosa, Artophormis gracilis, Lithocyclia aristotelis, and Theocorys spongoconum.

Core 416A-3 contains rare radiolarians and fragments diluted by common sponge spicules and diatoms. The ranges of most of the species present are very long, and their top and bottom occurrences are not known. An indication of mixing is given by $S$. delmontensis, which has a morphotypic bottom in the Miocene, and occurs here with Dorcadospyris ateuchus and Cyclampterium pegetrum, whose ranges are within the Oligo- 
cene. In the sandy layer at $416 \mathrm{~A}-3-3,126-127 \mathrm{~cm}$, there are even some Cretaceous species: Dictyomitra sp. and Artostrobium urna (Coniacian through Maestrichtian); the latter species gives us our sole indication of the presence of post-Cenomanian Cretaceous sediments in the area.

Samples examined from Cores $416 \mathrm{~A}-4$ and $416 \mathrm{~A}-5$ were barren of radiolarians.

\section{Mesozoic}

There were no radiolarians in any samples examined from Cores 416A-6 through 416A-57.

\section{Calpionellids}

Calpionellids are common in the turbidites of the Valanginian to Tithonian section below about 1328 meters (Cores $416 \mathrm{~A}-25$ to 57 ). A few isolated, probably reworked specimens were found in the Hauterivian (Cores 416A-8 and 9). Calpionellids are abundant in some carbonate layers. The facies with which they are associated, however, do not compare with the classic calpionellid limestone of the Mesozoic Tethyan realm, which is mainly pelagic; at Site 416 , all calcareous material is redeposited. Calpionellids here occur either (1) in clasts of micritic limestones incorporated in calcareous layers near the base of graded beds, together with other clasts of different nature (such as ooids, peloids, aptychi), or (2) isolated in more or less hemipelagic facies within mudstones and siltstones, in which case they are in graded beds, well sorted, and concentrated within laminae with other elements of their size class.

It thus appears that during the Tithonian and Early Cretaceous, calpionellid lime muds occurred higher on the eastern slope of the Agadir Basin. Although resedimentation of calpionellids into the basin at Site 416 is evident, the process was probably more or less penecontemporaneous with original deposition, as suggested by the normal, sequential order of first appearances of various fossils. On the other hand, as for other fossil groups at Site 416, "artificial" extension of the normal highest occurrences by reworking is common. Thus, only first occurrences can be used reliably for biostratigraphy. With this caveat in mind, the lowest occurrence of Remaniella cadischiana in Core 416A-52-3 is the first Berriasian guide, and the lowest occurrence of Lorenziella hungarica in Core 416A-48 is the first Valanginian guide.

\section{SEDIMENTATION RATES}

Because the upper sediment section was sampled only sparsely at Site 416 , core and log data both from this site and from Site 370 , approximately 1.2 miles to the east, are used to produce the most plausible rate-of-accumulation curve. Except for Cores 370-2 and 370-3, the coring technique employed in the upper, sparsely cored section of Site 370 differed from that used at Site 416. At Site 370 , pump pressure was reduced to core the top of the washed interval, in the hope that the core barrel would be filled before the washing operation, so as to prevent inadvertent sampling of sediment from other intervals. At Site 416, and for Cores 370-2 and 370-3, on the contrary, the interval was washed at full pump pressure, with the empty core barrel in place down to the last 9.5-meter section, where pump pressures were reduced for coring, which made it possible that firm sediments from above the nominally cored interval might enter the barrel.

While a comparison of the results obtained at the two sites should provide the most reasonable estimate of the rate of accumulation in the uppermost 430 meters, data are much too sparse to permit definite determination. Below that level, coring was closely spaced at Site 370 , so that by comparison Site 416 samples can be traced back to their appropriate original location. Coring was continuous at Site 416 below the total depth of Site 370 (1176.5 m).

In this report, data from Site 370 are reviewed first, to determine the rate of accumulation of the uppermost 1180 meters of sediment; then results from the upper part of the sedimentary column sampled at Site 416 are compared with these data. Finally, rates of accumulation are estimated below 1180 meters solely from Site 416 results.

\section{Review of Site 370 Rates of Accumulation}

Paleontological studies published in the DSDP Initial Reports, Volume 41 (Lancelot, Seibold, et al., 1978), have been used to arrive at revised rates of accumulation for Site 370 (Figures 47 and 48). The sedimentation-rate curve approximately parallels that constructed by Pflaumann (in Lancelot and Seibold, 1978), with minor modifications for the post-Hauterivian interval and significant ones for the base of the section.

\section{Cores 370-1 Through 370-5}

(Neogene and Uppermost Oligocene)

The discrepancy between foraminifer and nannofossil data, which indicate Pleistocene and late-Pliocene ages, respectively, for Core 370-1, probably results from mixing of sediments of both ages by coring disturbance, as evidenced by results from Site 416 . At Site 416 , a distinct lithologic change occurs at only $45 \mathrm{~cm}$ subbottom, marking an unconformity between the late Pleistocene and late Pliocene. Excellent agreement between foraminifer and nannofossil data indicate a hiatus of about $1 \mathrm{~m} . \mathrm{y}$. Sediments just above the unconformity are not older than 0.5 m.y., and those just below it are about 2.5 to $3.0 \mathrm{~m}$.y. old. It thus appears that only a veneer of Quaternary sediments overlies late-Pliocene sediments. The Pleistocene surficial veneer is too thin to be shown correctly on the figures.

As a result of the coring techniques, it is possible that Core 370-2 represents an interval anywhere between 10 meters and 112.5 meters sub-bottom, and the same caution should be applied to Core 370-3. The positions of Cores 370-4 and 370-5 are, however, more firmly established. An average rate of accumulation of about 10 $\mathrm{m} / \mathrm{m} . \mathrm{y}$. is obtained for the Pliocene to middle Miocene between cores 1 and 2, taking the age assignment of the sediments recovered in Core 2 (approximately $14 \mathrm{~m} . \mathrm{y}$.) as a minimum age for the nominal level of the Core 2 bottom. Between the latter level and the bottom of Core 


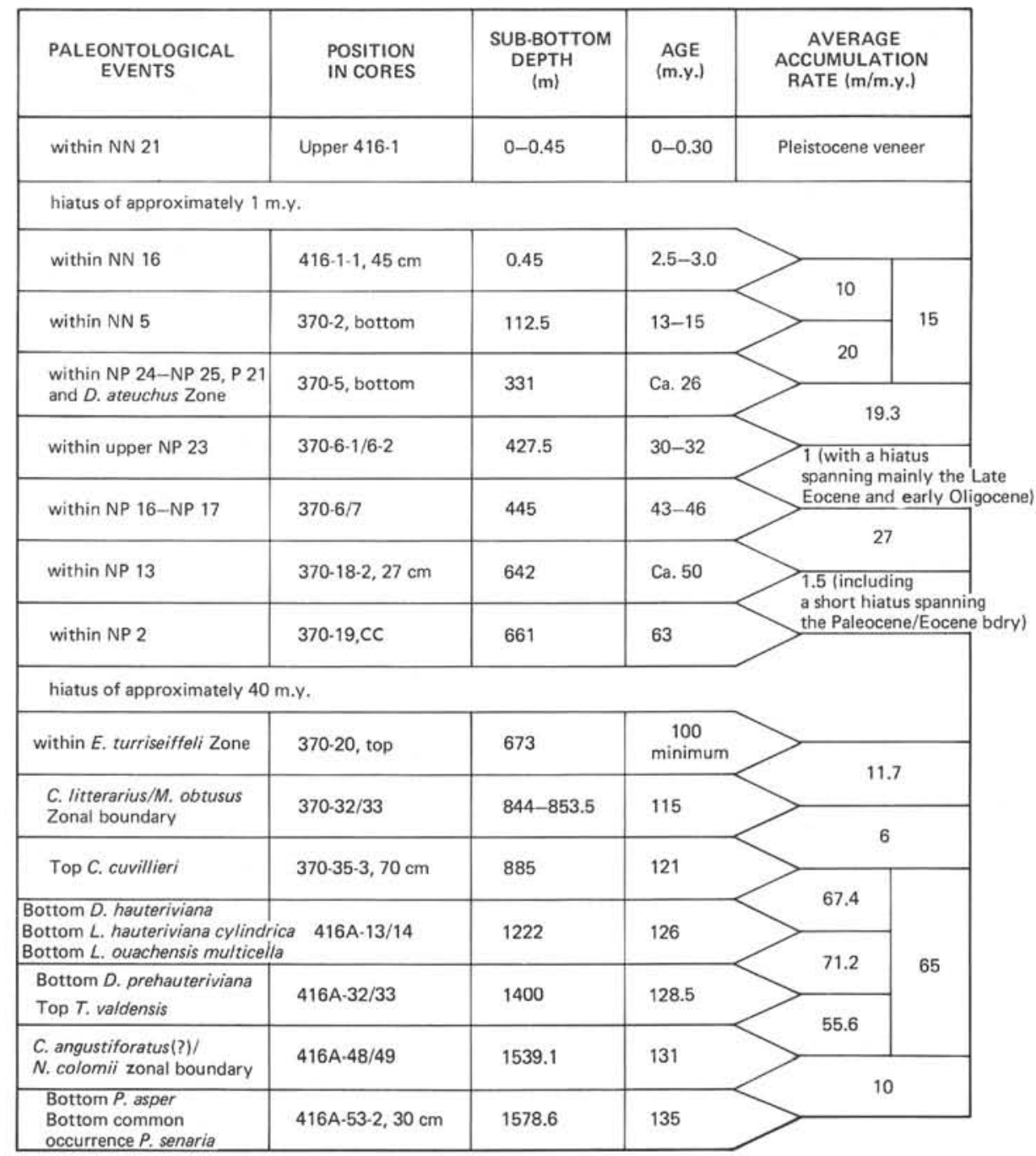

Figure 47. Average sediment accumulation rate at Sites 416 and 370.

5 , an average rate of accumulation of about $20 \mathrm{~m} / \mathrm{m} . \mathrm{y}$. is obtained for the lower Miocene and uppermost Oligocene. This value agrees with nannofossil and radiolarian data from Core 4. Nannofossil data from Core 3, however, suggest that this core represent sediments stratigraphically higher than its nominal interval. Biostratigraphic mixing in this core is indicated by the age disagreement among the various fossil groups (middle to early Miocene).

Based on the accumulation-rate curve, the Pliocene/Miocene, upper/middle Miocene, middle/lower Miocene, and Miocene/Oligocene boundaries are placed at 35, 78, 150, and 285 meters, respectively (Figures 6 and 46).

\section{Cores 370-6 Through 370-19 (Paleogene)}

Beginning with Core $370-6$, coring was almost continuous, and the problem of sample location nearly disappears. We are thus provided with a reliable basis for comparison with results from Site 416. The upper part of Core 370-6 (Section 1) is dated as uppermost lower Oligocene, whereas the lower part (Section 2 and core catcher) contains mixed fossil assemblages ranging in age from middle Eocene to Oligocene. Core 370-7 is upper middle Eocene. This implies (1) a high average rate of accumulation (about $20 \mathrm{~m} / \mathrm{m}$.y.) for the upper Oligocene, and (2) a very condensed section ( 17.5 meters for $13.5 \mathrm{~m} / \mathrm{m} . \mathrm{y}$.) or a hiatus between the middle Eocene and the uppermost Oligocene.

The results obtained at Site 415 suggest a hiatus between Eocene and Miocene strata, and data from Site 370 confirm this interpretation. They also suggest that the hiatus omits mainly the late Eocene and early Oligocene.

Late early to middle Eocene times were characterized by a relatively high average rate of accumulation (about $27 \mathrm{~m} / \mathrm{m} . \mathrm{y}$.). A short hiatus in Core 370-18 spans the Eocene/Paleocene boundary, and a condensed Paleocene section occurs in Core 370-19. The average rate of accumulation for the entire Paleocene is on the order of 1 $\mathrm{m} / \mathrm{m} . \mathrm{y}$. This highly condensed Paleocene series may mark the last phase of the time associated with the underlying substantial hiatus (about 40 m.y.) that separates the earliest Paleogene from the Cenomanian. 

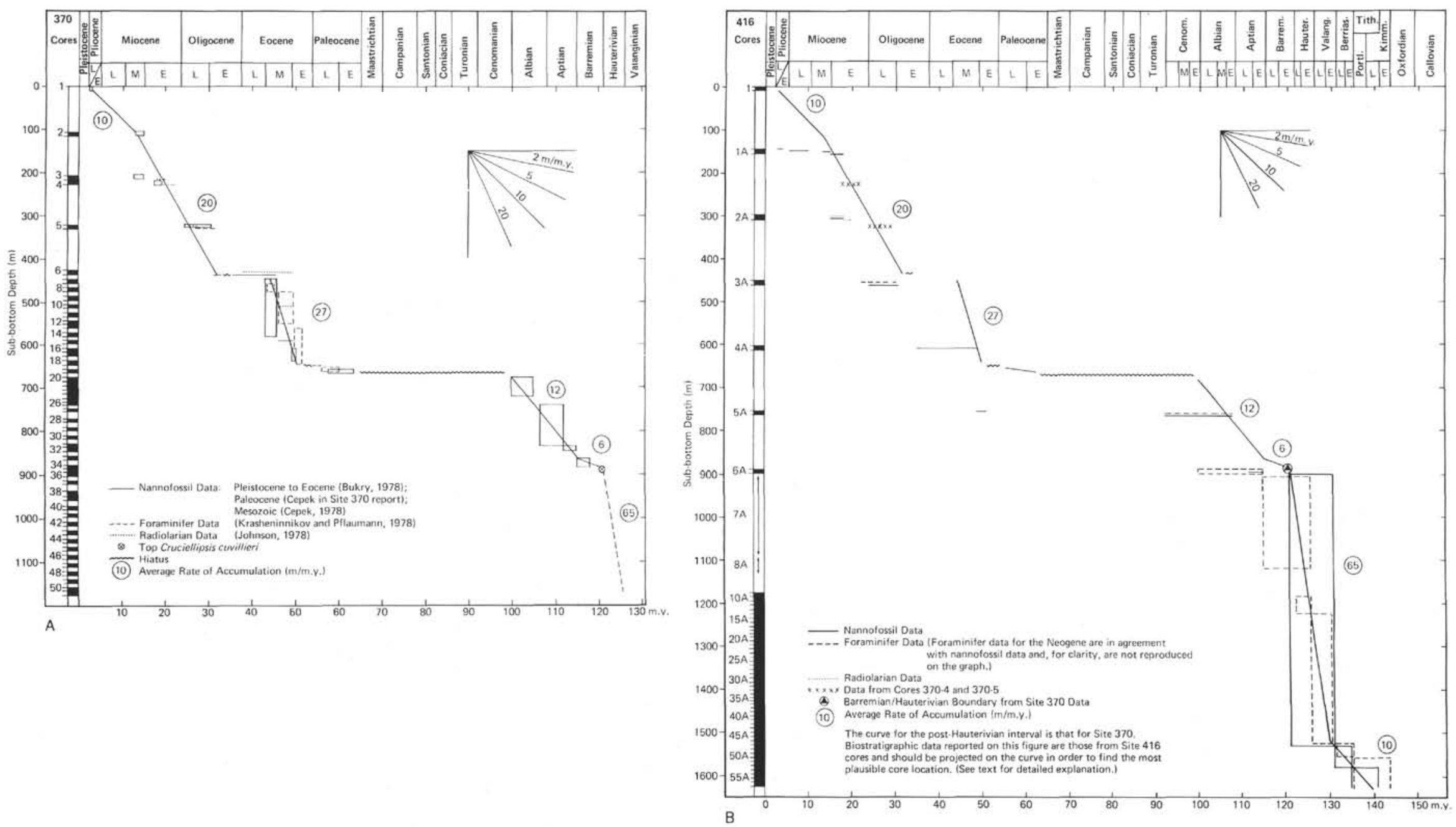

Figure 48. Sedimentation rate curves for (A) Site 370 and (B) Site 416. 
Cores 370-20 Through 370-51 (Cretaceous)

Cores 370-20 to 24 are assigned to the Eiffellithus turriseiffeli nannofossil zone. A late-Albian age is therefore attributed to the top of Core 370-20, and minimum age of $100 \mathrm{~m} . \mathrm{y}$. (Cenomanian/Albian boundary) is assigned to that level. The Barremian/Hauterivian boundary, marked by the last occurrence of Cruciellipsis cuvillieri, is located within the upper part of Core $370-25$, at approximately 885 meters. Thus, it appears that sediments accumulated at an average rate of 12 $\mathrm{m} / \mathrm{m} . \mathrm{y}$. during Albian-Aptian time, and at a reduced rate of about $6 \mathrm{~m} / \mathrm{m} . \mathrm{y}$. during the Barremian.

The intervals between the lower part of Core 370-38 and 370-50-1 and between 370-50-2 and the bottom of Core 370-51 (bottom of the hole) tentatively had been assigned by Cepek (1978) to the Calcicalathina oblongata Zone (late Valanginian to early Hauterivian) and to the Cretarhabdus angustiforatus ( $=C$. crenulatus) Zone (early Valanginian), respectively, on the basis of the lowest occurrence of Parhabdolithus infinitus in the upper part of Core 370-38 and of C. oblongata in Core 370-50, Section 1. It now appears, however, that these two levels do coincide with the first appearances of these two species, whose occurrences are rare and sporadic. At Site 416A, P. infinitus ranges as low as 1250 meters, and $C$. oblongata as low as 1440 meters.

A comparison between Sites 416 and 370 suggests that drilling at Site 370 terminated at 1176.5 meters in the early Hauterivian. The accumulation rate for the Hauterivian section cannot be estimated at Site 370, but it is probably similar to that at Site 416 , which has the very high value of $65 \mathrm{~m} / \mathrm{m}$.y. Thus, an abrupt change in the sedimentation regime appears to have taken place about 121 m.y. ago (Hauterivian/Barremian boundary).

\section{Rates of Accumulation At Site 416}

Average accumulation rates for Site 416 are plotted on Figures 47 and 48. As discussed earlier, a veneer of Pleistocene sediments not older than 0.5 m.y. unconformably overlies late-Pliocene sediments 2.5 to $3 \mathrm{~m}$.y. old. For clarity, the Pleistocene interval (upper $45 \mathrm{~cm}$ of Core 416-1) is not shown.

The section was very sparsely cored down to a subbottom depth of 1176 meters, below which coring was continuous. As described earlier, the coring technique used in the upper part of the section may have produced cores with an artificial "condensing" of the stratigraphic levels penetrated while washing the drill string down with the empty core barrel in place, before reducing pump pressure for actual coring.

A good example of such an artificially "condensed" section is observed in Core 416A-1, where strata of the Pliocene and late, middle, and early Miocene were recovered. The nominal interval indicated for Core 416A-1 is 146 to 155 meters (Table 1). Core $370-2$, which is at least 43 meters higher (the nominal interval of this core is $103-112.5 \mathrm{~m}$ ), contains sediments of the lower middle Miocene, indicating a minimum age for the 112.5-meter level. This clearly indicates that sediments of equivalent age in Core 416A-1 (Section 1 below 90 $\mathrm{cm}$, and Section 2) cannot truly represent the strata from the nominal interval indicated for Core 416A-1, and that they come from a level higher in the section-at least as high as $112.5 \mathrm{~cm}$.

Core 370-3, some 50 meters below Core 416A-1, contains nannofossil assemblages of the same age as those of Core 370-2 (early middle Miocene), and younger than those from the core catcher of Core 416A-1. It is thus probable that "condensing" and inadvertent sampling also occurred between Cores 370-2 and 370-3, an inference supported by the biostratigraphic mixing noted in the latter core.

Core 416A-2 (298-307.5 m) is assigned an early-Miocene age similar to that of Core 370-4, higher in the section. Again, this is obviously caused by "condensing," or spot sampling, during the drilling of the interval between Cores 416A-1 and 2. This is confirmed by the late-Oligocene age of Core 370-5, only 20 meters below Core 416A-2. Because the positions of Cores 370-4 and 5 are more firmly established than either those of Cores $370-2$ and 3 or of cores from Site 416, the data obtained at Site 370 from Core 4 and below are used here for estimating the most plausible accumulation rates.

Core 416A-3 (450-459.5 m) yielded late-Oligocene fossils equivalent in age to those of Core 370-5, 30 meters above Core 416A-3. Sediments from the latter core therefore must come from higher levels in the hole. Misplacement probably here is aggravated by inadvertent sampling from the "condensed" section, or near the hiatus, which is inferred from Site 370 results to be at about 430 to 445 meters.

Biostratigraphic data from Core 416A-4 are very poor. This core contains nannofossils ranging in age from middle to upper Eocene, spanning an interval equivalent to that sampled by Cores $370-7$ through 370-15. Nannofossils in Core 416A-5 show that only the core-catcher sample (Albian) appears to have been recovered from a level close to the actual level reached by the drill bit at the end of the coring, whereas the upper part of the core (Section 1, early Eocene) must be a sample from considerably higher levels in the hole. Core 416A-6 also was assigned an age (Aptian) younger than the corresponding level from Site 370 (Barremian); again, this probably is caused by spot sampling and "condensing" of lithologies during drilling.

The Hauterivian/Barremian boundary was not observed in cores at Hole 416A and has been placed at 885 meters on the basis of results from Site 370 . Biostratigraphic data for Cores 416A-7 and 8 , recovered while drilling below this level, indicate a late-Hauterivian age (Lithraphidites bollii Zone, within the range of $C$. cuvillieri), which is in agreement with the location of the Barremian/Hauterivian boundary at 885 meters.

The Valanginian/Hauterivian boundary, recognized at 1222 meters on the basis of foraminifers (between Cores 416A-13 and 14), gives a datum point of 126 m.y., and the Valanginian/Berriasian boundary at 1539.1 meters (between Cores 416A-48 and 49), identified on the basis of nannofossils and foraminifers, gives a datum point of $131 \mathrm{~m} . \mathrm{y}$. Based on these data, a high 
average rate of accumulation of $65 \mathrm{~m} / \mathrm{m}$.y. can be inferred for the turbidites of the entire HauterivianValanginian interval.

Although the lower/upper Valanginian boundary is not clearly defined, there is some foraminifer evidence (Dorothia prehauteriviana, an upper-Valanginian index, in and above Core 416A-32, and Trocholina valdensis, a lower-Valanginian index, below Core 416A-32) that this boundary occurs near Core 416A-32. The highest occurrence of the nannofossil Rucinolithus wisei (a middle-Valanginian event) in Core 416A-31 supports this assumption. It thus follows that there was a lower average rate of accumulation during the early Valanginian $(56 \mathrm{~m} / \mathrm{m} . \mathrm{y}$.) than during the late Valanginian (71 $\mathrm{m} / \mathrm{m} . \mathrm{y}$.)

The Jurassic/Cretaceous boundary is placed at 1578.6 meters (within Core 416A-53, Section 2) on the basis of nannofossils, providing a datum point of 135 m.y. and an average accumulation rate of $10 \mathrm{~m} / \mathrm{m} . \mathrm{y}$. for the entire Berriasian interval.

The marked decrease in average accumulation rate for the lower part of the section is in agreement with foraminifer data, which indicate that transported elements decrease in abundance below Core 416A-40, while indigenous deep-water species become the dominant faunal element. On the other hand, the average thickness of turbidite beds is at a minimum in the interval from Cores 33 to 38 , in the lower part of the Valanginian, and thick beds rich in redeposited shallow-water calcareous debris are common below Core 38 .

Because the majority of the sediments resulted from distal resedimentation processes, the highest occurrence of index species in the various fossil groups can be misleading. One must therefore rely on first occurrences to identify biostratigraphic boundaries. In addition, the absence of index species may result from the poor preservation which was observed in all the calcareous-microfossil groups. As a result, the possibility that the biostratigraphic boundaries drawn here are stratigraphically too high should not be excluded.

Assuming that Tithonian sediments accumulated at the same rate as those of the overlying Berriasian, the sediments at the base of the hole would be early Tithonian, approximately 139.5 m.y. old.

\section{COMPARISON OF SEISMIC-REFLECTION PRO- FILES WITH DRILLING AND LOGGING RESULTS}

Seismic-reflection-profiler coverage near Site 416 (Figure 3) includes two multichannel lines (GSI's AIP and Meteor 3902 lines) and one single-channel line (Lamont's Vema 3013) that provide excellent records of the acoustic stratigraphy all the way to basement, which lies some 2.6 seconds of reflection time beneath the sea floor. The GSI line was used in site selection by the JOIDES panels and was available for use aboard the ship, but the company would not release the records for publication. Average stacking velocities used in the common-depth-point processing of the multifold lines are known from the Meteor line (see underway-geophysics chapter for a reproduction of this record) and pro- vide a means for estimating the depths to the various reflectors at Site 416. The curve of depth versus reflection time for the Meteor multifold line is shown in Figure 49, and the estimated depths to various reflectors at Site 416 are shown in Table 9, along with estimates based on the results of drilling and logging at Sites 370 and 416 .

Three key reflectors (brown, red, and blue) can be traced with some confidence along the Meteor line from near Site 415 to near Sites 416 and 370; these are shown in the simplified line drawing of Figure 2. This original profile appears in the chapter on underway geophysics in this volume. Several major features stand out on the profile and help in fixing the depths of reflectors at the two sites. The seismic section along the Meteor line has several distinctive acoustic units that tell us something of the geologic history of the region.

The somewhat irregular acoustic basement is overlain by sediment of highly variable thickness that tends to fill in the low places and pinch out against the highs. Near Site 416 (Figure 50), these sediments may be as much as $1 \mathrm{~km}$ thick. This irregularly distributed and poorly stratified sequence is overlain by a remarkably parallel sequence of reflectors that thins southward from about

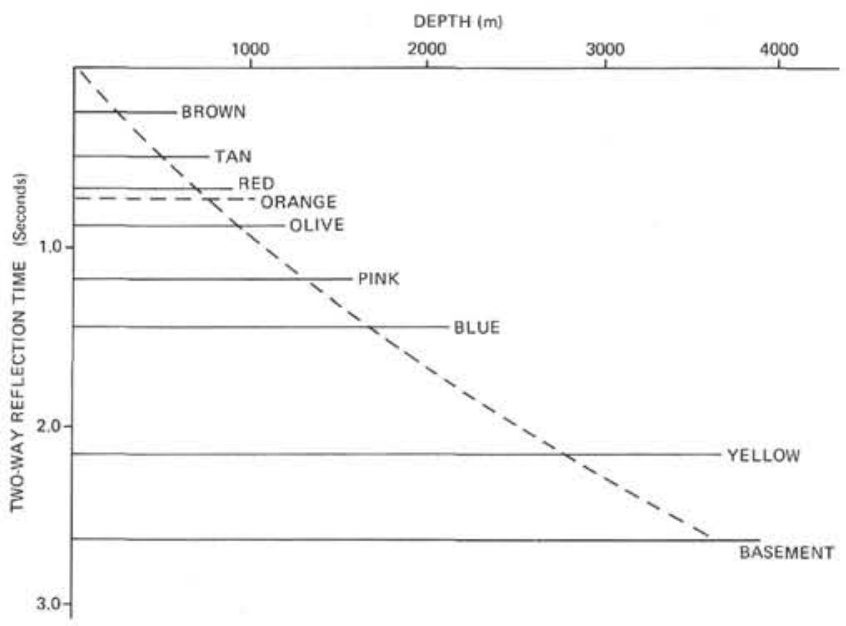

Figure 49. Depth versus reflection time for Meteor 3902. Multifold seismic line (courtesy of K. Hinz. Bundesanstalt für Geowissenschaften und Rohstoffe).

TABLE 9

Estimated Depths of Various Reflectors at Site $\mathbf{4 1 6}$

\begin{tabular}{lcccccc}
\hline & $\begin{array}{c}\text { GSI } \\
\text { Two-Way } \\
\text { Reflection } \\
\text { Time } \\
\text { (seconds) }\end{array}$ & $\begin{array}{c}\text { Estimated } \\
\text { Depth } \\
\text { (Meteor) } \\
(\mathrm{m})\end{array}$ & $\begin{array}{c}\text { Esti- } \\
\text { mated } \\
\text { Depth } \\
(\mathrm{GSI}) \\
(\mathrm{m})\end{array}$ & $\begin{array}{c}\text { Estimated } \\
\text { Depth } \\
\text { from } \\
\text { Drilling } \\
\text { and } \\
\text { Logging } \\
(\mathrm{m})\end{array}$ & $\begin{array}{c}\text { Interval } \\
\text { Velocity } \\
\text { (from next } \\
\text { reflector } \\
\text { above) } \\
(\mathrm{km} / \mathrm{s})\end{array}$ & $\begin{array}{c}\text { Interval } \\
\text { Velocity } \\
\text { (from } \\
\text { sea floor) } \\
(\mathrm{km} / \mathrm{s})\end{array}$ \\
\hline Sea floor & 0 & 0 & 0 & 0 & - & - \\
Brown & 0.225 & 214 & 225 & $\sim 200$ & $\sim 1.78$ & $\sim 1.78$ \\
Tan & 0.485 & 480 & 500 & 457 & 1.98 & 1.90 \\
Red & 0.660 & 670 & 700 & 642 & 2.11 & 1.95 \\
Olive & 0.870 & 920 & 970 & 834 & 1.83 & 1.92 \\
Blue & 1.430 & 1660 & 1750 & $>1624$ & $>2.82$ & $>2.27$ \\
Yellow (?) & 2.155 & 2780 & 3011 & - & - & - \\
Basement & 2.625 & 3580 & 3867 & - & - & - \\
\hline & & & & & & - \\
\hline
\end{tabular}




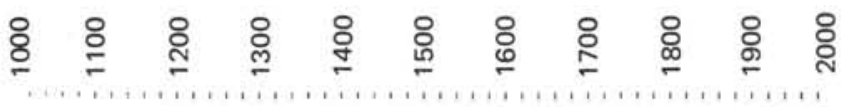
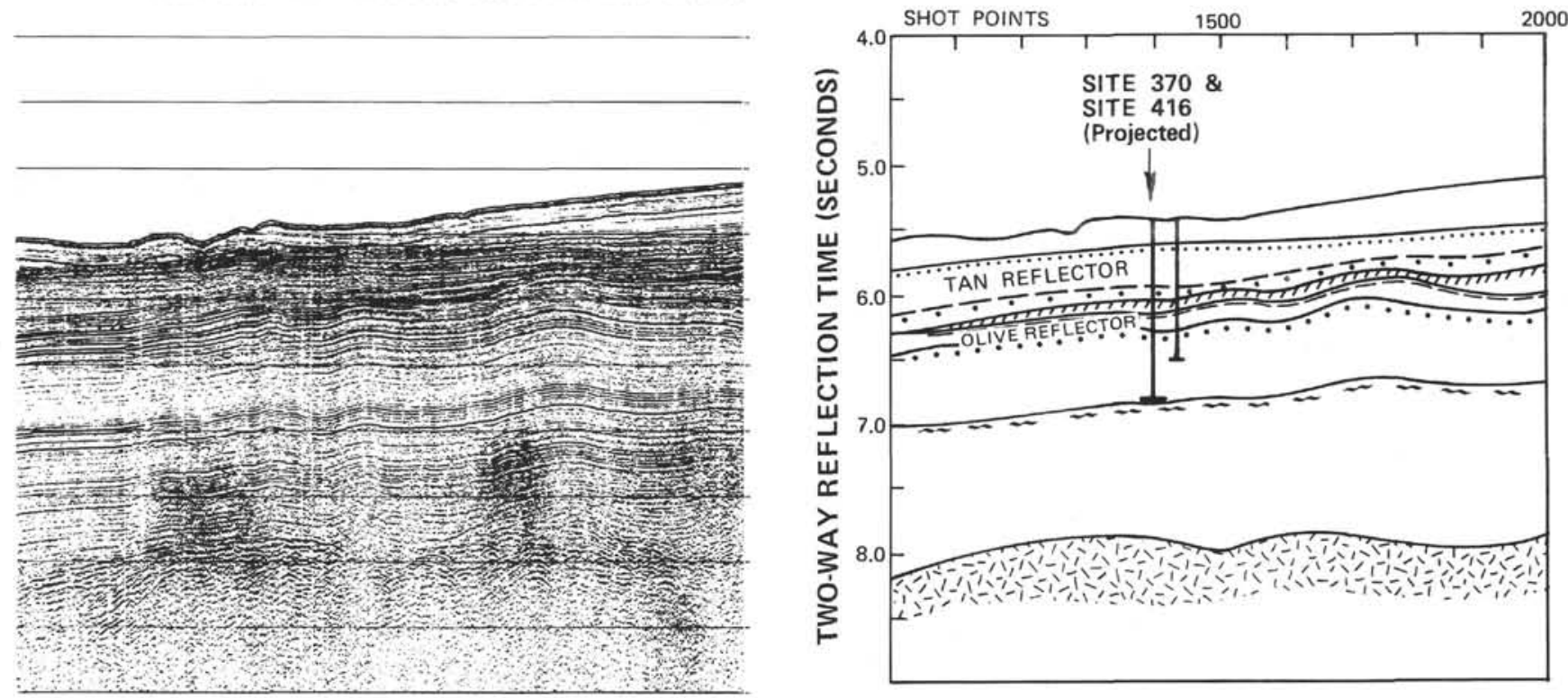

Figure 50. Meteor 3902 multichannel profile recorded in the vicinity of Site 416. (See location in Figure 3.)

1.0 second near Site 416 to about 0.5 second near Site 415. Near Site 415, the contact between this parallel series and the rocks below is drawn as the yellow reflector, and here the contact is clearly angular; below this contact, the pre-yellow sediments appear to be tilted and faulted. On the other hand, near Site 416 the angular relationships are not as clearly shown, and the yellow reflector cannot be identified with certainty. The oldest sediments appear to pinch out gradually against acoustic basement southward from Site 416 , but there is a rather abrupt rise in the basement only about $30 \mathrm{~km}$ north of Site 415, where multiples obscure the Meteor profile. There may be an important fault or fracture zone in the basement rocks here. The pre-yellow sediments are of unknown age and lithology, but their geometry plausibly identifies them with the rifting or earliest drifting stage of opening of the Atlantic.

The acoustic unit between the yellow and blue reflectors is very distinctive in having a large number of closely spaced, parallel, and very extensive reflectors. Drilling at Site 416 probably did not reach this unit. The blue reflector at the top of the unit is one of the strongest reflectors in the entire column, and it is possible that the increase in hard turbidite limestone layers in the lowest cores at Site $\mathbf{4 1 6}$ may signal that we were approaching the level of the reflector at the final depth of 1624 meters, in strata of Tithonian age. The close parallelism of the reflectors within the unit between the blue and yellow reflectors further suggests that we may be dealing with turbidites, and the high impedance contrast suggests that these could be limestone turbidites with high density and high sound velocity alternating with shales of much lower density and velocity.
The yellow-to-blue unit drapes over basement highs, at least in the region about halfway between Sites 415 and 416 along the Meteor profile (Figure 2), and the question arises: are these tectonic folds, or is this simply sedimentary draping, so common in pelagic sequences? If many of the reflectors in this unit are turbidites, then the folds must be tectonic, because it is unlikely that turbidity currents would have deposited such a uniformly parallel sequence over hill and dale alike. Ponding would be expected. Along the northern parts of the $\mathrm{Me}$ teor profile, the folding appears to include the basement. We should admit at least two possibilities: (1) there is an unconformity at the yellow reflector, and folding has warped the basement, the unconformity, and the overlying sediments (up to the red reflector); or (2) there is a structural decollement at the yellow reflector, and the folding is mainly confined to the overlying sediments. A decollement at the top of an early-rifting evaporite sequence is plausible, and even common elsewhere. The first alternative implies penetrative tectonism involving the basement; the second might require only gravity tectonics. Data in the public domain do not permit a clear choice between the alternatives.

A curve showing depth versus reflection time (Figure 49), derived from multichannel seismic data, predicts a depth of about 1660 meters for the blue reflector at Site 416; the drilling data do not help much in pinning this down more precisely. The highest level at which hard limestone occurs in any abundance is in Cores 416A-51 and 52, at 1560 to 1575 meters, but the major acousticimpedance contrast should be deeper than 1624 meters, judging from the lithology of the last cores. In any event, the blue reflector probably lies within the Upper 
Jurassic, near the top, or perhaps as low as the lower Kimmeridgian or even the Oxfordian. Biostratigraphic data suggest that the total depth of 1624 meters may be close to the base of the Tithonian.

At Site 416, the next major reflector above the blue is the olive (Figures 2 and 50), at about 0.87 second below the sea floor. Coring at Site 370 shows a change at about 834 meters from mainly claystone above to claystone plus siltstone, sandstone, and conglomerate below, and the drilling rate curves for both Sites 370 and 416 show a change from faster drilling above to slower drilling below (Figure 6). This is close to the Aptian/Barremian boundary, and at the highest occurrence of coarse clastics, but about 46 meters above the top of the main turbidite section that continues to the total depth reached at the site. The sedimentation rate curve (Figure 48) does not show any break at this point, in spite of the change of lithology; instead, the break comes at about 880 meters, where the top of the regularly bedded turbidite succession begins. The interval velocity for the olive-to-blue interval is $>2.82 \mathrm{~km} / \mathrm{s}$ if 834 meters is used as the top; it is $>2.66 \mathrm{~km} / \mathrm{s}$ if 880 meters is used. Finally, it may or may not be seismically significant that 840 meters was about the depth at which the pipe became stuck during re-entries, and at which we finally were frustrated in our logging attempts. In Table 10, both possibilities are shown, with velocity calculations for each.

The olive-to-blue interval resembles the section beneath the blue reflector, except that not as many of the internal reflectors are as continuous as in the older unit. The cores show that the unit consists almost entirely of turbidites, which are very sandy at the top of the interval and more muddy below. Internal reflectors are more numerous in the upper part of the unit than in the lower, doubtless in response to the lithologic change from more sandy to more muddy.

Between the olive and red reflectors, the acoustic stratigraphy is complex. As the section is traced northward from near Site 415 (Figure 2), the interval thins, apparently for the most part by successive truncation of units beneath the red reflector, which therefore must lie very close to a major unconformity. The orange reflector virtually disappears as it is traced northward to Site 416 , there being only about 0.06 second between it and the red reflector, whereas at Site 415 there is about 0.6 second. No evidence was seen at Sites 370 or 416 of the scrambled Cenomanian stratigraphy, affected by gravity slide sheets, which characterizes the red-to-orange interval at Site 415. Perhaps the slides never reached Site 416; however, because no certain Cenomanian was cored at Sites 370 or 416 , the likelihood is that whatever Cenomanian was here was later eroded.

The red reflector is clearly and unambiguously shown in the several kinds of down-hole logs by a very abrupt change at 642 meters. Sonic velocity, gamma radiation, density, and resistivity drop in comparison to values for the unit next above. The reflector corresponds to the lithologic change between lower-Eocene coarse-grained clastic rocks and Paleocene fine-grained calcareous marlstone and claystone. Faunal evidence from Site 370 indicates a small hiatus at this level. The big hiatus between the Paleocene and the Middle Cretaceous lies about 20 meters below the red reflector, and in areas away from Site 416 it in fact may be the red reflector. The two levels would be separated by only about 0.02 second of reflection time on the seismic profiles-an interval probably too thin to discriminate consistently.

The topography of the red reflector does not parallel that of the underlying reflectors, and clearly unconformable relations are shown at many places along the Meteor profile (Figure 2).

The interval velocity between the red ( 642 meters) and olive reflectors is only $1.83 \mathrm{~km} / \mathrm{s}$ if 834 meters is taken as the olive reflector; it is $2.27 \mathrm{~km} / \mathrm{s}$ if 880 meters is chosen. The lower figure is substantially less than the interval velocity below the olive reflector, and much less than in the Eocene clastic rocks above the red reflector. The red-to-olive unit at Site $\mathbf{4 1 6}$ might therefore include a low-velocity zone, correlating mainly with middleCretaceous mudstones. The sonic-velocity log does indeed show very low velocities at the top of the unit, in the first 50 meters below the red reflector, but these probably are caused in part by the large-diameter hole.

The prominent reflector at 0.485 second on the seismic profiles near Site 416 (Figure 48) is shown boldly on the sonic and gamma-ray logs at 457 meters. This depth corresponds to the top of a relatively coarse-grained sandstones and conglomerates interbedded with marlstone with porcellanite nodules. The top of this formation lies close to the boundary between the middle and upper Eocene as determined from cores at Site 370, and is about 30 meters below the big hiatus between the upper Eocene or lower Oligocene and the lower Miocene. The interval velocity for the tan-to-red unit is 2.114 $\mathrm{km} / \mathrm{s}$.

The tan-to-red unit can be traced with confidence only about $50 \mathrm{~km}$ southward from Site 416 , and in that area it has the general physiography of a ponded-turbidite section; it may never have been deposited on the higher ground farther south.

Because coring was discontinuous in the upper parts of the section at both Sites 370 and 416 , the brown reflector, at 0.225 second below the sea floor, cannot certainly be recognized in the cores. The logs are not as much help as we had hoped: the sonic log shows a prominent change in velocity at 186 meters, and another at about 215 meters, at roughly the top and base of a transition from lower gamma values above to higher below. The interval velocity from sea level for a reflector at 186 meters is $1.65 \mathrm{~km} / \mathrm{s}$, which seems a little low, and for a reflector at 215 meters it is $1.91 \mathrm{~km} / \mathrm{s}$, which definitely seems too high, considering the kind of cored sediment. The lower value would also force a velocity of 2.08 $\mathrm{km} / \mathrm{s}$ in the brown-to-tan interval, which looks too high in view of the $2.114 \mathrm{~km} / \mathrm{s}$ velocity in the underlying tanto-red interval, and in view of the nature of the cores. The sonic log suggests a mean velocity of about 1.7 $\mathrm{km} / \mathrm{s}$. Thus, we have no real basis for identifying the level of the brown reflector; the logs and observed prop- 
TABLE 10

Hydrocarbon Monitoring in the Cenozoic of Hole 416A

\begin{tabular}{|c|c|c|c|c|c|c|}
\hline Core & $\begin{array}{l}\text { Interval } \\
\text { below } \\
\text { Sea Level } \\
\text { (m) }\end{array}$ & $\begin{array}{l}\text { Fluores- } \\
\text { cence }\end{array}$ & GQF & $\begin{array}{l}\mathrm{CH}_{4} \\
\text { (\%) }\end{array}$ & $\mathrm{C}_{1} / \mathrm{C}_{2^{+}}$ & Pyrolysis Data \\
\hline $416 \mathrm{~A}-1$ & $4349-4358.5$ & None & 0 & $<0.0005$ & - & $\begin{array}{l}\text { No generated hy- } \\
\text { drocarbons; very } \\
\text { immature; } 0.7 \\
\text { mg/g potential } \\
\text { hydrocarbons }\end{array}$ \\
\hline $416 \mathrm{~A}-2$ & $4501-4510.5$ & None & 0 & $<0.0005$ & - & As above \\
\hline $416 \mathrm{~A}-3$ & $4653-4662.5$ & None & 1 & $\begin{array}{c}0.8 \\
11.8^{*}\end{array}$ & $6330^{*}$ & As above \\
\hline $416 \mathrm{~A}-4$ & $4805-4814.5$ & None & - & - & - & $\begin{array}{l}\text { Very slight gener- } \\
\text { ated hydrocarbons; } \\
1.2 \mathrm{mg} / \mathrm{g} \text { potential } \\
\text { hydrocarbons; im- } \\
\text { mature sediments }\end{array}$ \\
\hline
\end{tabular}

"Sample taken after core lay one or more hours on the rack.

erties of the cores would place it somewhere around 200 meters, probably near the boundary between the middle and lower Miocene.

\section{SAFETY AND POLLUTION-PREVENTION PROGRAM}

\section{Cenozoic}

Two cores were taken in the pilot hole (Hole 416), with poor recovery. No gas samples were taken.

In Hole 416A, four cores were taken in the Cenozoic from 4349 to 4967.5 meters (158-766 m sub-bottom). The information derived from these cores appear in Table 10. In the Cenozoic, only minor amounts of methane and ethane were found. The pyrolysis data indicated that the sediments were generally immature, there were little or no generated hydrocarbons, and the potential for hydrocarbons was also small.

\section{Mesozoic}

Forty-eight cores were taken in the Cretaceous, from Core 416A-5 through Core 416A-52; the ages ranged from Cenomanian to Berriasian. A summary of the data appears in Table 11. In general, the Cretaceous sediments sampled from Hole $416 \mathrm{~A}$ were characterized by very small amounts of gas. From Core 416A-7 through Core 416A-51, methane was less than 1 per cent. From Core 416A-31, samples taken immediately after the core was brought on deck had methane concentrations too small to measure. Only after the core had remained 2 or more hours on the rack and then sampled was gas obtained in measurable quantities. The ratio $\mathrm{C}_{1} / \mathrm{C}_{2}+$ and the ratios of $C_{3}, C_{4}$, and $C_{5}$ are more typical of petroleum gases, but the extremely low measured volume of gas negated any cause for alarm about safety or pollution.

Pyrolysis data through Core 416A-51 indicated no generated hydrocarbons, only minor amounts of potential hydrocarbons, and probably type 3 kerogen. From approximately 1200 meters, the sediments become mature, but maximum maturity has not been achieved.

Five cores were taken in the Jurassic (416A-53 through 416A-57) from 5780 to 5827 meters. As in the Cretaceous, when cores were sampled immediately the methane quantity was too low to measure, and even after a delay of more than 2 hours only very small amounts of gas were recorded.

Pyrolysis data from 416A-52 and 416A-57 indicated very little generated hydrocarbons, very low potential for hydrocarbons, and the beginning stage of maturation.

\section{SUMMARY AND CONCLUSIONS \\ Introduction}

After abandoning Site 415 and moving toward the northern alternate site in the vicinity of Site 370 (Figure 1), we recognized that, within the time remaining to us, our chances to reach the deepest part of the sedimentary section were almost nil. Nevertheless, we still had every reason to believe that if we could equal the performance of the previous deep, multiple re-entry (Site 398), we probably could reach strata lying well below the blue reflector. The frustrations that accompanied our attempt at Site 415 were soon overcome, especially after we had set the cone and casing and made our first re-entry at Site 416 . At Site 370 , only $2 \mathrm{~km}$ away, coring had been almost continuous from 430 to 1176 meters; thus, both the lithology and the rates of penetration were already known with precision. Furthermore, there was no more question about safety or pollution-prevention problems in drilling this uppermost section, and only a few cores need be taken for technical reasons. The exciting scientific studies were then expected to begin in the new domain below the 1180-meter mark. Evidence from the Meteor 3902 multichannel and the Vema 30-13 singlechannel profiles showed that the blue reflector should lie at a sub-bottom depth of about 1650 meters, and a total penetration of more than 2000 meters was still expected.

The total depth of 1624 meters actually reached at the site of course fell far short of our hopes. The bad hole conditions that blocked progress and ultimately foiled our venture were probably caused by the caving of weak mudstone layers, especially where they overlie harder sandstone or siltstone intervals. It is risky to draw definite conclusions about the technical aspects of this attempt, but it appears that the major problems posed by drilling deep holes in the predominantly terrigenous or hemipelagic facies that characterize continental margins are the difficulty of removal of cuttings from the hole, the poor stability of the hole, and the low efficiency of the available drill bits.

In any case, a relatively complete section of the postLate Jurassic sediments has been sampled; it was very frustrating not to be able to reach Middle and Lower Jurassic strata, but much information has been gained from this site, contributing to our understanding of the evolution of this continental margin, and of the processes of sedimentation and diagenesis in this environment.

\section{Paleoenvironment}

The combination of results from Site 416 and Site 370 provides the basis for reconstruction of the environments in the Moroccan Basin since some time in the 
TABLE 11

Hydrocarbon Monitoring in the Mesozoic of Hole 416A

\begin{tabular}{|c|c|c|c|c|c|c|}
\hline Core & $\begin{array}{l}\text { Interval } \\
\text { below } \\
\text { Sea Level } \\
\text { (m) }\end{array}$ & Fluor. & GQF & $\begin{array}{l}\mathrm{CH}_{4} \\
(\%)\end{array}$ & $\mathrm{C}_{1} / \mathrm{C}_{2}{ }^{+}$ & Pyrolysis Data \\
\hline $416 \mathrm{~A}-5$ & $4957-4967.5$ & None & 3 & $10.7 *$ & $3100^{*}$ & - \\
\hline $416 \mathrm{~A}-6$ & $5094-5099.5$ & None & 3 & $8.7 *$ & $5118^{*}$ & $\begin{array}{l}\text { Very little generated hydrocarbons; } 0.02-0.006 \\
\text { potential hydrocarbons kerogen type } 3 ; \text { immature }\end{array}$ \\
\hline $416 \mathrm{~A}-7$ & $5194.5-5296$ & None & 1 & 0.11 & - & As above \\
\hline $416 \mathrm{~A}-8$ & $5293-5321.5$ & None & 0 & - & - & As above \\
\hline $416 \mathrm{~A}-9$ & $5379-5388$ & None & 0 & $<0.0005$ & - & As above \\
\hline $416 \mathrm{~A}-10$ & $5388.4-5397.8$ & None & 1 & 0.06 & - & As above \\
\hline $416 \mathrm{~A}-11$ & $5397.8-5407.3$ & None & 1 & $\begin{array}{l}0.06 * \\
0.04\end{array}$ & 120 & As above \\
\hline $416 \mathrm{~A}-12$ & $5407.3-5416.8$ & None & 1 & $\begin{array}{l}0.17 * \\
0.09\end{array}$ & $122 *$ & As above \\
\hline $416 \mathrm{~A}-13$ & $5416.8-5425.4$ & None & 1 & $\begin{array}{l}0.08^{*} \\
0.03\end{array}$ & $200^{*}$ & As above \\
\hline $416 \mathrm{~A}-14$ & $5426.4-5435.9$ & None & 1 & $\begin{array}{l}0.08^{*} \\
0.12\end{array}$ & $150 *$ & As above \\
\hline $416 \mathrm{~A}-15$ & $5435.9-5445.5$ & None & 1 & $\begin{array}{l}0.75^{*} \\
0.02\end{array}$ & $250^{*}$ & As above \\
\hline $416 A-16$ & $5445.5-5455$ & None & 1 & $\begin{array}{l}0.19 \\
0.008\end{array}$ & $345^{*}$ & As above \\
\hline $416 \mathrm{~A}-17$ & $5455-5464.5$ & None & 1 & $\begin{array}{l}0.09^{*} \\
0.03\end{array}$ & $160 *$ & $\begin{array}{l}\text { Not measured; very little generated hydrocarbons; } \\
\text { small potential for hydrocarbons; kerogen type } 3 \text {; } \\
\text { maturity increasing slightly, but still immature }\end{array}$ \\
\hline $416 \mathrm{~A}-18$ & $5464.5-5474$ & None & 1 & $\begin{array}{l}0.09 * \\
0.01\end{array}$ & $330 *$ & As above \\
\hline $416 A-19$ & $5474-5480.5$ & None & 1 & $\begin{array}{c}0.09 * \\
0.02-0.06\end{array}$ & $236^{*}$ & As above \\
\hline $416 \mathrm{~A}-20$ & $5480.5-5490$ & None & 1 & $\begin{array}{l}0.15^{*} \\
0.007\end{array}$ & $263 *$ & As above \\
\hline $416 \mathrm{~A}-21$ & $5493-5502.5$ & None & 1 & $\begin{array}{l}0.07 * \\
0.02\end{array}$ & $86 *$ & As above \\
\hline $416 \mathrm{~A}-22$ & $5502.5-5512.1$ & None & 1 & $\begin{array}{l}0.23 * \\
0.03\end{array}$ & $150 *$ & As above \\
\hline $416 \mathrm{~A}-23$ & $5512.1-5521.6$ & None & $0-1$ & $0.15 *$ & $149 *$ & As above \\
\hline $416 \mathrm{~A}-24$ & $5521.6-5530.7$ & None & 1 & $\begin{array}{l}0.11 * \\
0.004\end{array}$ & $122 *$ & As above \\
\hline $416 \mathrm{~A}-25$ & $5530.7-5539.2$ & None & 1 & $\begin{array}{l}0.08 * \\
0.006\end{array}$ & $124 *$ & As above \\
\hline $416 A-26$ & $5540.2-5549.7$ & None & 1 & $\begin{array}{l}0.09 * \\
0.008\end{array}$ & $157 *$ & As above \\
\hline $416 \mathrm{~A}-27$ & $5549.7-5594.4$ & None & 1 & 0.008 & - & As above \\
\hline $416 \mathrm{~A}-28$ & $5594.4-5568.9$ & None & 1 & $\begin{array}{l}0.04^{*} \\
0.005\end{array}$ & $147 *$ & As above \\
\hline $416 \mathrm{~A}-29$ & $5568.9-5578.2$ & None & 1 & $\begin{array}{l}0.04 * \\
0.004\end{array}$ & $59 *$ & As above \\
\hline $416 \mathrm{~A}-30$ & $5578.2-5587.6$ & None & 1 & $\begin{array}{l}0.04^{*} \\
0.008\end{array}$ & $69 *$ & As above \\
\hline $416 A-31$ & $5587.6-5597.1$ & None & 0 & $0.02 *$ & $130^{*}$ & As above \\
\hline $416 A-32$ & $5597.1-5606.6$ & None & 0 & $0.05^{*}$ & $81 *$ & As above \\
\hline $416 \mathrm{~A}-33$ & $5606.6-5609.8$ & None & 0 & $<0.0005$ & - & As above \\
\hline $416 \mathrm{~A}-34$ & $5609.8-5619.4$ & None & 0 & $0.12 *$ & $120^{*}$ & As above \\
\hline $416 \mathrm{~A}-35$ & $5619.4-5628.4$ & None & 0 & $0.02 *$ & - & As above \\
\hline
\end{tabular}


TABLE 11 - Continued

\begin{tabular}{|c|c|c|c|c|c|c|}
\hline Core & $\begin{array}{l}\text { Interval } \\
\text { below } \\
\text { Sea Level } \\
(\mathrm{m})\end{array}$ & Fluor. & GQF & $\begin{array}{l}\mathrm{CH}_{4} \\
(\%)\end{array}$ & $\mathrm{C}_{1} / \mathrm{C}_{2}+$ & Pyrolysis Data \\
\hline $416 \mathrm{~A}-36$ & $5628.4-5638$ & None & 0 & $0.01 *$ & $160^{*}$ & As above \\
\hline $416 \mathrm{~A}-37$ & $5638-5648$ & None & 0 & $<0.0005$ & - & - \\
\hline $416 \mathrm{~A}-38$ & $5648-5653$ & None & 0 & $<0.0005$ & - & Too small to measure \\
\hline $416 \mathrm{~A}-39$ & $5653.7-5657.5$ & None & 0 & - & - & - \\
\hline $416 \mathrm{~A}-40$ & $5657.5-5666.9$ & None & 0 & $\begin{array}{c}<0.0005 \\
0.02 *\end{array}$ & $100 *$ & $\begin{array}{l}\text { No generated hydrocarbons; very small potential } \\
\text { for hydrocarbons; mature; probably type } 3 \\
\text { kerogen }\end{array}$ \\
\hline $416 \mathrm{~A}-41$ & $5666.9-5676.3$ & None & 0 & $<0.0005$ & - & As above \\
\hline $416 \mathrm{~A}-42$ & $5676.3-5685.4$ & None & 0 & $<0.0005$ & - & As above \\
\hline $416 \mathrm{~A}-43$ & $5685.4-5694.4$ & None & 1 & 0.003 & - & As above \\
\hline $416 \mathrm{~A}-44$ & $5694.9-5704.2$ & None & 0 & - & - & $\begin{array}{l}\text { No generated hydrocarbons; very small potential } \\
\text { for hydrocarbons; mature; probably type } 3 \\
\text { kerogen }\end{array}$ \\
\hline $416 \mathrm{~A}-45$ & $5704.2-5713.6$ & None & 0 & - & - & As above \\
\hline $416 \mathrm{~A}-46$ & $5713.6-5723$ & None & 0 & - & - & As above \\
\hline $416 \mathrm{~A}-47$ & $5723-5732.5$ & None & 0 & - & - & As above \\
\hline $416 \mathrm{~A}-48$ & $5732.5-5742.1$ & None & 0 & $0.016^{*}$ & $235^{*}$ & As above \\
\hline $416 \mathrm{~A}-49$ & $5742.1-5751.6$ & None & 0 & $0.03 *$ & $252 *$ & As above \\
\hline $416 \mathrm{~A}-50$ & $5751.6-5761$ & None & 0 & 0.03 & 195 & As above \\
\hline 416A-51 & $5761-5770.4$ & None & 0 & 0.05 & 248 & As above \\
\hline $416 \mathrm{~A}-52$ & $5770.4-5779.8$ & None & $0-1$ & $0.05 *$ & $240 *$ & Very poor potential; very little generated \\
\hline $416 \mathrm{~A}-53$ & $5779.8-5789.2$ & None & 1 & $0.006 *$ & - & - \\
\hline $416 \mathrm{~A}-54$ & $5789.2-5798.6$ & None & - & - & - & - \\
\hline $416 \mathrm{~A}-55$ & $5798.6-5808$ & None & - & - & - & - \\
\hline $416 \mathrm{~A}-56$ & $5808-5817.5$ & None & - & - & - & - \\
\hline $416 \mathrm{~A}-57$ & $5817.5-5827$ & None & - & - & - & Very poor potential; very little generated \\
\hline
\end{tabular}

*Sample taken after core lay one or more hours on the rack.

Kimmeridgian. The Oxfordian and pre-Oxfordian history of the basin of course still remains nearly unknown.

The evolution of the basin is dominated by the influence of terrigenous sedimentation. Purely pelagic sediments are a rarity, hemipelagic sediments are minor, and turbidites are by far the most common type of sediments encountered in the entire column, from Tithonian to Pleistocene.

The oldest recovered sediments are of Tithonian age. The corresponding interval on the seismic profiles is probably just above and very close to the blue reflector. The Mesozoic rocks consist of distal turbidites of a dual nature. Most of the graded sequences are composed of terrigenous clastics such as quartzose sandstone, siltstone, and mudstone, but about a third of the sequence is made of redeposited calcareous material having its origin on the continental shelf and slope. Truly pelagic intervals between turbidite sequences are almost invisible, and bioturbation is rare. However, the microfauna, in particular the benthic foraminifers indicates that perennial deep-water sediments were present. Some of the brown mudstones are probably in situ pelagic sedi- ments, but much of this material has been redeposited to an extent by turbidity currents. The environment of deposition is that of the lowermost continental rise, near the transition between the rise and an abyssal plain, an environment comparable to that observed today at the site. The environment was well oxygenated, as attested by the red and brown colors. The depth of deposition of these uppermost-Jurassic sediments is difficult to estimate, but they were deposited below the CCD, as attested by the microfauna.

Terrigenous material probably arrived at a fairly constant rate from a distant source, whereas the carbonate influx was more variable and came from closer sources, probably shallow-water platforms (ooids, pellet-lumps) and a deeper-water shelf and continental slope (aptychi, calpionellids, and clasts of calpionellid limestones). The bulk of the calcareous material is clearly redeposited, and even the rather homogeneous-looking micritic limestone beds rich in calpionellids are clearly part of turbidite sequences. Many of the displaced fossils in both terrigenous and calcareous sequences are of bathyal rather than neritic origin, and redeposition of these components might have involved only relatively minor trans- 
port, as attested by the very good state of preservation of fragile loricae of calpionellids, observed not only in recrystallized micrites but also in the coarse fractions of calcareous mudstones. Some turbidity currents that came from shailow regions entrained bathyal components as the currents moved down the continental slope; other currents may have started at bathyal depths, on the slopes above Site 416 .

The same environment prevailed during the earliest Cretaceous, during the Berriasian and early Valanginian. The site of deposition, although distal (perhaps the outermost part of a deep-sea fan), was gradually prograded, and by the late Valanginian the turbidites reflect more-proximal conditions. Calcareous material decreases drastically, and the terrigenous quartzose facies becomes predominant. The rate of sedimentation deduced from the biostratigraphic age assignments (assuming the van Hinte time scale) increases from about $10 \mathrm{~m} / \mathrm{m} . \mathrm{y}$. in the uppermost Jurassic and Berriasian to about $55 \mathrm{~m} / \mathrm{m} . y$. in the lower Valanginian; in the upper Valanginian it reaches about $70 \mathrm{~m} / \mathrm{m} . \mathrm{y}$. The proportions of Bouma units A to E suggest that the most-distal conditions prevailed during the late Valanginian, but the minimum average bed thickness occurs in the lower Valanginian. The three different times for "minimum" sedimentation rates derived from these three different classes of data suggest that caution must be used in trying to assign precise rates of accumulation in this part of the stratigraphic column, where radiometric dates are scarce.

Background "perennial" sediment is almost nonexistent. The tops of the two types of turbidite cycles are different (zeolitic mudstone, calcareous mudstone), although there may be an admixture of background perennial material. However, with more than 5000 beds deposited in about $8 \mathrm{~m} . \mathrm{y}$., the amount of pelagic sediment between turbidity currents can be expected to be very small. A tendency toward decreasing carbonate contents at the top of calcareous cycles and the scarcity of calcareous plankton and nannoplankton suggest accumulation below the CCD.

The more-terrigenous phase of turbidite deposition might correlate with the first orogenic phase recorded in the Western High Atlas in the latest Jurassic in Southwest Morocco (Faure-Muret, Choubert, and Kornprobst, 1971).

Toward the end of the Hauterivian, turbidity currents carrying terrigenous sand, silt, and mud down to the base of the continental rise abruptly decreased in frequency. Occasional coarse clastics were still being carried down to the basin, as evidenced by graded beds of sandstone and pebbles, but the regularity and the frequency of the turbidites were greatly diminished. Hemipelagic shale and claystone make up most of the sediments of Barremian through Albian age. Correspondingly, the rate of accumulation decreased very abruptly from an average of $65 \mathrm{~m} / \mathrm{m}$.y. to about 6 to $12 \mathrm{~m} / \mathrm{m}$.y. during the Barremian, Aptian, and Albian.

Post-Albian Cretaceous sediments are not present at Site 416 , probably by reason of erosion in post-Cenomanian, pre-Cenozoic times. The seismic-profiler data show an erosional unconformity at the red reflector, younger and younger beds appearing beneath the unconformity both south and east of Site 416 . The slumped and displaced beds drilled at Site 415 in the Cenomanian are missing at Site 416. The underlying causes for this erosion and sliding from the Late Cretaceous to the earliest Cenozoic are uncertain. Post-Turonian Cretaceous sediments have a lesser areal extent on the adjacent margin of Morocco (Société Chérifienne des Pétroles, 1966) than the underlying Cretaceous beds, and this time of renewed deformation and uplift of parts of the westernmost High Atlas may have steepened the continental slopes and led to erosion, slumping, and sliding of newly deposited middle Cretaceous muds, while the rapidly subsiding basins closer inshore trapped most terrigenous sediment.

The Cretaceous and Jurassic rocks on the continental rise were also gently folded at this time, although it is not certain whether folding involved the basement rocks or not. Deformation by the same stress system that produced uplift and warping in the High Atlas may have affected the continental rise, or the structures may be the result of gravity sliding off a regional uplift. The two mechanisms are not mutually exclusive.

The erosional surface that cuts across the folded middle-Cretaceous strata (marked by a horizon just beneath the red reflector) probably lay bare for a long period of time, and a hard-ground likely developed on this surface, as suggested by the very large spike in the gammaray log, as well as by kicks on the sonic and density logs. The same gamma-ray spike appeared also at Site 415, at what we interpreted as the Cretaceous/Tertiary boundary. Coring at Sites 370, 416, and 415 failed to recover any material from this layer, which might contain in highly condensed form the only record or the Late Cretaceous history of this region.

Cenozoic sedimentation began very slowly in the late Paleocene, with calcareous clay and marl deposited at about $1 \mathrm{~m} / \mathrm{m} . \mathrm{y}$. over the surface of unconformity. These sediments are probably pelagic and record an environment a little above the CCD. The paleodepth, using normal subsidence and density curves, was probably about 3500 to 4000 meters. The site was protected from important continental clastic influences, and the record on the adjacent continents (Société Chérifienne des Pétroles, 1966) is also one of lacunae in the early Cenozoic.

A small hiatus at the Paleocene/Eocene boundary marks a large change in depositional facies. The change is signaled on the Schlumberger logs and seismic-profiler records by the red reflector. During the early Eocene and most of the middle Eocene, this part of the lower continental rise was supplied with relatively coarse clastics, including gravels, brought down by turbidity currents. This regime was widespread, extending south to Site 415 , but thickness of the deposits is irregular. Near Site 416, the coarse turbidites appear ponded; farther south, they appear to be more lenticular and they tend to fill in and smooth out relief on the underlying surface of unconformity (see chapter on underway geophysics, this volume). The clastic components in the turbidites are dominantly terrigenous (quartz, plant debris, 
etc.), but they include glauconite, benthic foraminifers, and nannofossils, indicating entrainment into the currents of materials from the submarine realm as well. The average rate of accumulation of these sediments was about $27 \mathrm{~m} / \mathrm{m}$.y. In cores from this unit from Site 370 , porcellanite nodules are fairly common; these and rare radiolarians suggest that relatively fertile waters overlay the site for the first time since at least the Late Jurassic. The calcite in the rocks is partly in the form of nannofossils and foraminifers, but largely in the form of cement, which accounts for the relatively high average velocity of sound in this unit $(2.11 \mathrm{~km} / \mathrm{s})$.

Near the close of the middle Eocene, the coarseness of material arriving at Sites 370 and 416 decreased, and sand-silt-marl/mud turbidite sequences replace the coarsegrained sequences below. The change is interpreted simply as a change from a more-proximal to a more-distal turbidite environment, and it may or may not have any tectonic significance, because it is possible that changes in the physiography of the submarine canyon-fan system could account as well for the change in facies.

An unusual feature of the change is its abruptness. The tan seismic reflector corresponds with this contact, and it is very prominent as seen on the various downhole logs. A surprising feature of the stratigraphy is the fact that the lithologic change lies only 30 meters below a probable hiatus that separates the middle Eocene from the uppermost lower Oligocene. This hiatus is not marked by any distinctive feature on the electric logs, nor does the description of Core 370-6, taken at this level, indicate any major change in lithology at this boundary.

The same general distal-turbidite regime prevailed until about the end of the middle Miocene, but stratigraphic control is poor at the top of the sequence because of the wide spacing and uncertain placement of cores. During all this time there were variations in conditions of supply, and the fluctuations on the sonic, gamma-ray, and density logs doubtless reflect some of these. The gamma-ray log suggests a gradual but fitful decrease in clay content upward. Common diatoms and radiolarians attest to continuing fertility of the overlying waters, but any relationship of the carbonate content to a dissolution facies is difficult to assess, because what little cored material we have mainly appears to represent turbidite layers.

Somewhere within this distal-turbidite lithosome is the brown seismic reflector, but it cannot be identified clearly, either in the cores or on the down-hole logs. This is a little disconcerting, considering the wide extent of this reflector, but our core control is so scattered that there easily could be a significant change, (e.g., in thickness of turbidite layers) without our seeing it. At Site 415 the reflector appears to correspond to the top of a sequence of coarse-grained sandstone layers near the boundary between the middle and lower Miocene, and the reflector indeed may be at that biostratigraphic level at Sites 370 and 416: reasonable velocities constrain the interval to about 185 to 215 meters at Site 416 .

\section{Analysis of Cyclicity in the Cenozoic Turbidites}

Because turbidites are almost omnipresent in the sediment sampled at Site 416, we have put some emphasis on their presence and distribution. To facilitate description of the cores aboard ship, and to permit statistical studies of the composition and stratigraphic distribution of the turbidites throughout the cored section, we have described them in terms of the conventional Bouma sequence.

For this purpose, the dark-olive-green mudstones to marlstones were lumped as a D interval, and the gray (more pelagic) intervals were identified as E, although we recognize that this approach may be an oversimplification. The A, B, and C intervals were defined in the normal way. Precise observations in this format were first used throughout Core 416A-2, and the data were used to evaluate some approximate indices of proximity for the sequence-namely, the gross sand/shale ratio and the $A B C$ Index $(A+1 / 2 B$; Walker, 1970), where A and $\mathrm{B}$ are the percentages of beds starting with the $\mathrm{A}$ and B intervals, respectively. Data from the whole sequence gave an $\mathrm{ABC}$ index of 41.5 , and a sand/shale ratio of 0.23 . However, several beds start with a sand layer only some $5 \mathrm{~mm}$ thick. Moreover, the coarse fraction contains a high proportion of foraminifers which need not have been transported all the way from the source of a given turbidity current. Both factors could tend to boost the obtained values. As a control, the two indices were recalculated ignoring sand layers thinner than 5 $\mathrm{mm}$. The $A B C$ index then fell to 26.7, whereas the sand/shale ratio $(0.22)$ was hardly changed.

Whichever values are most truly representative, the sequence appears to belong to the distal end of the conventional turbidite facies spectrum (Facies D of Mutti and Ricci-Lucchi, 1972) and would appear to represent the outer-fan or abyssal-plain environment of currently accepted outcrop-based models.

The low sand/shale ratio, in particular, serves to distinguish this sequence from Mutti and Ricci-Lucchi's facies E, which is believed to characterize interchannel environments on the upper fan. Thus, we prefer to postulate an outer-fan and relatively unchanneled site of deposition for the sequence recovered in Core 416A-2. The same conclusions probably hold for Core 416A-3, in which too many bed contacts seemed to have been broken during coring to justify measurement.

At a depth of about 100 meters sub-bottom, probably at a level near the contact between middle and upper Miocene, the turbidites give way to nannofossil marl and ooze deposited between the lysocline and the CCD. This facies prevailed until sometime during the late Pliocene, dissolution effects perhaps becoming more pronounced as time progressed. The rate of accumulation was about $10 \mathrm{~m} / \mathrm{m}$.y. Diatoms are absent, and radio- 
larians are rare and fragmented in this unit, suggesting that the fertility of waters may have decreased after the middle Miocene.

The uppermost part of the stratigraphic column is a thin $(0.5-\mathrm{m})$ layer of nannofossil ooze of late-Pleistocene age, lying on a hiatus that spans the early Pleistocene and part of the late Pliocene. Because Site 416 is in a broad, north-trending valley parallel to the continental margin, it may be the locus of erosion, or at least an area of non-deposition kept clean by bottom currents. The Pleistocene fossils are well preserved and suggest accumulation above the lysocline, in spite of the actual depth (4200 meters). Perhaps the Pleistocene material has been displaced from shallower water.

\section{Seismic Reflectors and Down-Hole Logs}

One of the most satisfying results of operation at Site 416 was the set of Schlumberger logs we obtained, and one of the bitterest disappointments was our failure to $\log$ the entire depth of the hole. For the first time at a deep-water site, we could pick seismic reflectors precisely off the down-hole logs, and we were not forced into the usual iterative circling around the most plausible solution. Two reflectors, the tan and the red, stand out well on the logs, and both of these are at unsuspected locations. The tan reflector is only 30 meters below a large hiatus, and the red reflector is at a minor hiatus, only 20 meters above the biggest hiatus in the column. Without the logs, it is certain that we would have placed the reflectors at the important unconformities.

On the other hand, even with the logs, we were unable to identify the brown reflector, which is very prominent on all reflection profiles in the region.

The sequence of reflectors at Site 416 is thought to be as follows:

Brown 0.225 second; $\sim 200$ meters; approximately at the boundary between the middle and lower Miocene, within a section of distal turbidites

Tan $\quad 0.485$ second; 457 meters; at the top of a series of well-cemented, coarse-grained turbidites of the middle and early Eocene

Red $\quad 0.66$ second; 642 meters; at a small hiatus between lower-Eocene coarse-grained turbidites and upper-Paleocene nannofossil-bearing pelagic claystone

Olive $\quad 0.87$ second; $834-880$ meters; near the upper limit of coarse-grained turbidites, between the base of the Aptian and the base of the Barremian

Blue $\quad 1.43$ second; >1624 meters (1660-1750 meters); probably in Upper Jurassic carbonaterich turbidites or at one top of a more-pelagic interval (shales or carbonates)

\section{Organic Geochemistry}

The sequence of strata at Site 416 provided the shipboard organic geochemists with an unusually good opportunity to study the diagenesis of organic material as a function of age, depth of burial, type of organic material, and lithofacies, and the chemists took full advantage of this opportunity. The results show first that essentially all the organic matter buried in the sediments from Jurassic to Pleistocene time was derived from land plants, mainly higher plants. The concentrations of this material are mainly very low, averaging about 1.2 per cent in the Cenozoic, and 0.8 per cent in the Cretaceous. The trend in the Cretaceous is toward decrease in concentrations with depth. Turbidite cycles commonly show considerable variation from the coarse to the fine part of a cycle: in some beds the basal sands are rich in plant fragments-even some translucent amber grains were found-while in other beds the finer-grained, more-pelagic end of the cycle is richer in organic material. With only trivial exceptions, none of the rocks can be considered good source rocks.

The pyrolysis studies show that organic matter above a depth of about 1200 meters is still immature, while below, to the total depth of 1624 meters, the rocks are only at the beginning of the mature stage.

The data on gas concentration and composition show very low concentrations in the uppermost 300 meters, then an increase to nearly 22 per cent at a depth of about 900 meters, followed by a precipitous drop to about 0.5 per cent at 1000 meters, and a gradual dwindling to 0.1 per cent at 1500 meters. The big change comes at the top of the Cretaceous turbidite section, and it may be related to that facies change, but it also corresponds to the base of the gas hydrate-stability zone, calculated by extrapolation of the temperature-log data.

Another interesting feature is the confirmation which the gas data provide on the state of maturation of the organic matter. The relative proportions of the various measured gases (methane, ethane, propane, butane, and pentane) change steadily down the column, until, at about 1200 meters, propane, which is on the threshold of the liquid hydrocarbons, makes its first appearance. At a depth of 1500 meters, pentane constitutes nearly 25 per cent of the $\mathrm{C}_{2}-\mathrm{C}_{5}$ fraction of the sampled gas.

In summary, organic material below a depth of about 1200 meters has matured, and, given sufficient concentration, it would generate petroleum in significant amounts. This is important in two respects: first, because it shows that a stable continental rise is an environment in which the diagenesis of organic matter does proceed to maturity; second, because it warns us that great precautions must always be taken against the possibility of encountering uncontrollable or dangerous quantities of hydrocarbons.

\section{REFERENCES}

Archie, G. E., 1942. The electrical resistivity $\log$ as an aid in determining some reservoir characteristics, Trans. AIME., v. 146, p. 54 . 
Boyce, R. E., 1976. Sound velocity-density parameters of sediment and rock from DSDP drill sites $315-318$ on the Line Islands Chain, Manihiki Plateau, Tuamotu Ridge in the Pacific Ocean. In Schlanger, S. O., Jackson, E. D., et al., Initial Reports of the Deep Sea Drilling Project, v. 33: Washington (U.S. Government Printing Office), p. 695728.

Bukry, D., 1978. Cenozoic coccolith and silicoflagellate stratigraphy, offshore Northwest Africa, Deep Sea Drilling Project, Leg 41. In Lancelot, Y., Seibold, E., et al., Initial Reports of the Deep Sea Drilling Project, v. 41: Washington (U.S. Government Printing Office), p. 689-708.

Cepek, P., 1978. Mesozoic calcareous nannoplankton of the eastern North Atlantic, Leg 41. In Lancelot, Y., Seibold, E., et al., Initial Reports of the Deep Sea Drilling Project, v. 41: Washington (U. S. Government Printing Office), p. $667-681$.

Faure-Muret, A., Choubert, G., and Kornprobst, J., 1971. Le Maroc. Domaine rifain et atlasique. In Tectonique de l'Afrique: Sci. Terre, UNESCO, Paris, no. 6, p. 17-46.

Krasheninnikov, V. A., and Pflaumann, V., 1978. Zonal stratigraphy of Neogene deposits of the eastern part of the Atlantic Ocean to the west off Africa (Deep Sea Drilling Project, Leg 41). In Lancelot, Y., Seibold, E., et al., Initial Reports of the Deep Sea Drilling Project, v. 41: Washington (U.S. Government Printing Office), p. 613-658.

Lancelot, Y., and Seibold, E., 1978. The evolution of the Central Northeastern Atlantic-summary of results of
DSDP Leg 41. In Lancelot, Y., Seibold, E., et al., Initial Reports of the Deep Sea Drilling Project, v. 44: Washington (U.S. Government Printing Office), p. 1215-1245.

Lancelot, Y., Seibold, E., et al., 1978. Initial Reports of the Deep Sea Drilling Project, v. 41: Washington (U.S. Government Printing Office).

Lynch, E. J., 1962. Formation Evaluation. New York (Harper and Row).

Mutti, E., and Ricci-Lucchi, F., 1972. Le torbiditi dell' Appennines settentrionale: introduzione all' analisi delle facies, Mem. Soc. Geo. Ital., v. 11, no. 2, p. 161-199.

Poore, R. Z., and Berggren, W. A., 1974. Pliocene biostratigraphy of the Labrador Sea: calcareous plankton, J. Foram, Res., v. 4, p. 91-108.

1975. Late Cenozoic planktonic foraminiferal biostratigraphy and paleoclimatology of Hatton-Rockall Basin: DSDP Site 46, J. Foram. Res., v. 5, p. 270-293.

Société Chérifienne des Pétroles, 1966. Le bassin du SudOuest Marocain. In Reyre, D. (Ed.), Bassins Sedimentaires du Littoral Africain: New Delhi (Assoc. Serv. Geol. Afr.) p. 5-12.

Thomas, B. D., Thompson, I. G., and Utterback, C. L., 1934. The electrical conductivity of sea water, J. Conseil, Conseil Perm. International Exploration Mer, v. 9, p. 28.

Walker, R. G., 1970. Review of the geometry and facies organization of turbidites and turbidite-bearing basins, Geol. Assoc. Canada, Spec. Paper, no. 7, p. 219-251. 



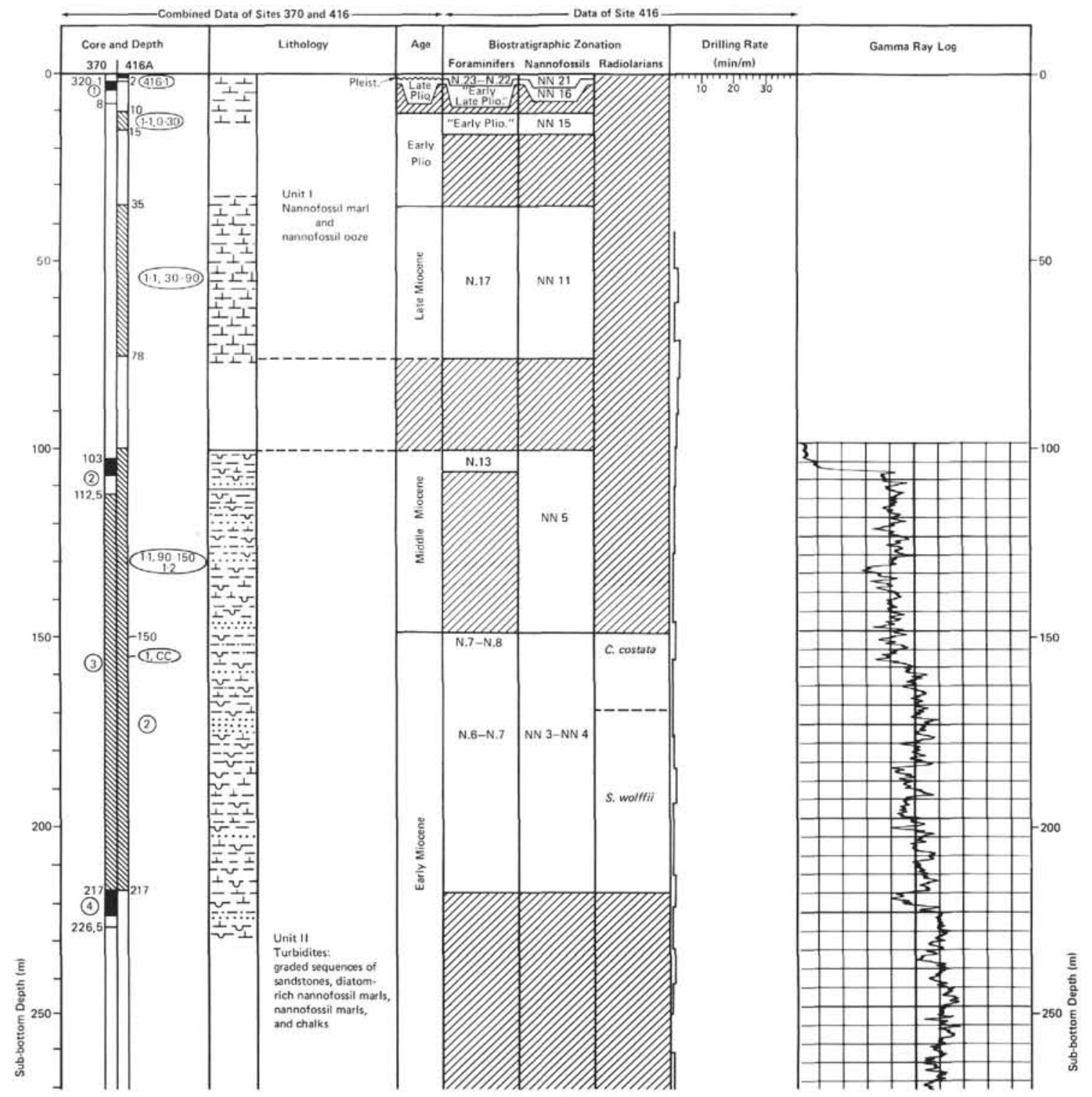



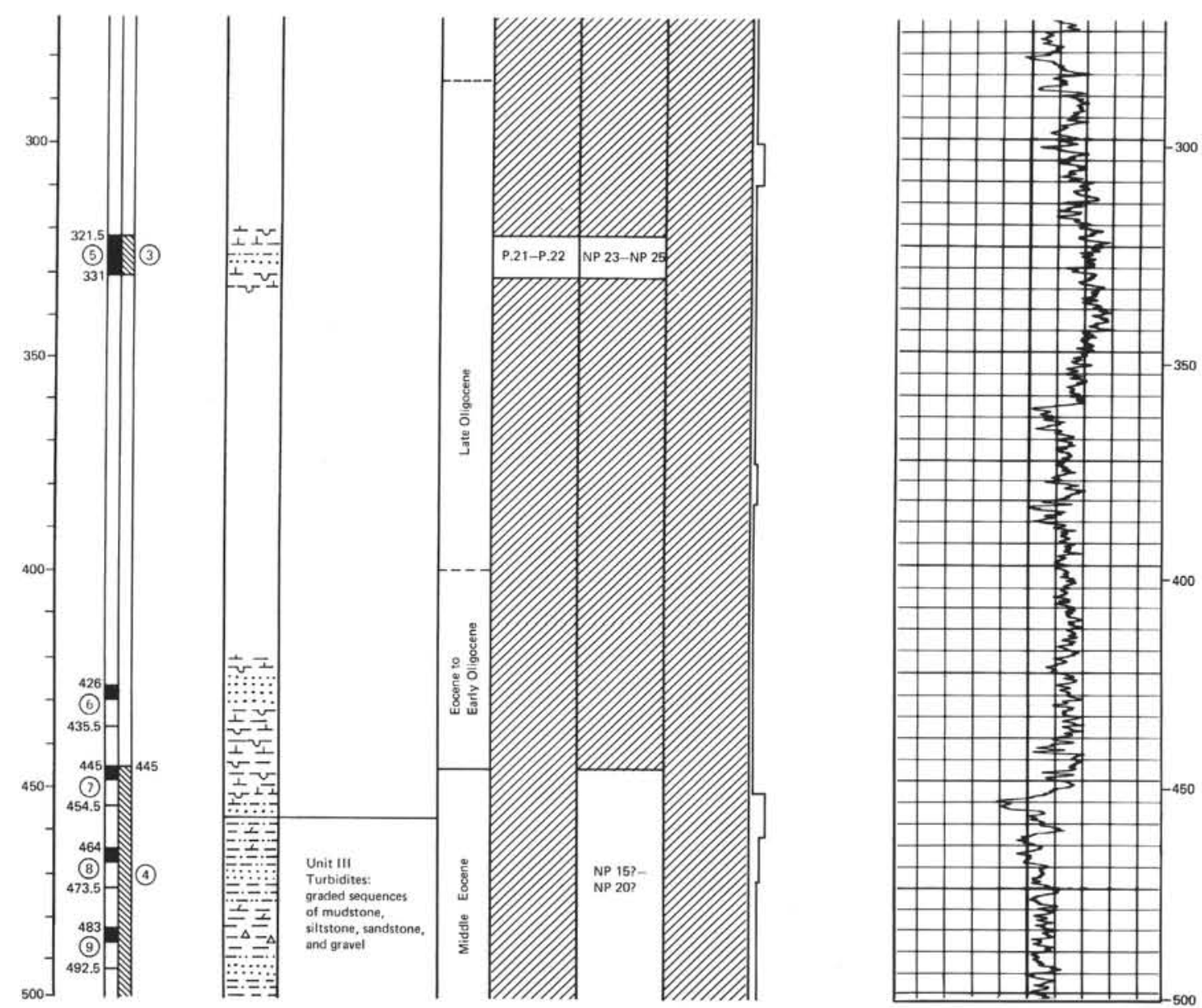

N core at nominal interval

(9) Core No.

Figure 6. Graphic site summary. 


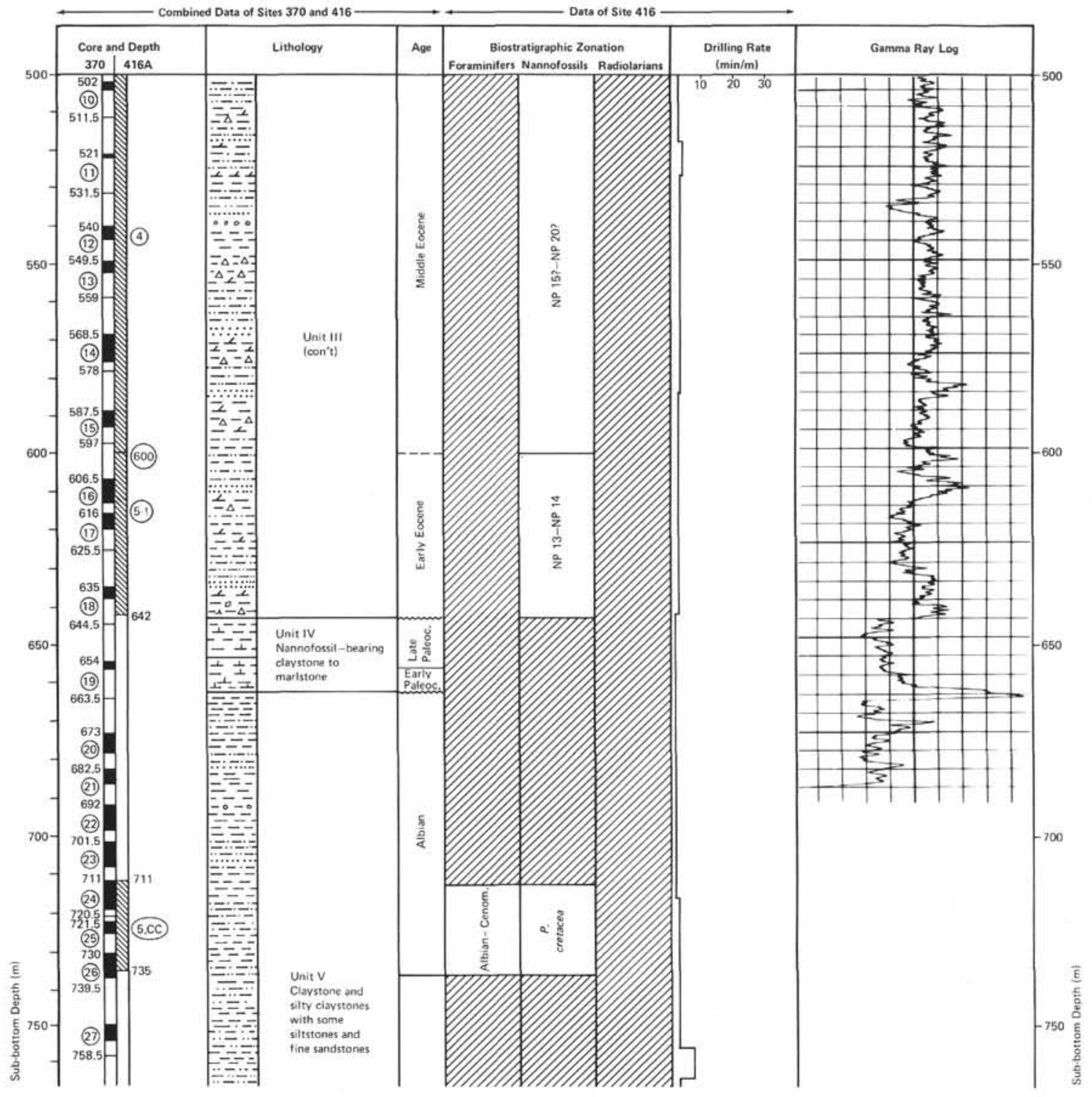



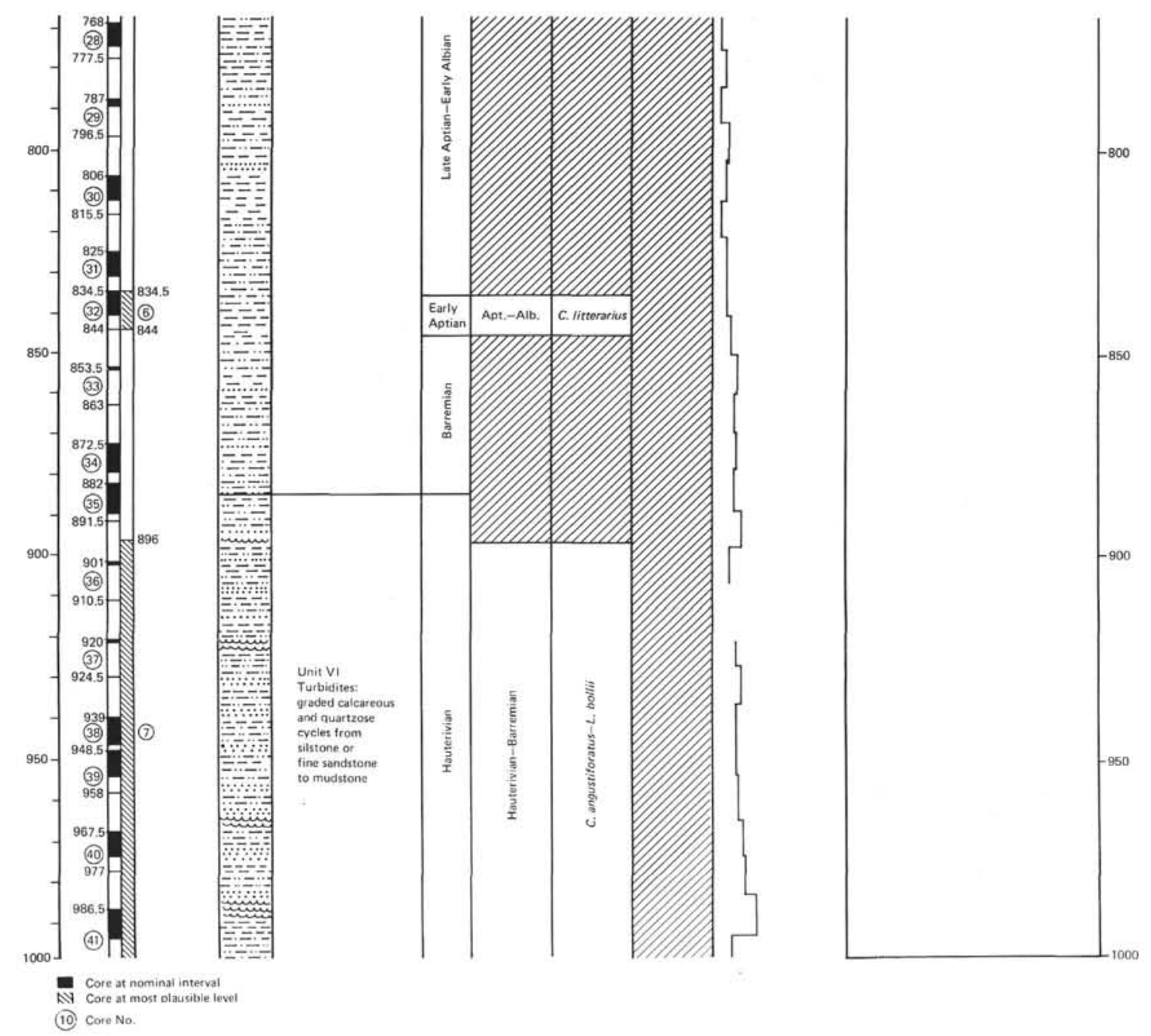

Figure 6. (Continued). 


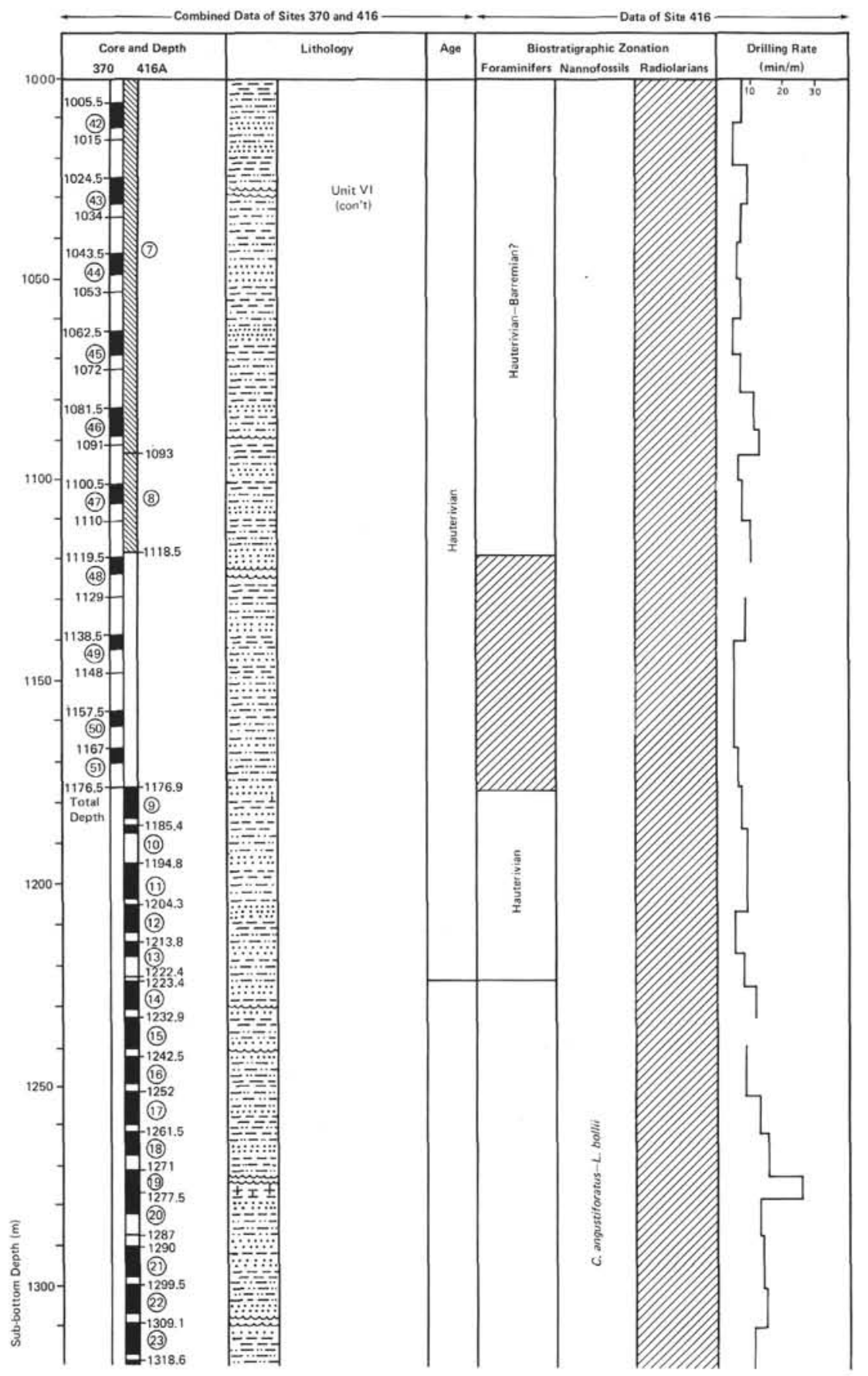




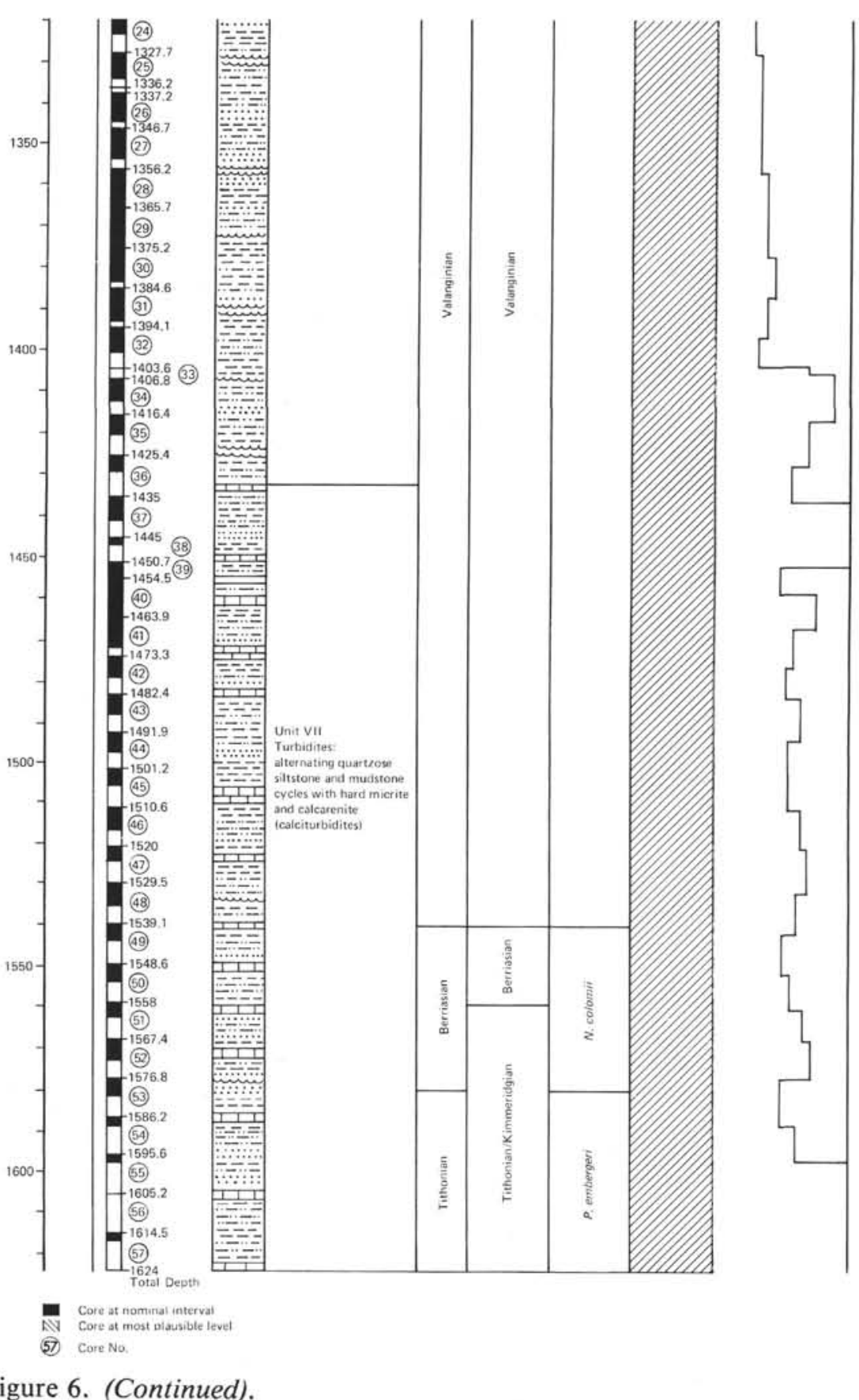




\begin{tabular}{|c|c|c|c|c|c|c|c|c|c|c|c|c|c|c|c|c|c|c|c|c|c|c|c|c|c|}
\hline \multirow[b]{2}{*}{ 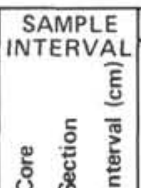 } & \multicolumn{3}{|c|}{ TEXTURE } & \multicolumn{5}{|c|}{ EXOGENIC } & \multicolumn{8}{|c|}{ AUTHIGENIC - DIAGENETIC } & \multicolumn{8}{|c|}{ BIOGENIC } & \multirow[b]{2}{*}{ 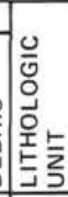 } \\
\hline & $\begin{array}{l}2 \\
\text { w } \\
\text { de }\end{array}$ & $\begin{array}{l}5 \\
\frac{5}{2}\end{array}$ & 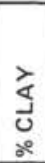 & 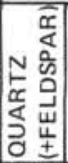 & $\frac{\mathbb{U}}{\Sigma}$ & 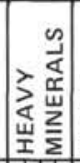 & 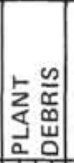 & 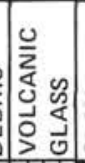 & 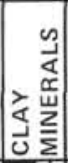 & 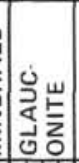 & 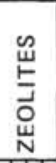 & $\frac{\underset{\sigma}{\tilde{\alpha}}}{\frac{\tilde{\alpha}}{\partial}}$ & 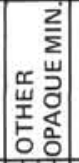 & 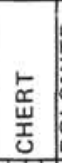 & 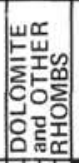 & 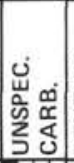 & 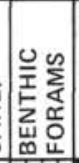 & 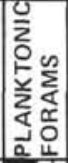 & 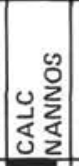 & 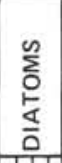 & 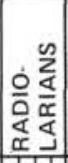 & 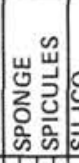 & 岀 & 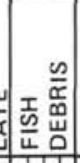 & \\
\hline
\end{tabular}

\section{\begin{tabular}{|l|}
\hline $1 \cdot 1,30$ \\
\hline $1-1,46$ \\
\hline $1.1,47$ \\
\hline 1.119
\end{tabular}}

\begin{tabular}{|c|}
\hline $1-1,47$ \\
\hline $1-1,119$ \\
\hline $\mathrm{A} 1-1,8$ \\
\hline $\mathrm{A} 1-1,15$ \\
\hline
\end{tabular}

\begin{tabular}{|l|}
\hline $\mathrm{A} 1-1,15$ \\
\hline $\mathrm{A} 1-1,30$ \\
\hline
\end{tabular}

\begin{tabular}{|l|}
\hline$A 1-1,52$ \\
\hline$A 1-1,63$ \\
\hline$A 1-1,68$ \\
\hline$A 1-1,74$ \\
\hline
\end{tabular}

A1-1, 74

A1-1, 79

A1-1, 87

A1-1, 88

A1-1, 101

A1 1,108

A1 1,109

A1-1, 111

\begin{tabular}{|l|}
\hline A $1-1,118$ \\
\hline A $1-1,120$ \\
\hline
\end{tabular}

A1-1, 121

A1-1, 123

\begin{tabular}{|l}
$\mathrm{A} 1 \cdot 1,135$ \\
\hline $\mathrm{A} 1 \cdot 2,2$ \\
\hline A $1-2,4$
\end{tabular}

A1-2, 4

A1-2, 6

A1-2, 8

$\mathrm{A} 1-2,12$

A1-2, 20

A1-2, 28

A1.2, 38

A2 $-1,18$

A2-1,27

\begin{tabular}{|c|}
$\mathrm{A} 2-1,40$ \\
\hline $\mathrm{A} 2-1,53$
\end{tabular}

A2-1, 53

A2-1, 56

\begin{tabular}{|l|}
\hline $\mathrm{A} 2 \cdot 1,58$ \\
\hline $\mathrm{A} 2 \cdot 1,92$ \\
\hline
\end{tabular}

\begin{tabular}{|l|}
\hline A2-1, 92 \\
\hline$A 2-1,113$ \\
\hline
\end{tabular}

\begin{tabular}{|c|}
\hline$A 2-1,113$ \\
\hline$A 2-1,124$ \\
\hline
\end{tabular}

A2-1, 129

A2-1, 140

A2-2, 91

A2-2, 99

A2-2, 100

A2.2, 135.5

\begin{tabular}{|l} 
A2-2, 141 \\
\hline A3-1, 100 \\
\hline
\end{tabular}

\begin{tabular}{|l|}
\hline$A 3-1,115$ \\
\hline$A 3 \cdot 3,56$ \\
\hline$A 3-3,57$
\end{tabular}

A3.3,57

A3.3, 63

A3-3, 124

A3-4, 8

A5-1, 6

\begin{tabular}{|l|}
\hline A5-1, 7 \\
\hline A5-1, 20 \\
\hline
\end{tabular}

Figure 7. Visual estimates of sediment composition from smear slides, Site 416. 
SMEAR SLIDE SUMMARY - SITE 416
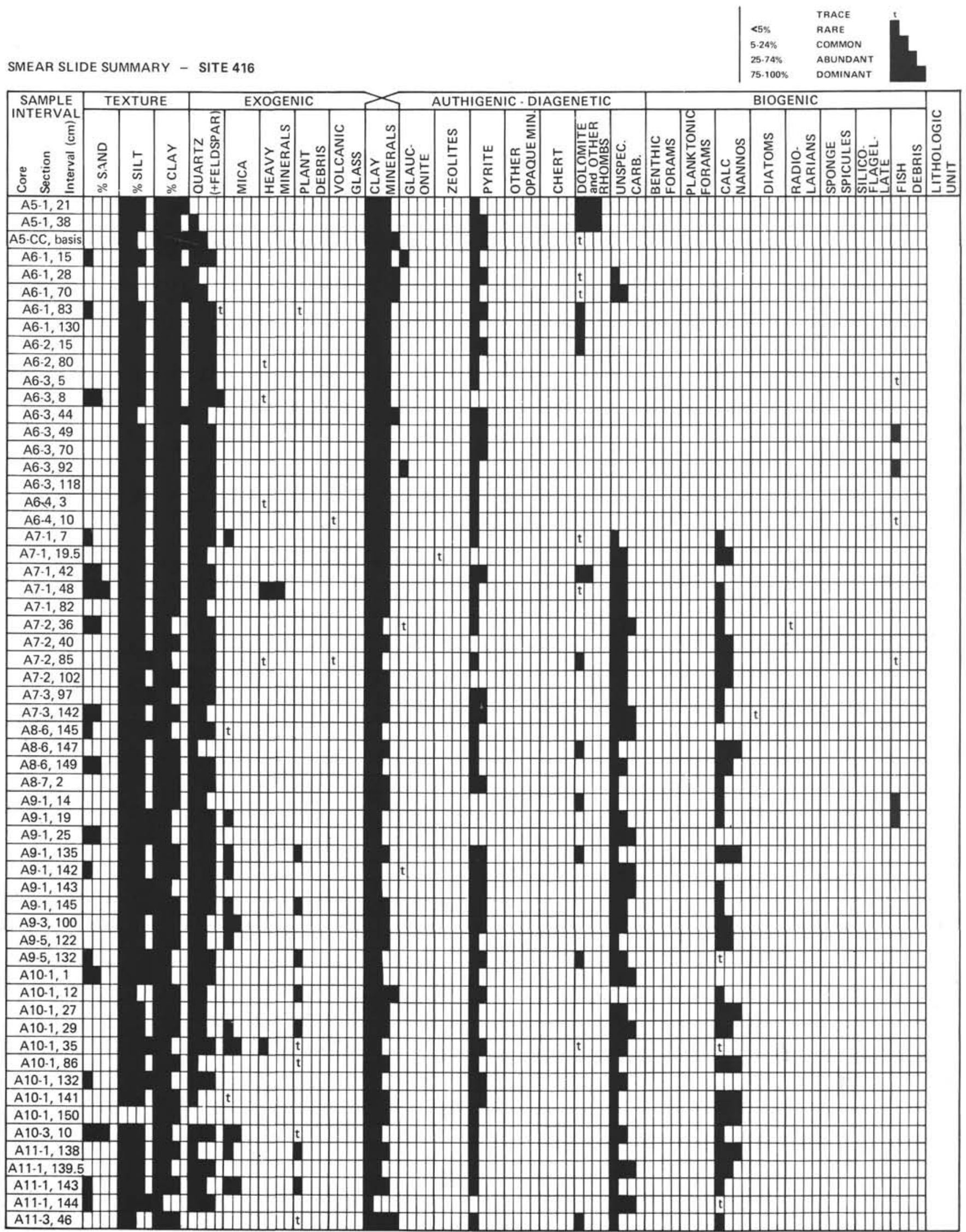

Figure 7. (Continued). 


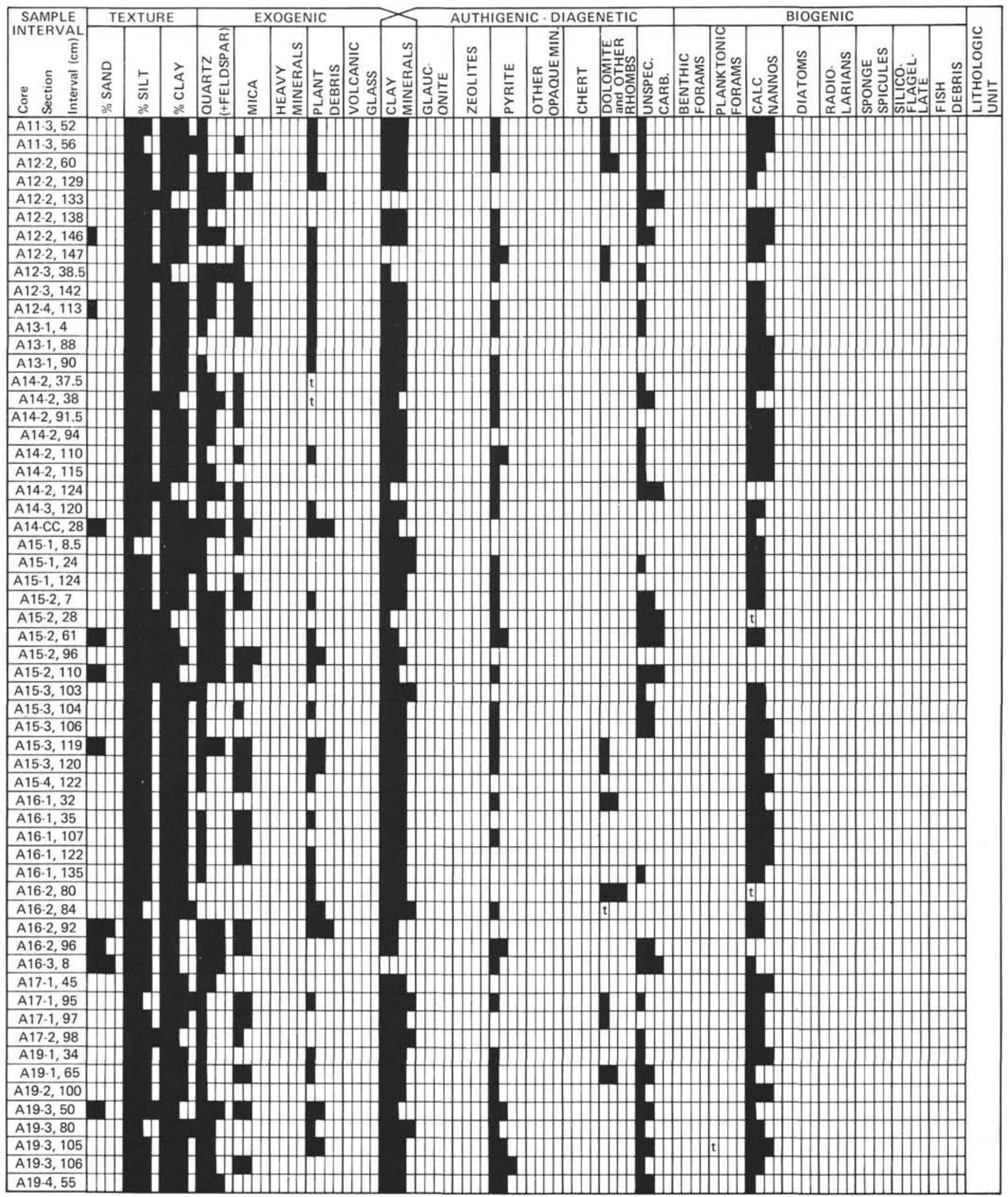

Figure 7. (Continued). 


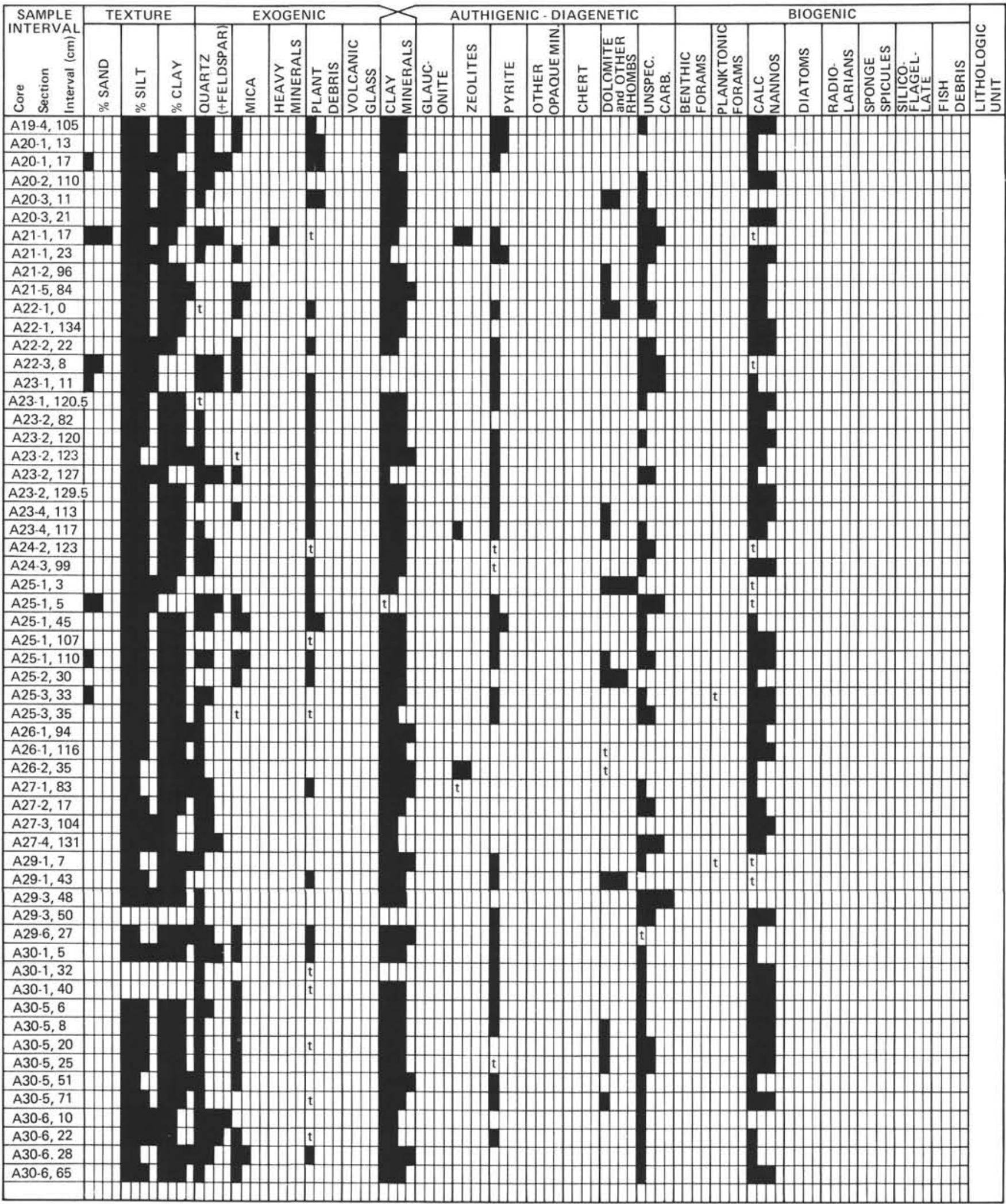

Figure 7. (Continued). 
$25.74 \%$ ABUNDANT

75.100\% DOMINANT

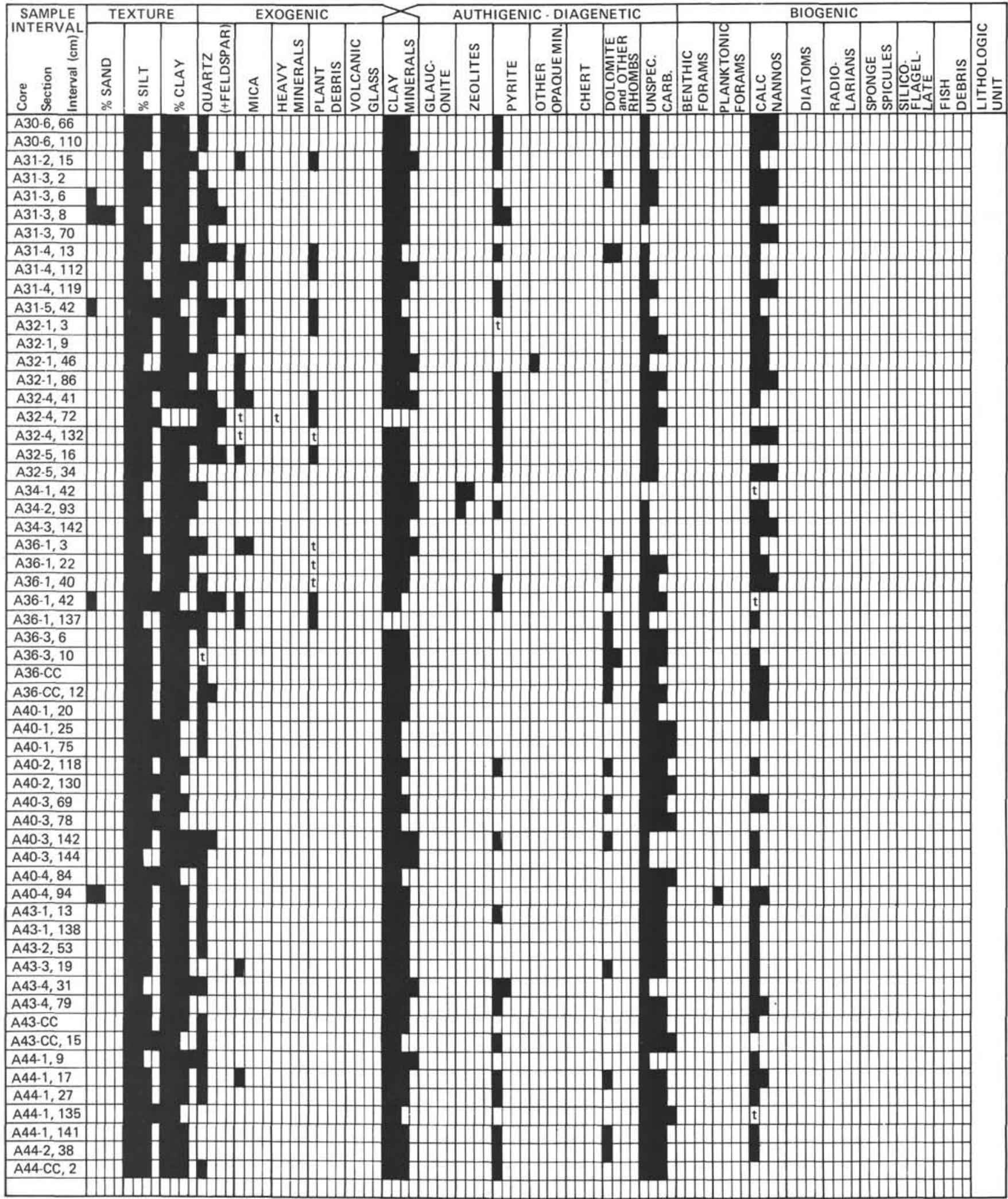

Figure 7. (Continued). 
SMEAR SLIDE SUMMARY - SITE 416
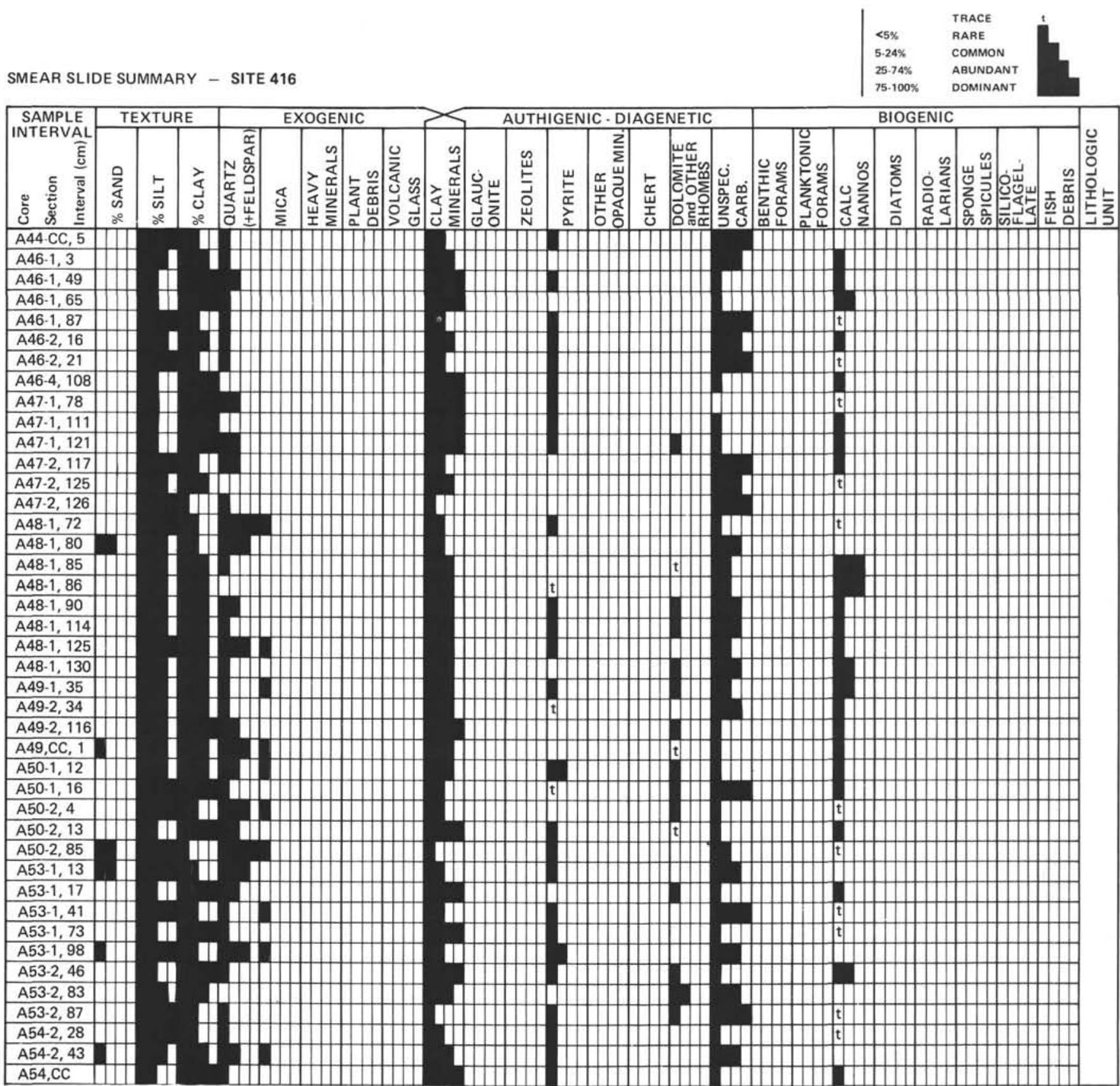

Figure 7. (Continued). 
PHYSICAL-PROPERTIES CORE PLOTS

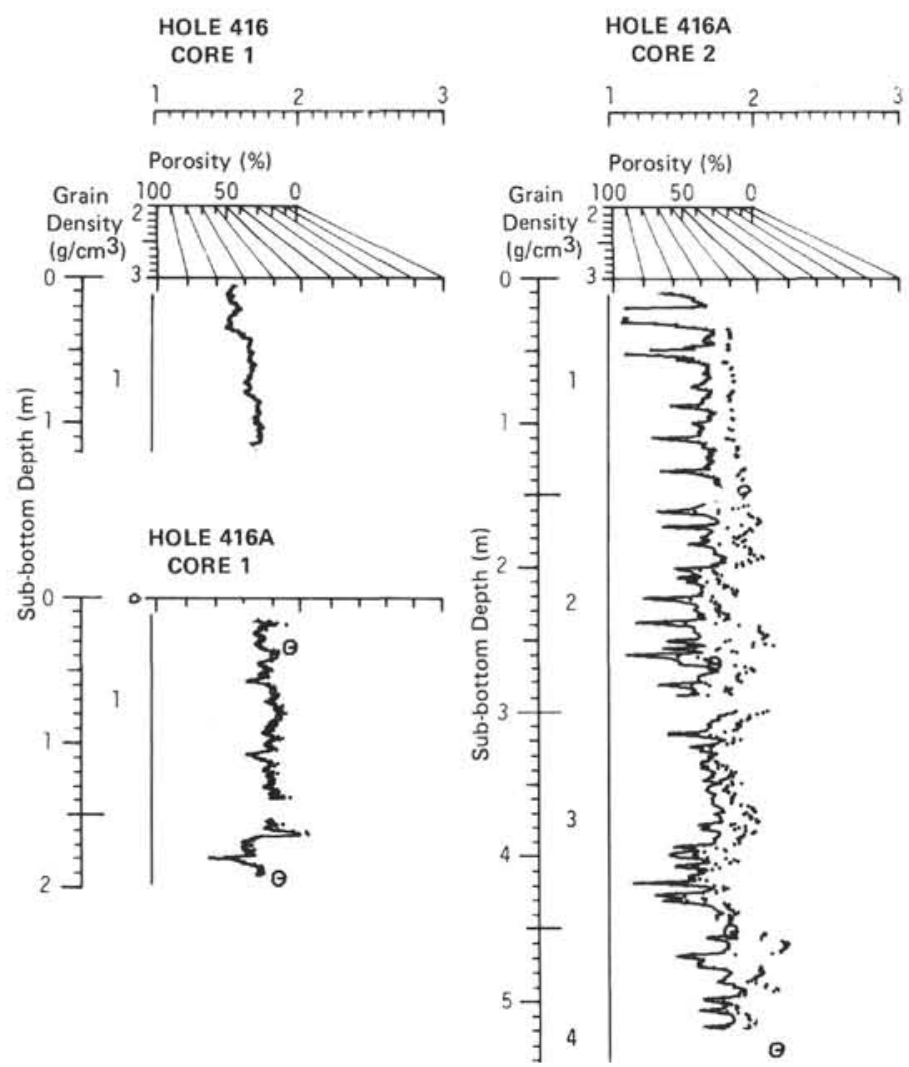

\section{CORE 3}

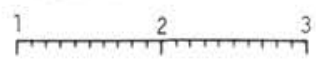

Porosity (\%)

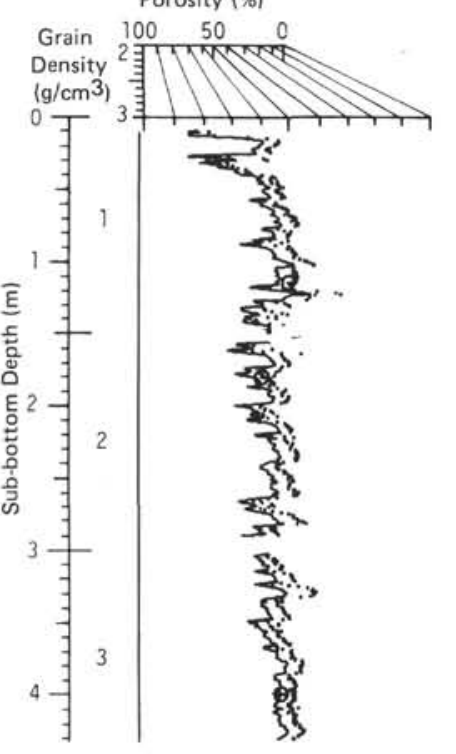

All Leg 50 GRAPE analog computer data has been severely edited for publication. For Leg 50 analog GRAPE data (particularly Site 416), all rock diameters were measured by hand, usually one measurement per $5 \mathrm{~cm}$ core segment. These core segments are very rough and irregular; therefore, when these diameters (and assumption of offset from the famma-ray beam as described by Equation 36 in Boyce, 1976) are applied to the raw GRAPE data, the resulting adjusted data (dotted lines) are subject to huge errors, particularly when small, irregular-diameter core segments are scanned and the calculated (Equation 38) offset is incorrect, thus causing extremely bad data. As a result, the unadjusted GRAPE data are plotted as a solid line, with "diameter-adjusted" data presented as a dotted line. The obvious errors were then corrected by hand. This presentation allows investigators to manipulate the data. Investigators interested in the density of a specific layer or rock piece should check the sample diameter from the core photographs and make the appropriate diameter corrections, as discussed in Boyce (1976):

Boyce, R.E., 1976. Definitions and laboratory techniques of compressional sound velocity parameters and wet-water content, wet-bulk density, and porosity parameters by gravimetric and gamma ray attenuation techniques. In Schlanger, S.O., Jackson, E.D., et al., Init. Repts. DSDP, 33: Washington (U.S. Govt. Printing Office)

NOTE: The upper scale is GRAPE wet-bulk density $\left(1.0\right.$ to $\left.3.0 \mathrm{~g} / \mathrm{cm}^{3}\right)$; solid lines (are GRAPE analog data assuming a $6.61 \mathrm{~cm}$ core diameter: dotted lines $(\ldots .$.$) are$ GRAPE analog data adjusted for actual core diameter; circled dots ( $(\overline{)})$ are wet-bulk
density calculated from 2 -minute counts on a stationary sample; the porosity nomogran density calculated from 2-minute counts on a stationary sample: the porosity nom extrapolating horizontally. 


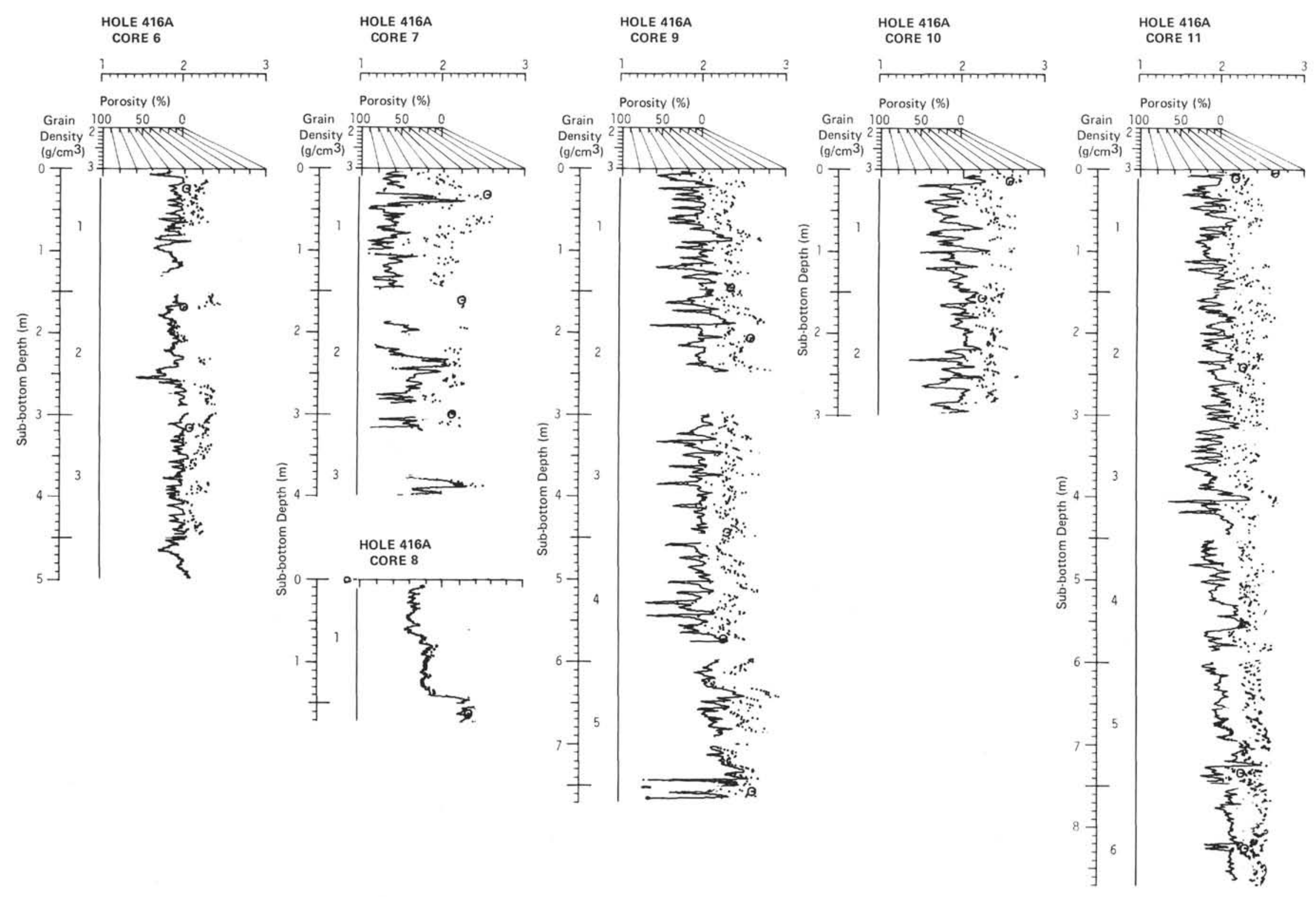




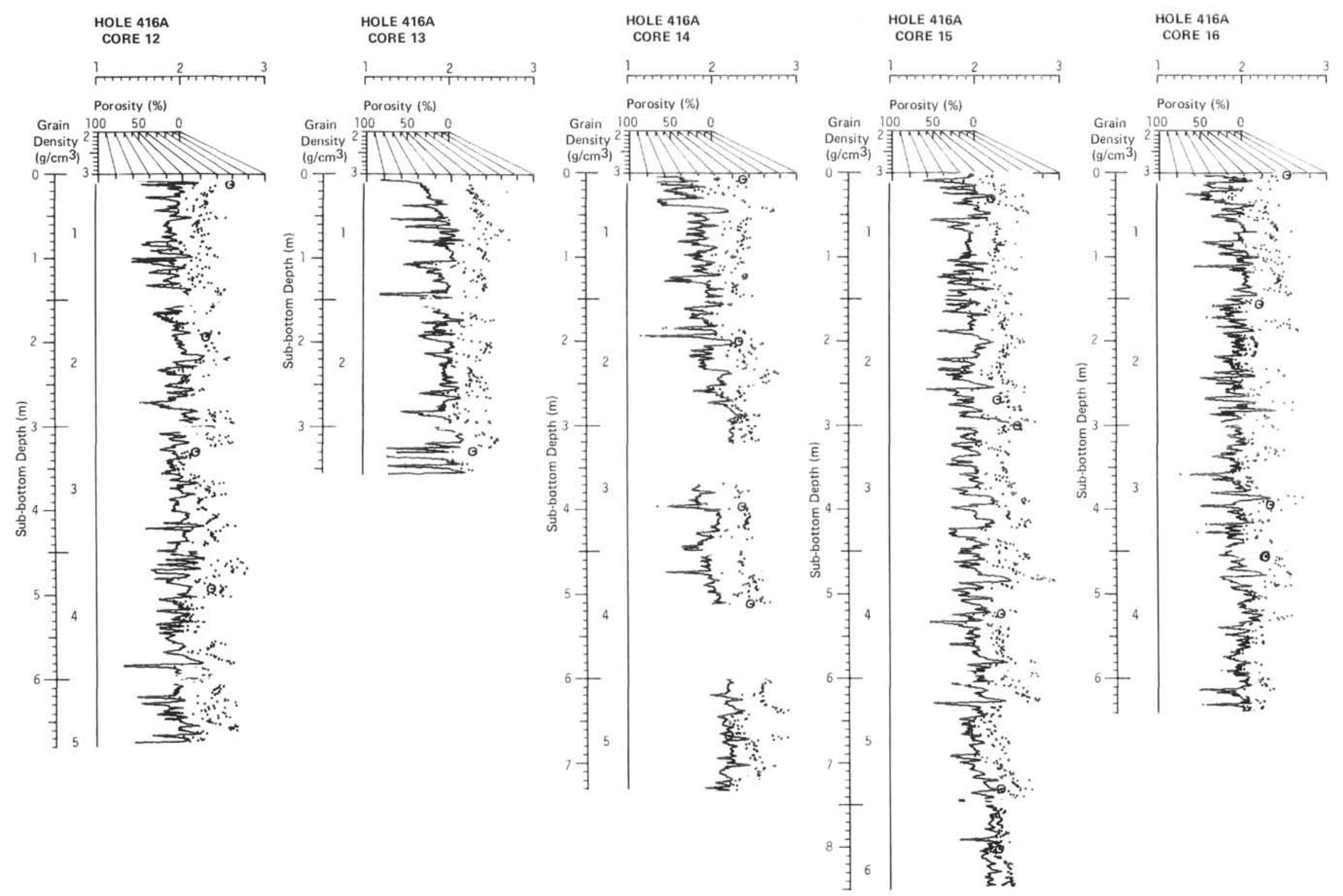




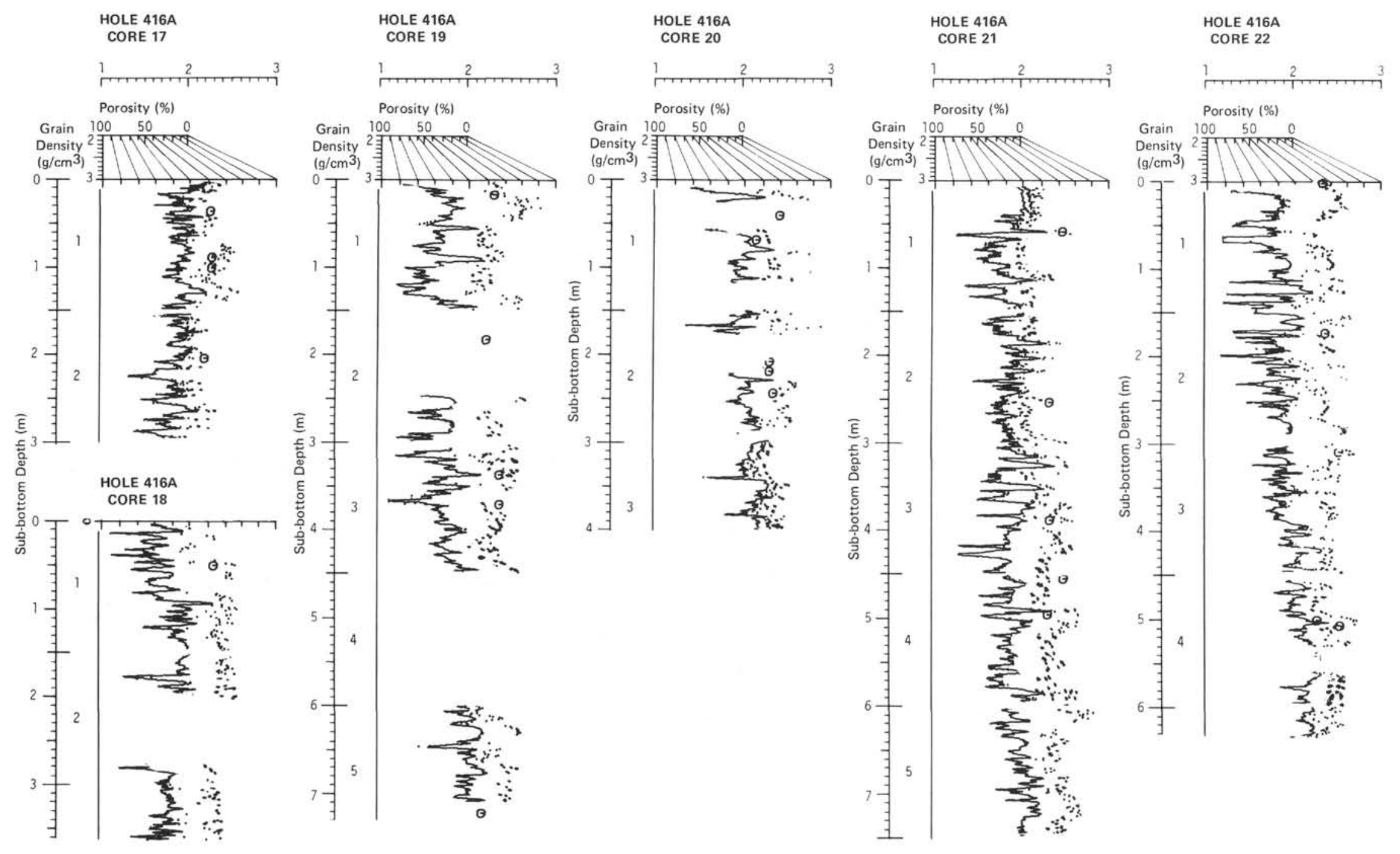




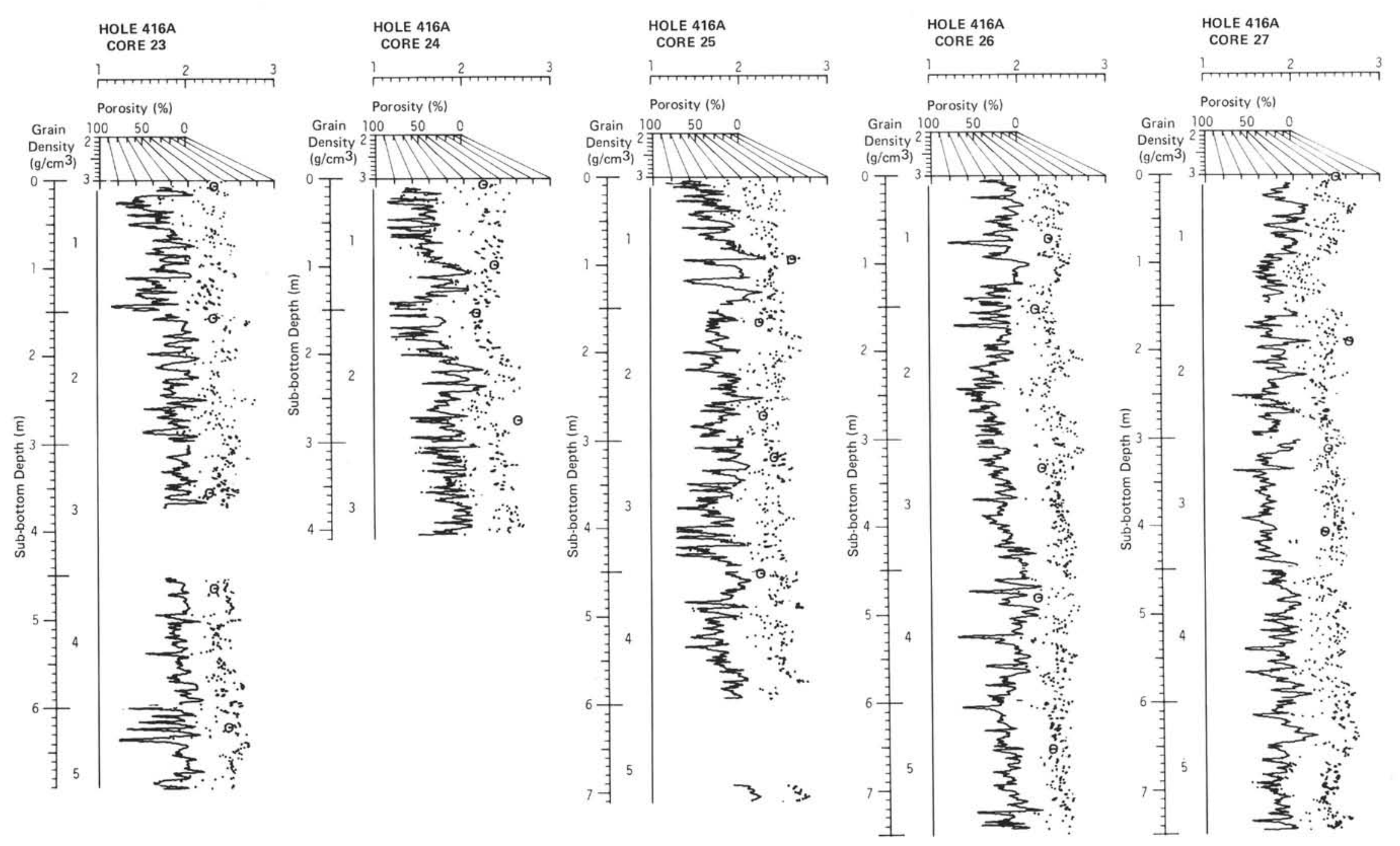




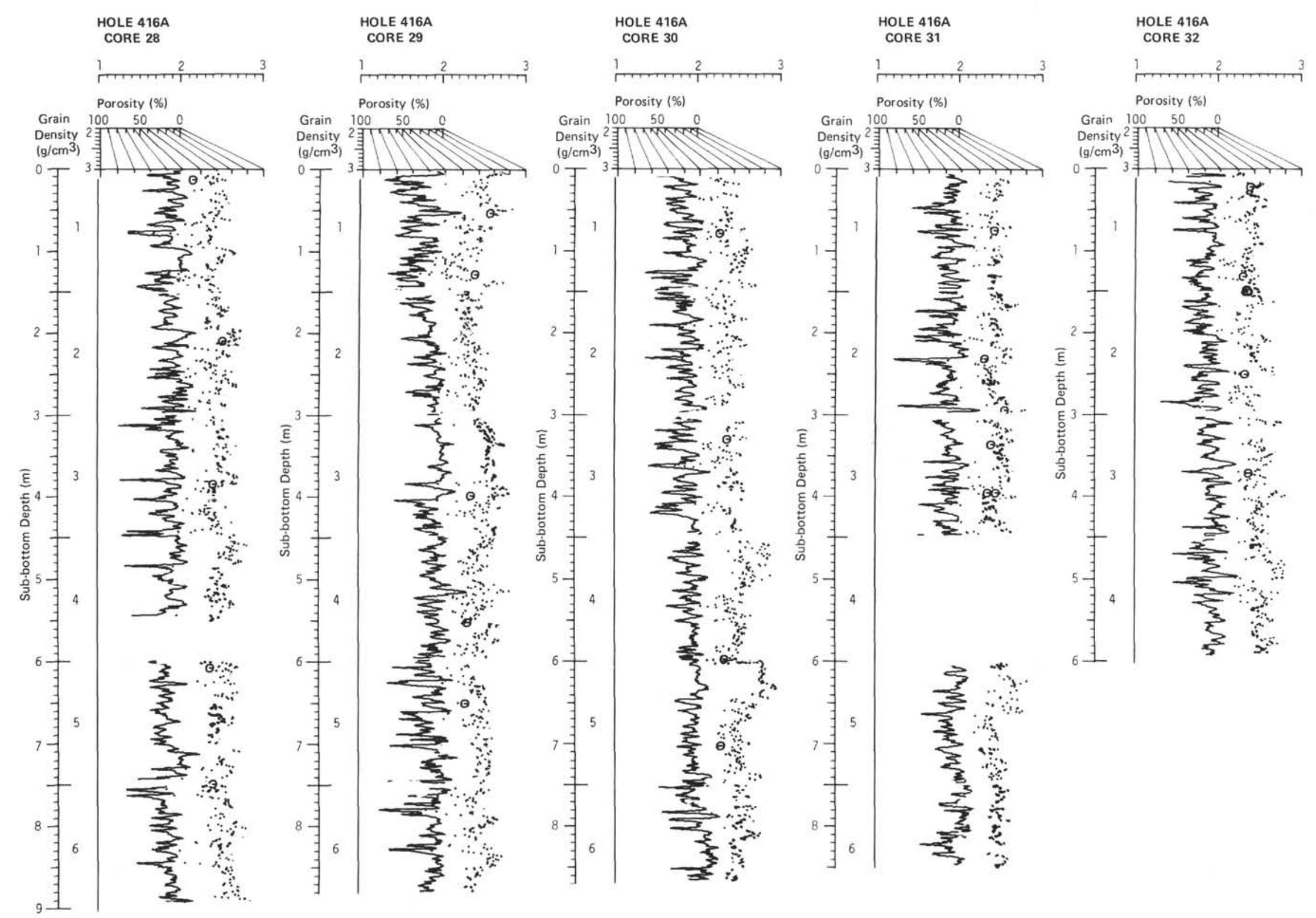




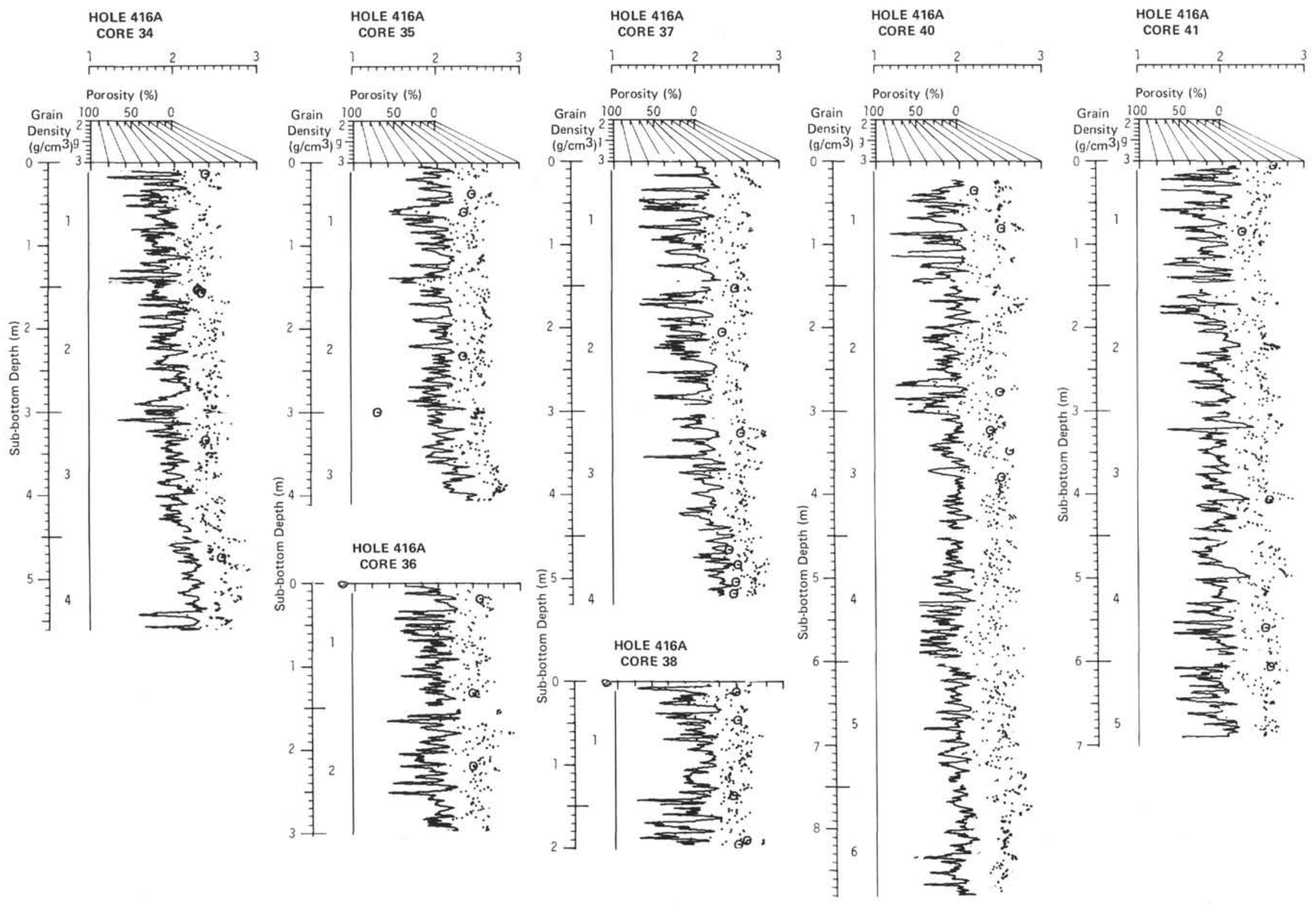




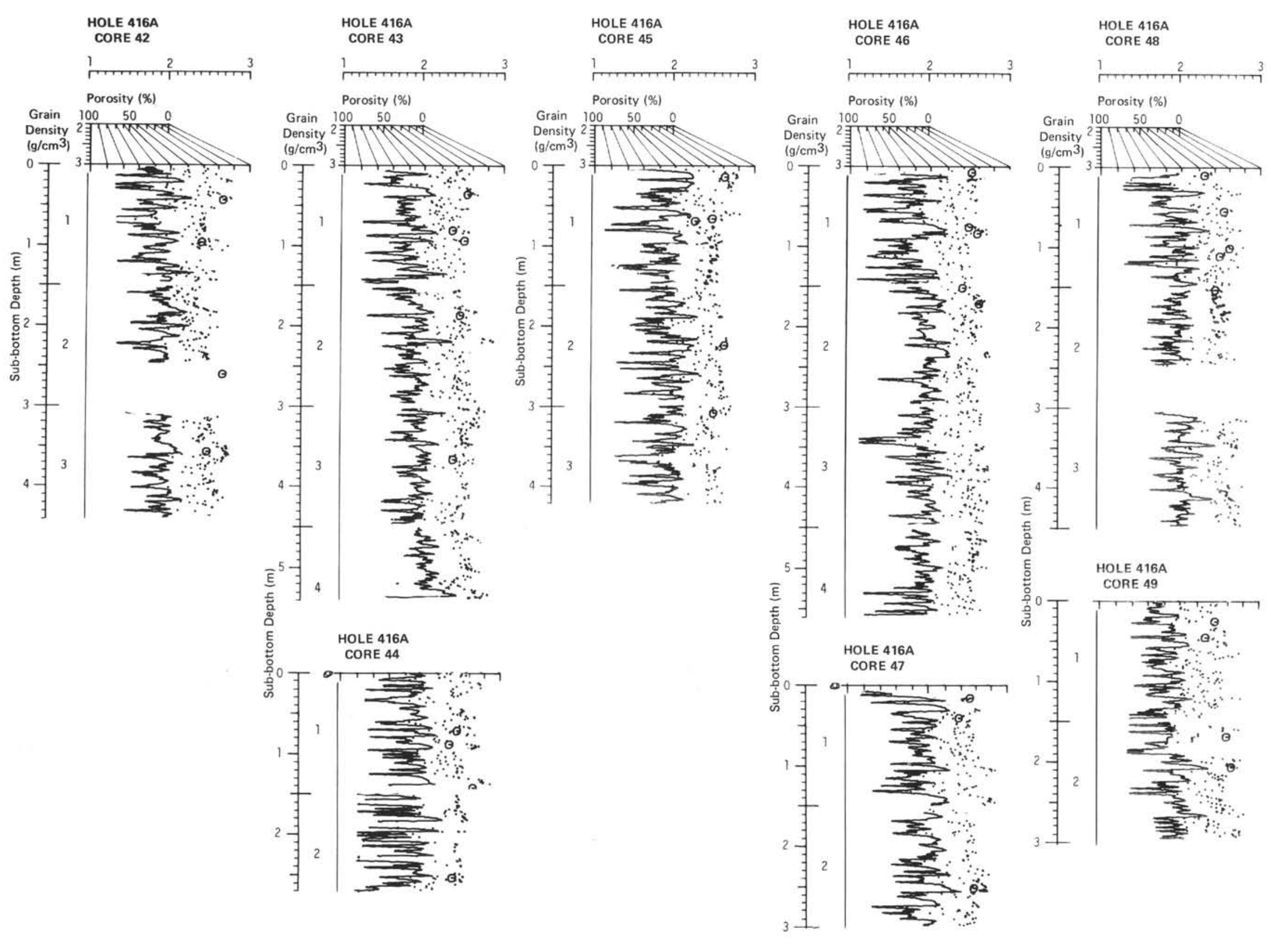




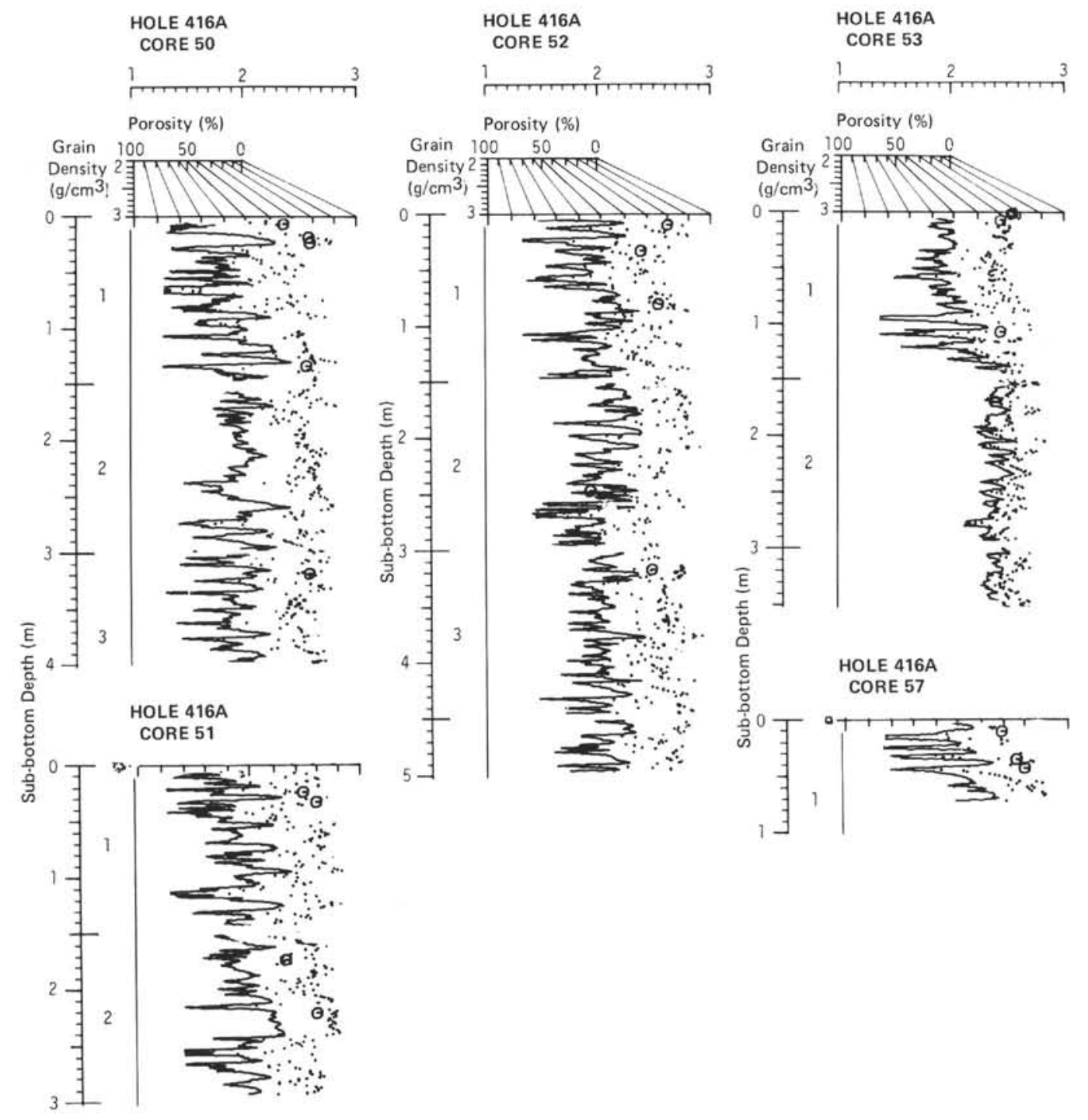





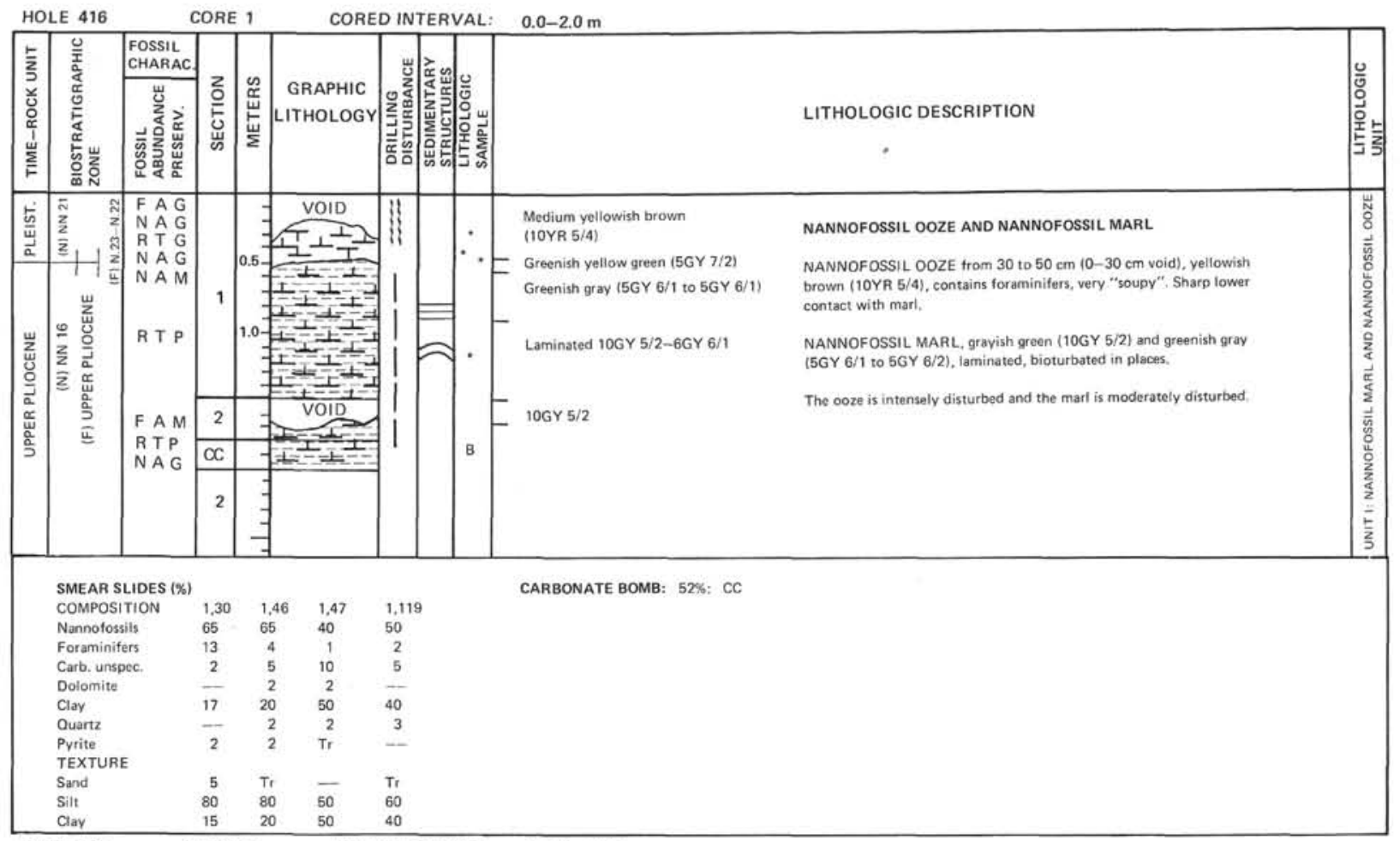

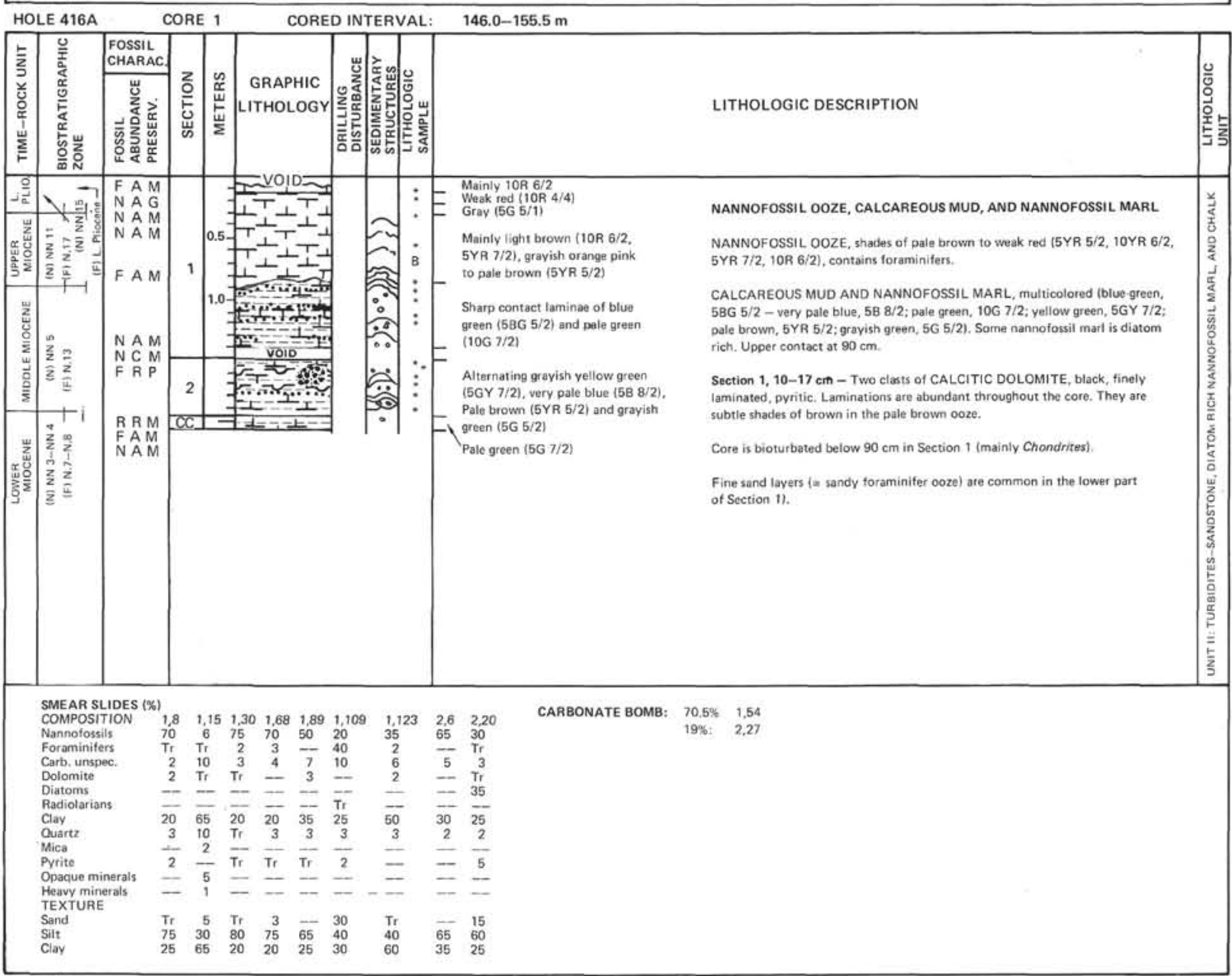

1 Information on core description sheets represents field notes taken aboard ship under time pressure. Some of this information has been refined in accord with postcruise findings, but production schedules prohibit definitive correlation of these sheets with subsequent findings. Thus the reader should be alerted to the occasional ambiguity or discrepancy. 

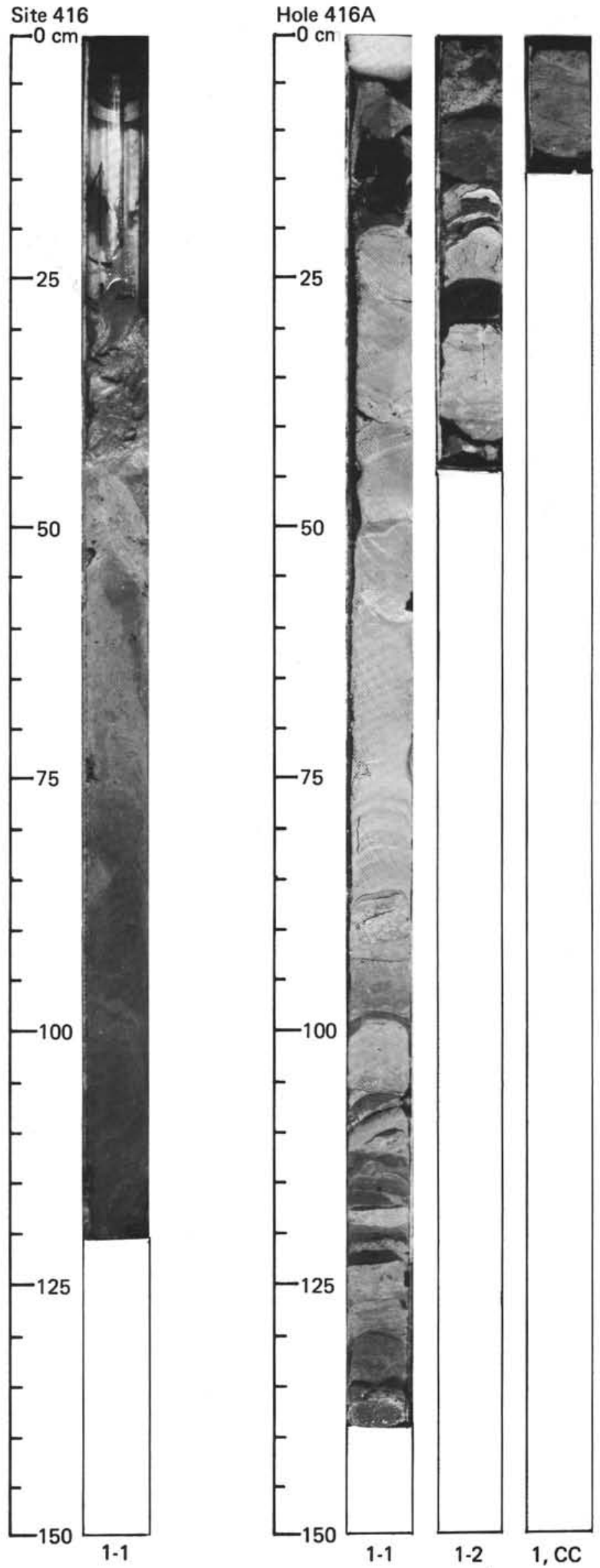


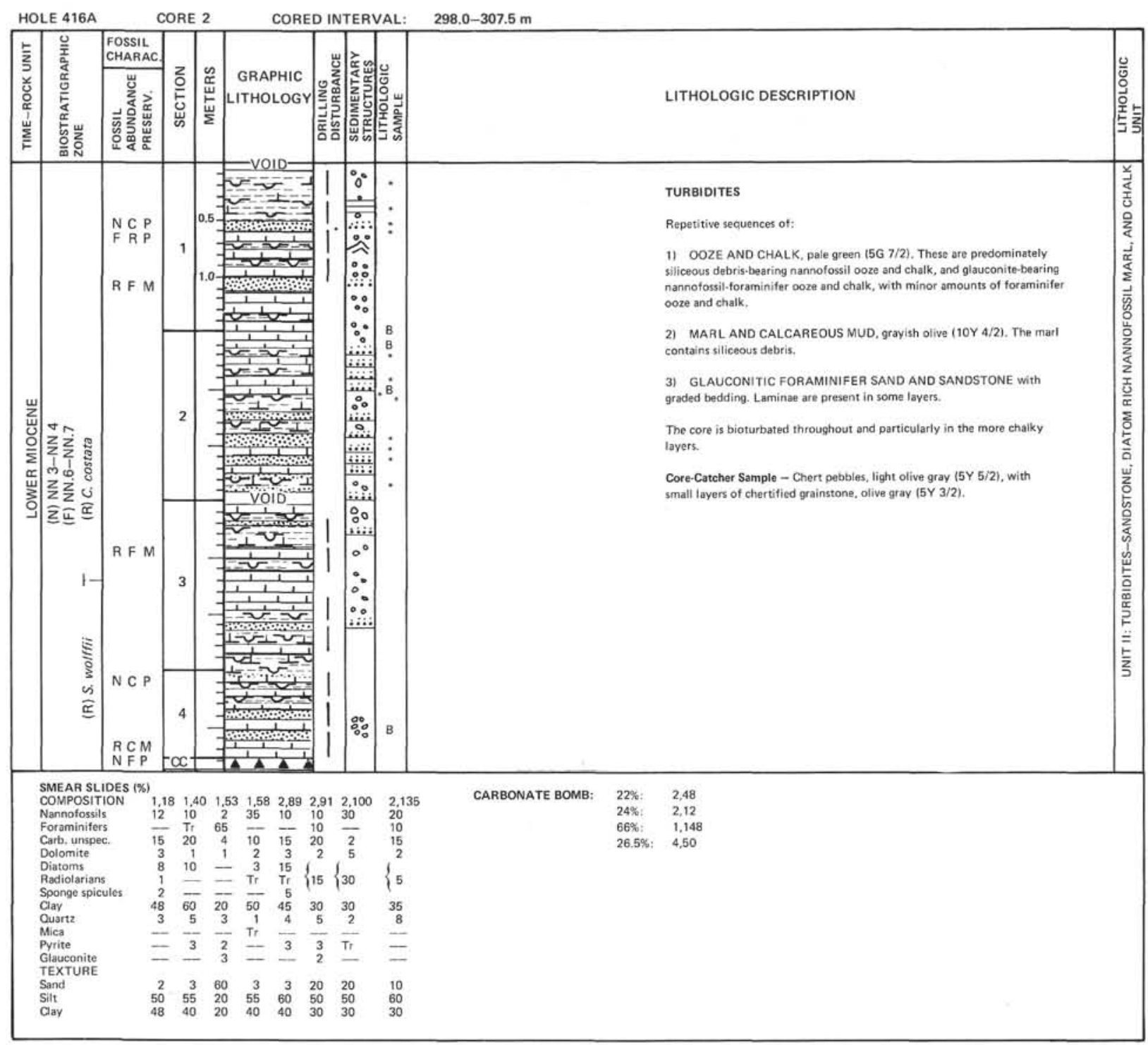




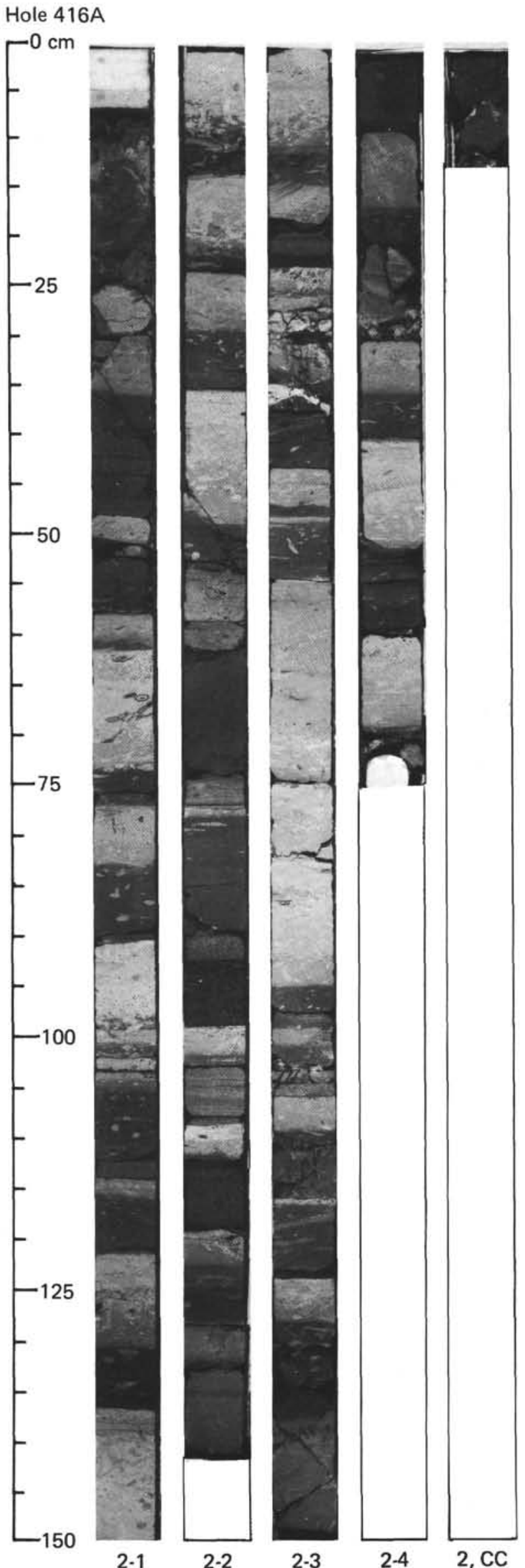




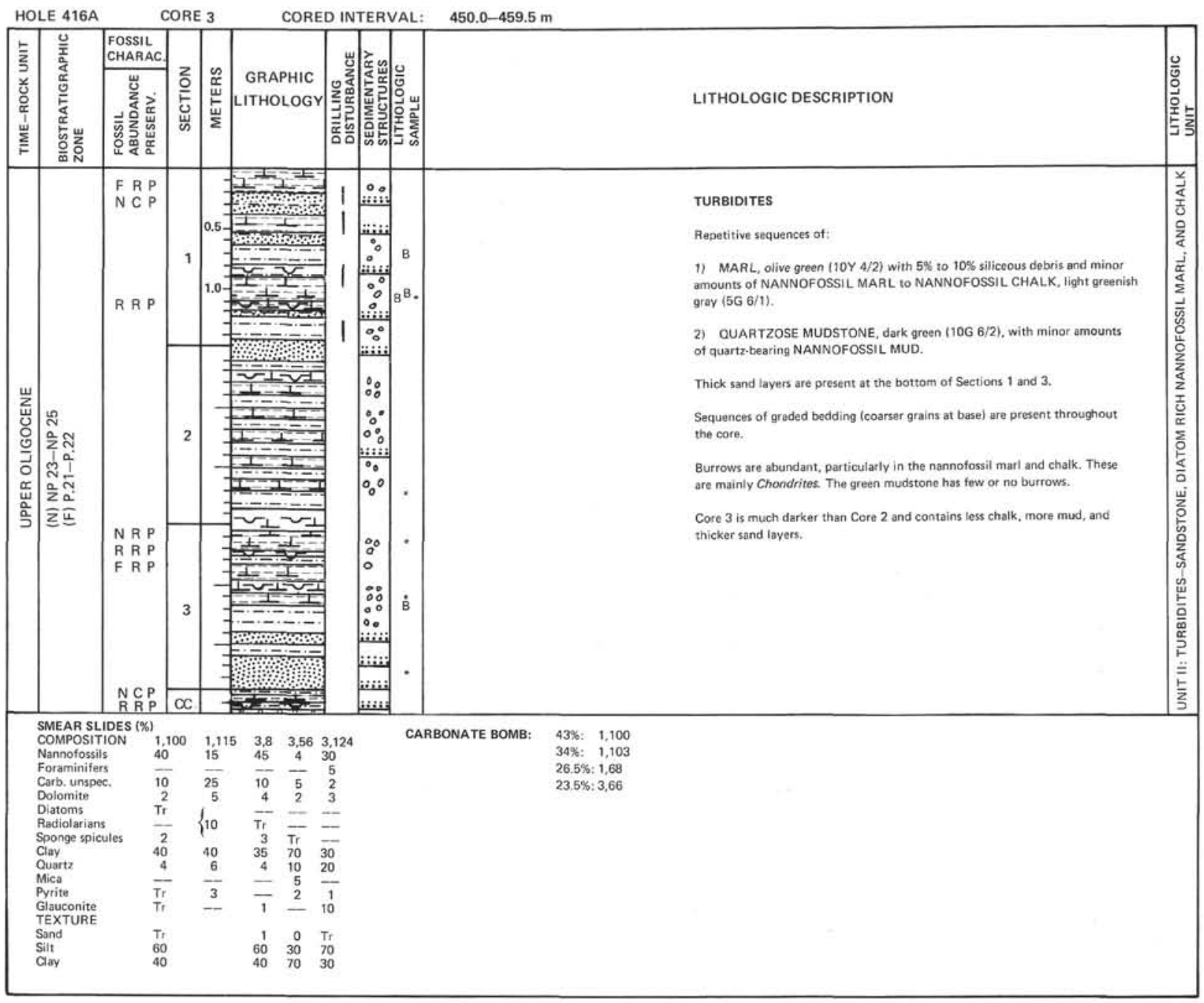


Hole 416A

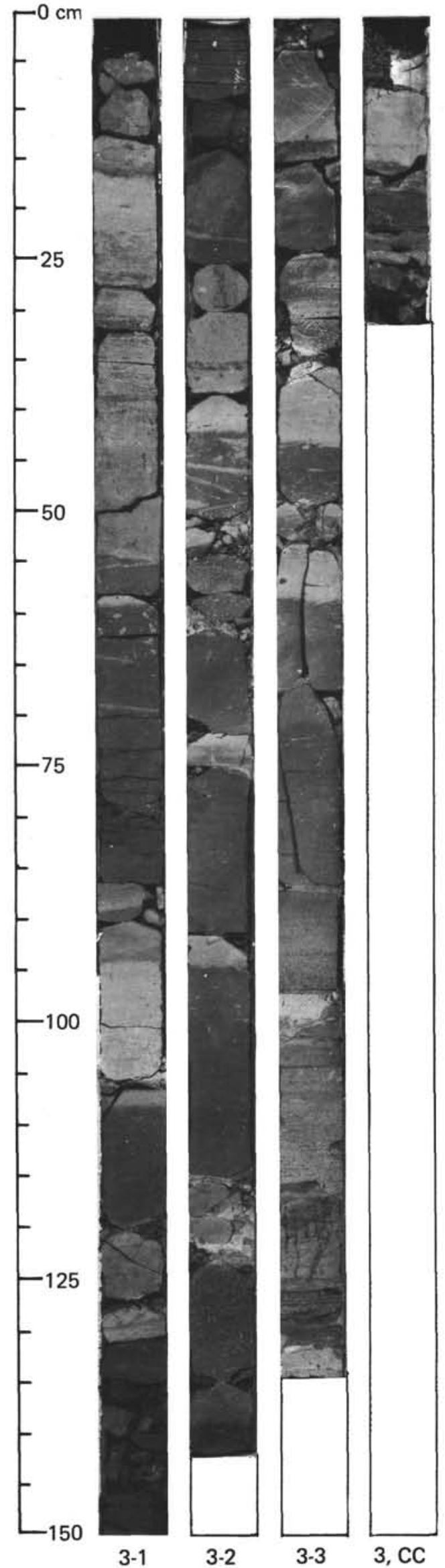




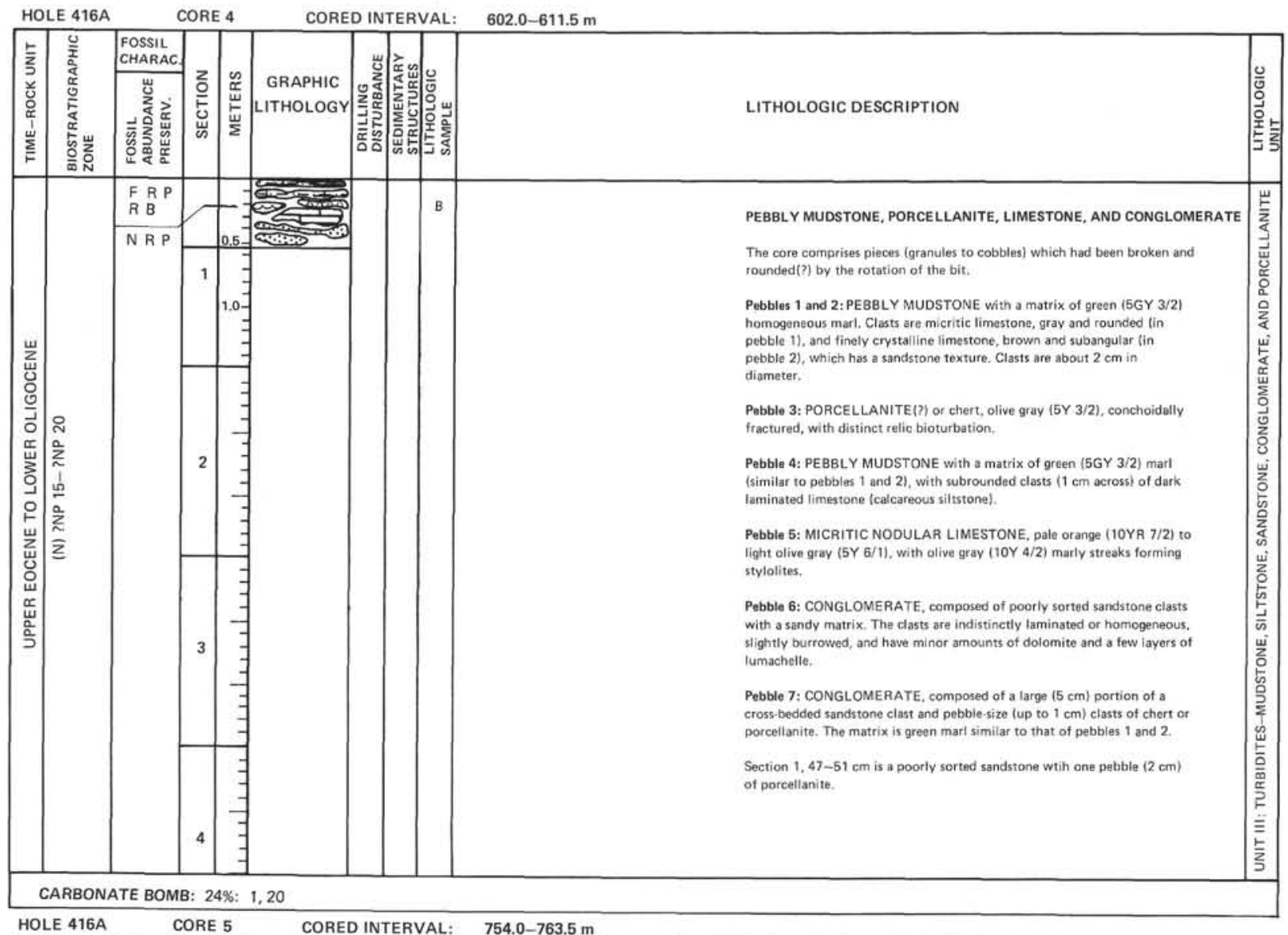

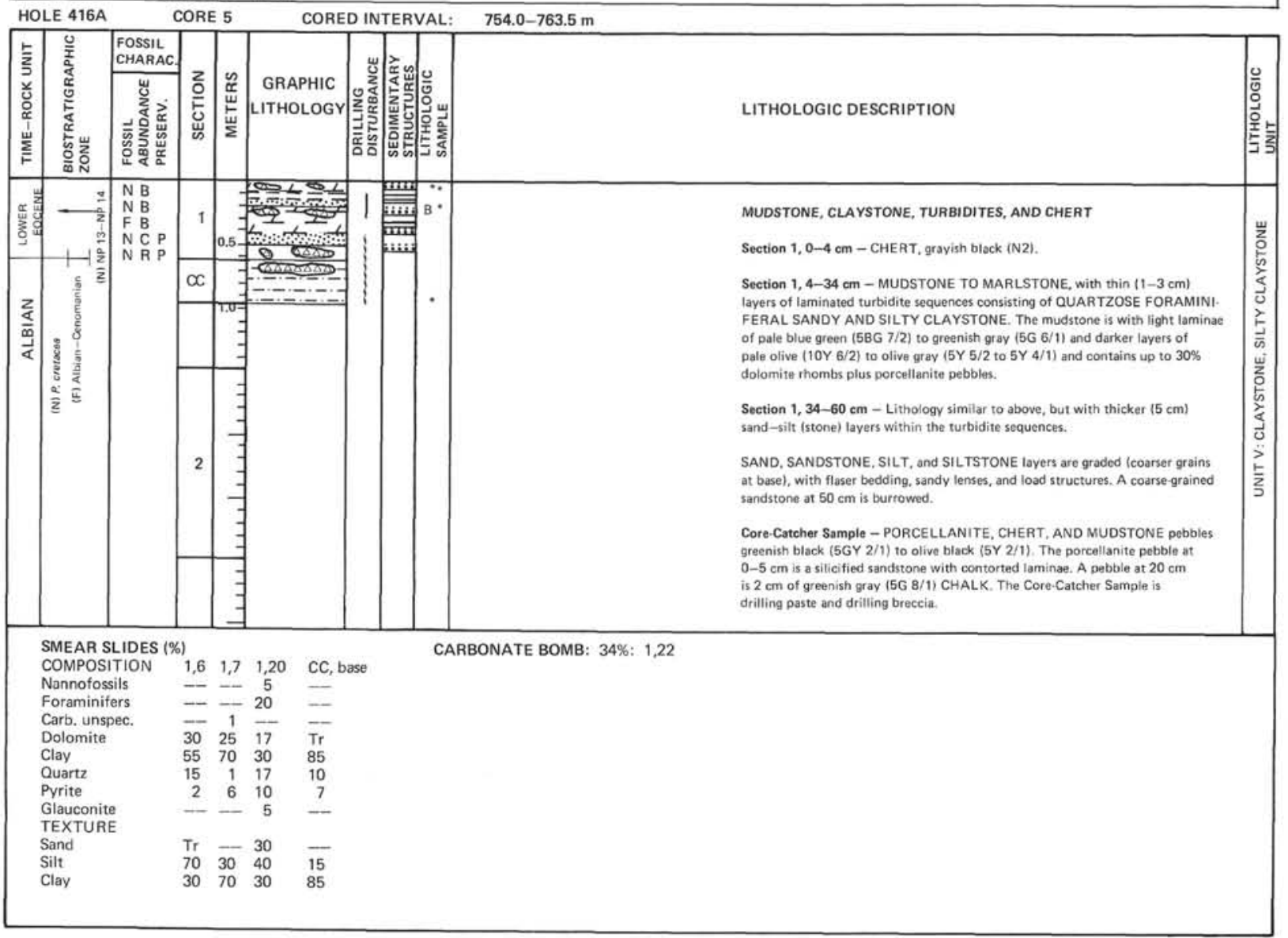


Hole 416A

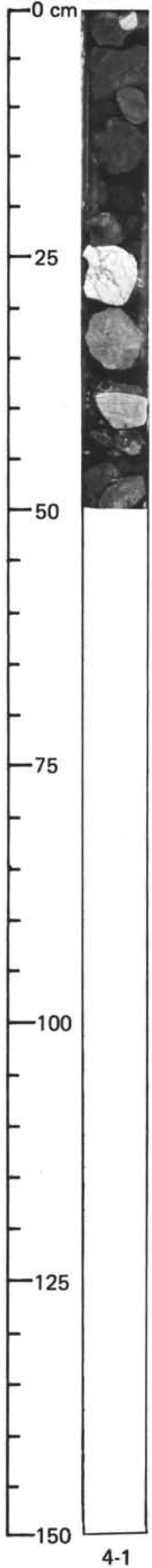

Hole 416A

$-0 \mathrm{~cm}$

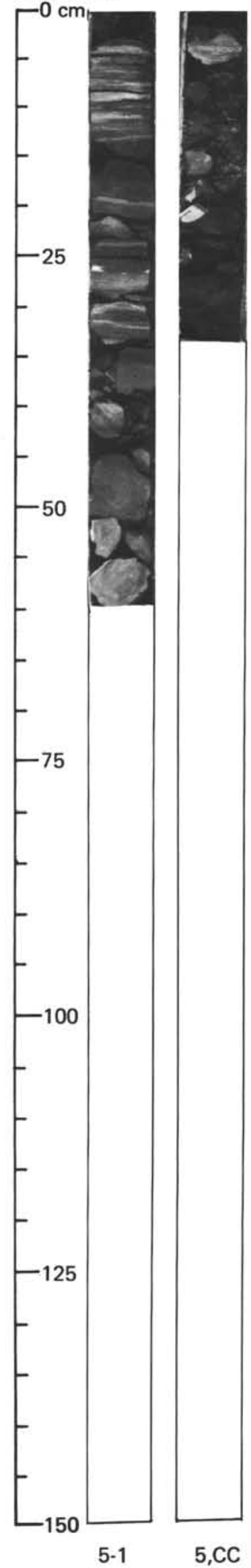




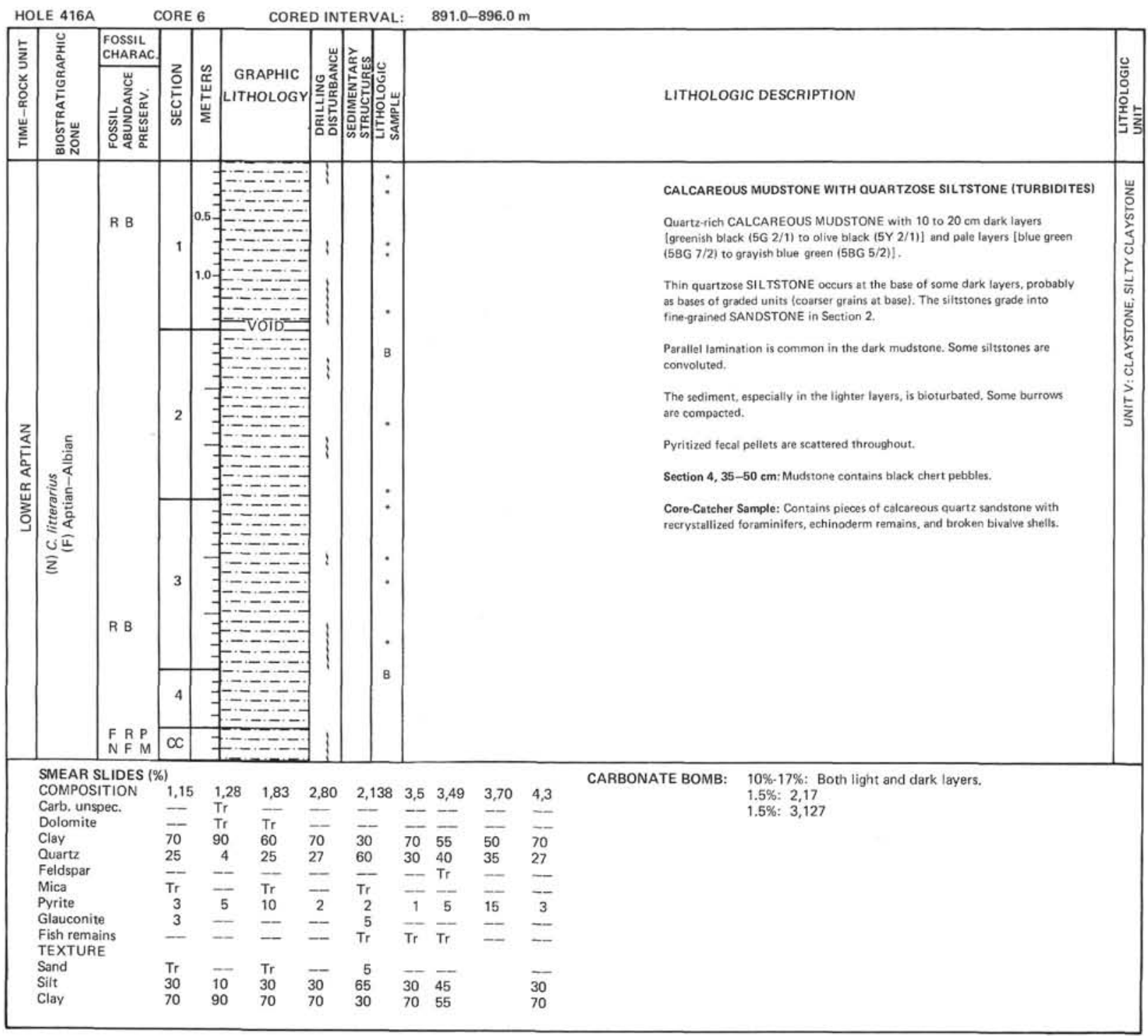




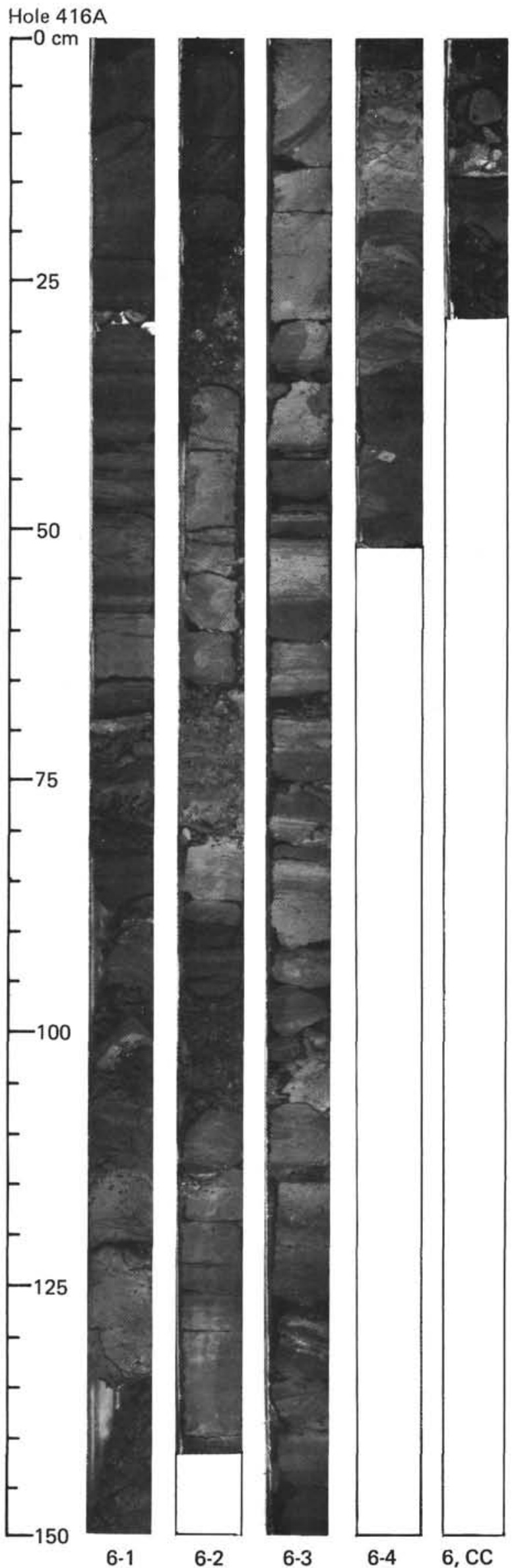




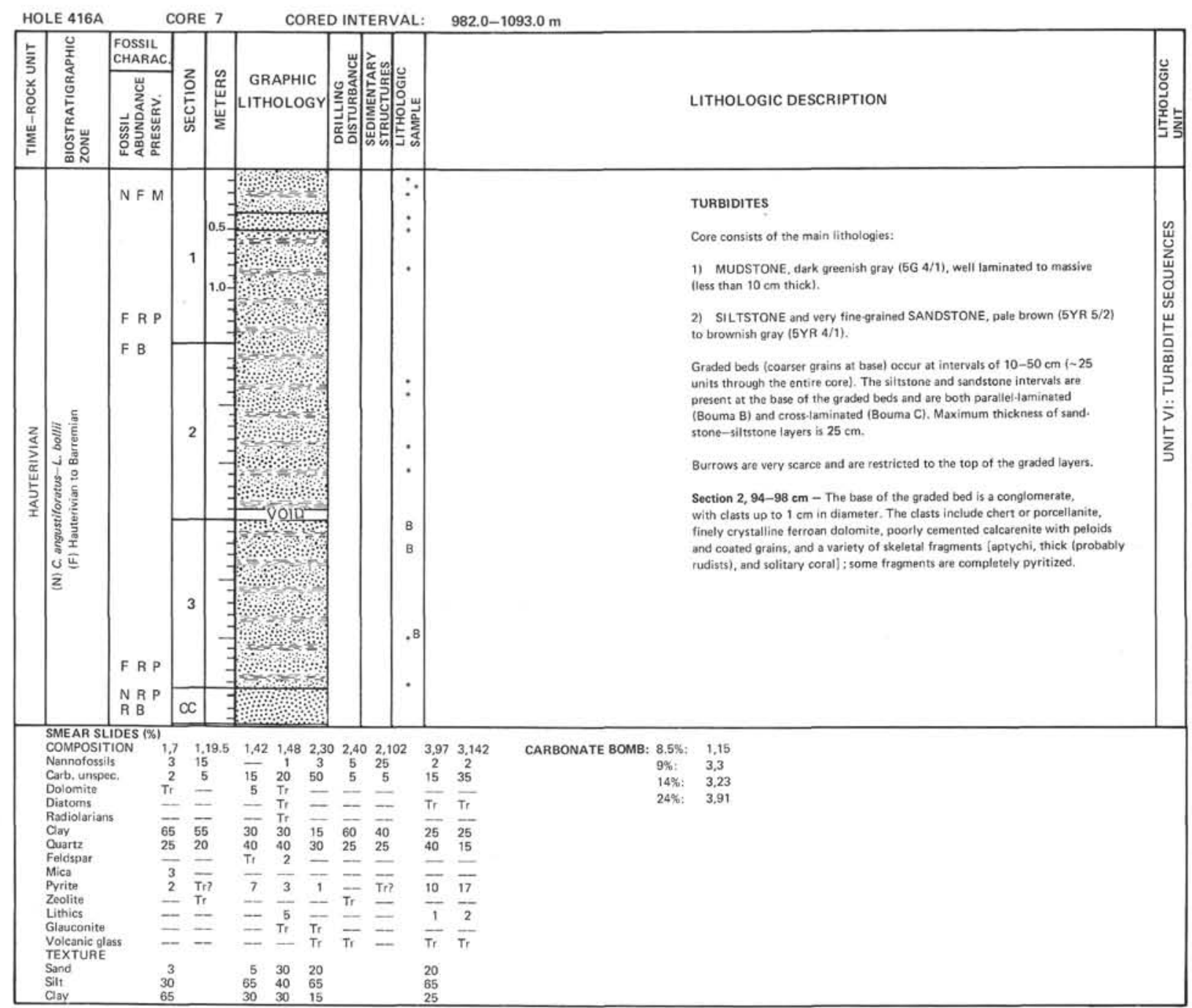


Hole 416A

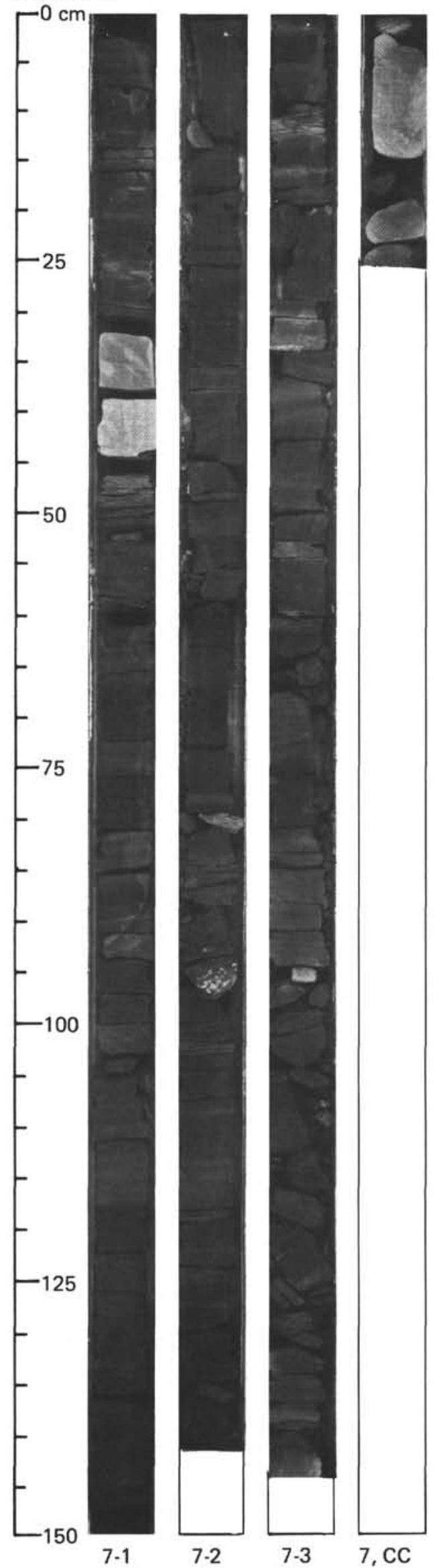


HOLE 416A CORE 8 CORED INTERVAL: 1093.0-1118.0 m

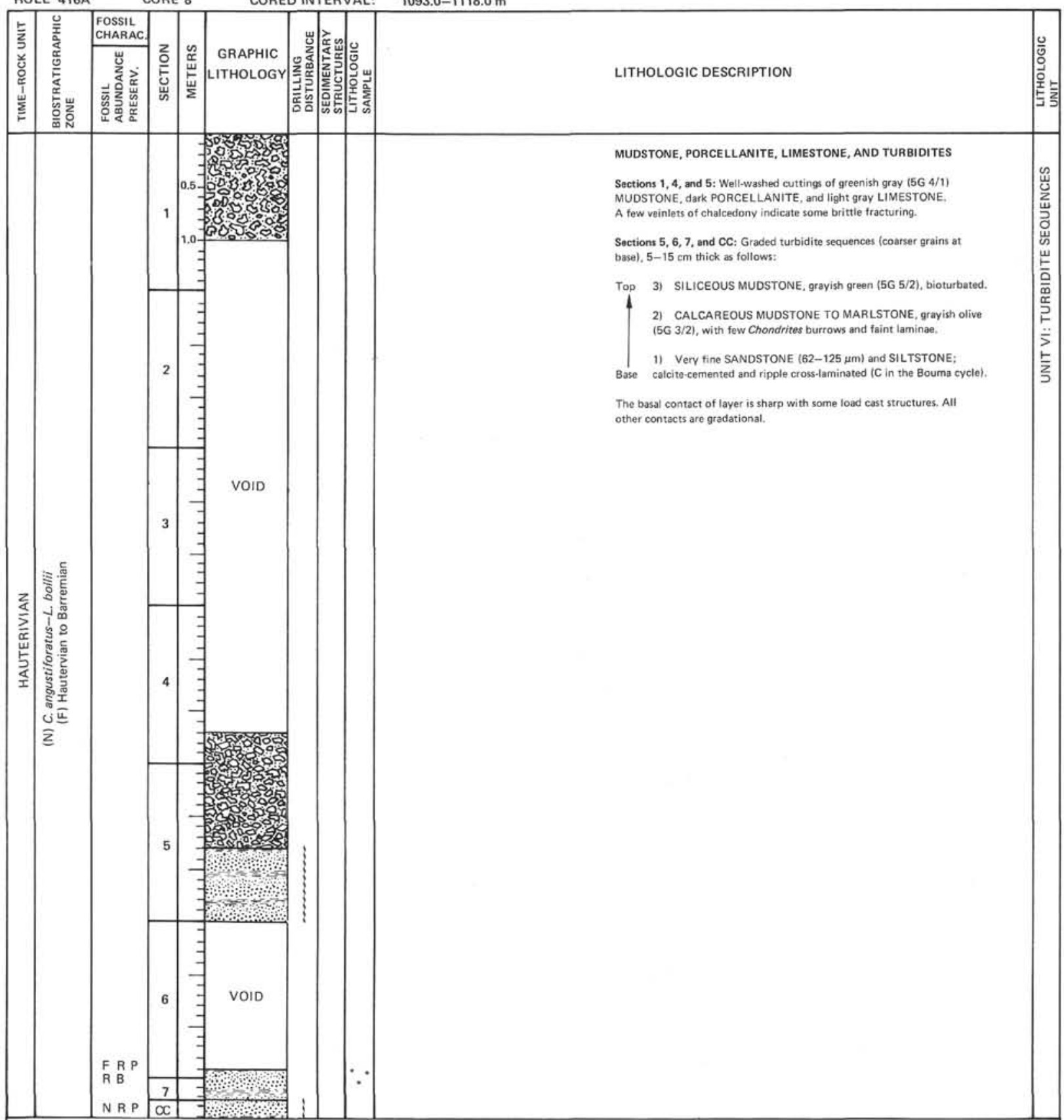

SMEAR SLIDES $(\%)$

$\begin{array}{llcc}\text { COMPOSITION } & 6,145 & 6,147 & 7,2 \\ \text { Nannofossils } & - & 30 & 3 \\ \text { Carb. unspec. } & 30 & 2 & 3 \\ \text { Dolomite } & -- & 1 & -- \\ \text { Clay } & 13 & 60 & 50 \\ \text { Quartz } & 55 & 3 & 40 \\ \text { Mica } & \mathrm{Tr} & - & 2 ? \\ \text { Pyrite } & 1 & 3 & 7 \\ \text { Chert } & 2 & -- & -- \\ \text { TEXTURE } & & & \\ \text { Sand } & 3 & -- & -- \\ \text { Silt } & 80 & 40 & -- \\ \text { Clay } & 15 & 60 & -\end{array}$


Hole 416A

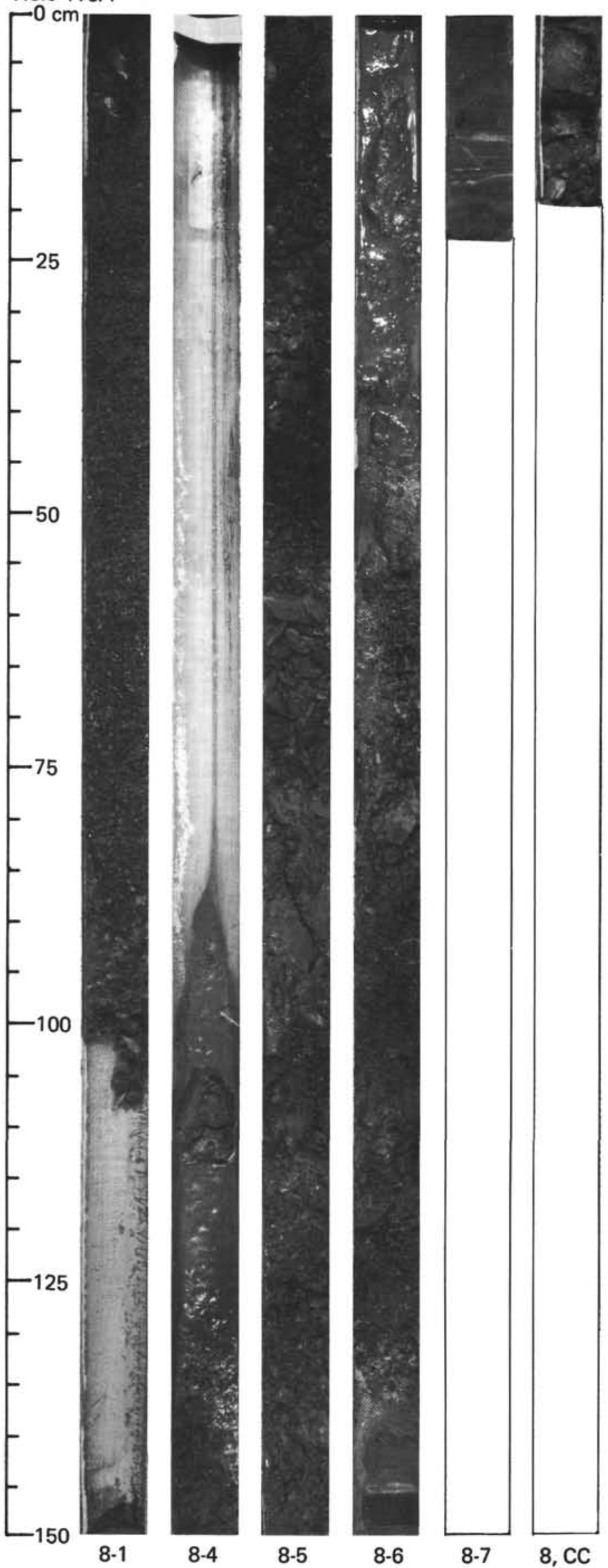




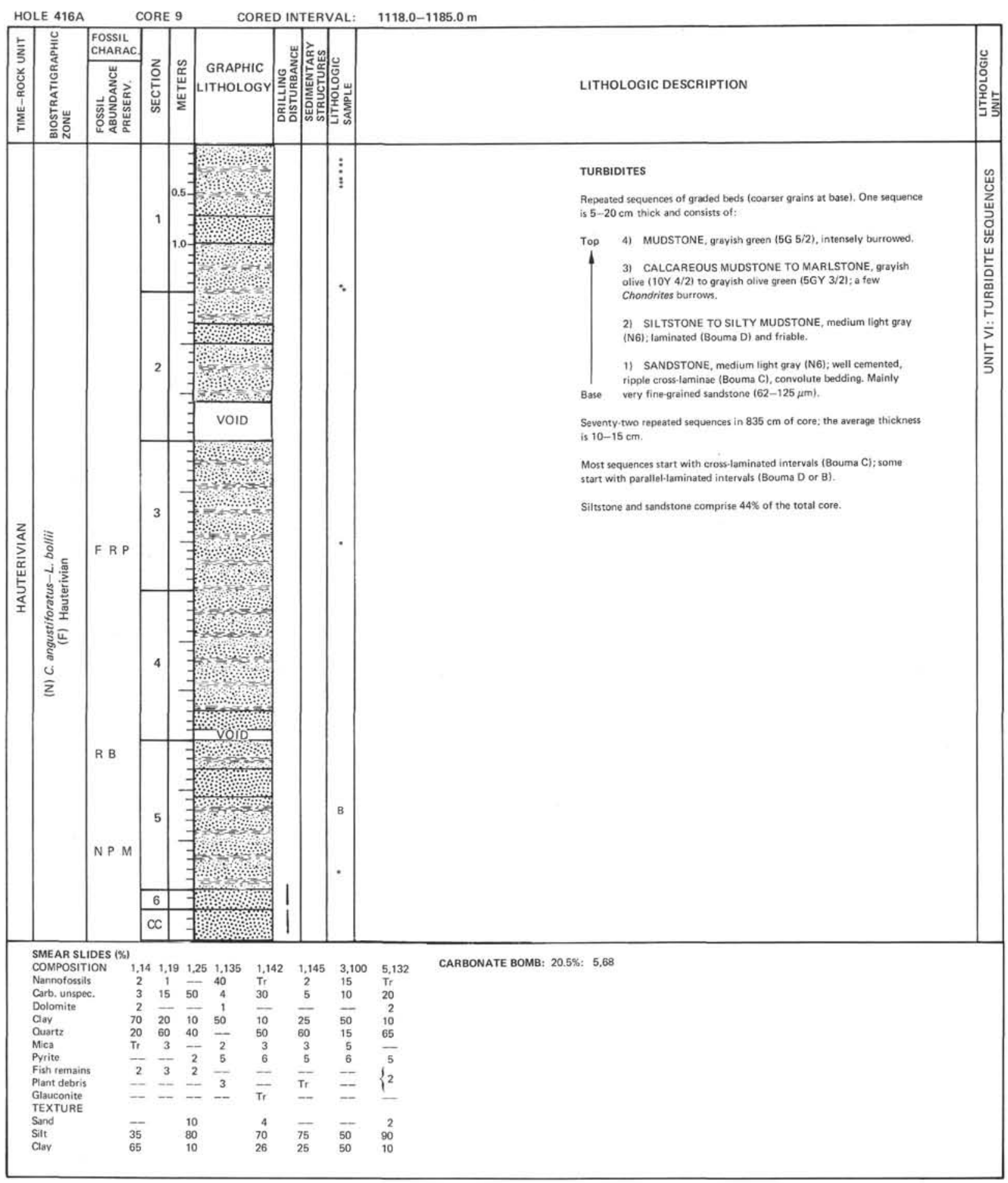


Hole 416A

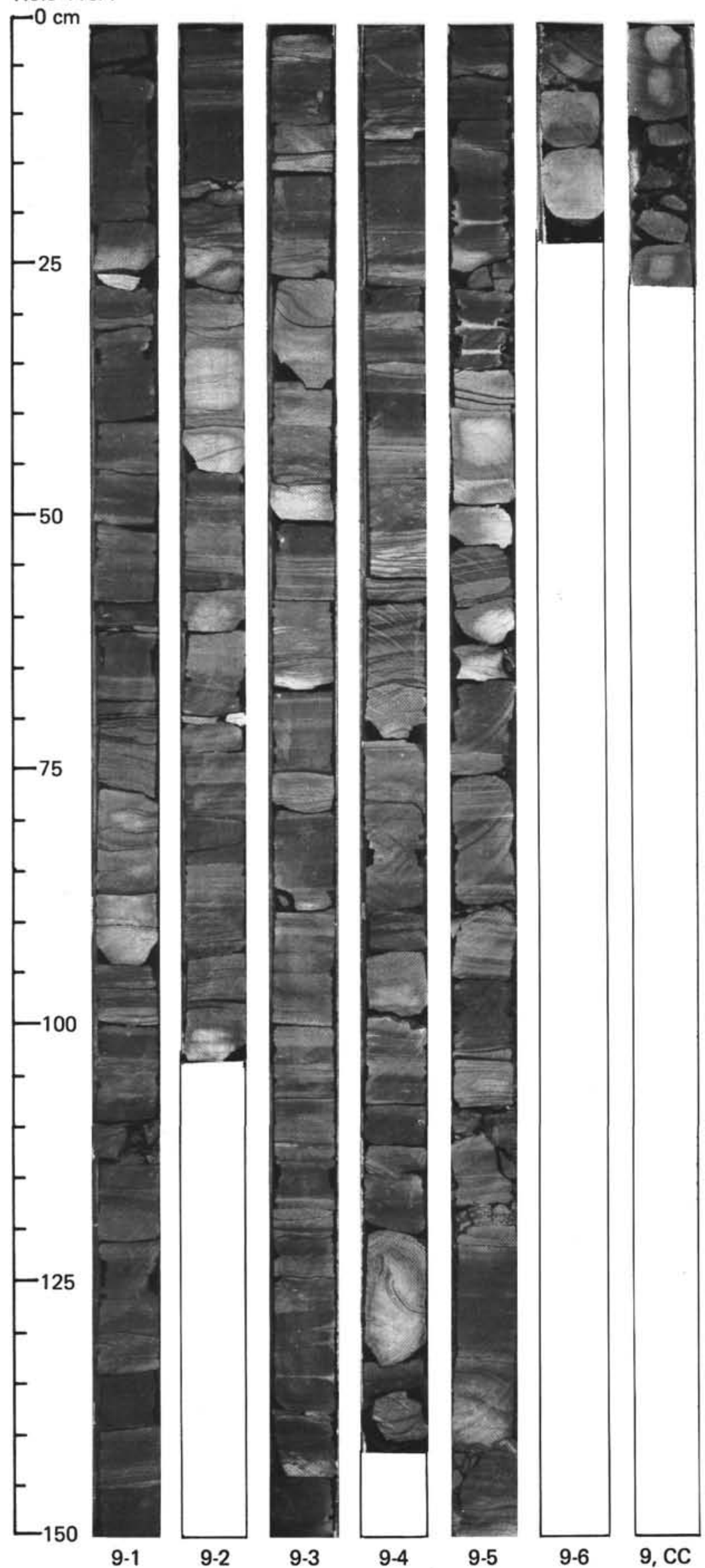




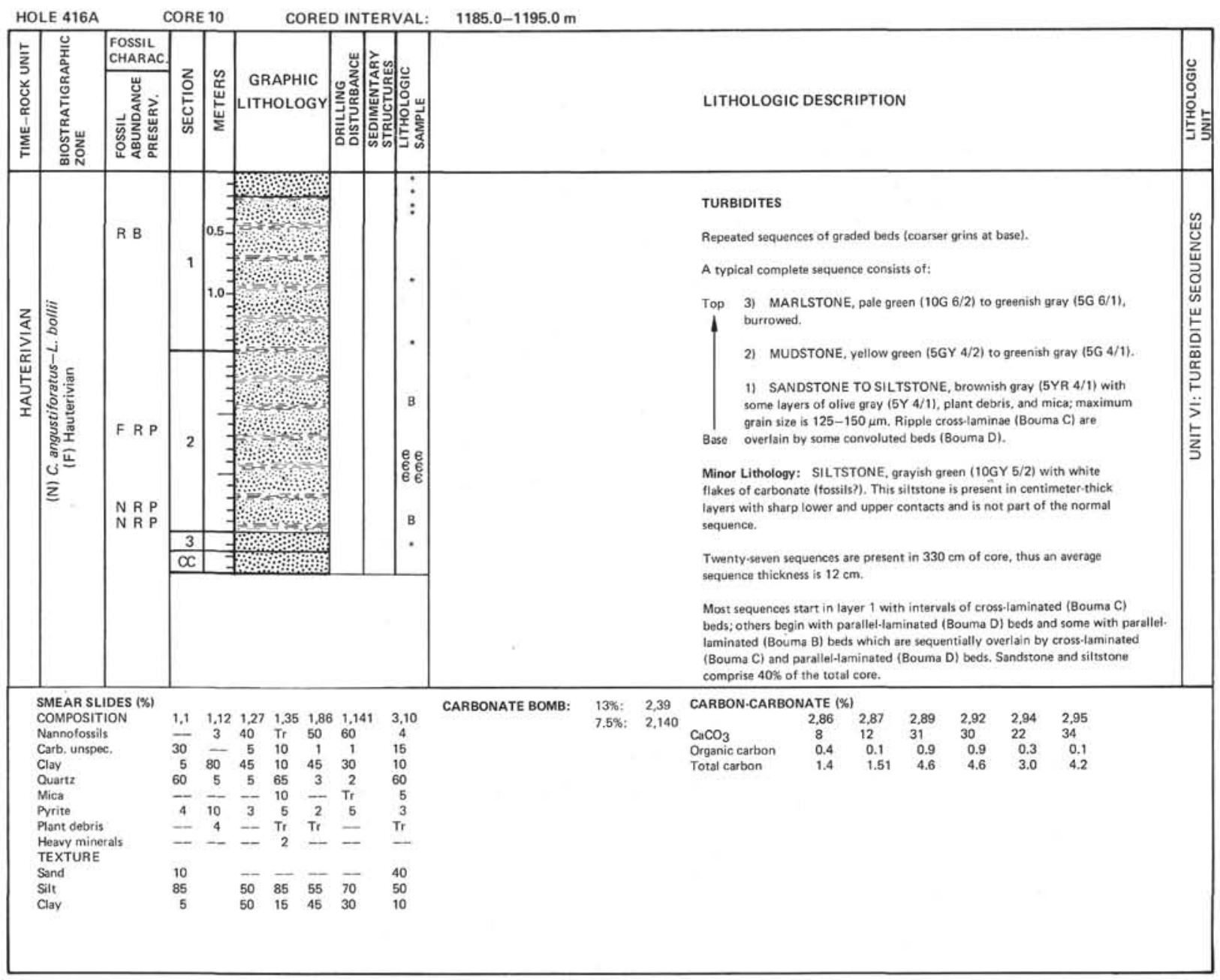


Hole 416A

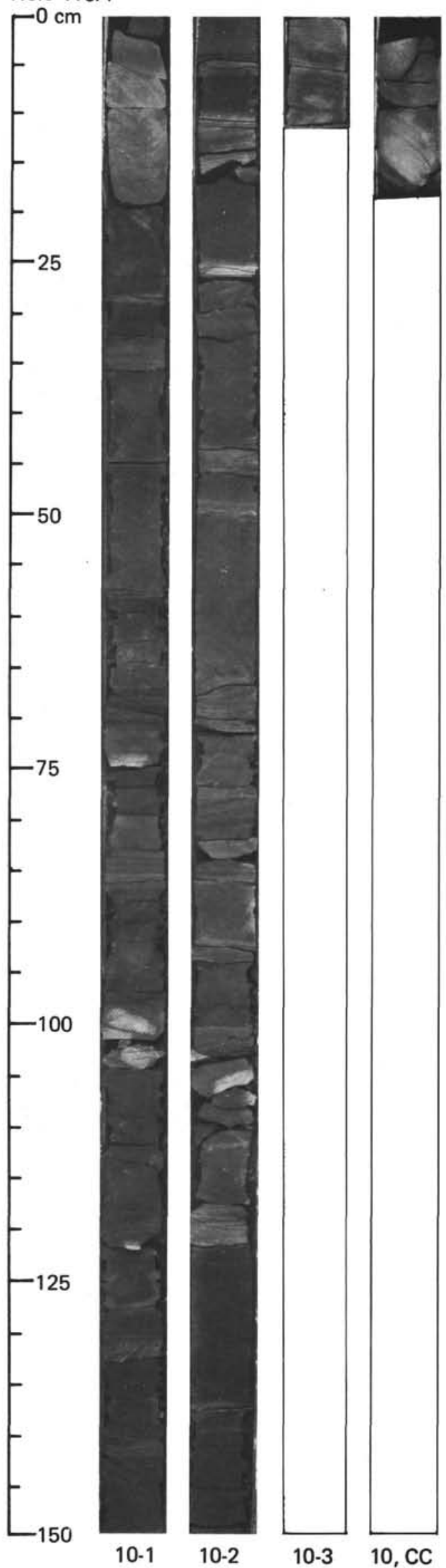




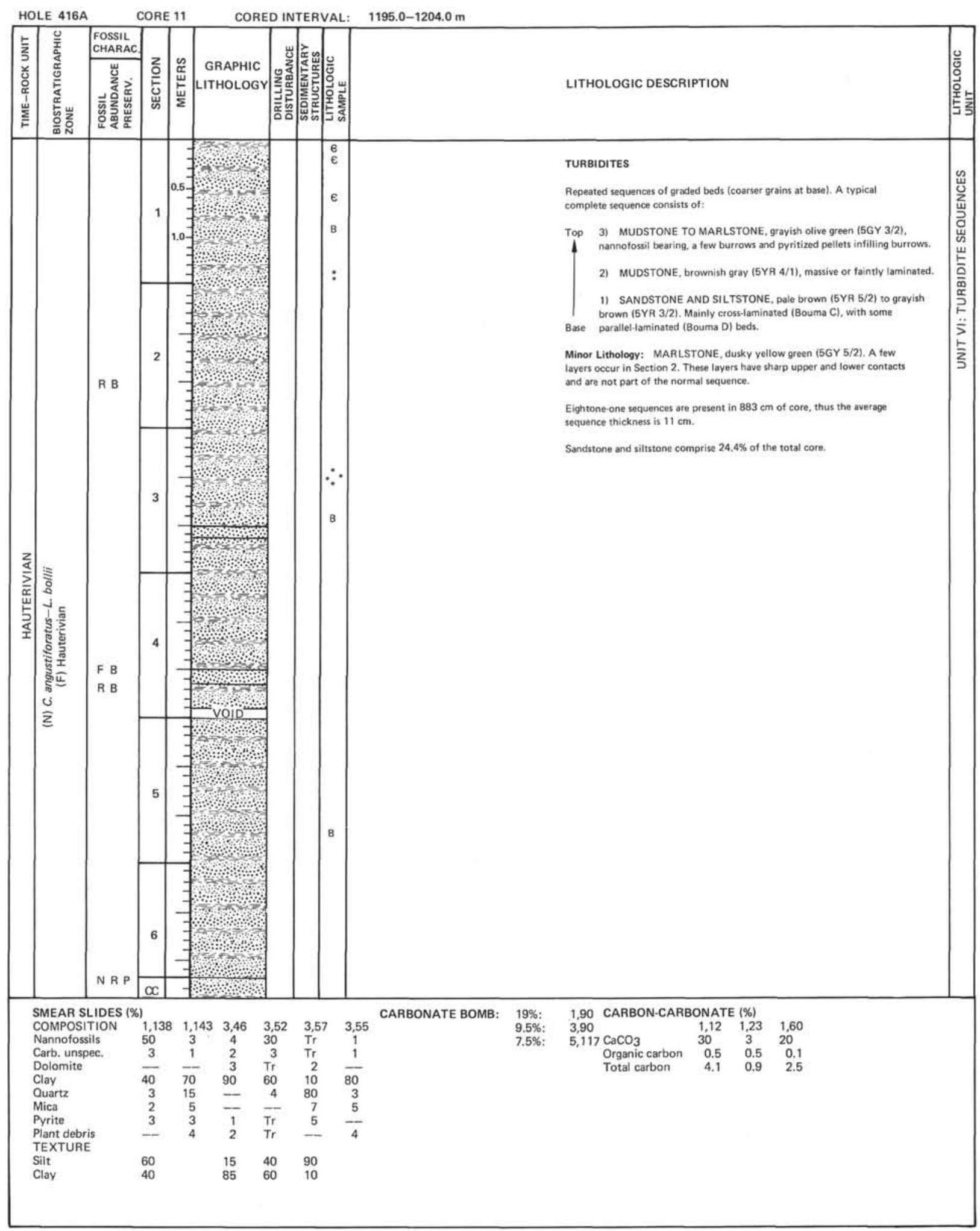


Hole 416A

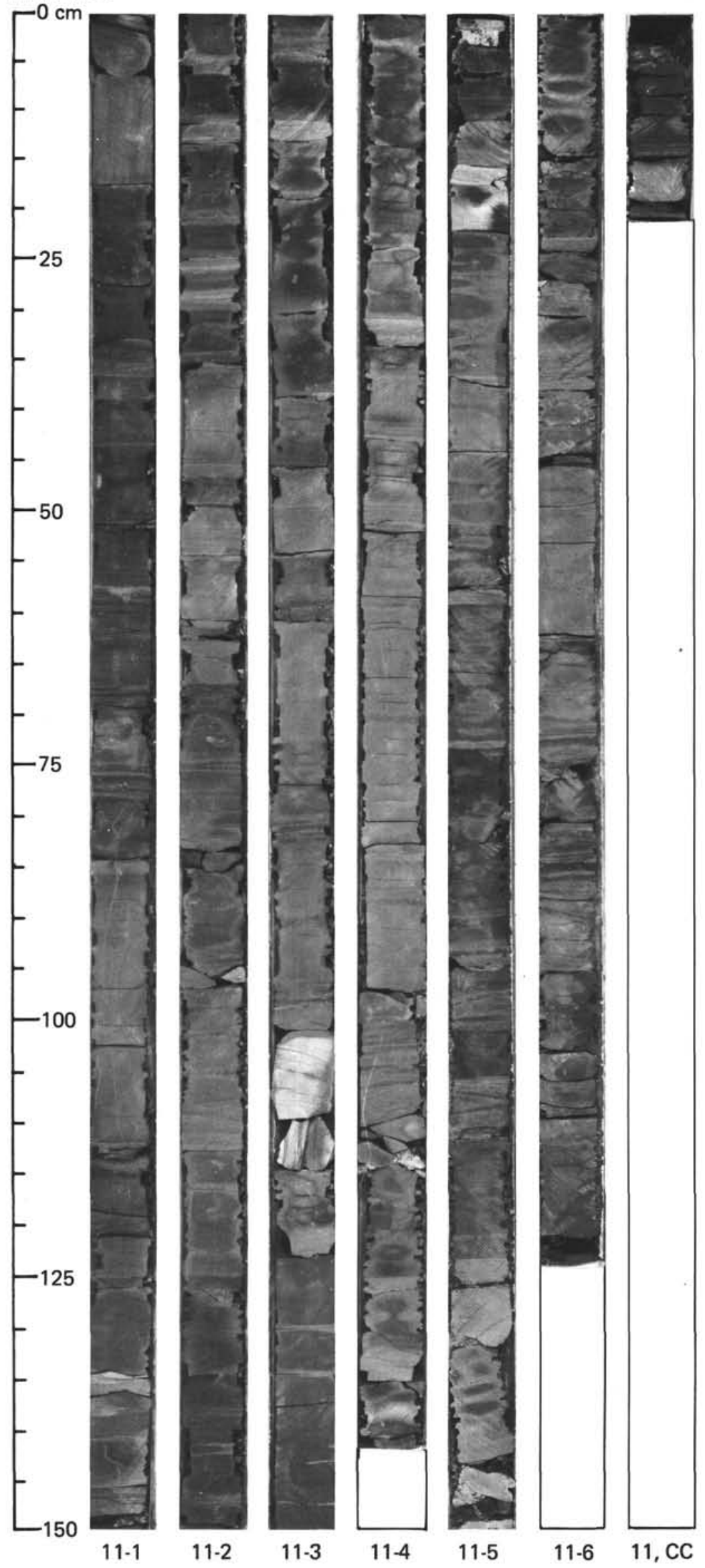




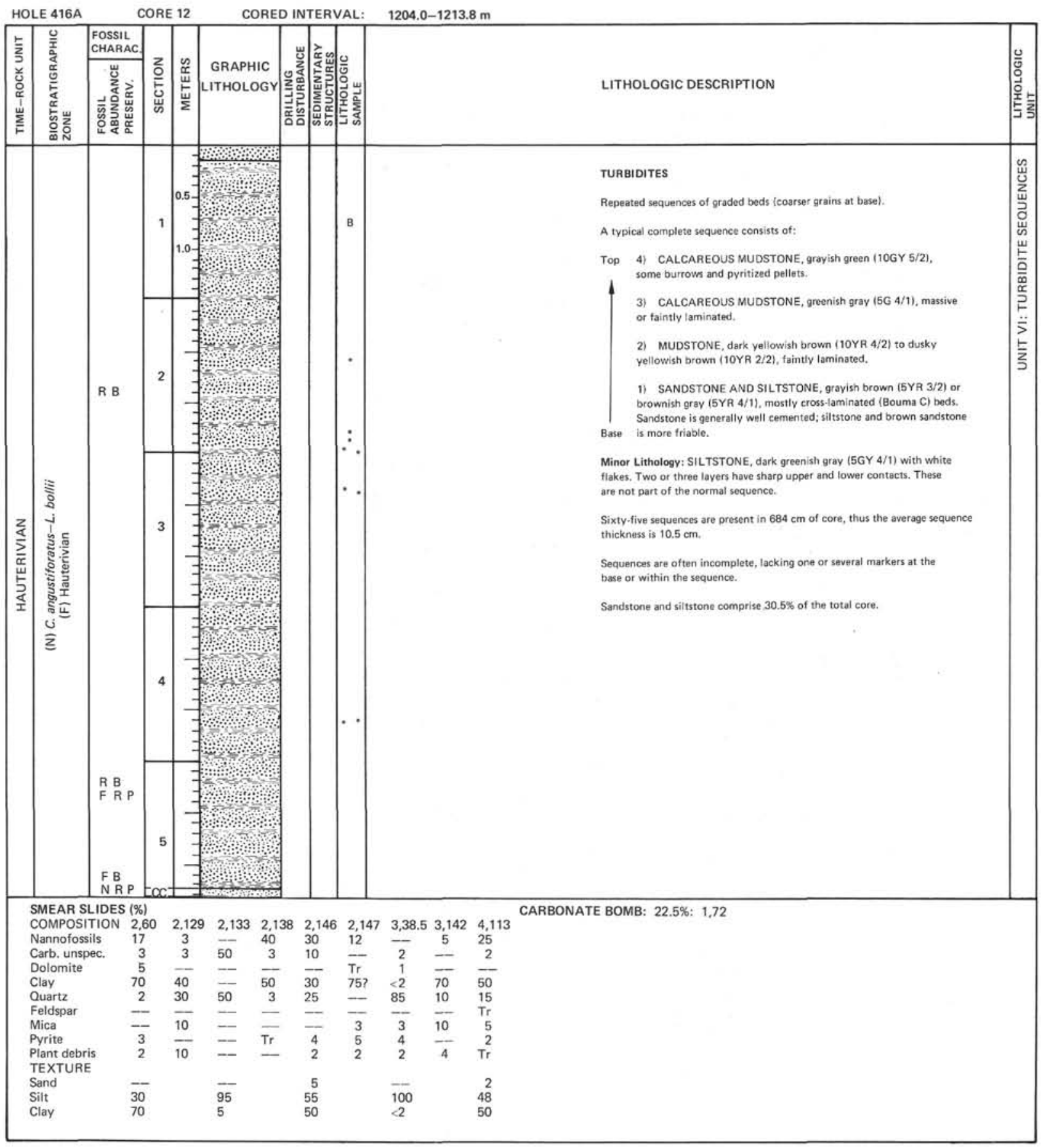




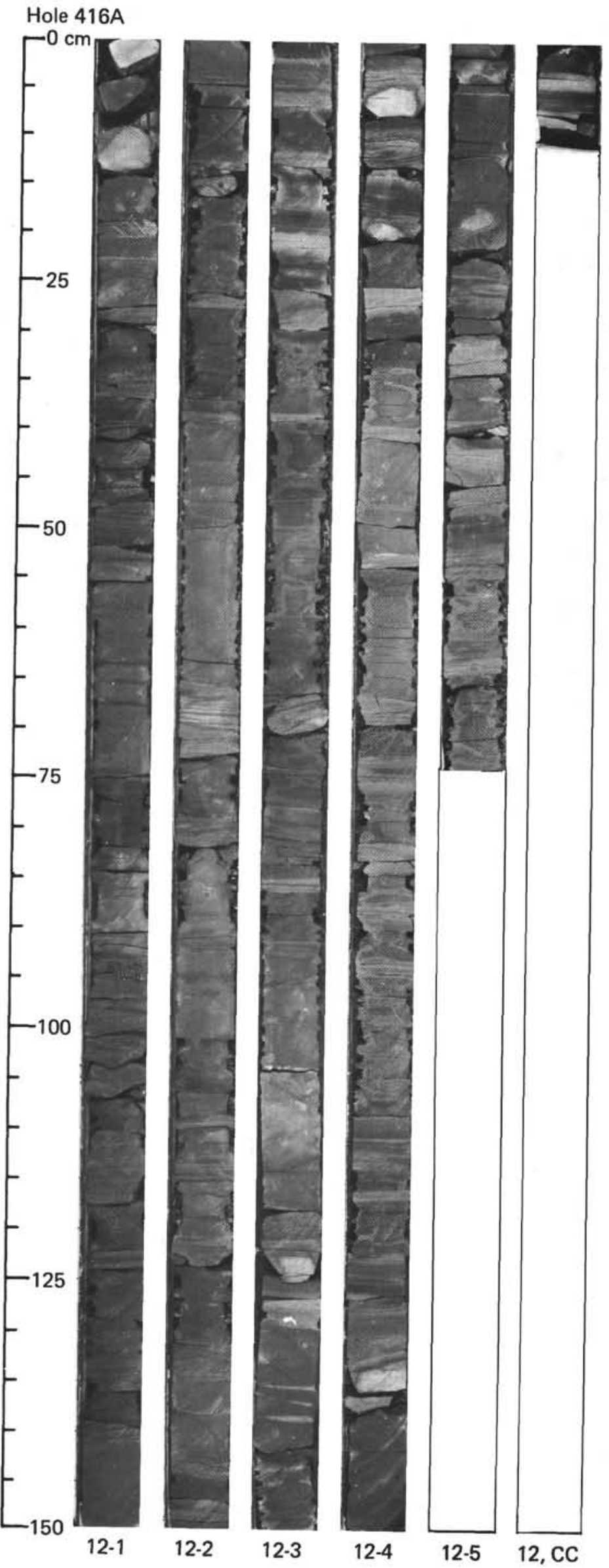




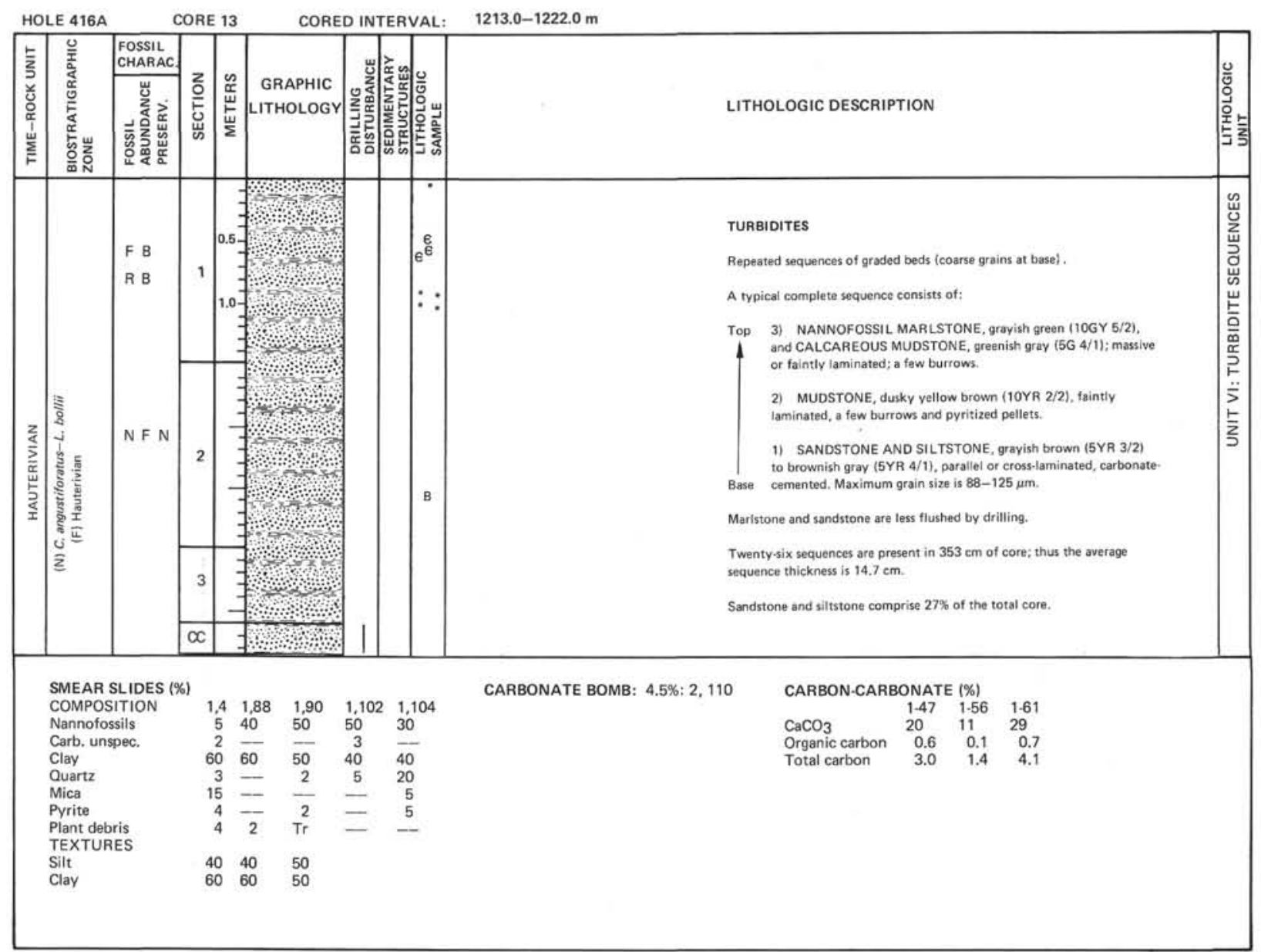


Hole 416A

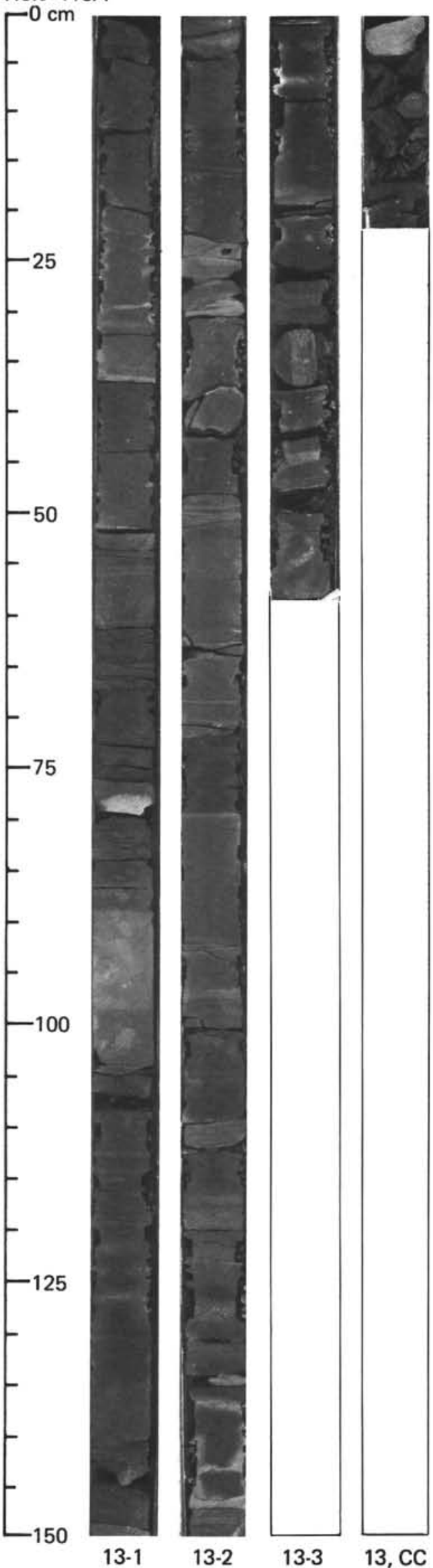




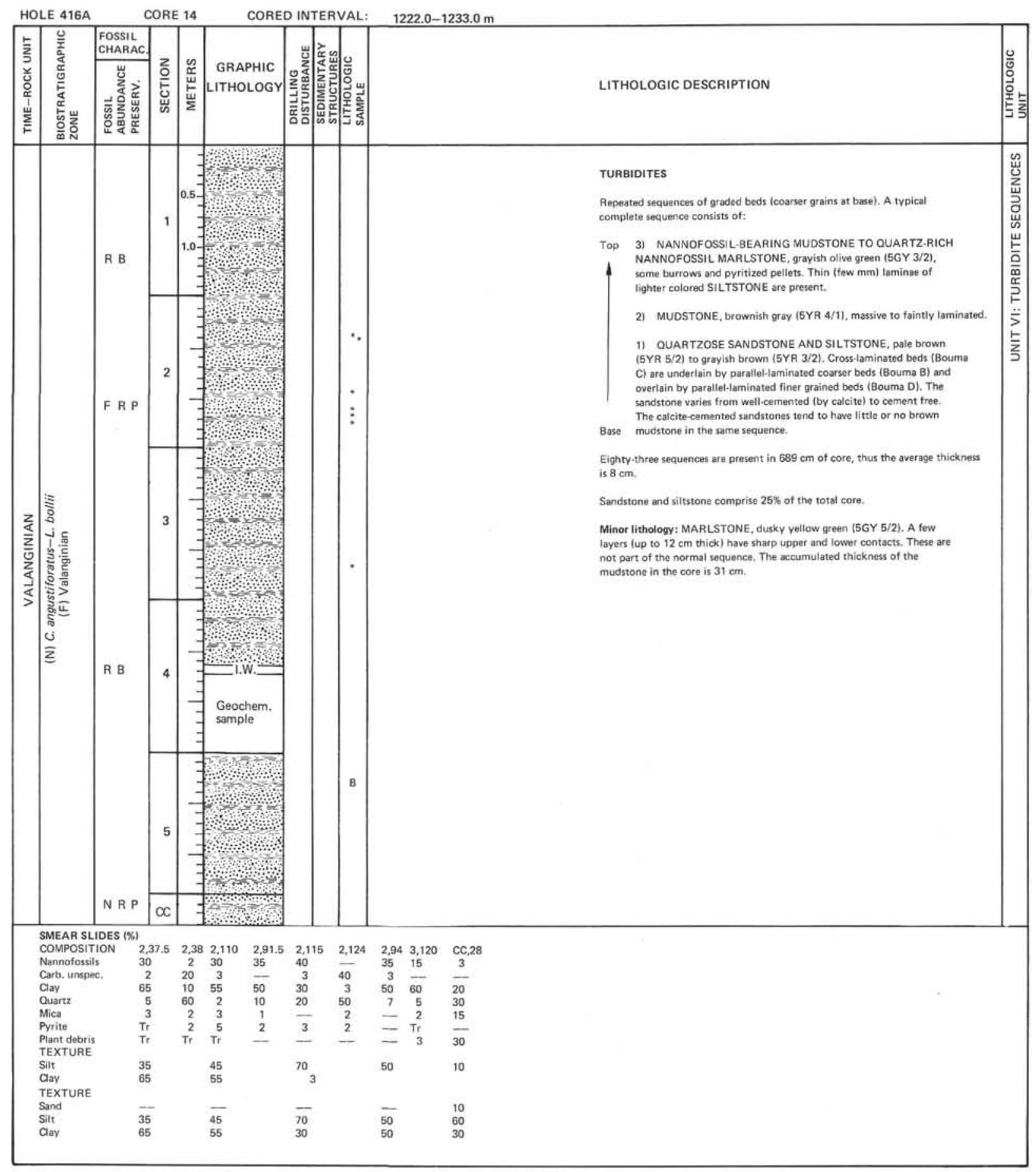


Hole 416A

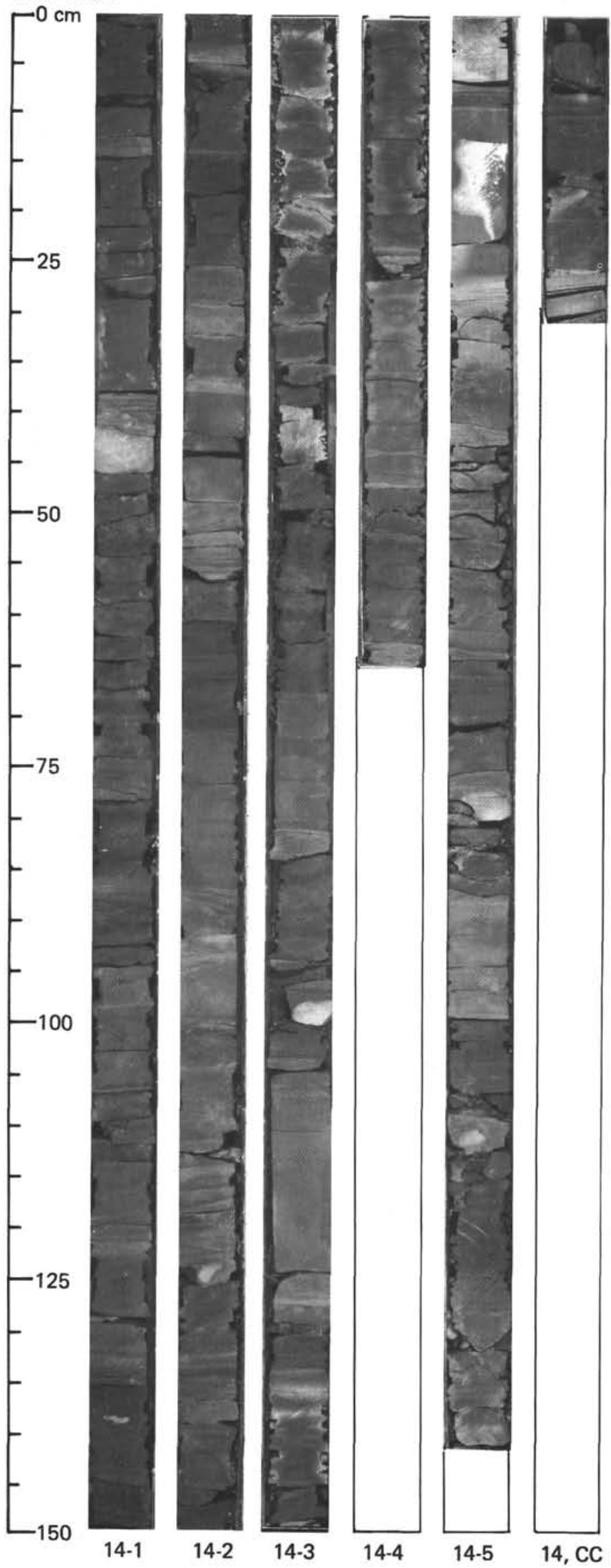




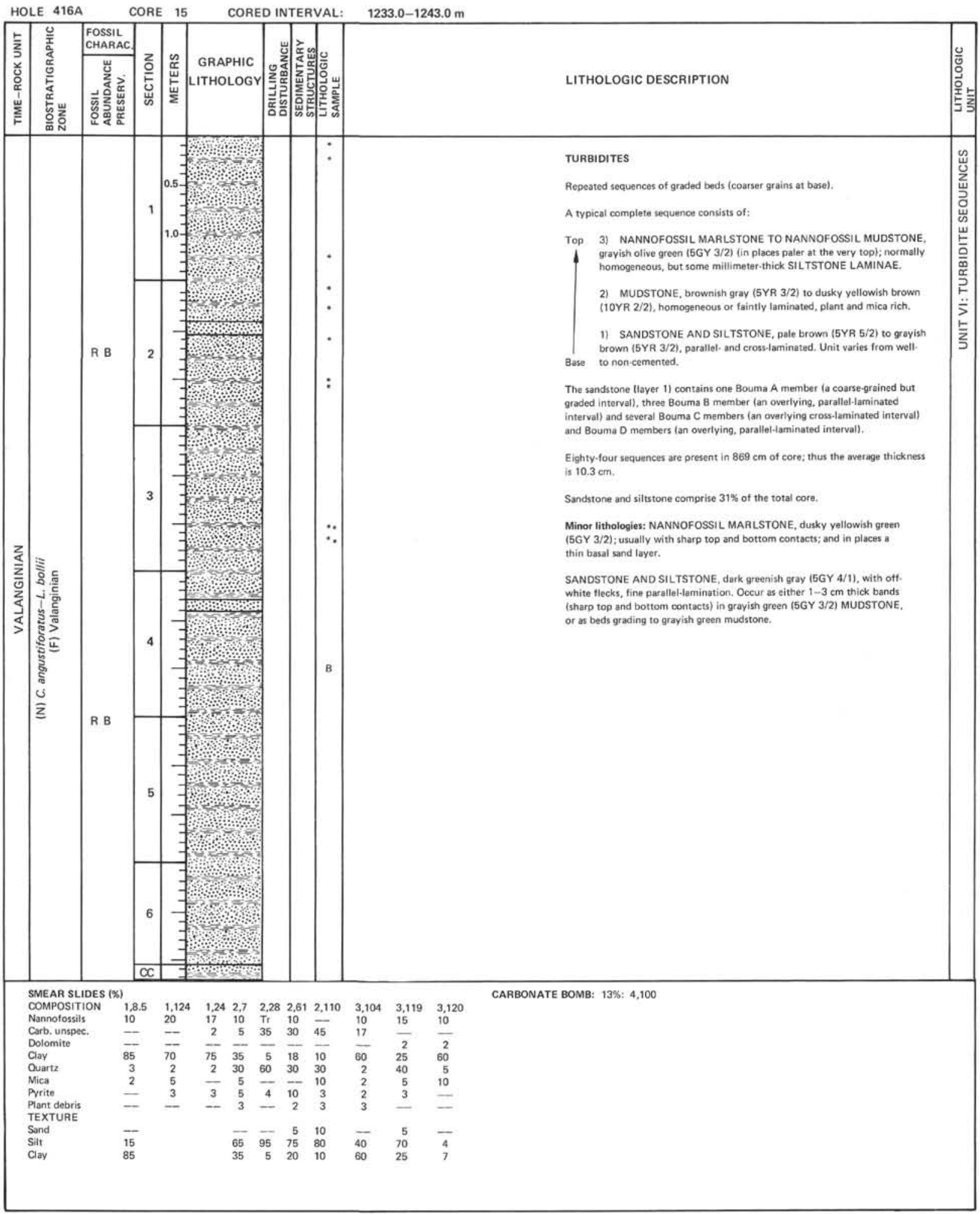


Hole 416A

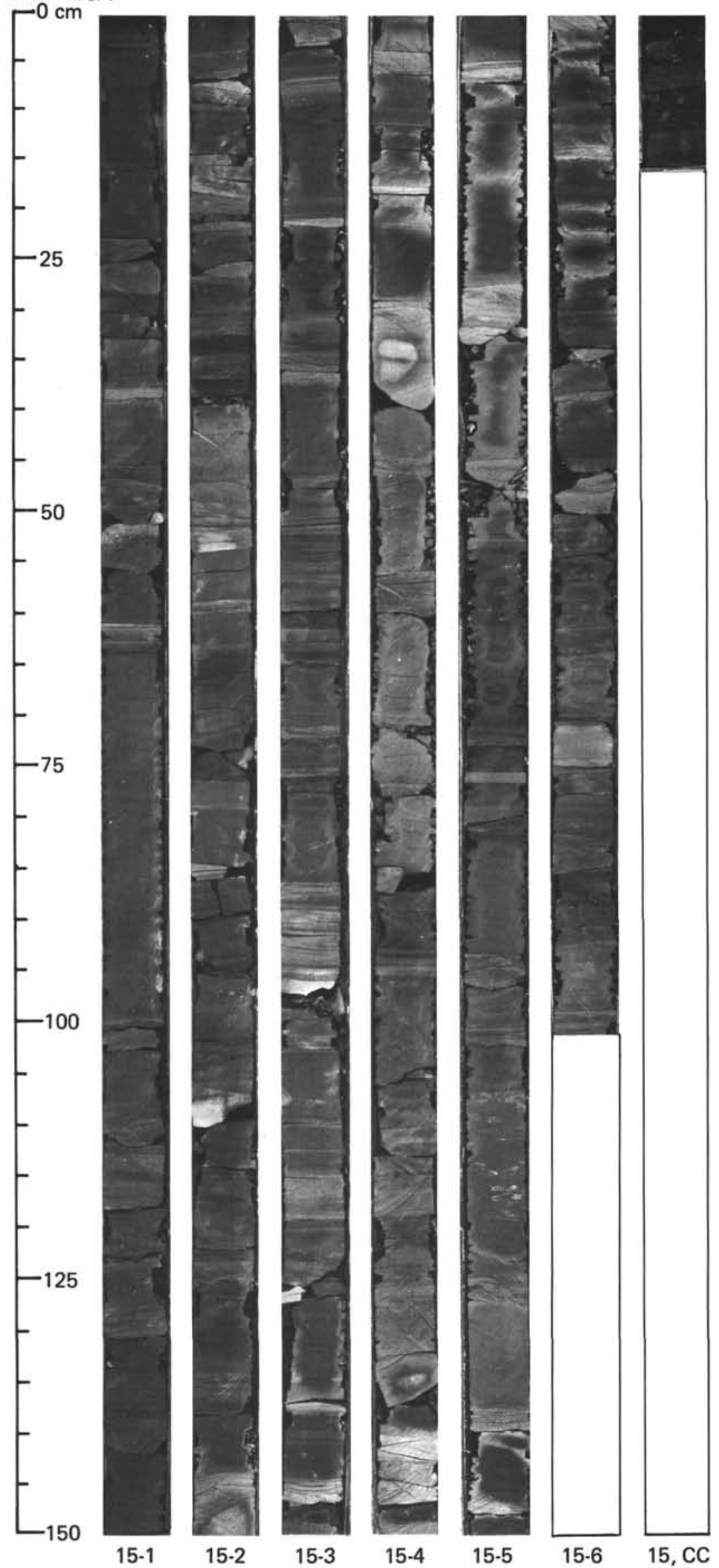




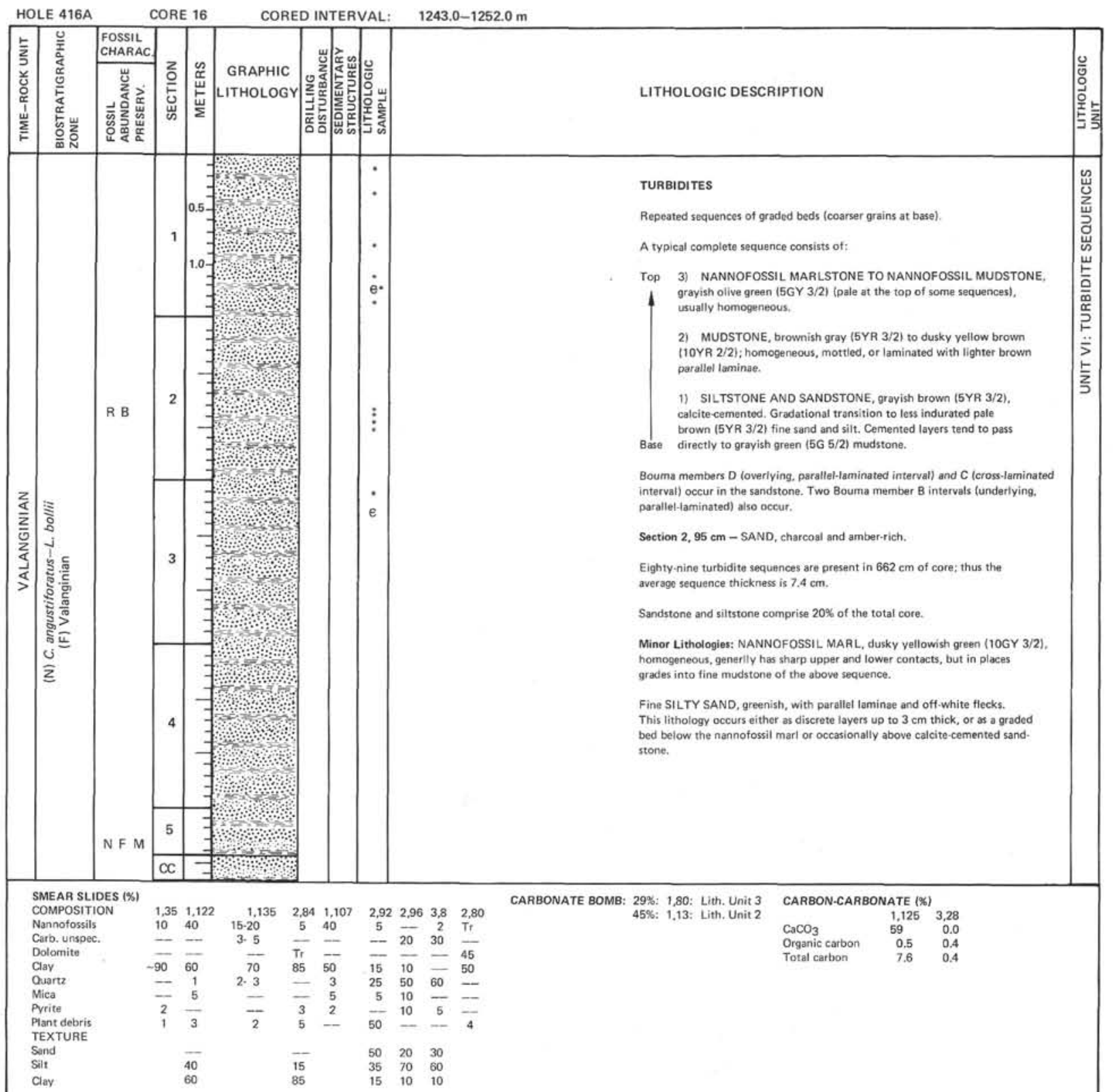


Hole 416A

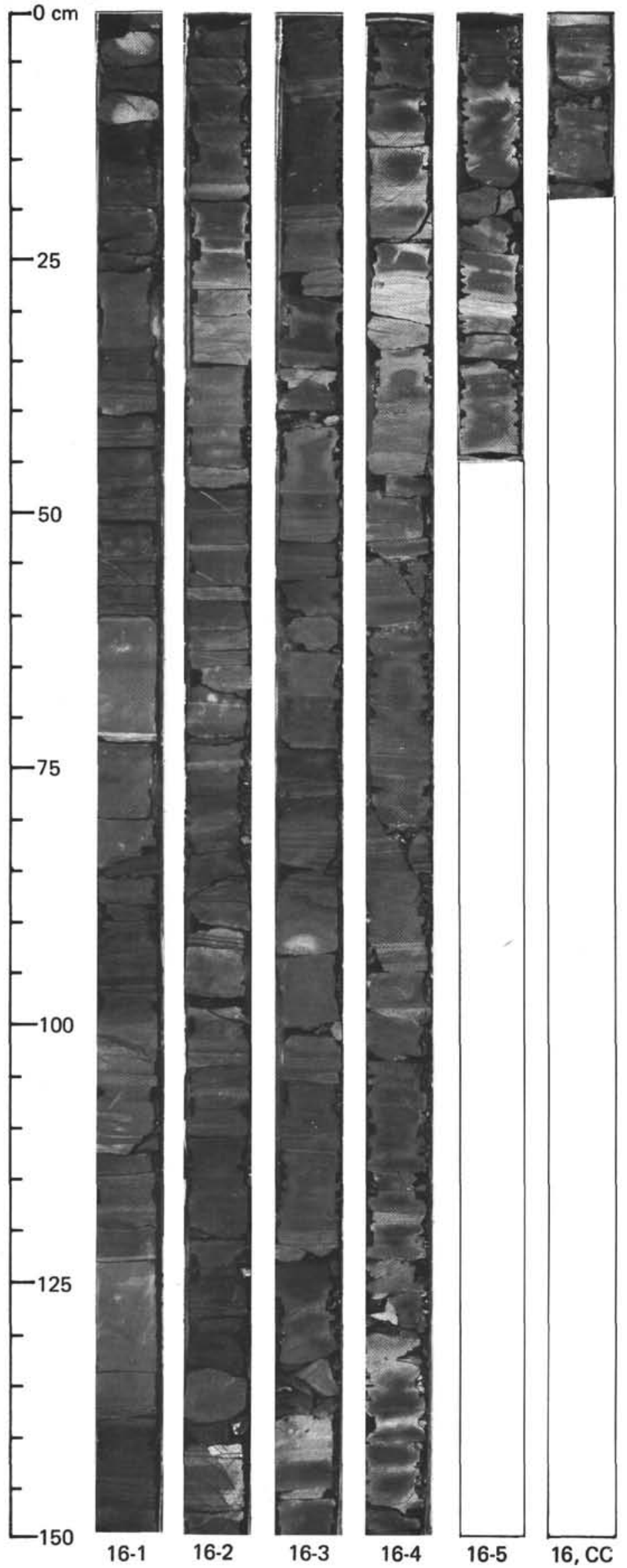




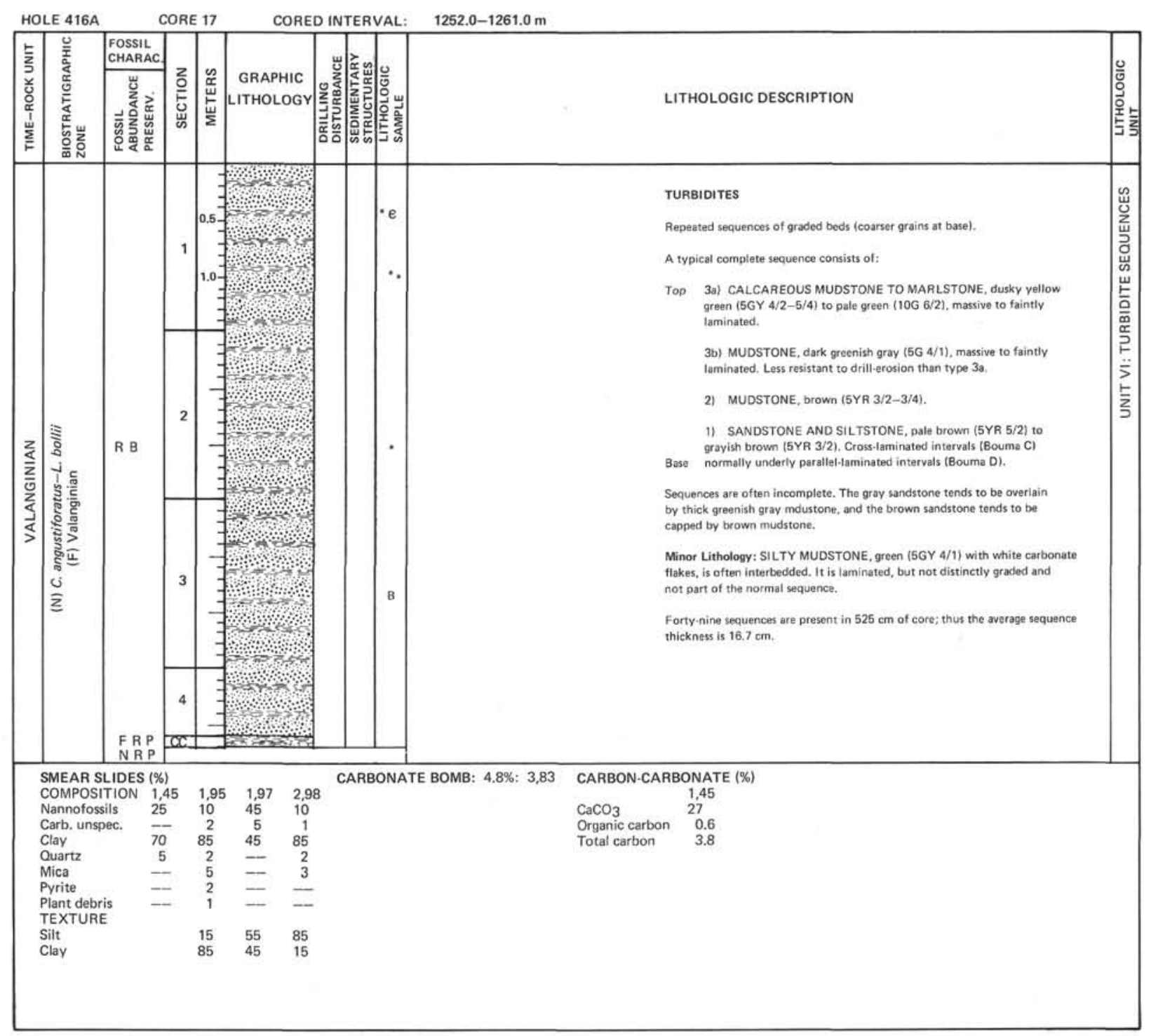


Hole 416A

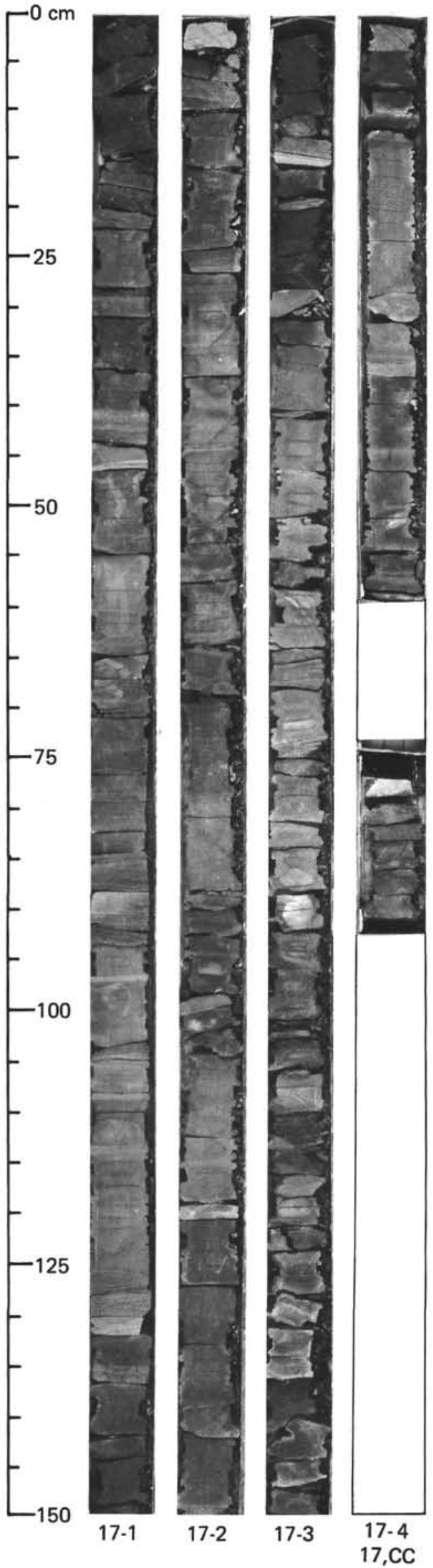




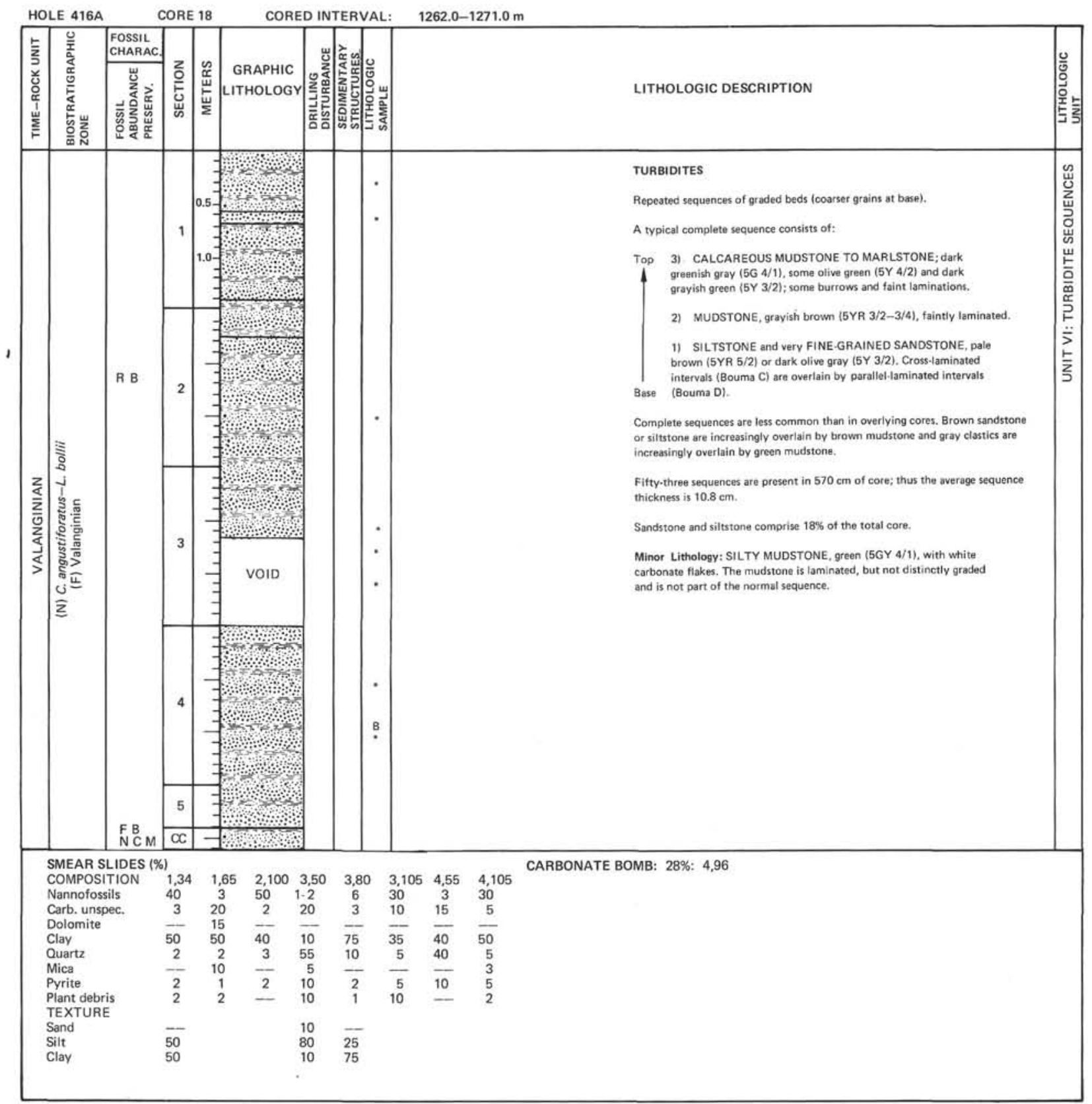


Hole 416A

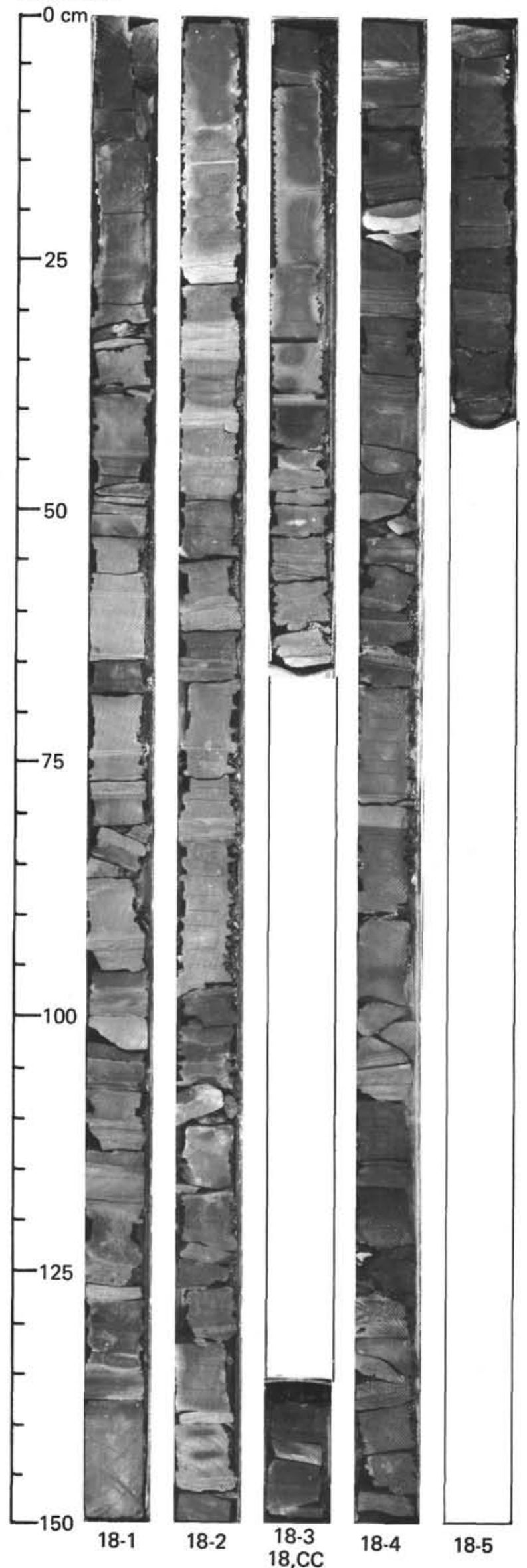


SITE 416

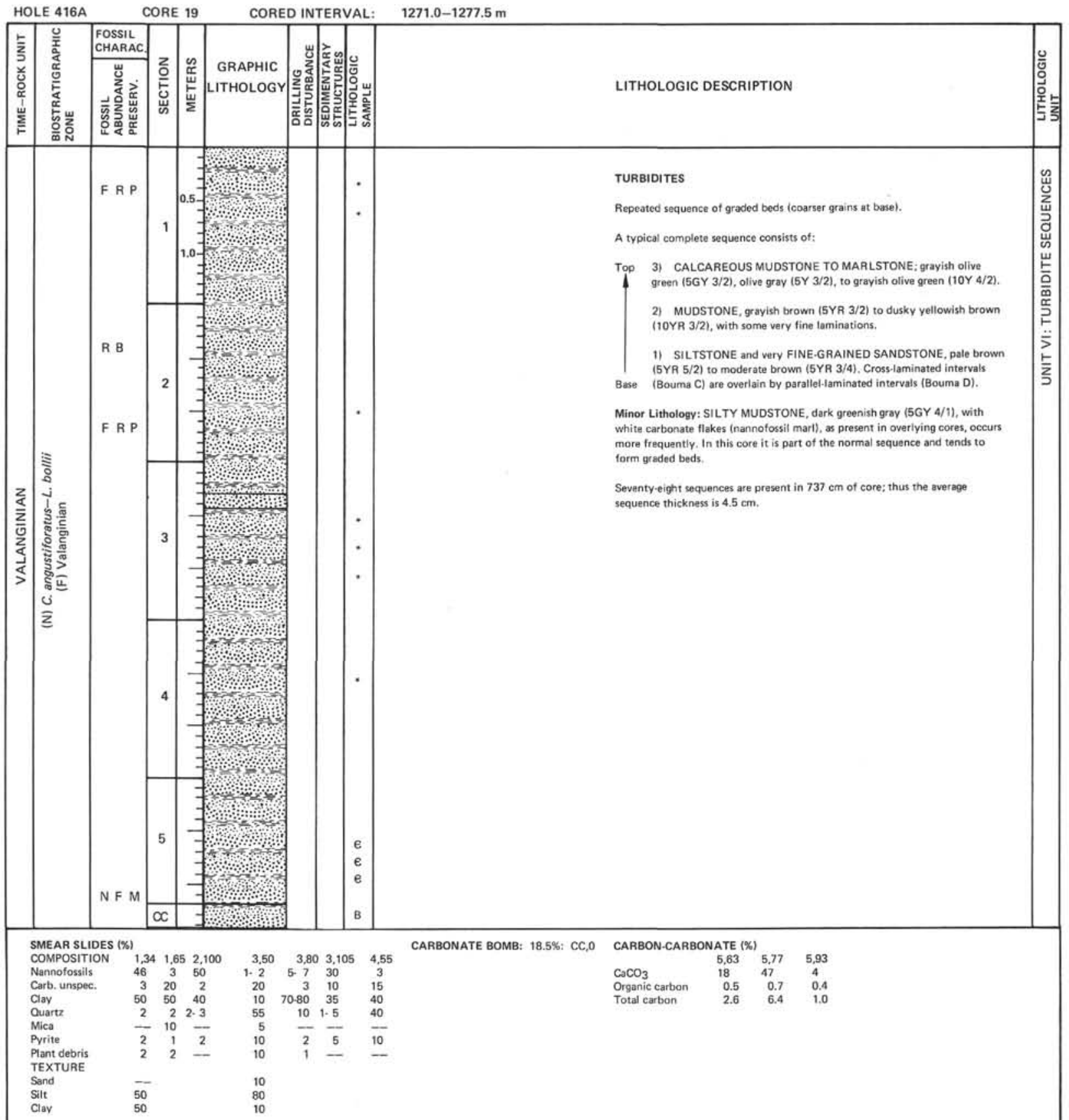


Hole 416A

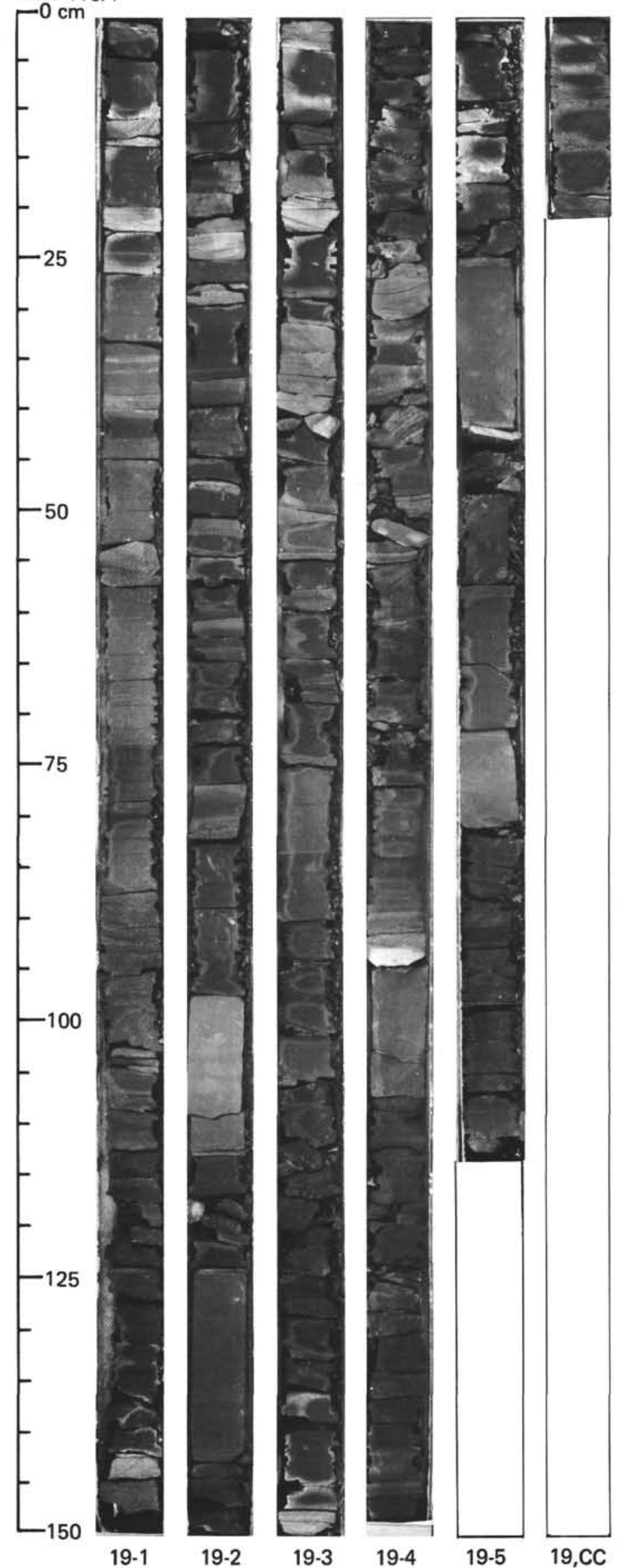




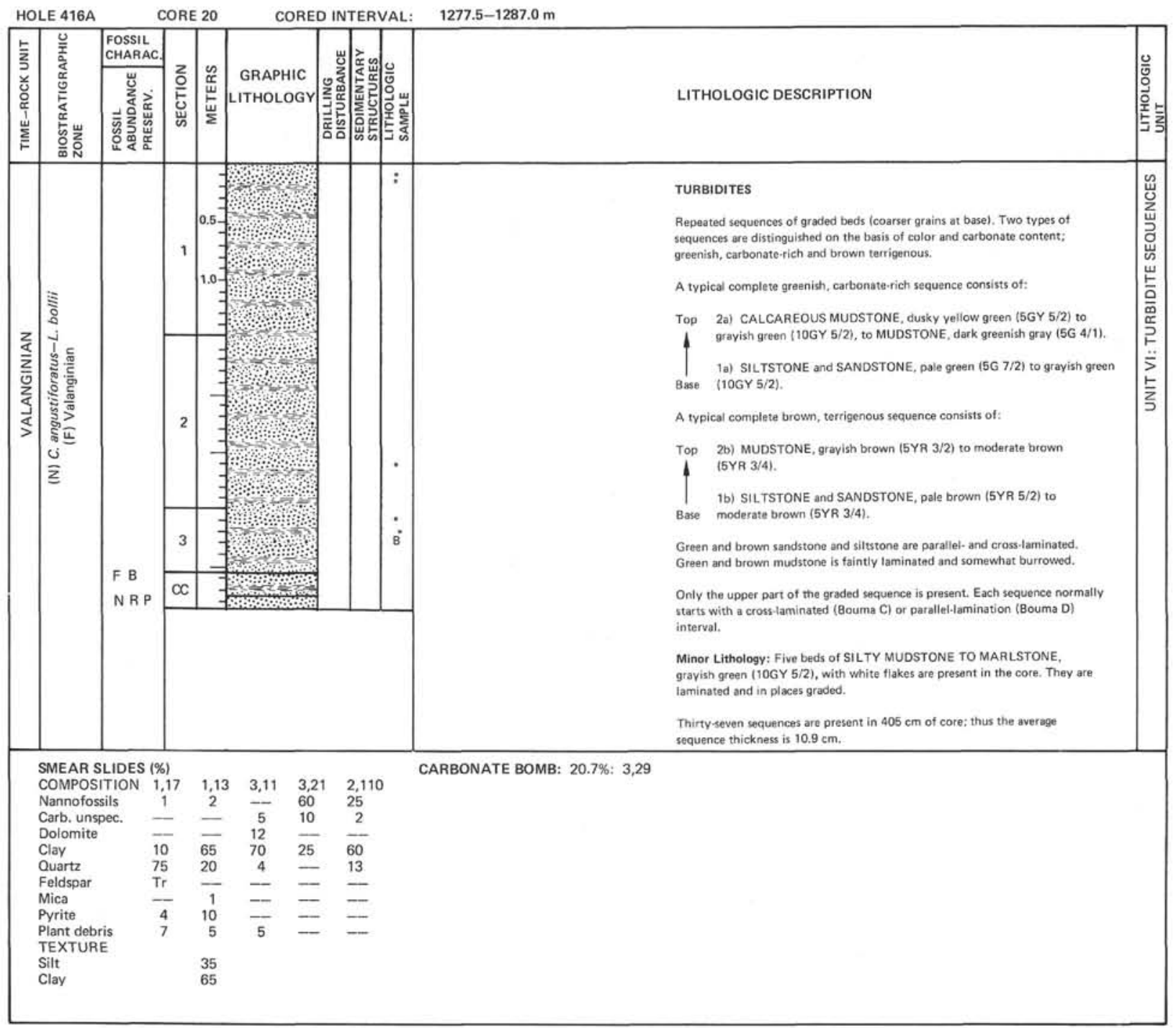


Hole 416A

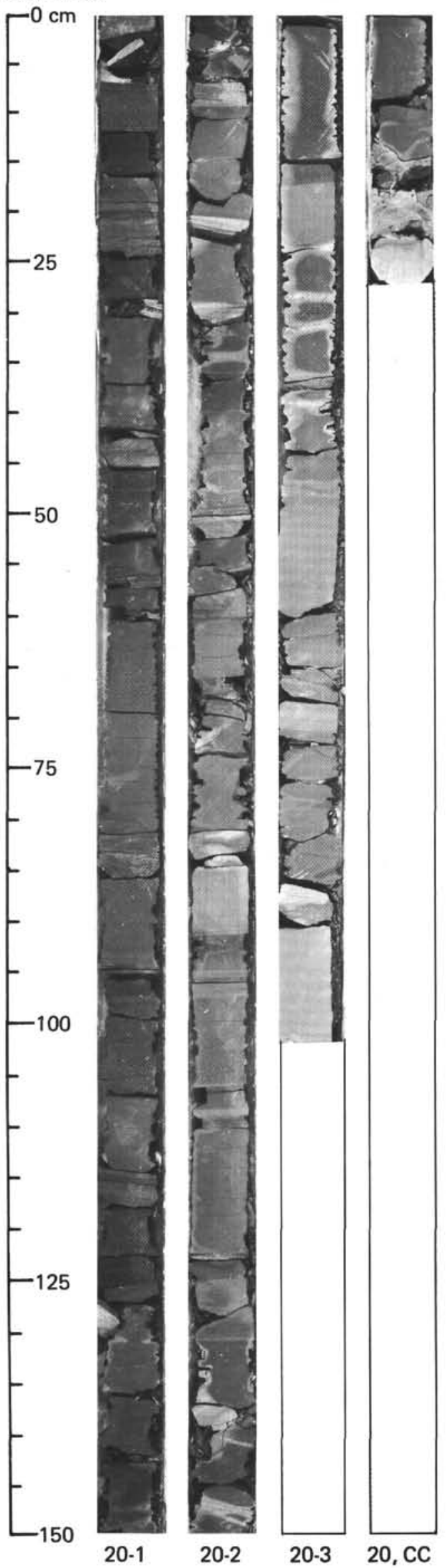




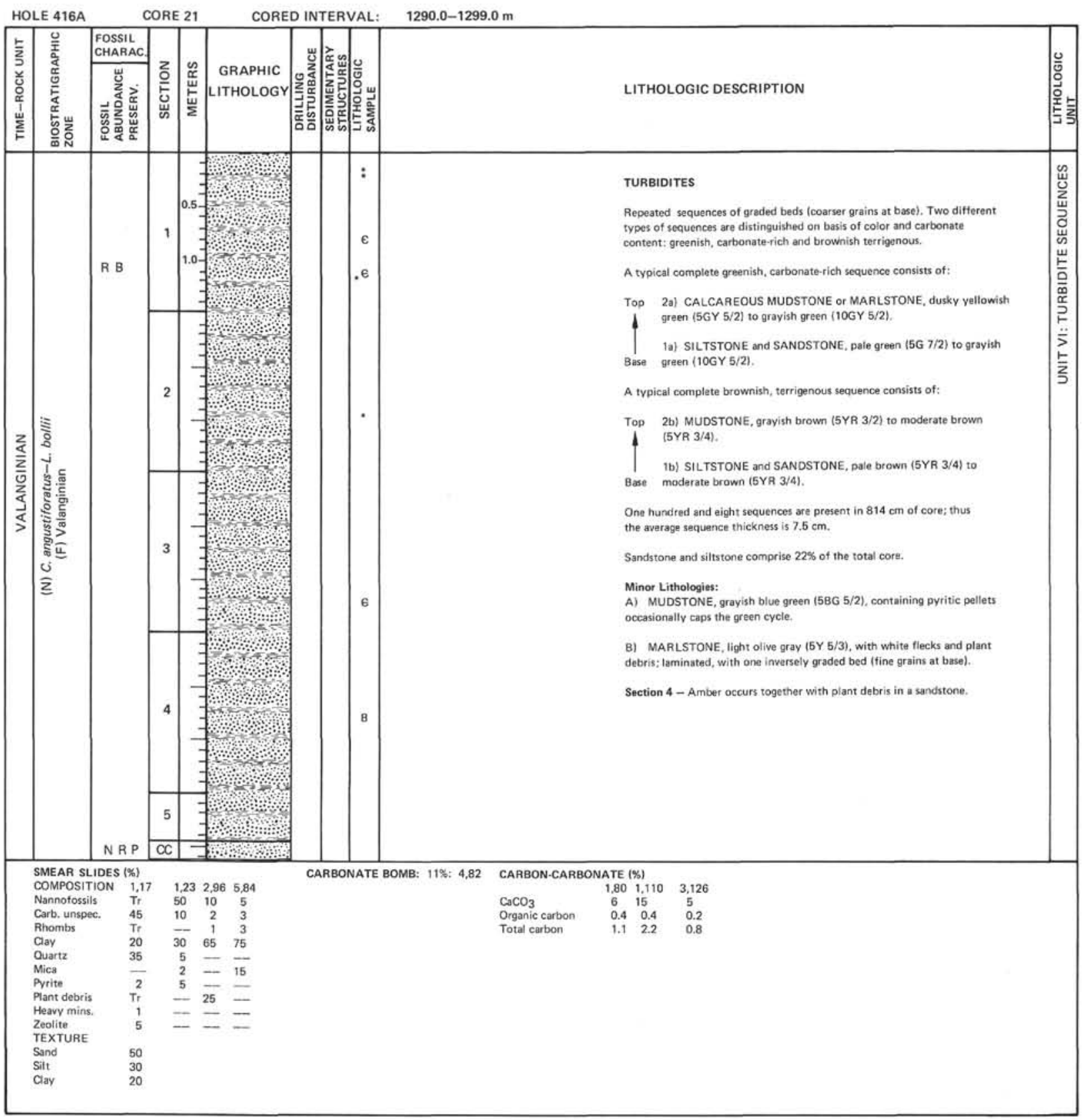




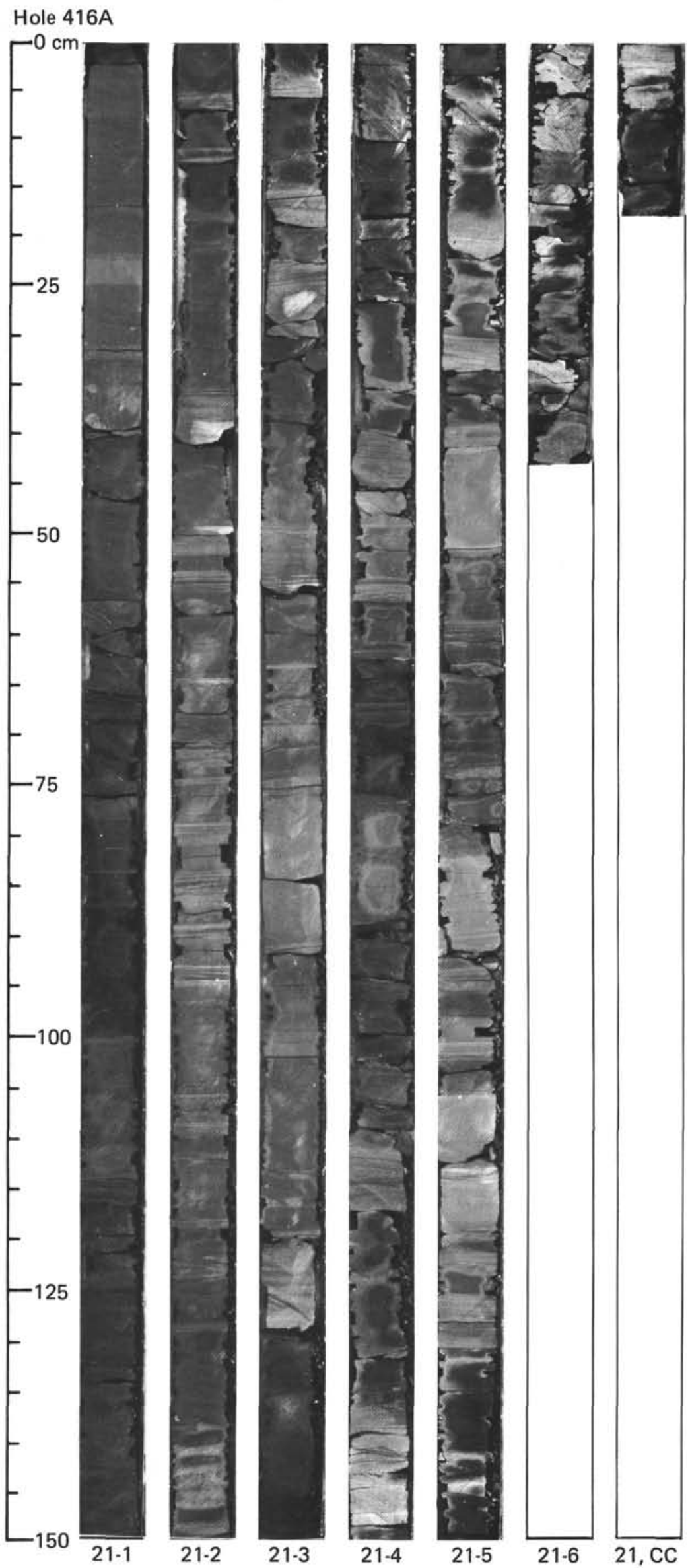




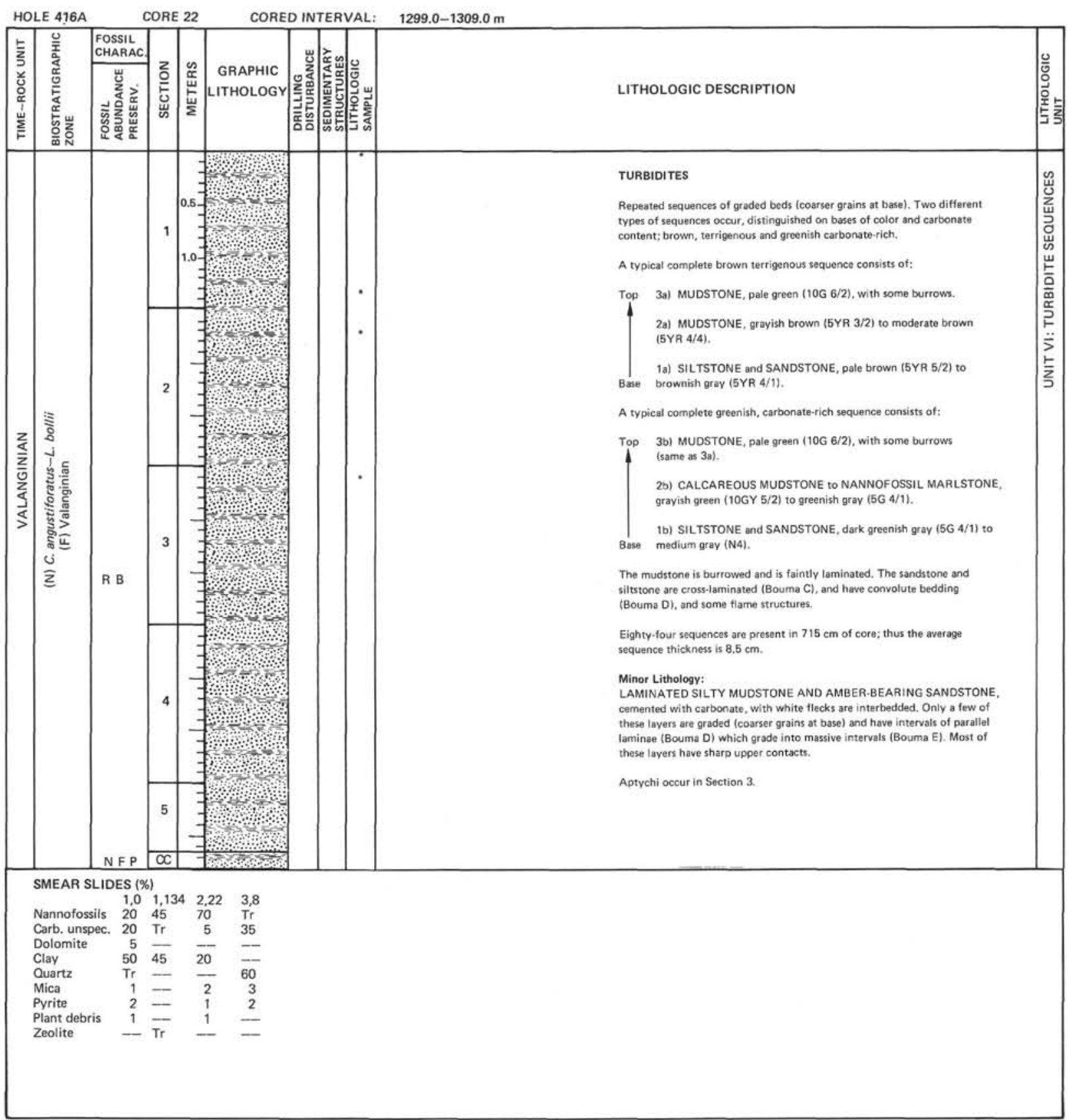




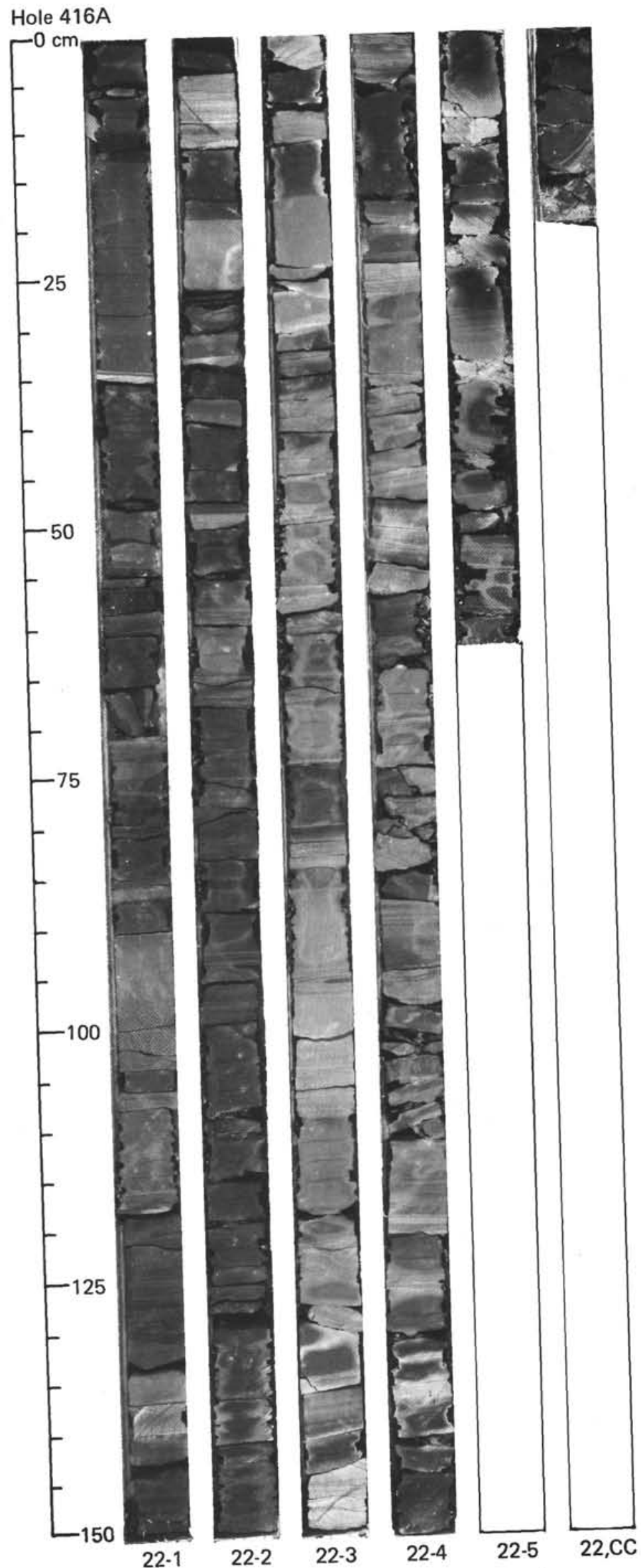




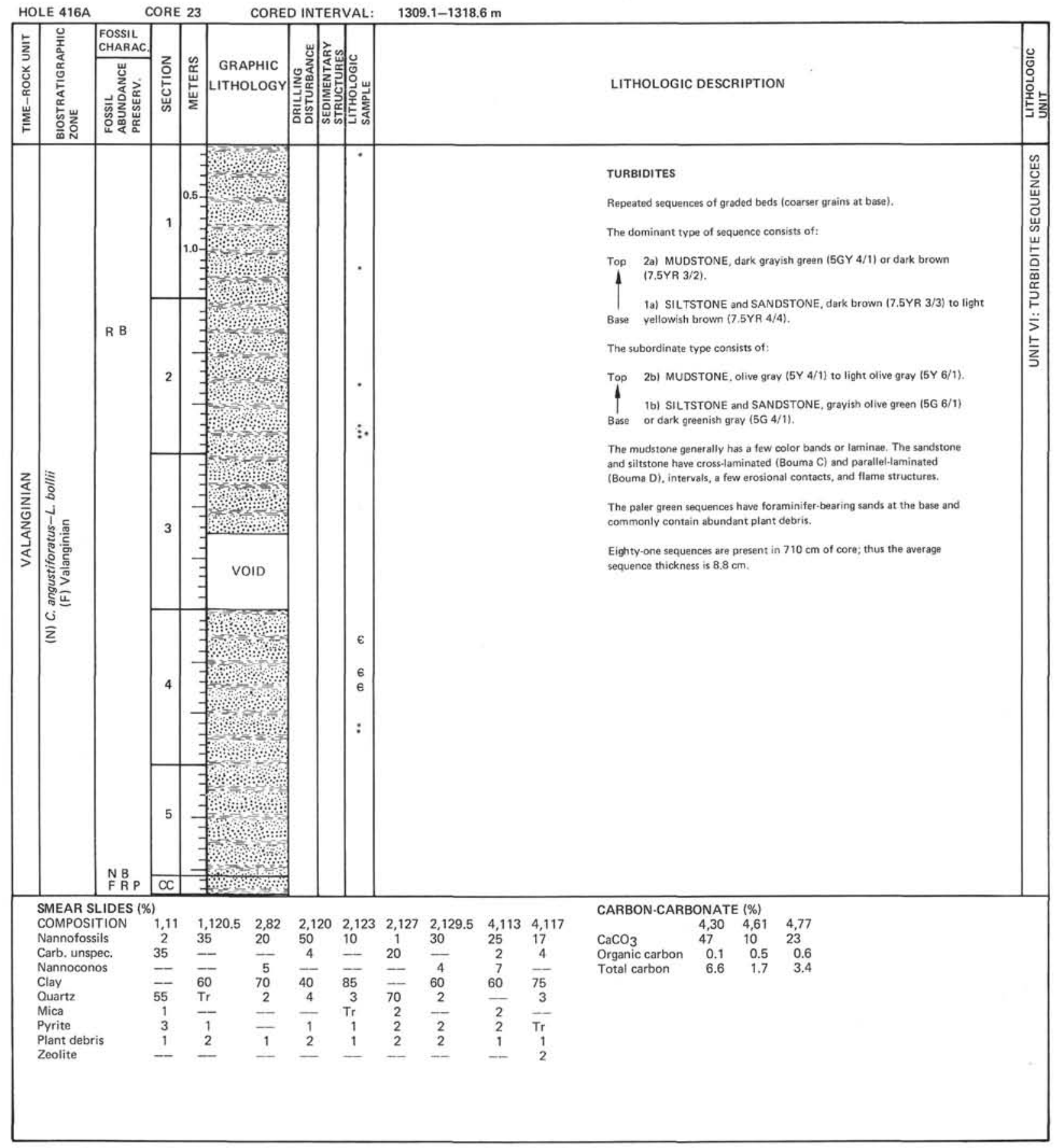


Hole 416A

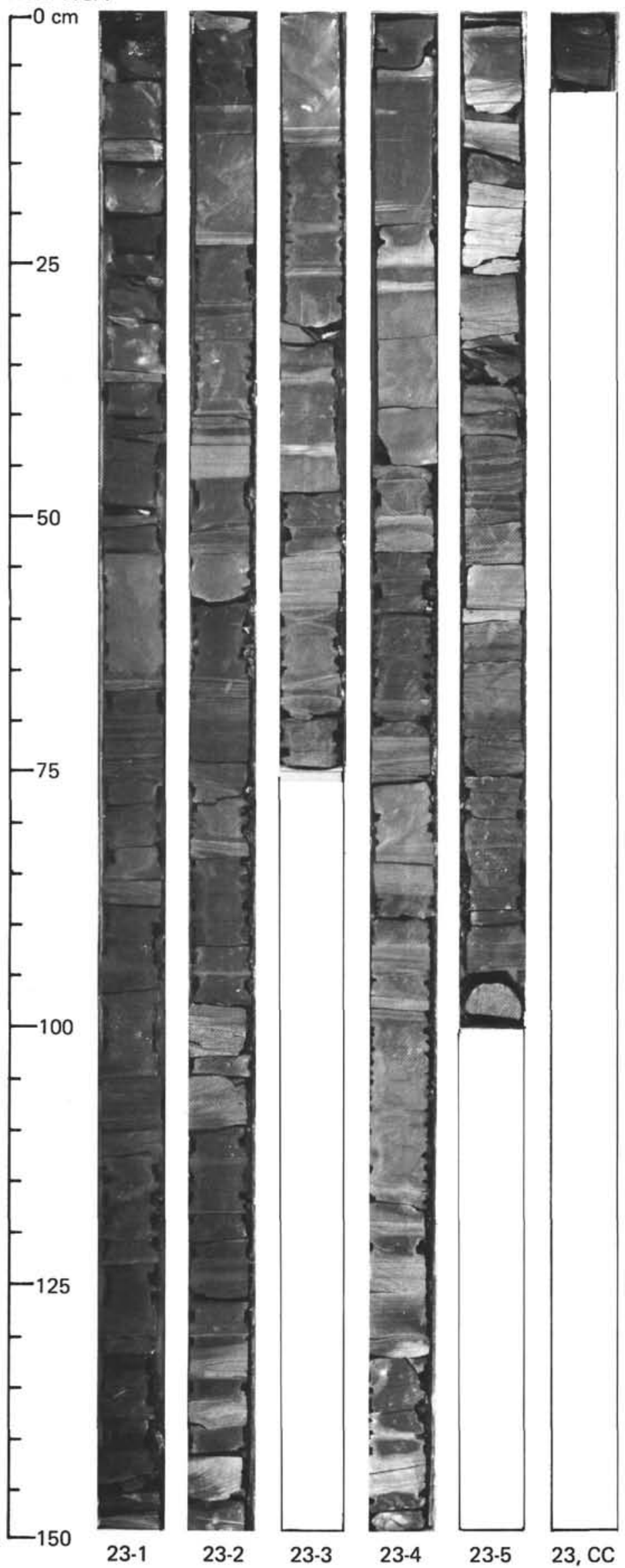




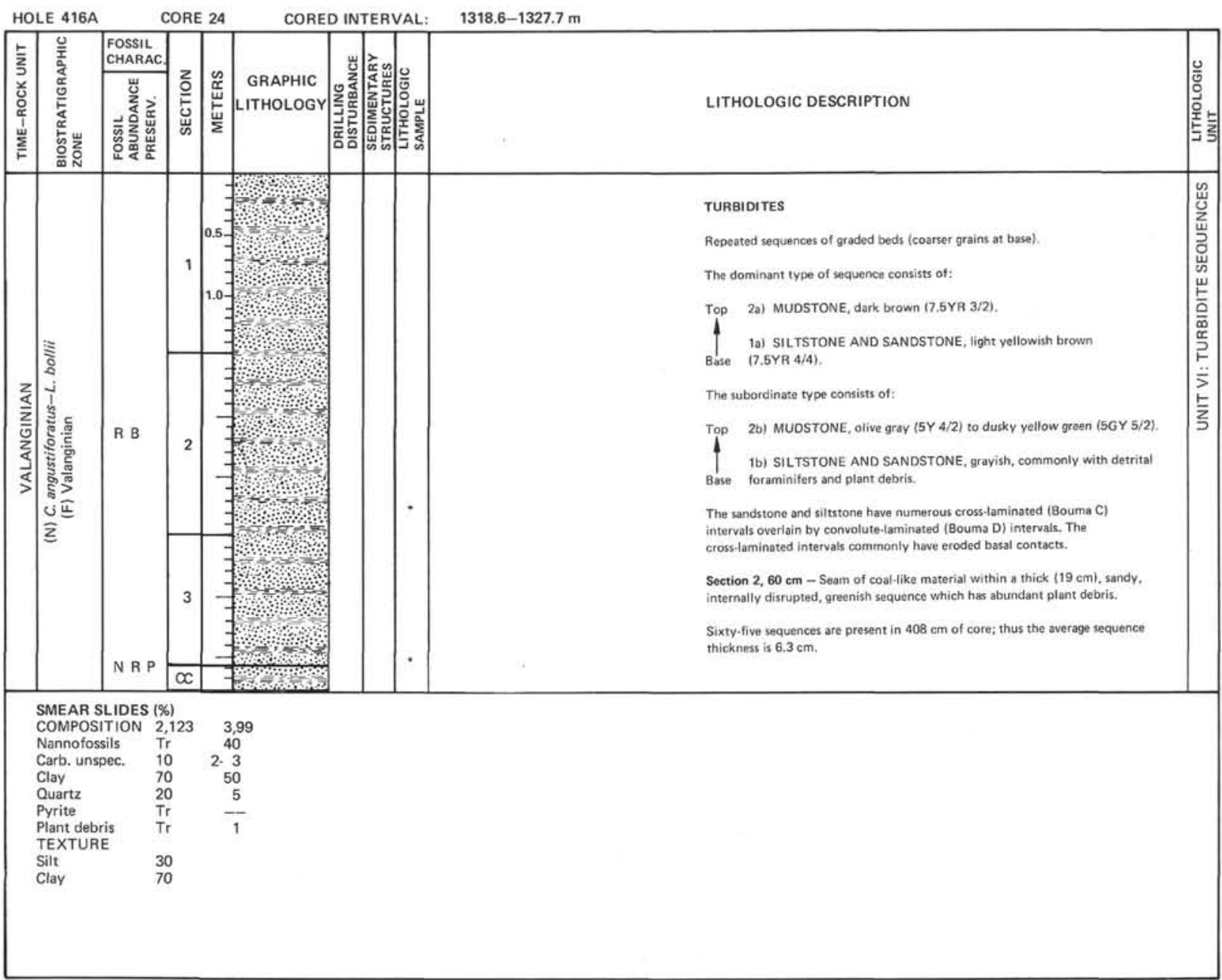


Hole 416A

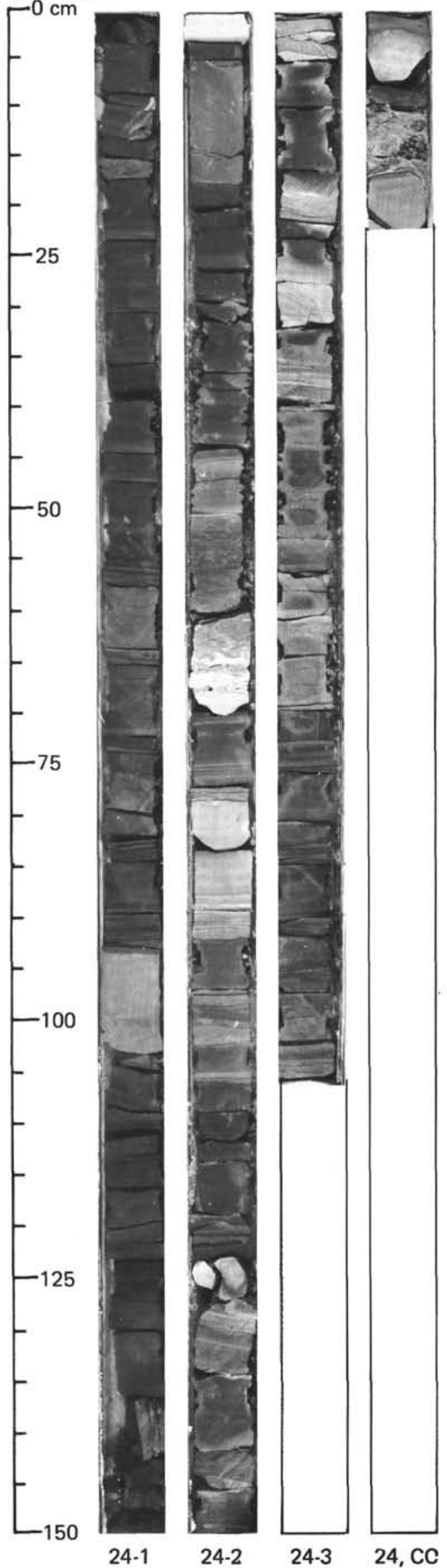




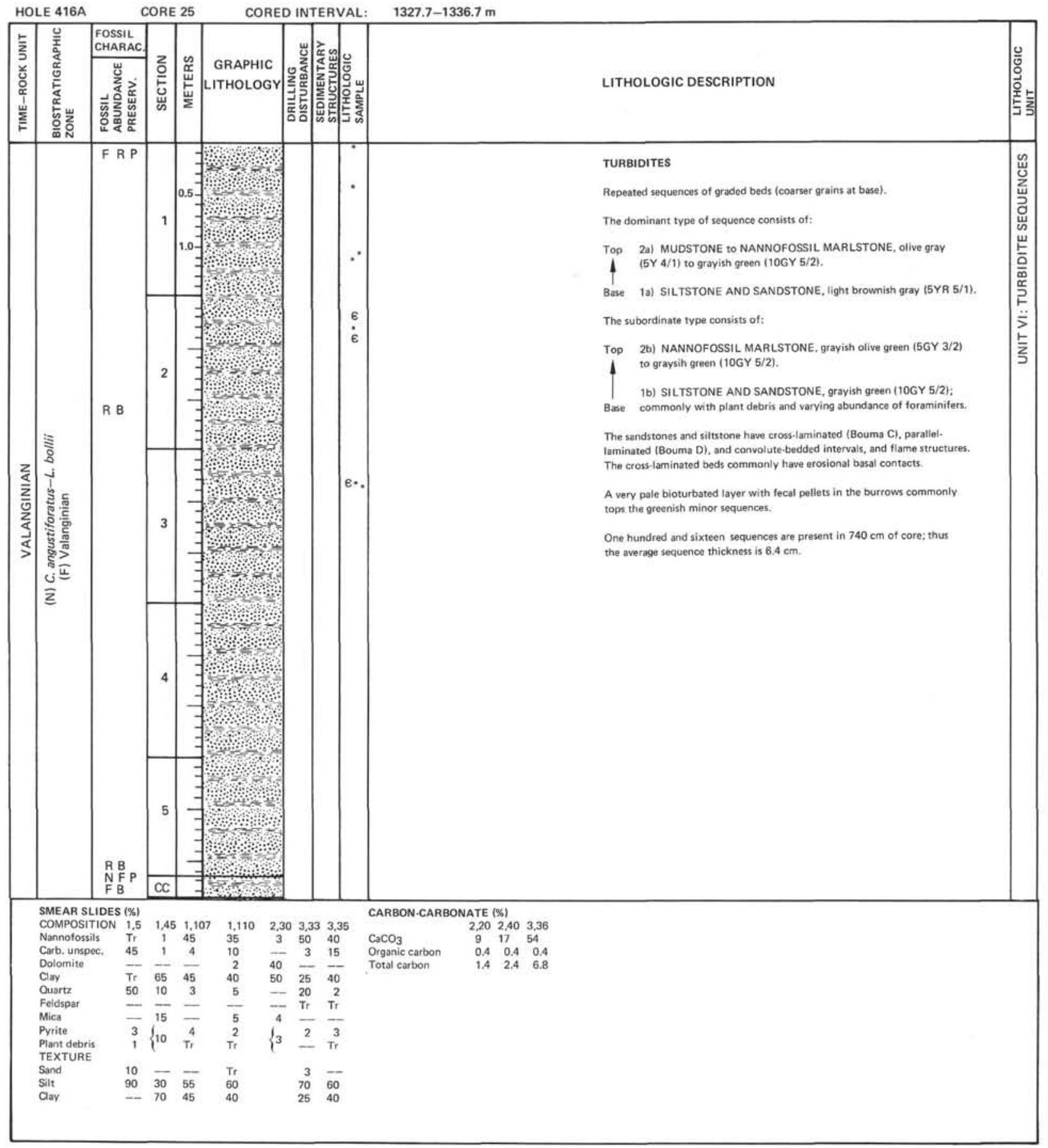


Hole 416A

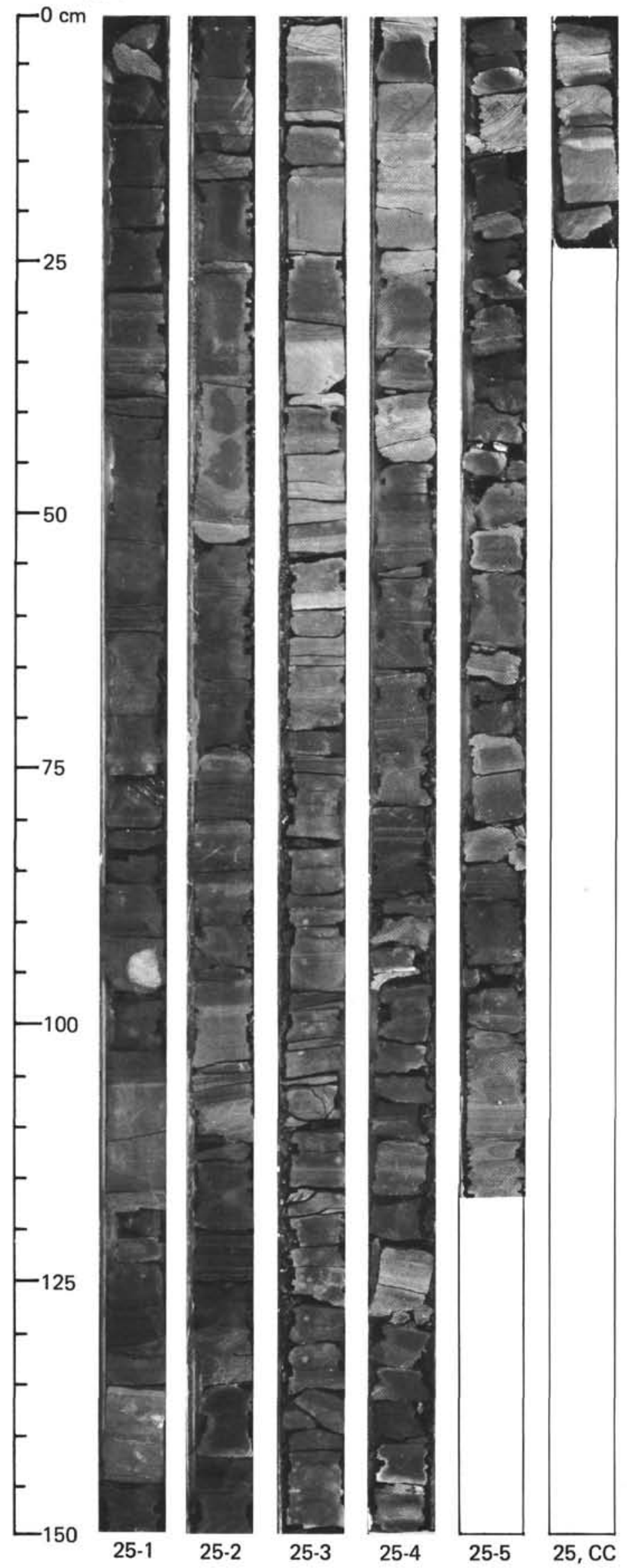




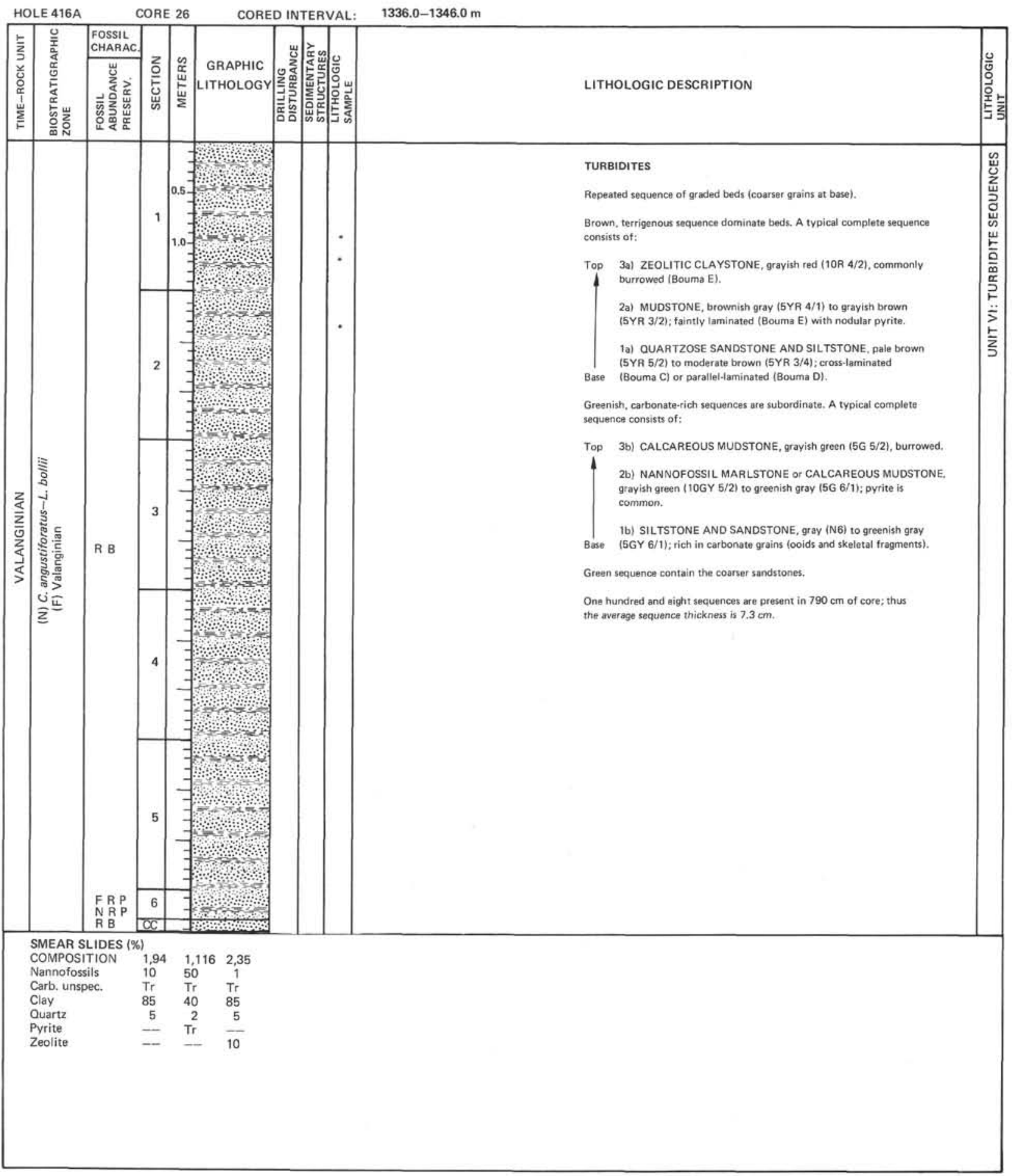


Hole 416A

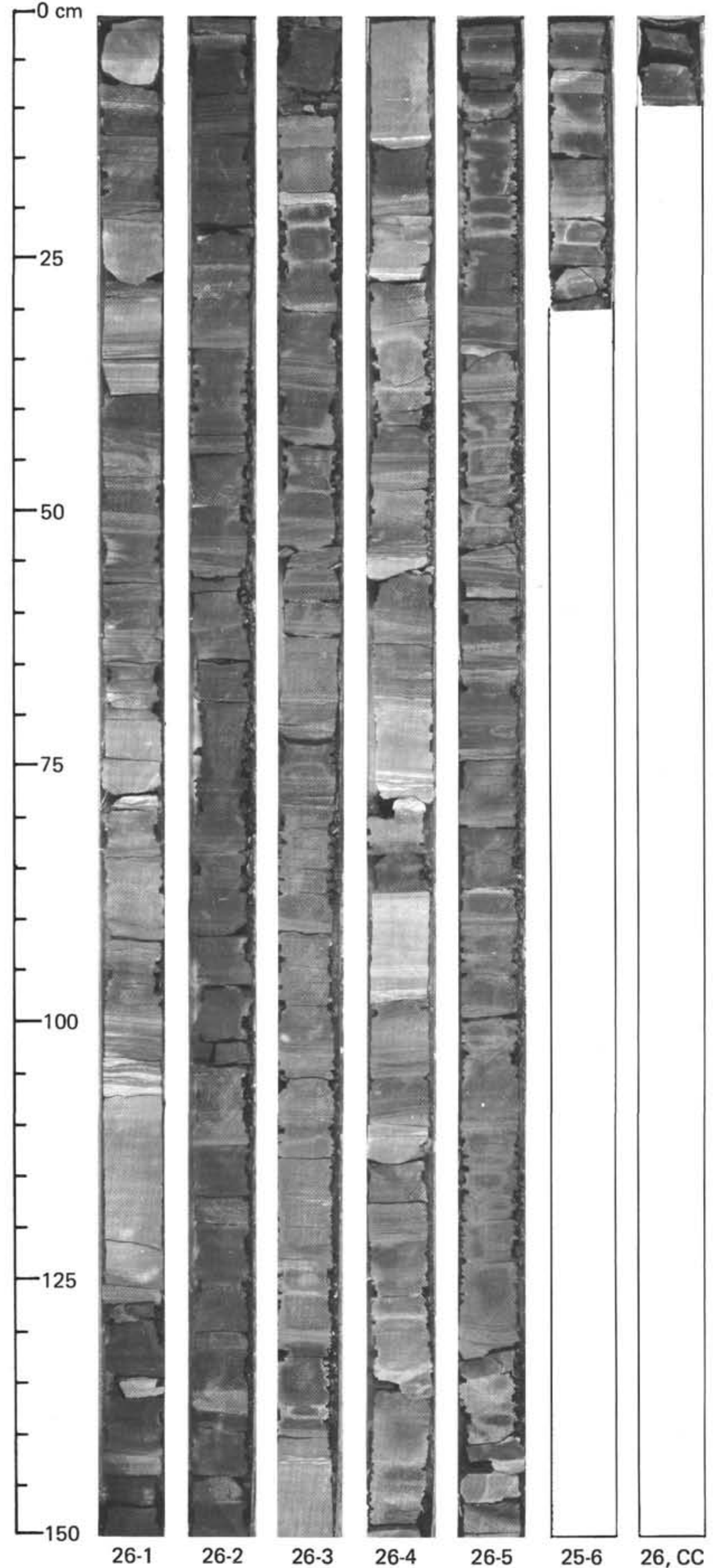




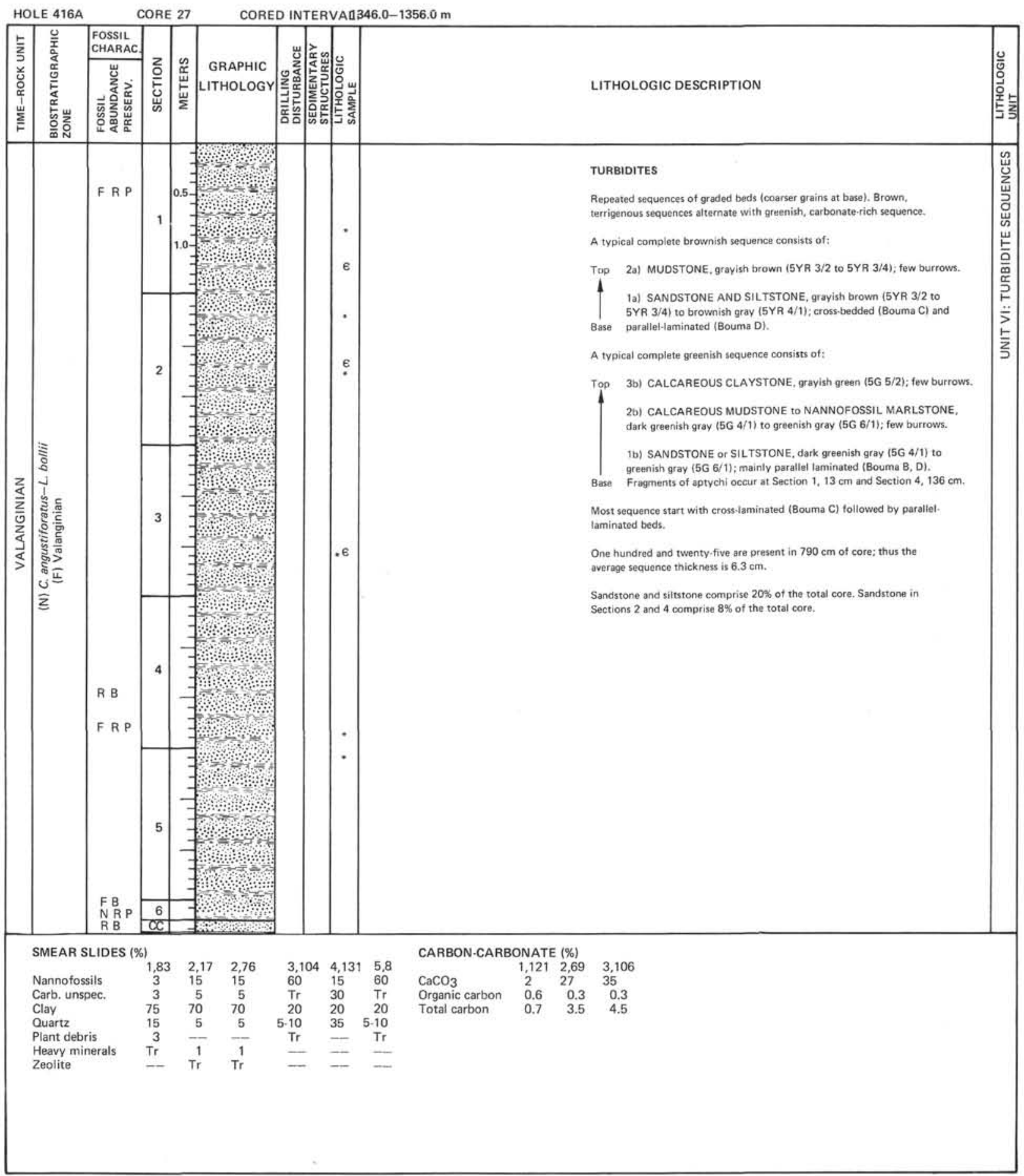




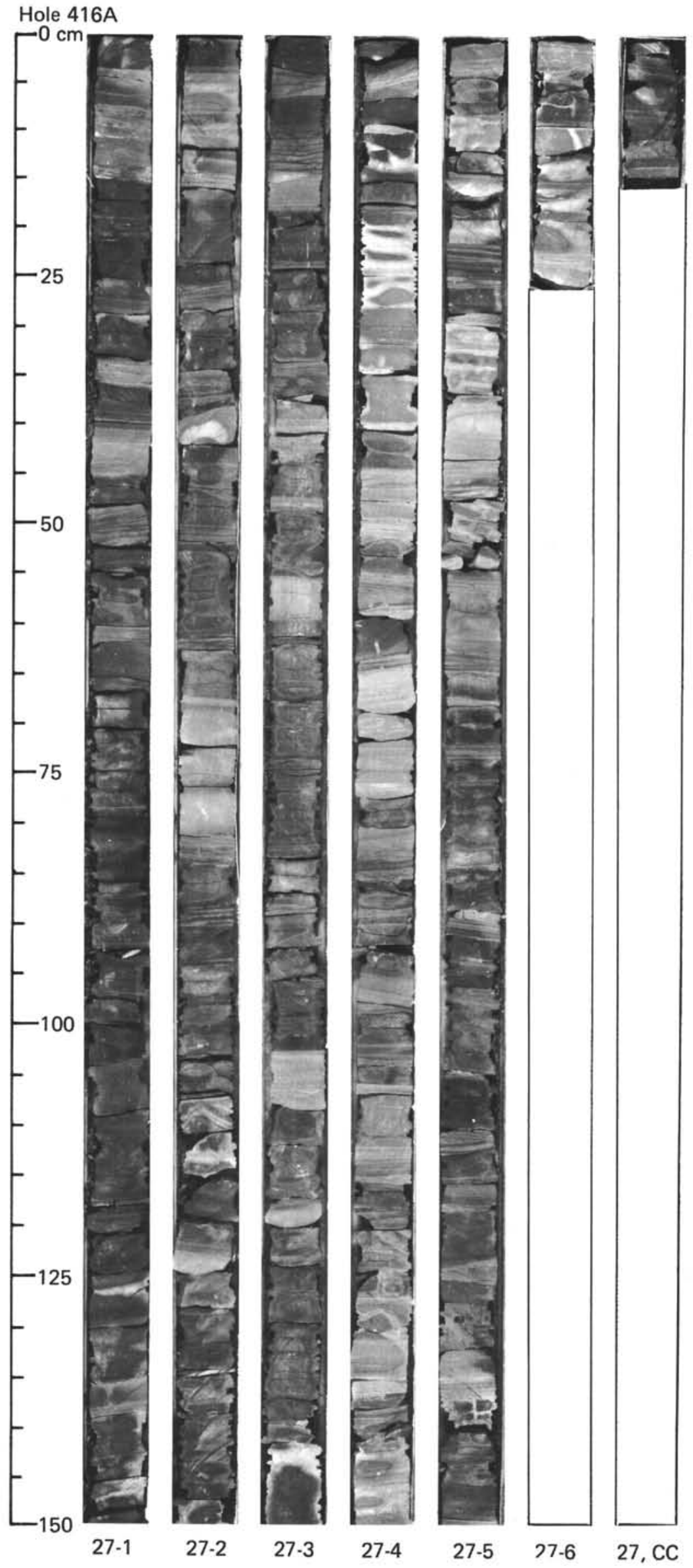




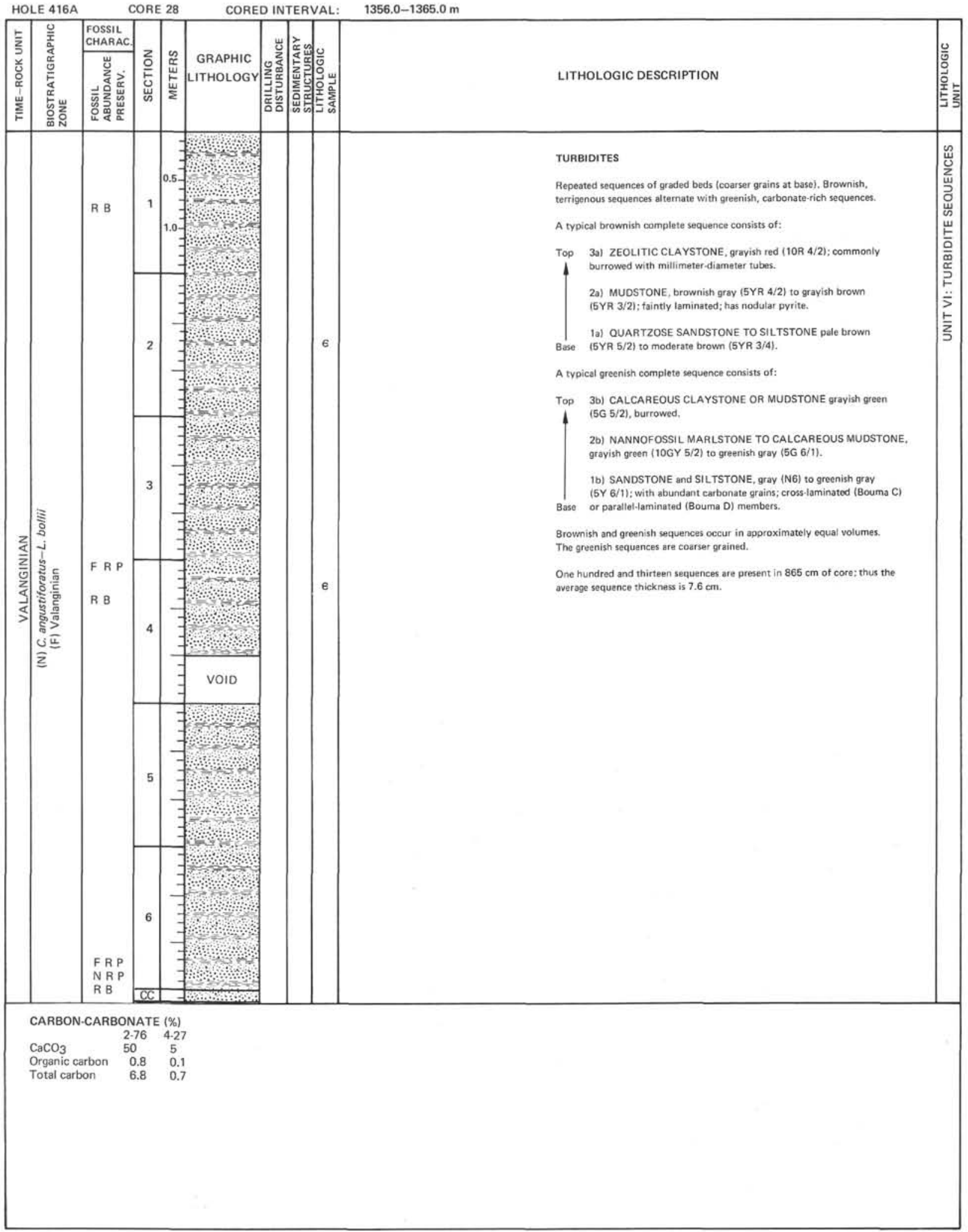


Hole 416A

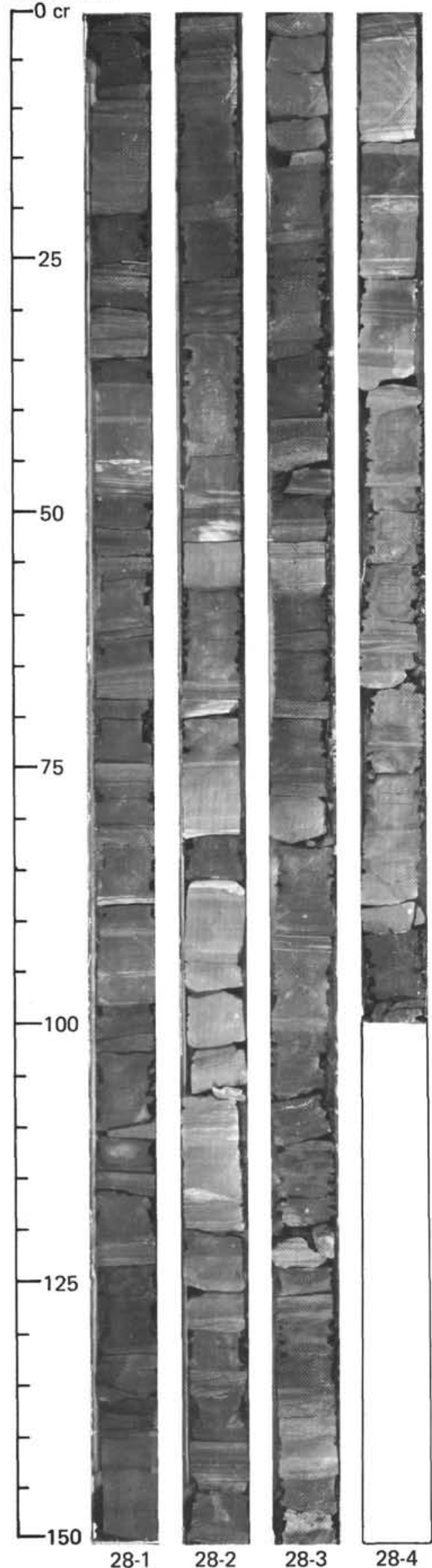

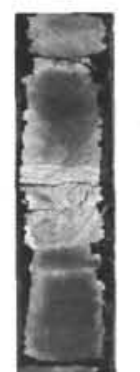
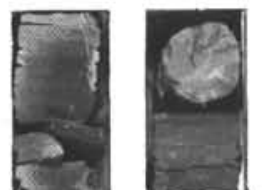

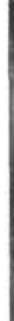
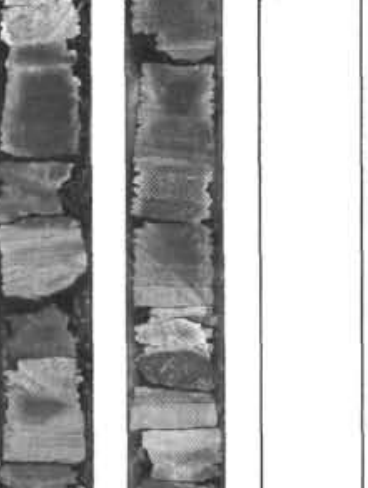

- 3

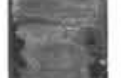

a.

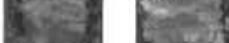

5

$5-3$

$+=$

(3)

5

$-3$

(2)

$\rightarrow-1$

5

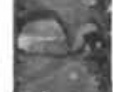

. 3

$y=-3$
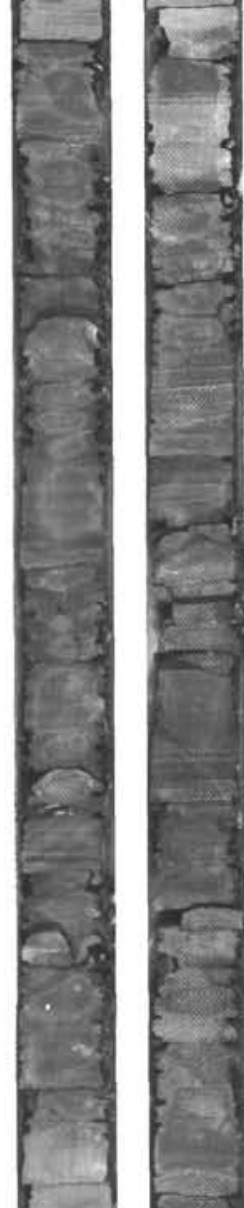

-

$-\frac{7}{4}$

$-3$

ton

s-1.

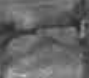

fin

Ex?
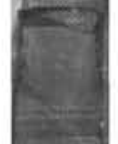

2.

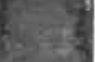

$x_{1}$

2.

z 3

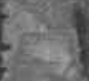

5

(1)

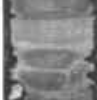

b.

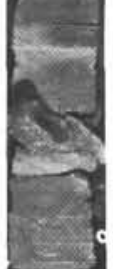

28-6

$28, \mathrm{CC}$ 


\begin{tabular}{|c|c|c|c|c|c|c|c|c|c|c|c|}
\hline & DLE 416A & & CORE & & & DRED & D INTER & VAL: & $1365.0-1375.0 \mathrm{~m}$ & & \\
\hline 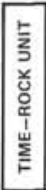 & 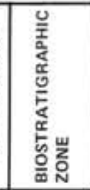 & 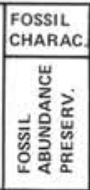 & z & 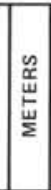 & $\begin{array}{l}\text { GRAPH } \\
\text { LITHOLC }\end{array}$ & & 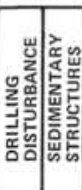 & $\begin{array}{lll}0 \\
0 \\
0 \\
0 \\
0\end{array}$ & & LITHOLOGIC DESCRIPTION & 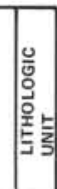 \\
\hline $\begin{array}{l} \\
z \\
\frac{2}{2} \\
\frac{2}{0} \\
\frac{2}{5} \\
\frac{1}{5} \\
>\end{array}$ & 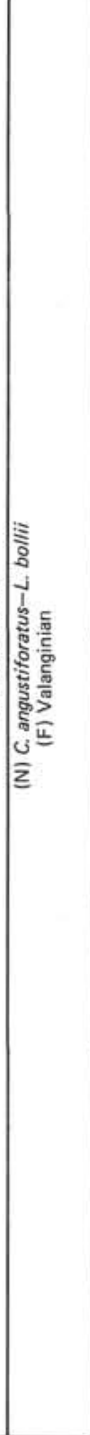 & 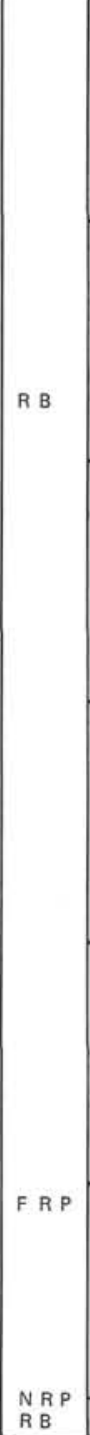 & 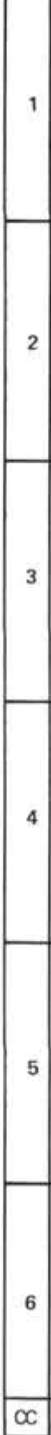 & & $\frac{1}{4}$ & $\frac{\pi}{4}$ & & 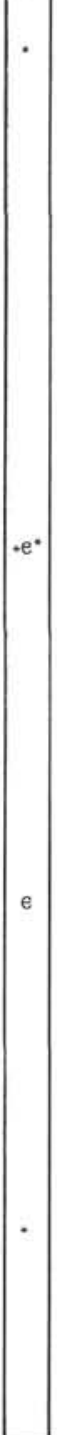 & & 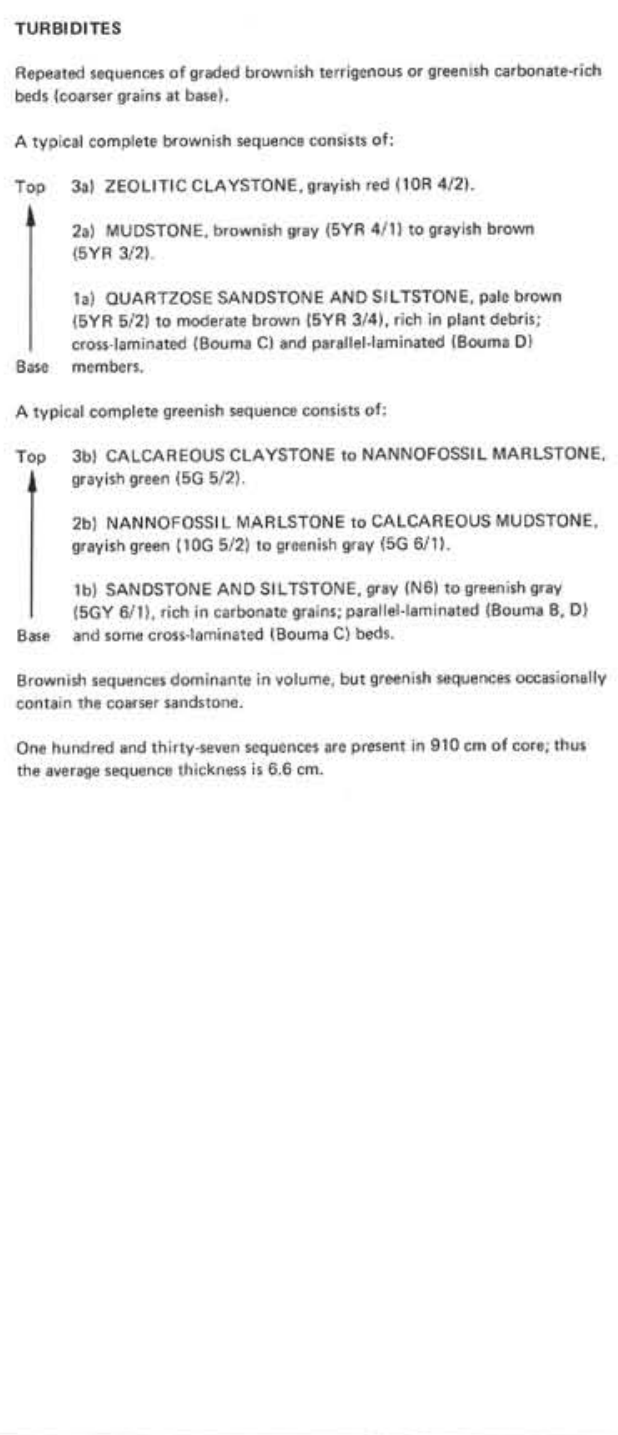 & 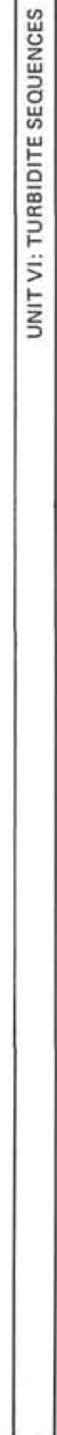 \\
\hline & $\begin{array}{l}\text { SMEAR } \\
\text { COMPOS } \\
\text { Nannofos } \\
\text { Foramini } \\
\text { Carb. uns } \\
\text { Rhombs } \\
\text { Clay } \\
\text { Quartz } \\
\text { Mica } \\
\text { Pyrite } \\
\text { Plant deb } \\
\text { Nannoco } \\
\text { TEXTUR } \\
\text { Silt } \\
\text { Clay }\end{array}$ & $\begin{array}{l}\text { SLIDES (\% } \\
\text { ITION } \\
\text { sils } \\
\text { fers } \\
\text { pec. } \\
\text { ris } \\
\text { rus } \\
\text { re } \\
\end{array}$ & $\begin{array}{c}\text { \%) } \\
1,7 \\
\text { Tr } \\
\mathrm{Tr} \\
1 \\
-95 \\
95 \\
\frac{3}{1} \\
1 \\
- \\
-10 \\
>90\end{array}$ & $\begin{array}{l}1,43 \\
T r \\
7 \\
50 \\
50 \\
- \\
1 \\
1 \\
50 \\
50\end{array}$ & $\begin{array}{l}3,48 \\
\frac{50}{5} \\
\frac{5}{40} \\
\frac{3}{-} \\
= \\
=\end{array}$ & $\begin{array}{l}3,50 \\
\frac{40}{15} \\
\frac{15}{35} \\
\frac{4}{2} \\
\frac{2}{3}\end{array}$ & $\begin{array}{c}\frac{6,27}{3} \\
\frac{7}{\mathrm{Tr}} \\
90 \\
5 \\
5 \\
1 \\
\frac{1}{-} \\
10 \\
90\end{array}$ & & \begin{tabular}{lcc}
\multicolumn{4}{c}{ CARBON-CARBONATE $(\%)$} \\
& 3,49 & 4,120 \\
$\mathrm{CaCO}_{3}$ & 64 & 13 \\
Organic carbon & 0.3 & 0.3 \\
Total carbon & 8.0 & 1.8
\end{tabular} & . & \\
\hline
\end{tabular}


Hole 416A

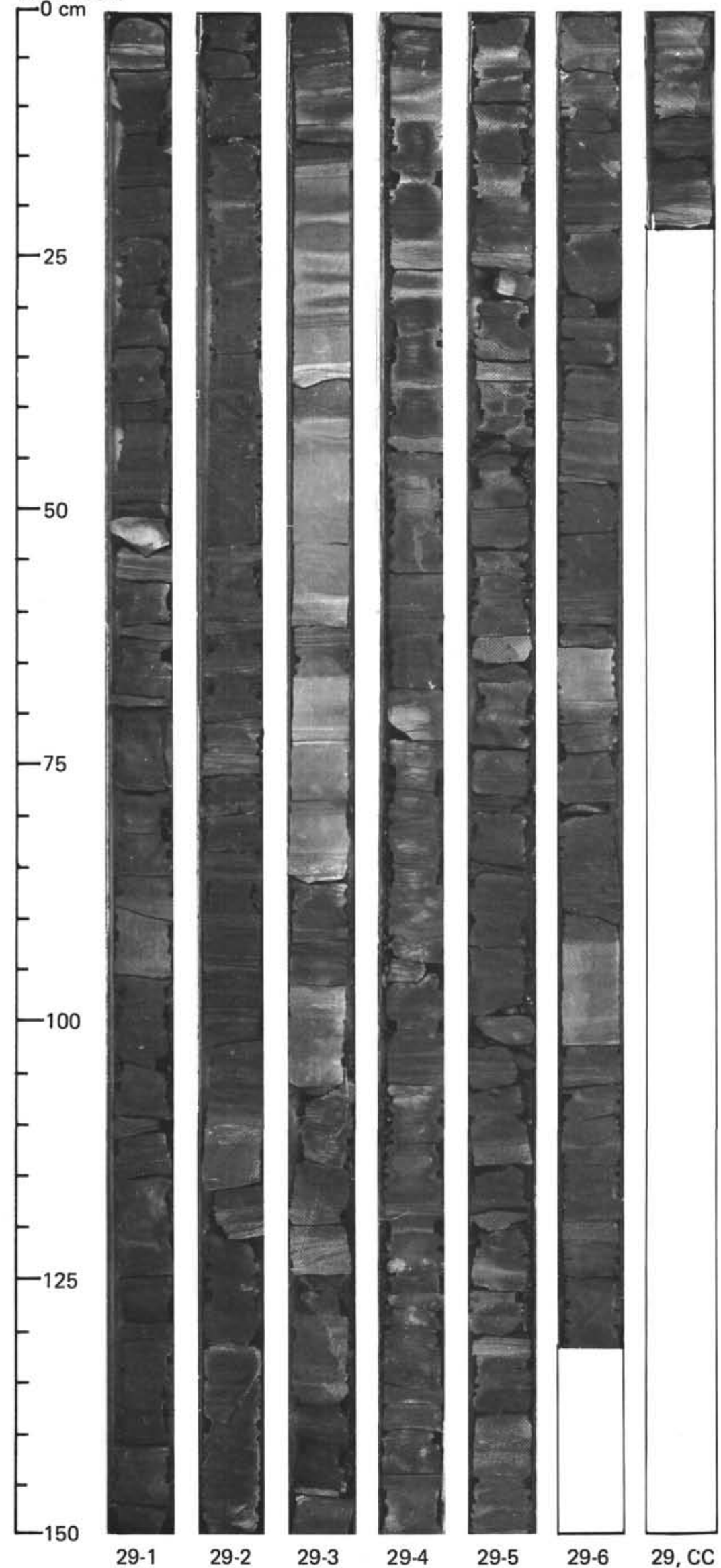


HOLE 416A CORE 30 CORED INTERVAL: $1375.0-1384.0 \mathrm{~m}$

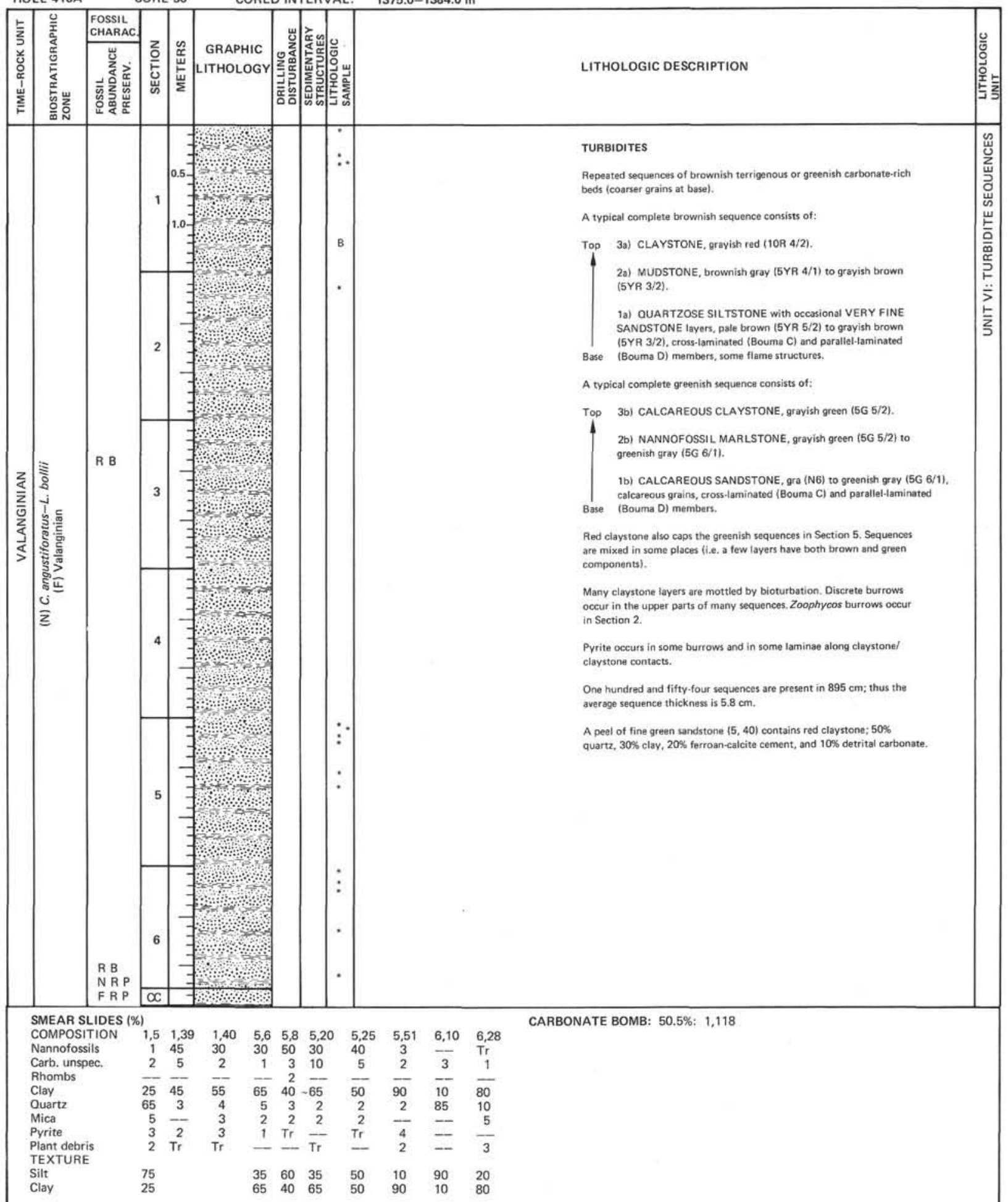


Hole 416A

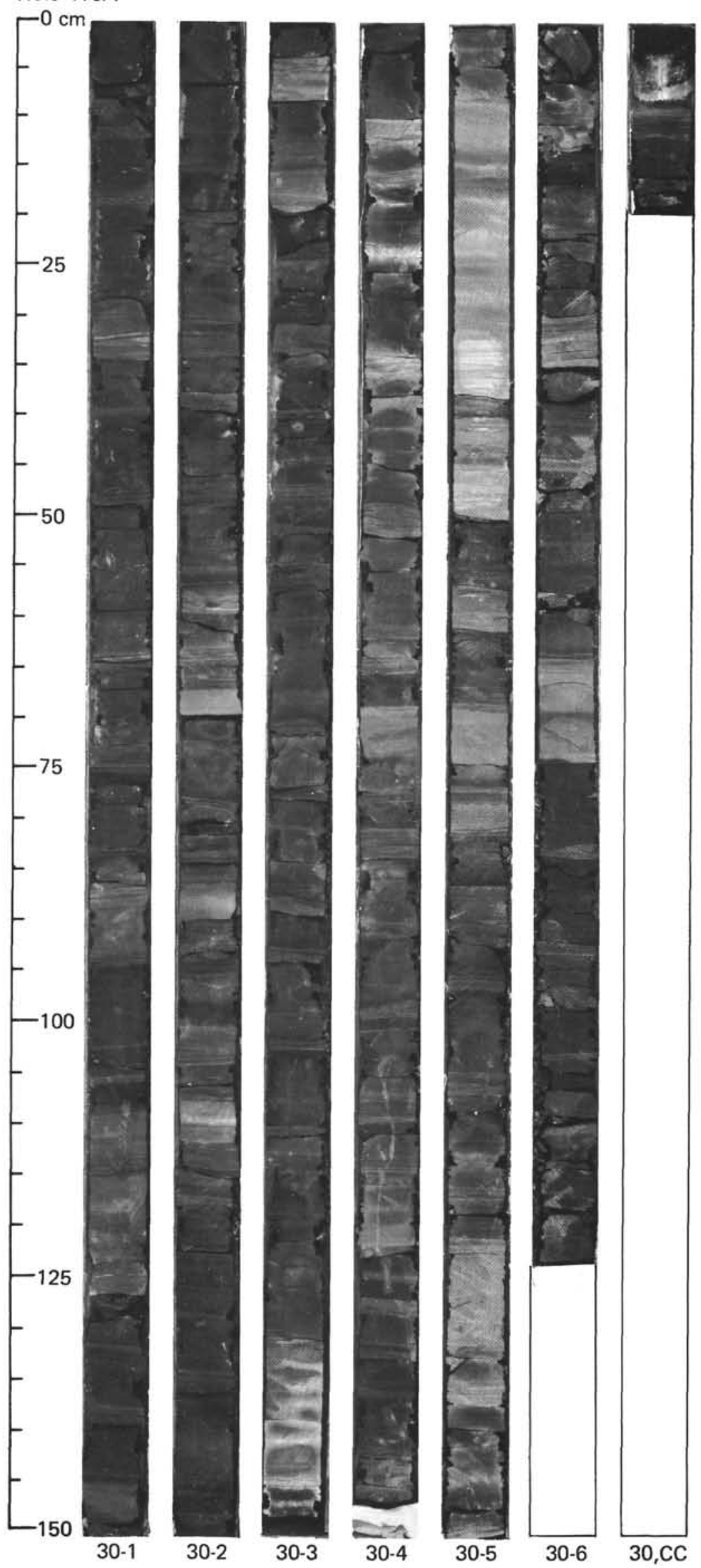




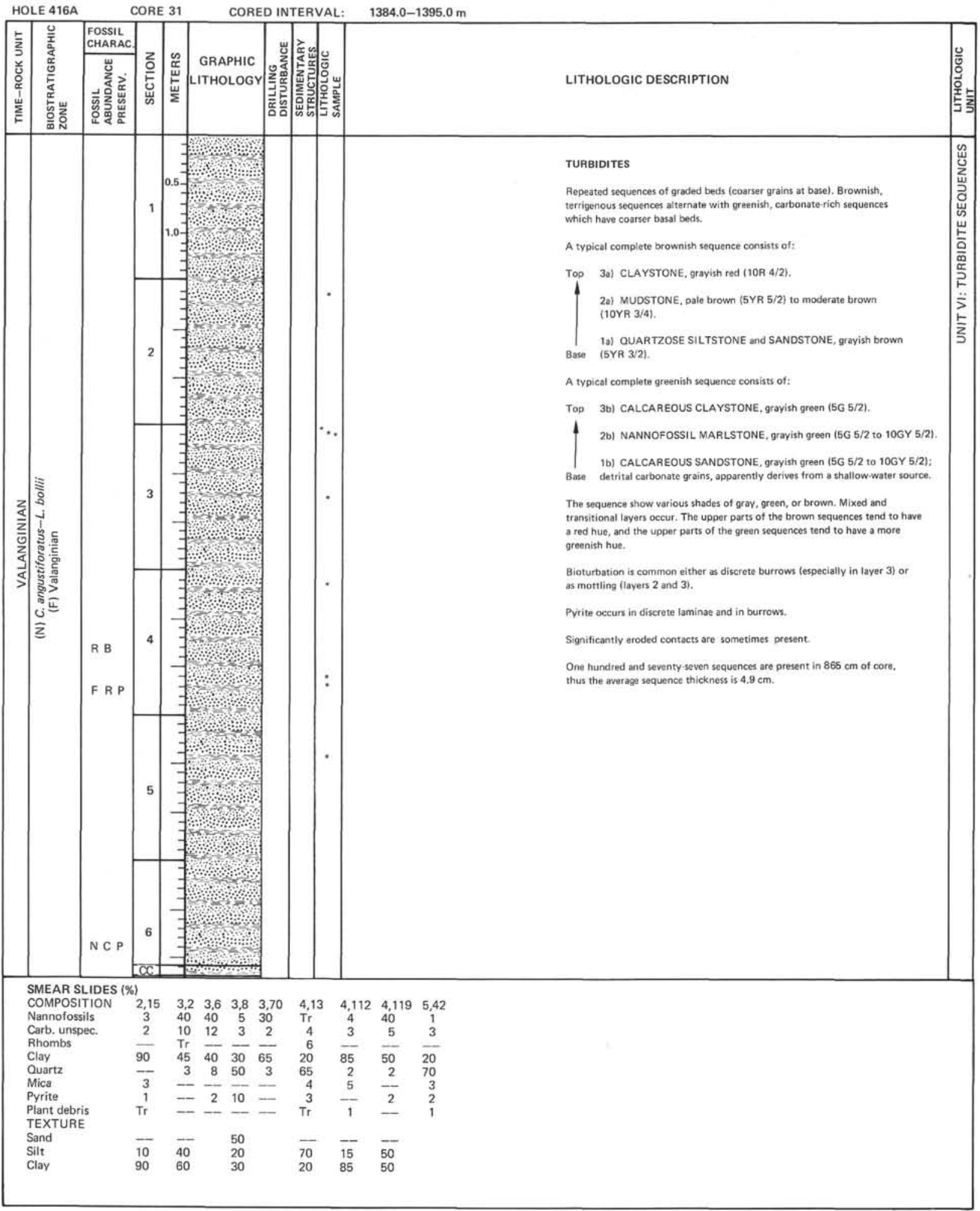


Hole 416A

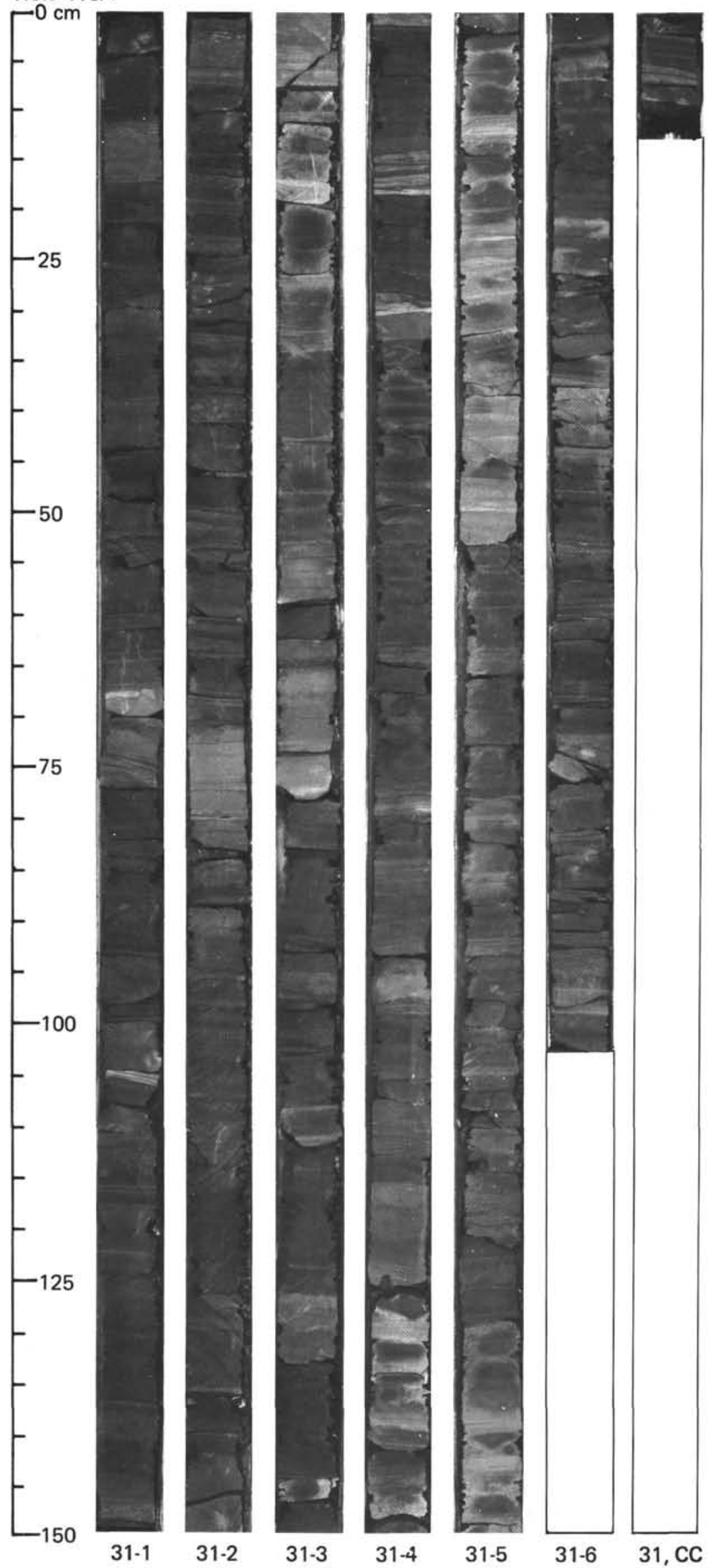




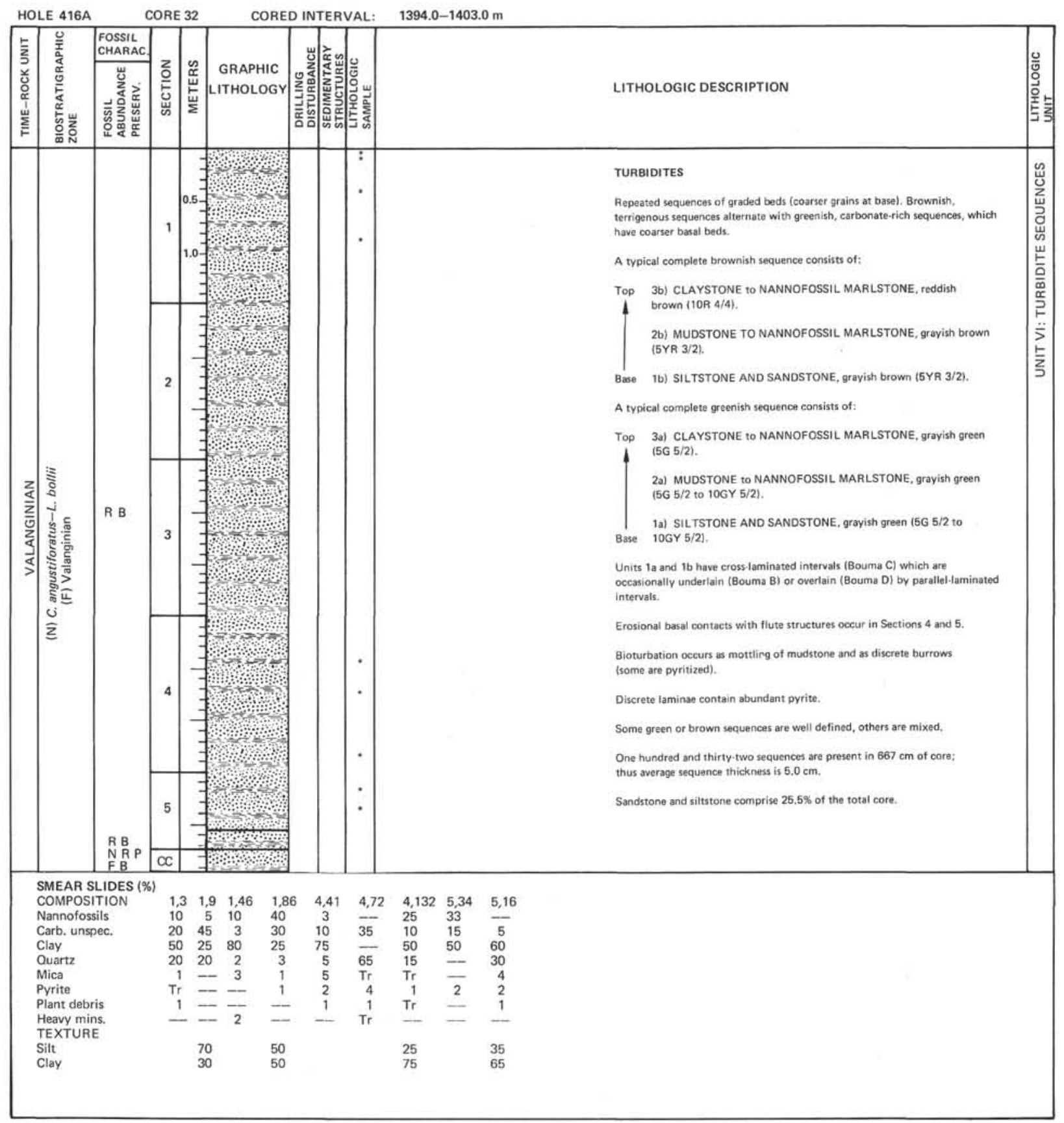


Hole 416A

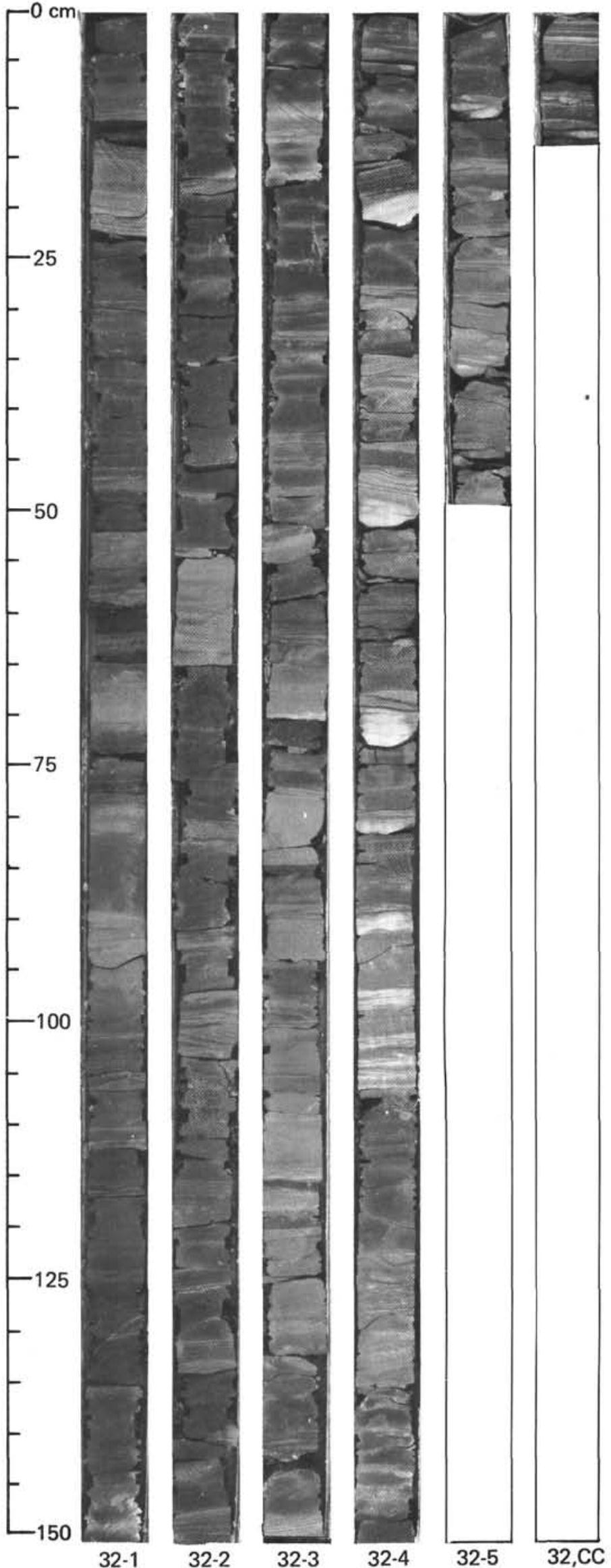




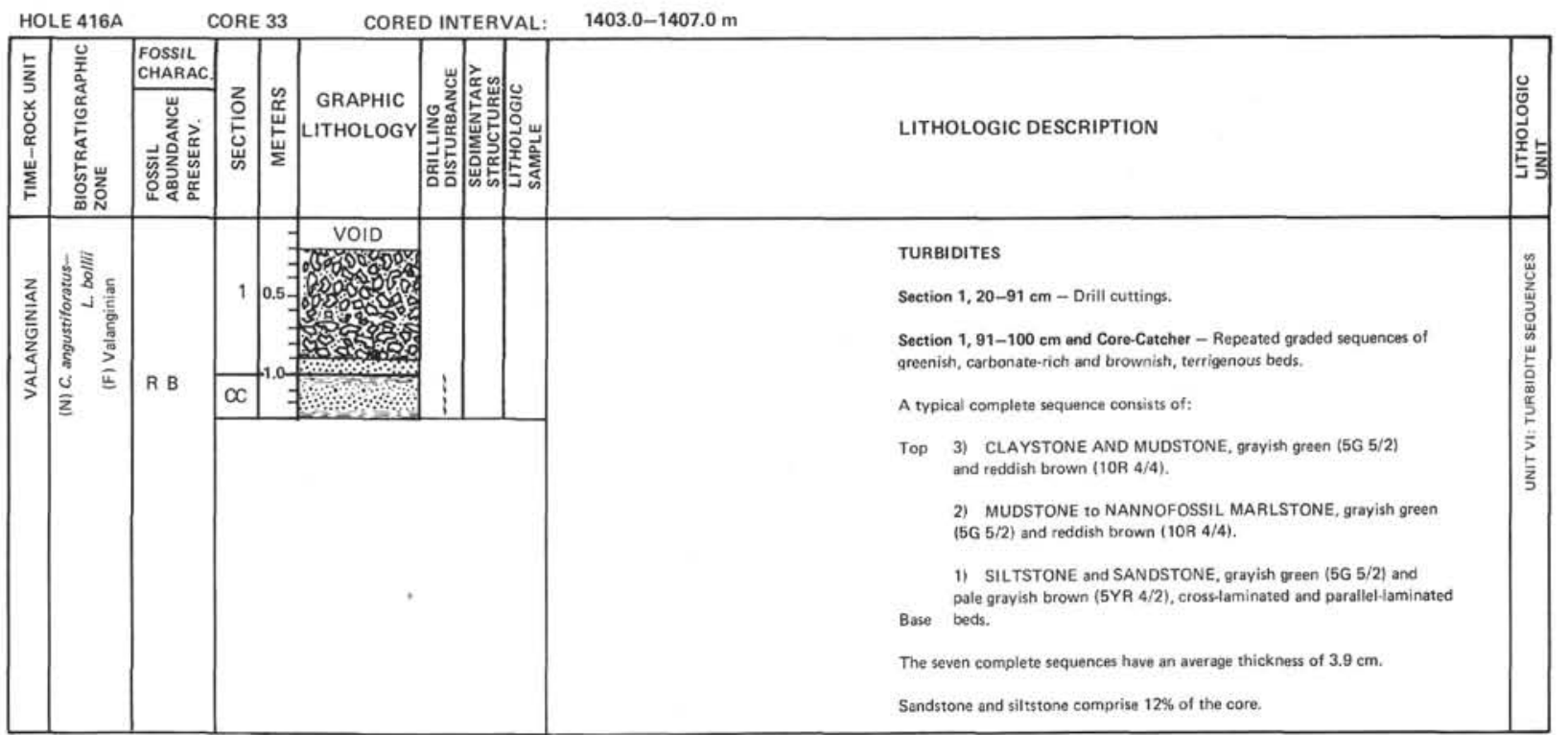

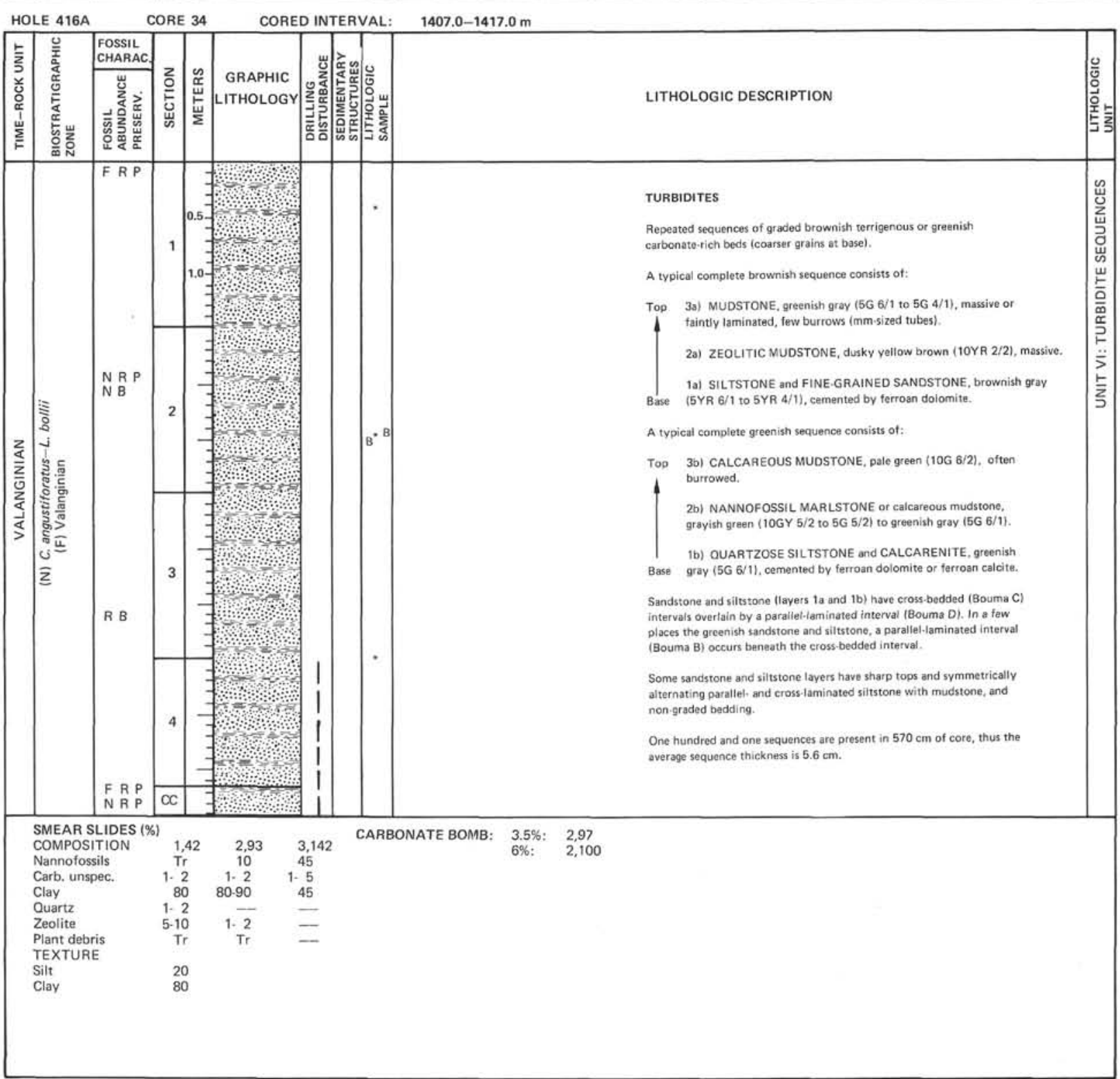


Hole 416A

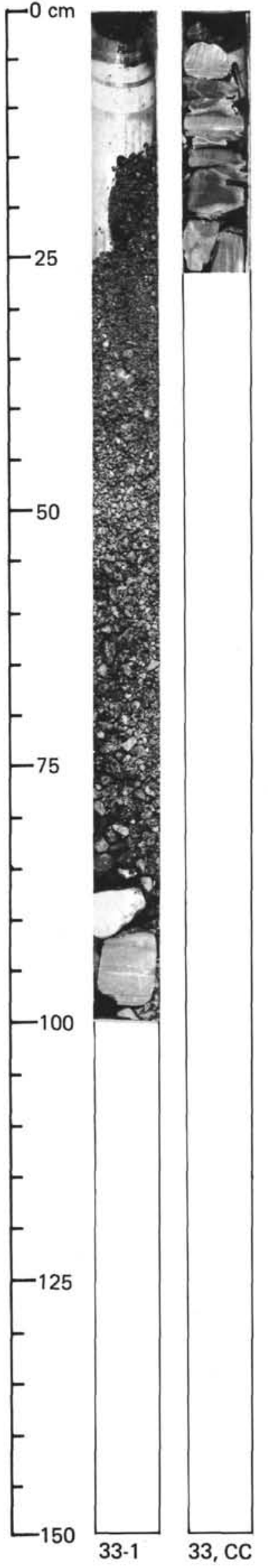

Hole 416A

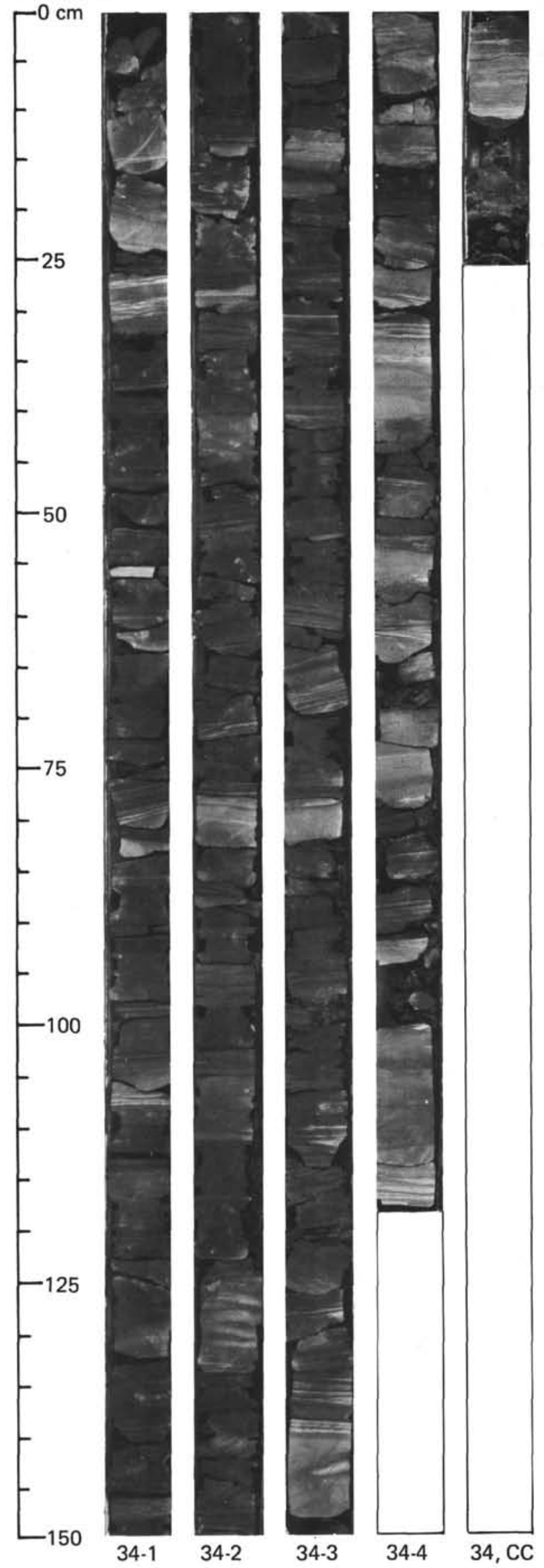




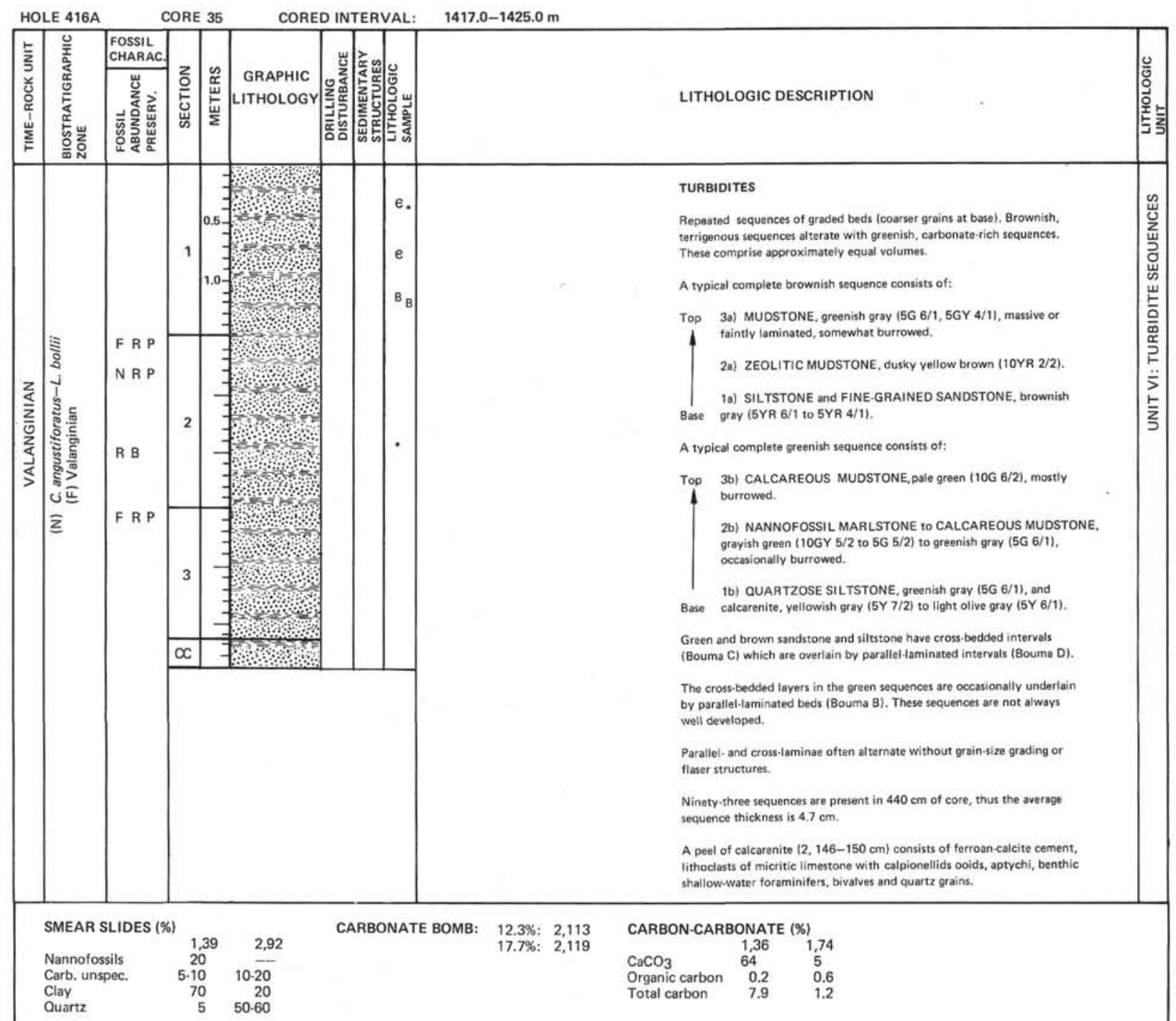




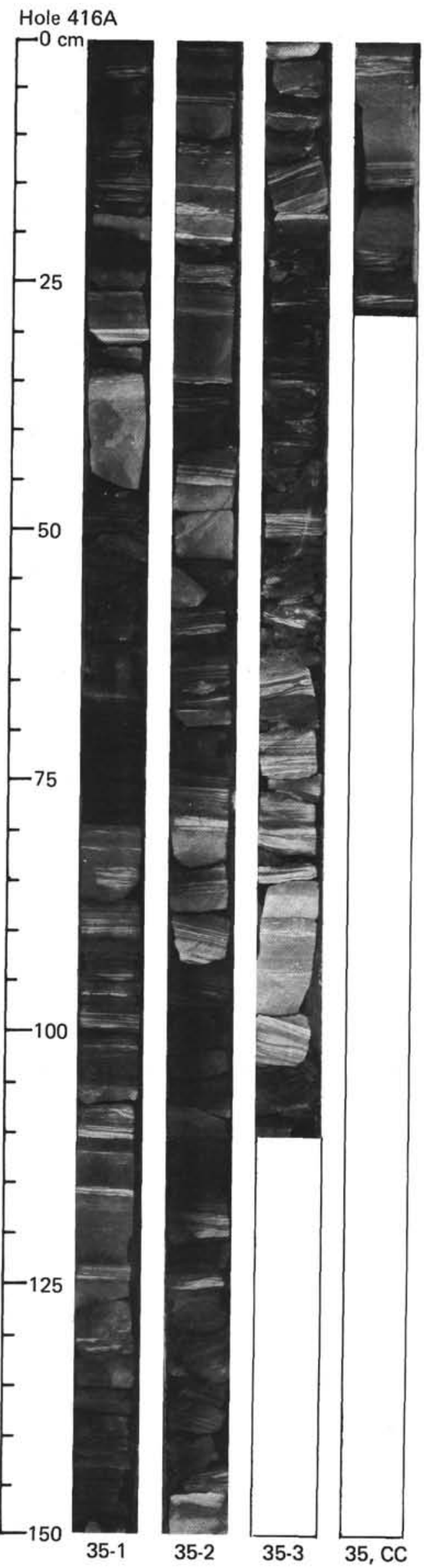




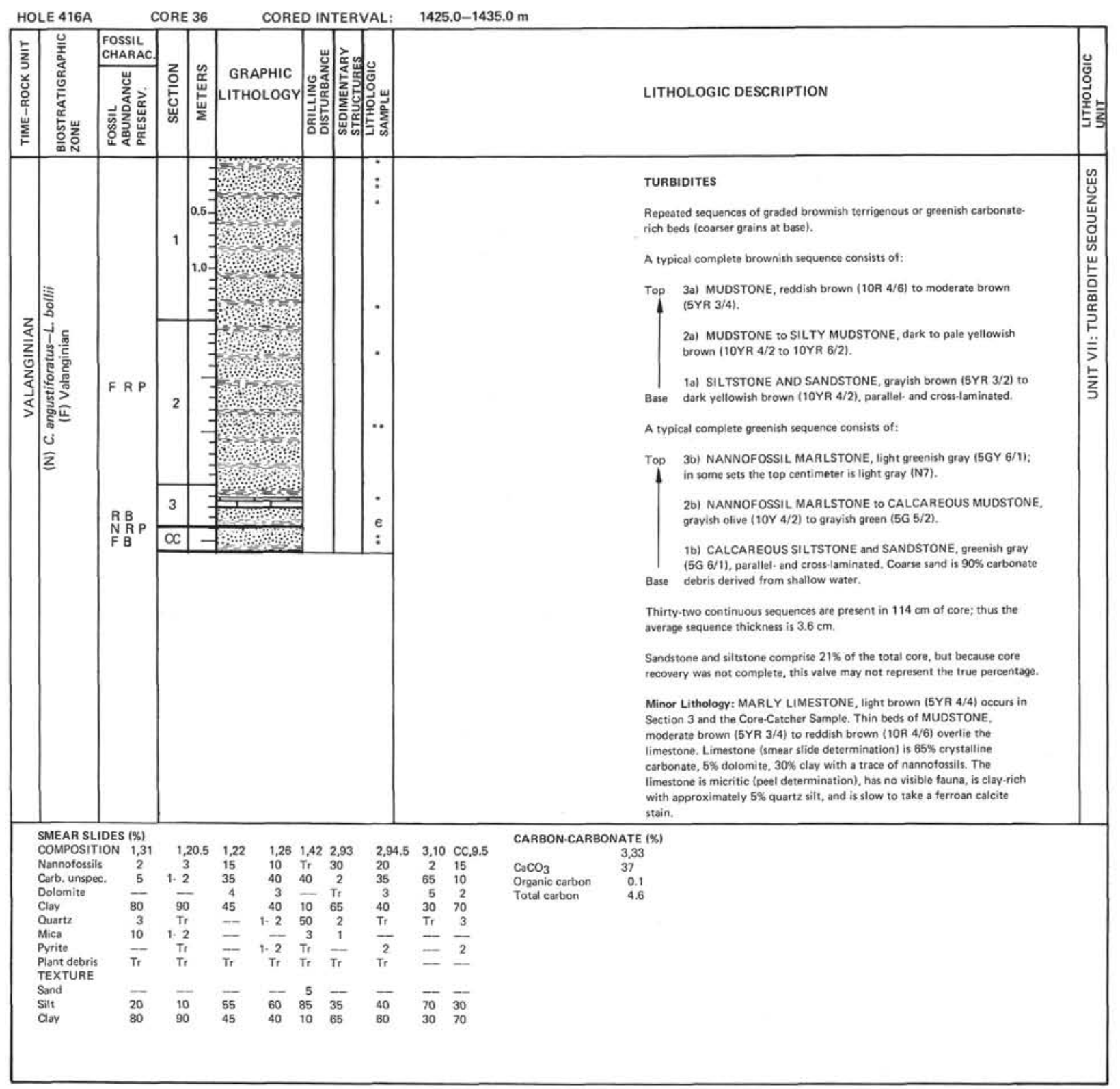


Hole 416A

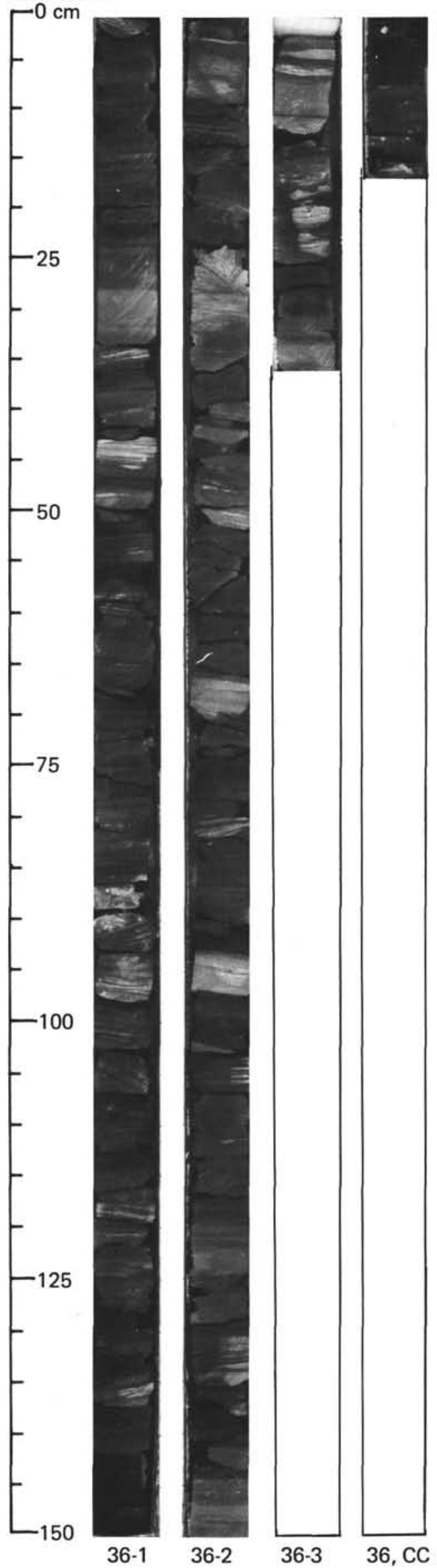


SITE 416

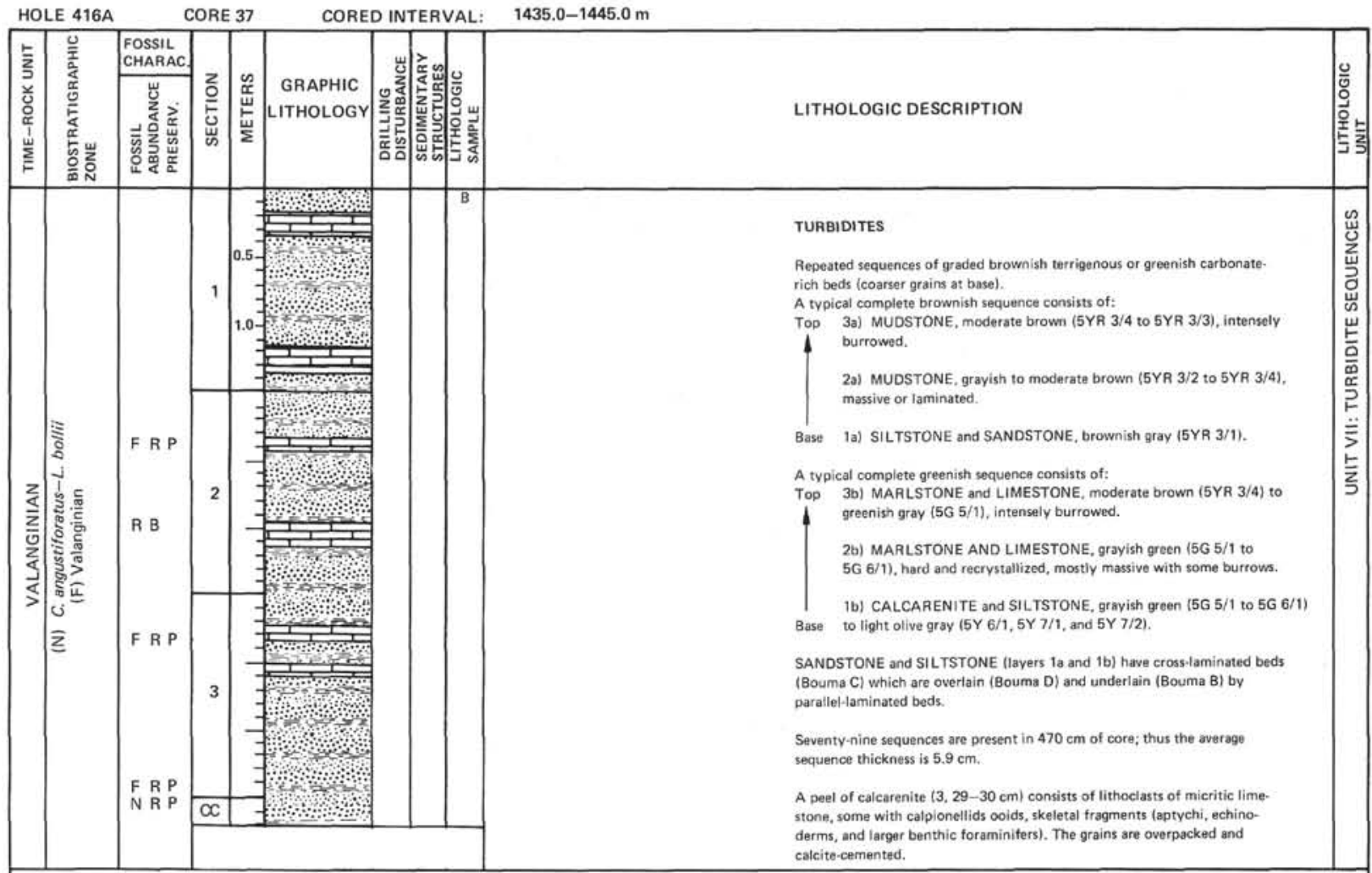

CARBONATE BOMB: $5 \%: 1,7$ 


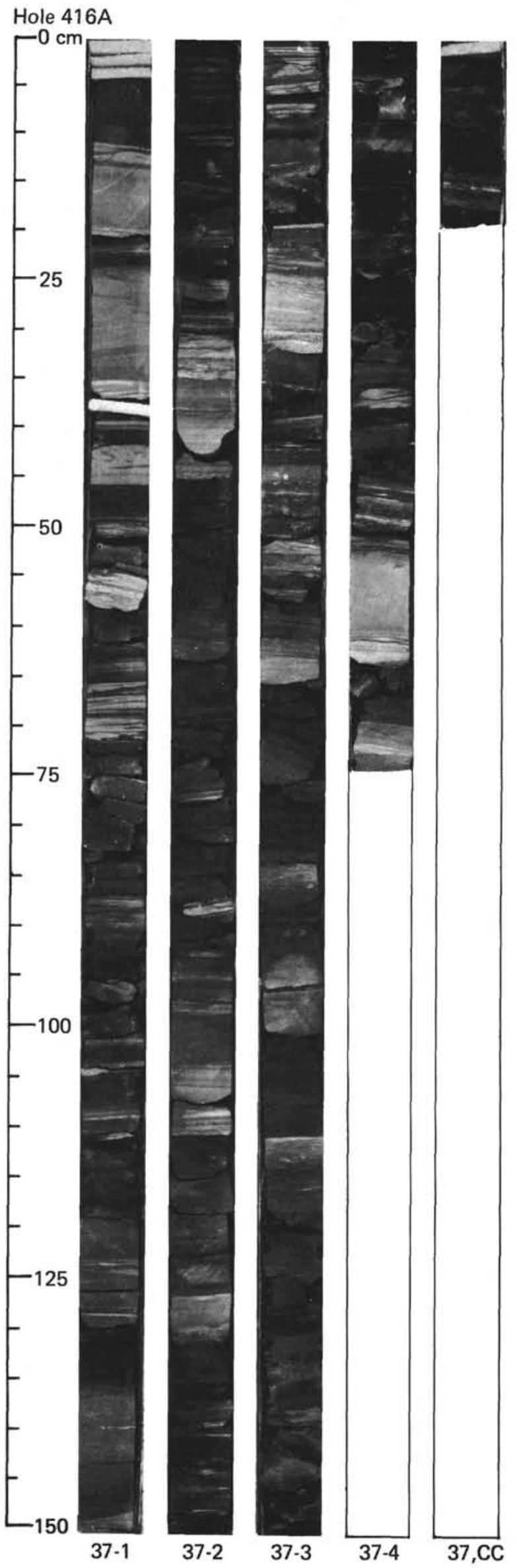




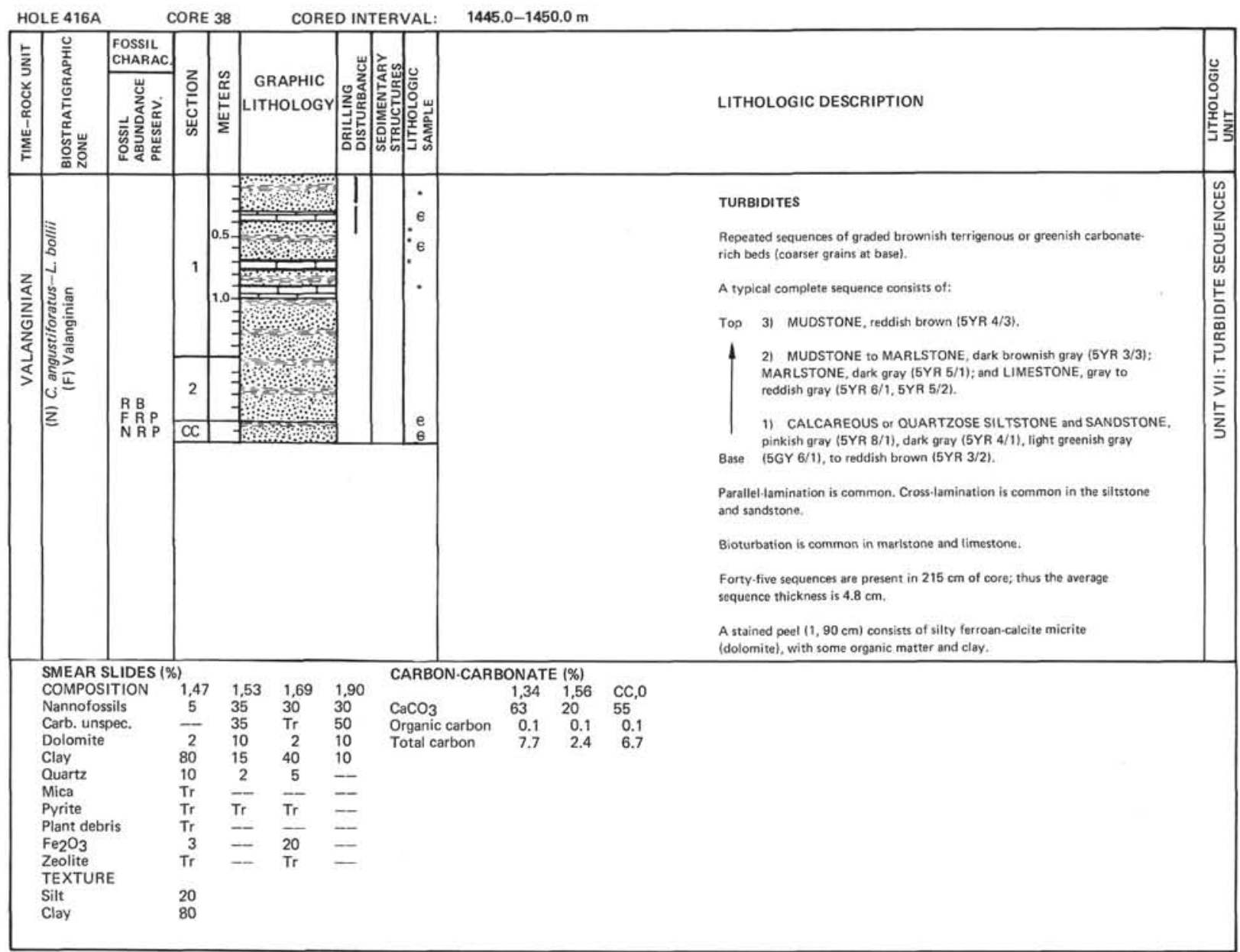

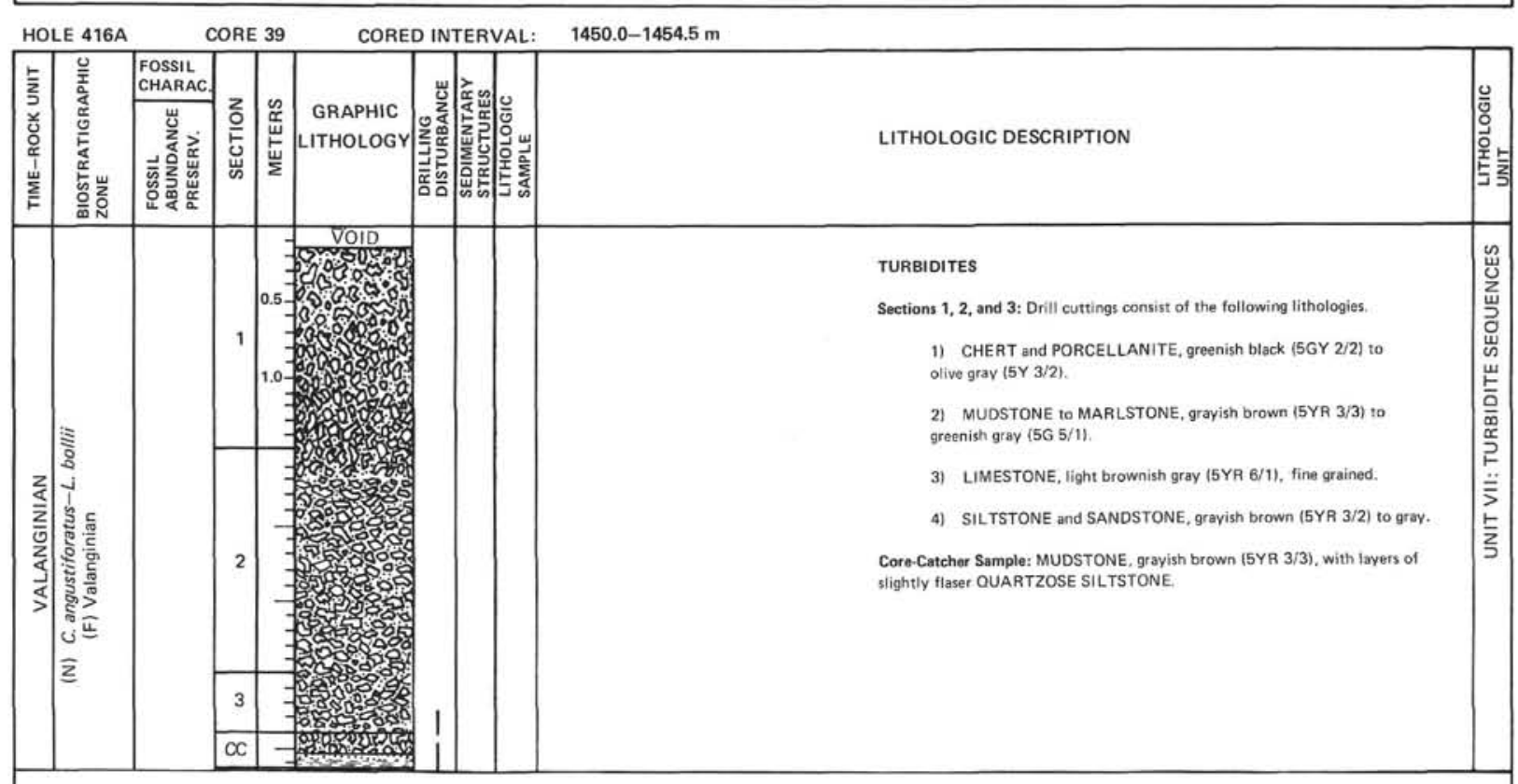


Hole 416A

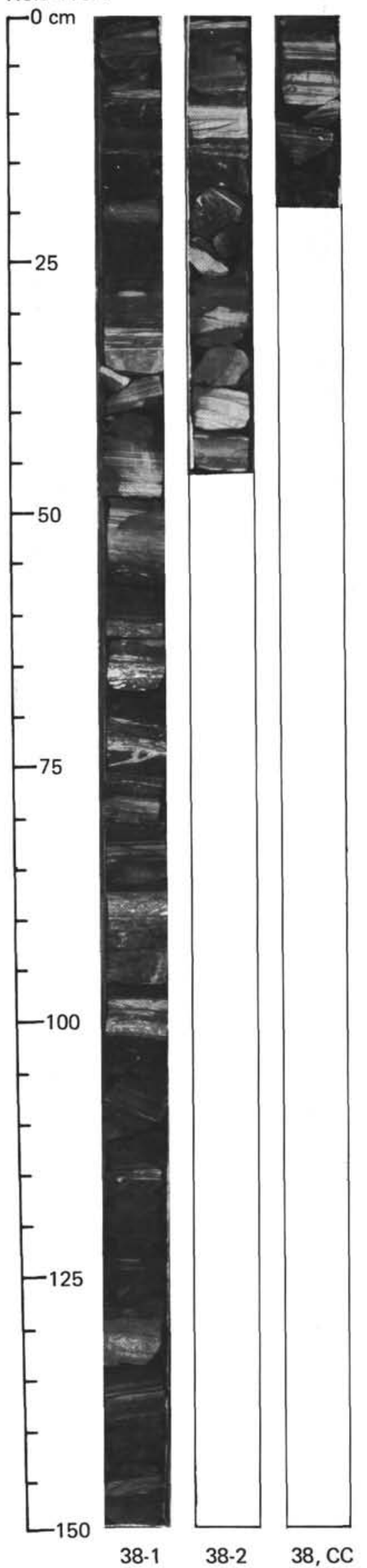

Hole 416A

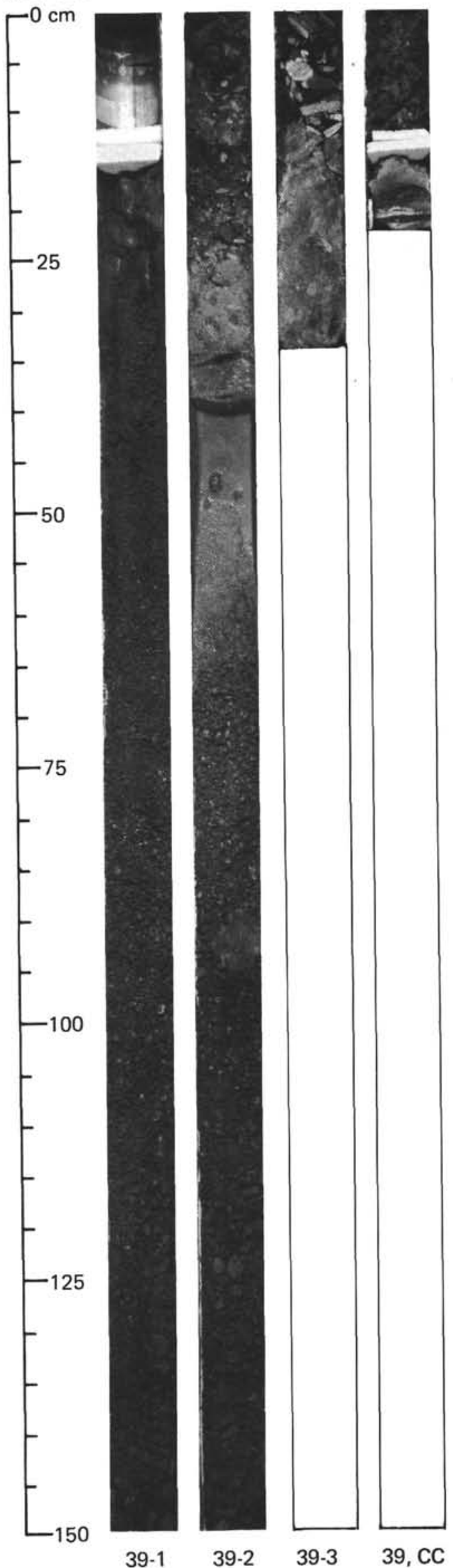




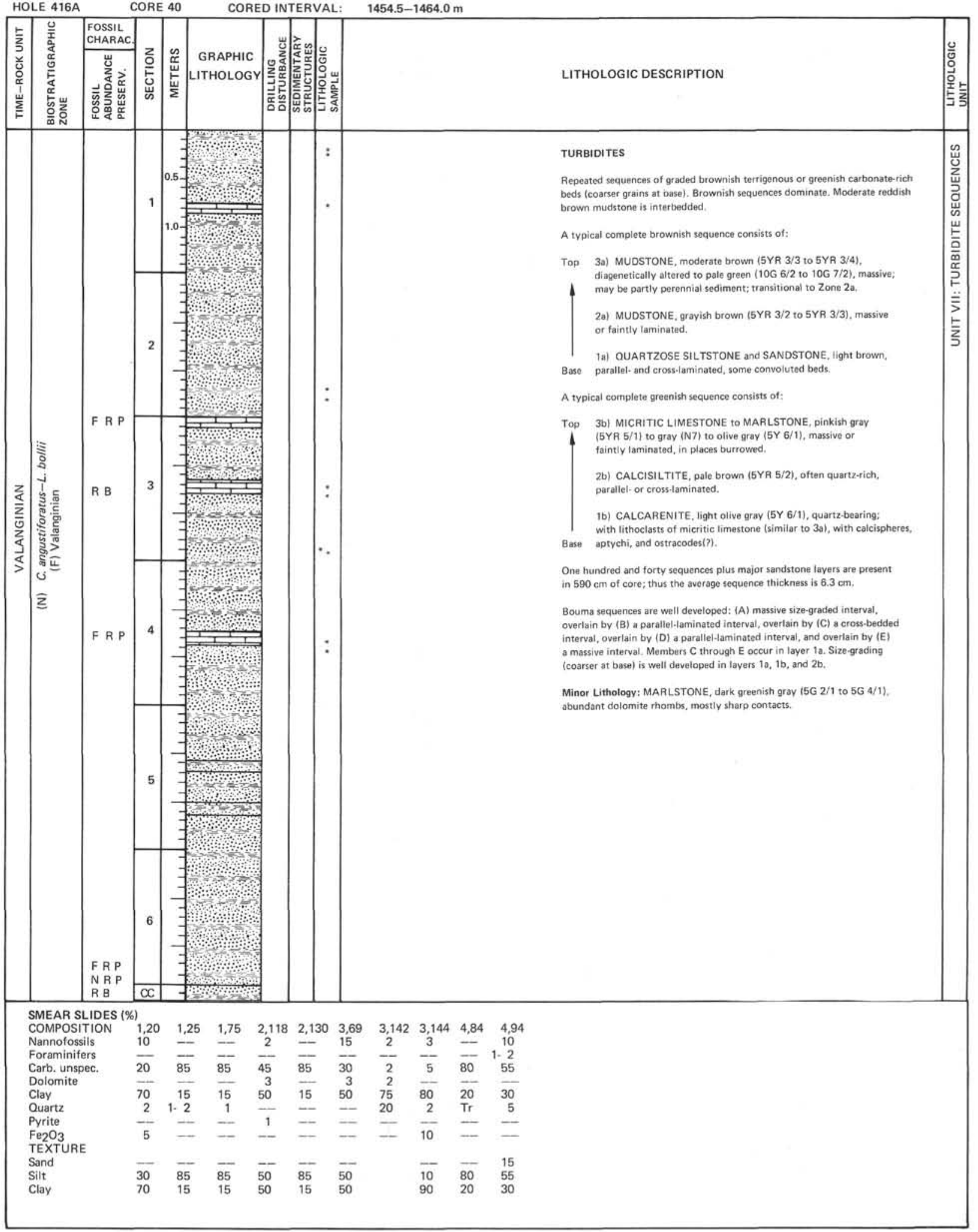


Hole 416A

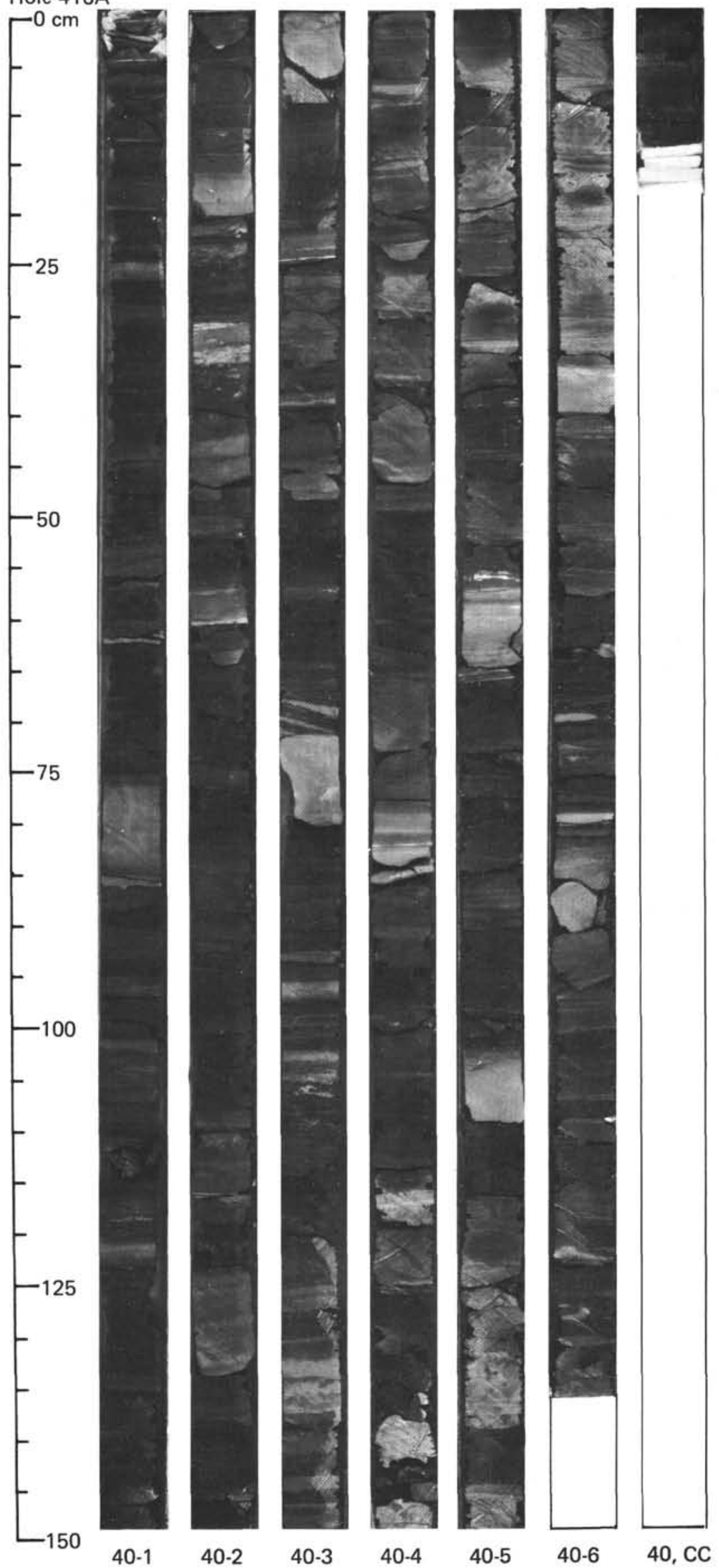




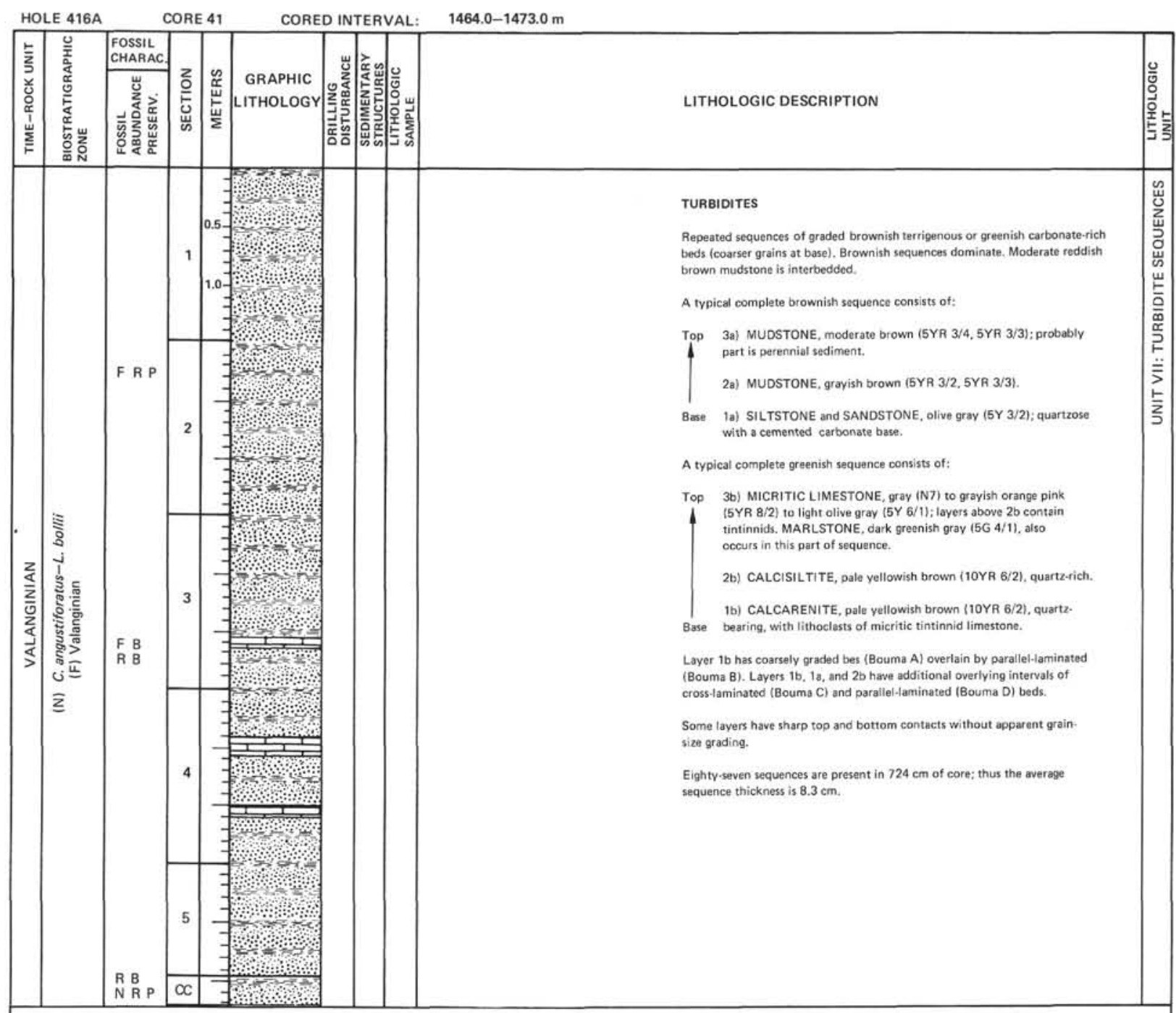


Hole 416A

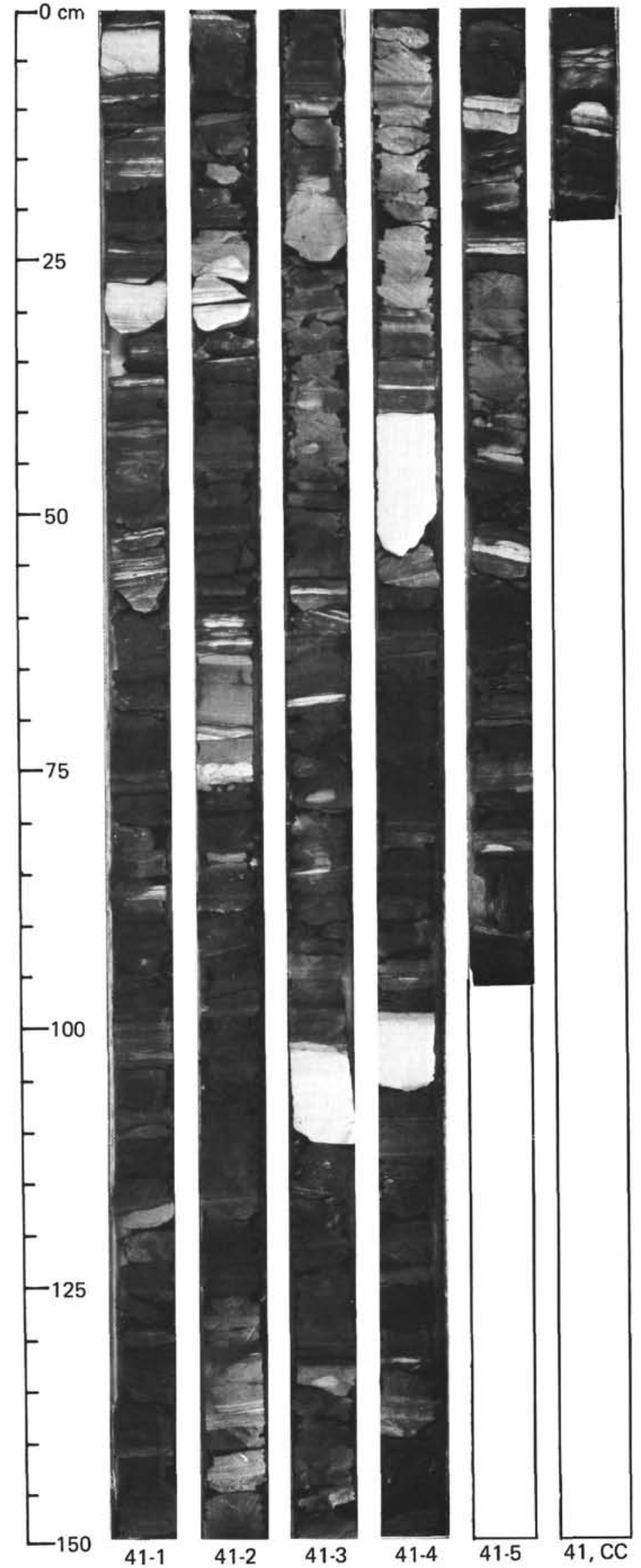




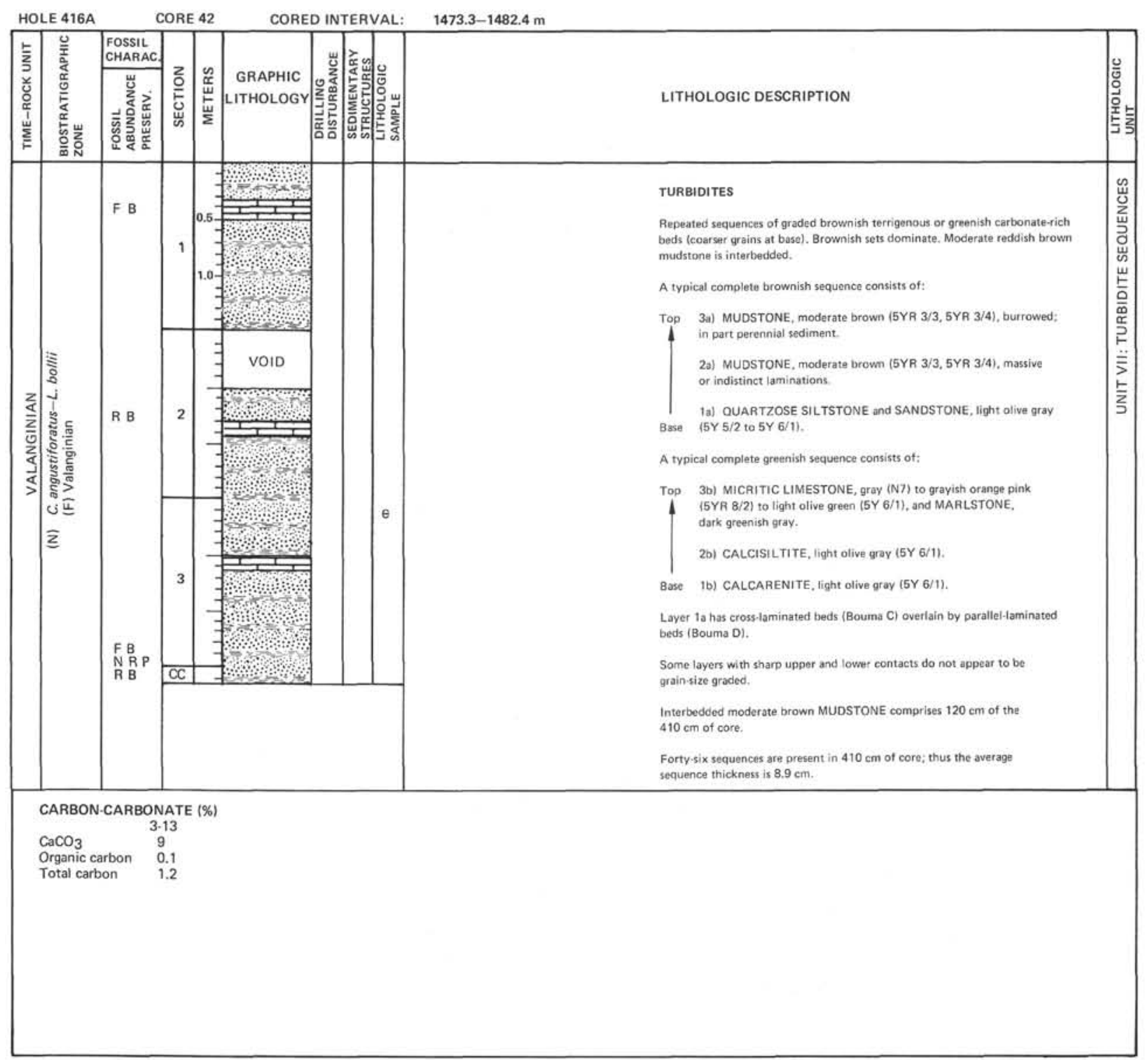


Hole 416A

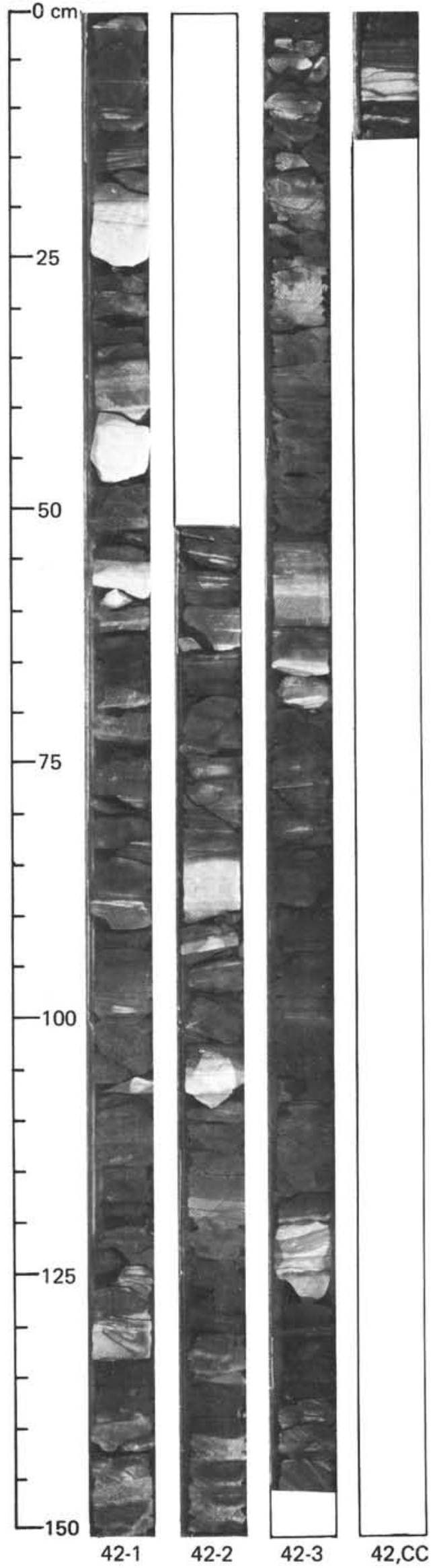




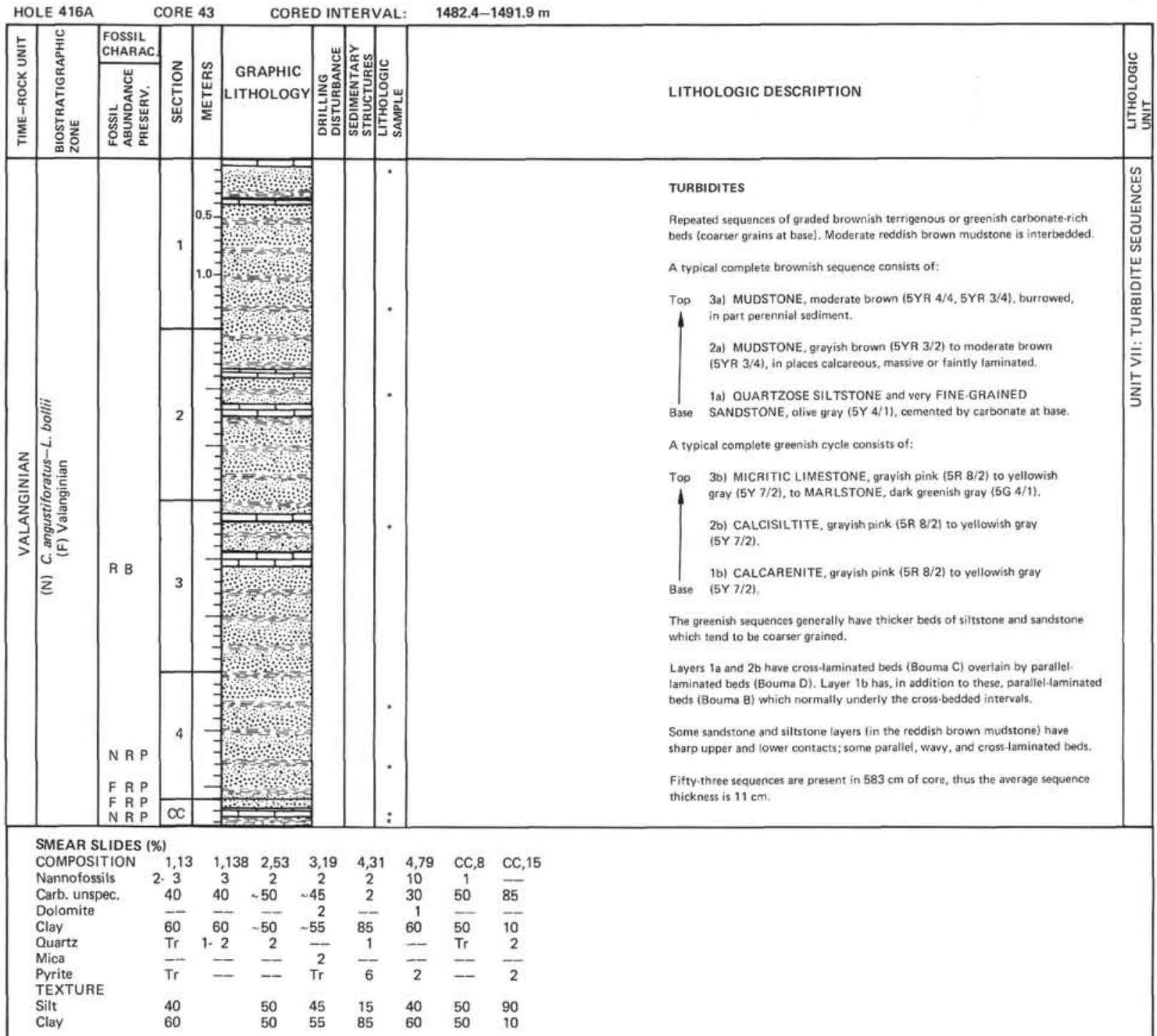


Hole 416A

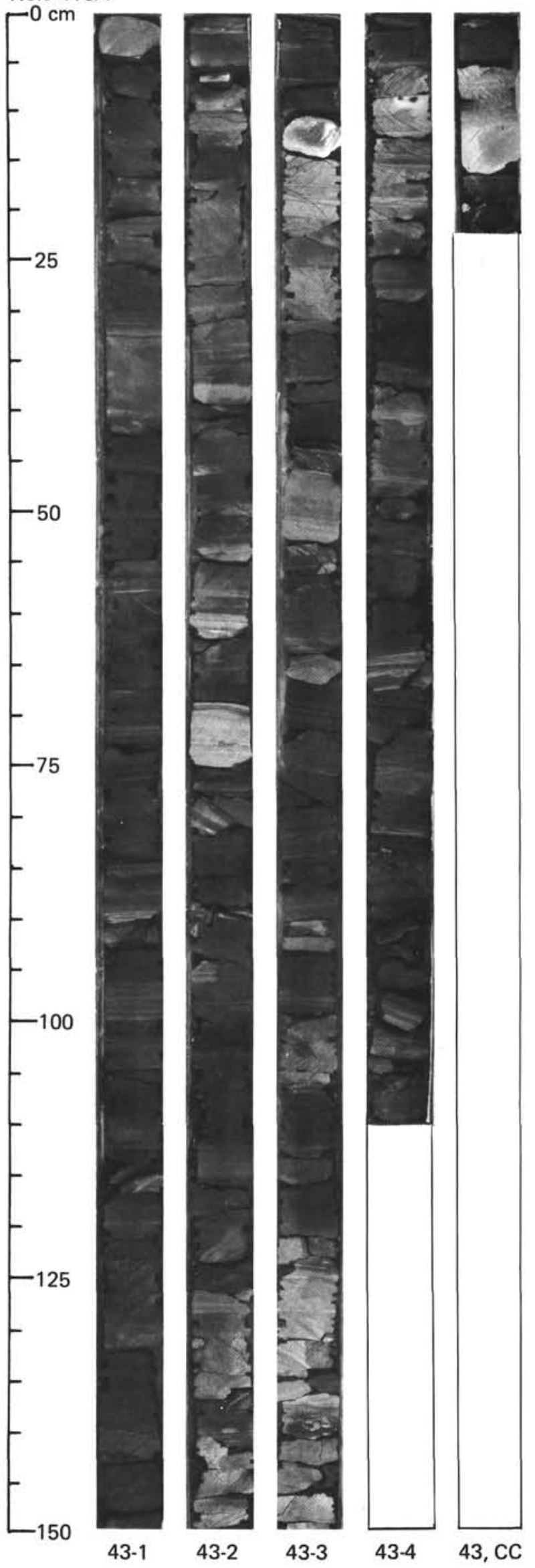




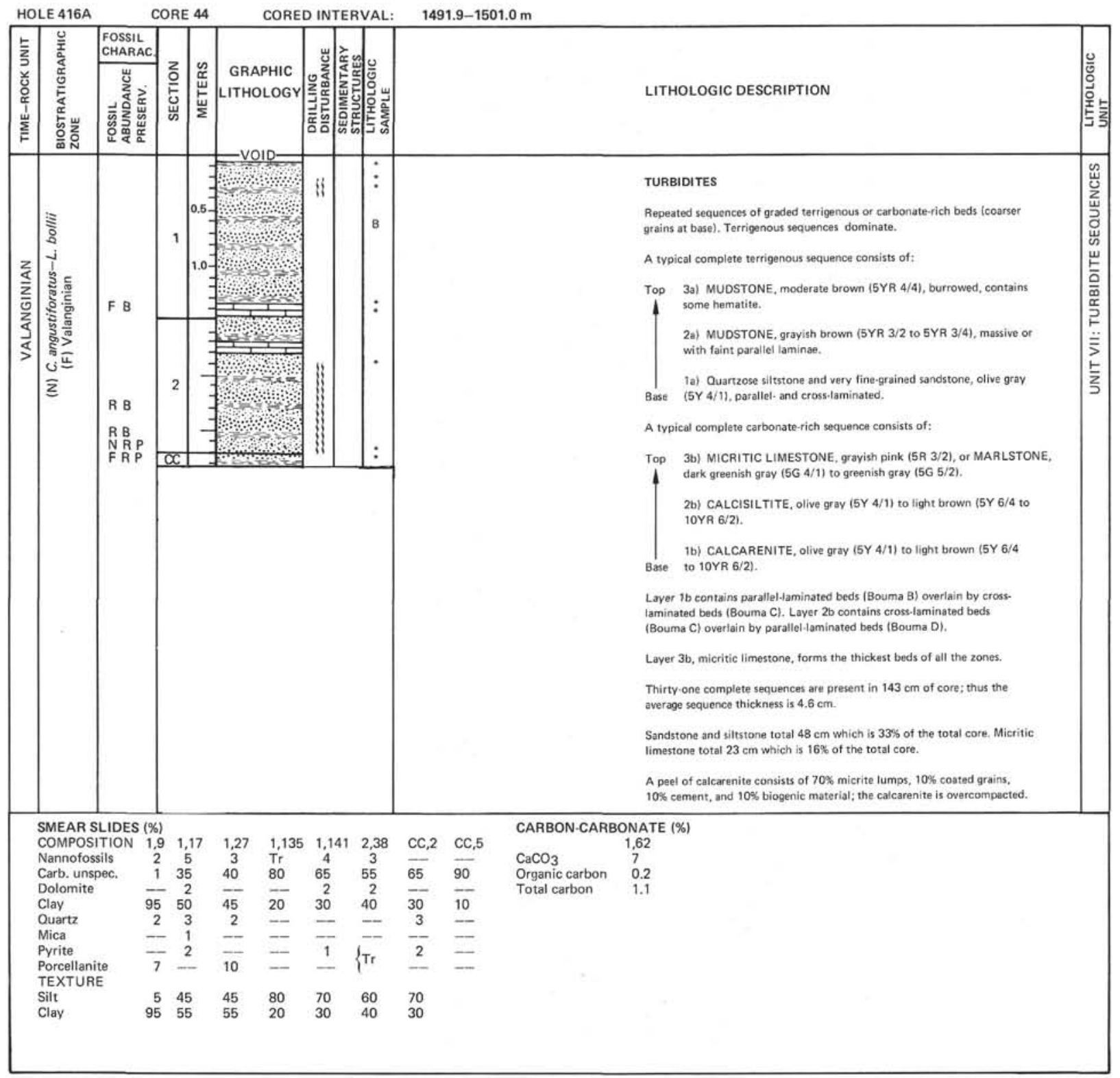




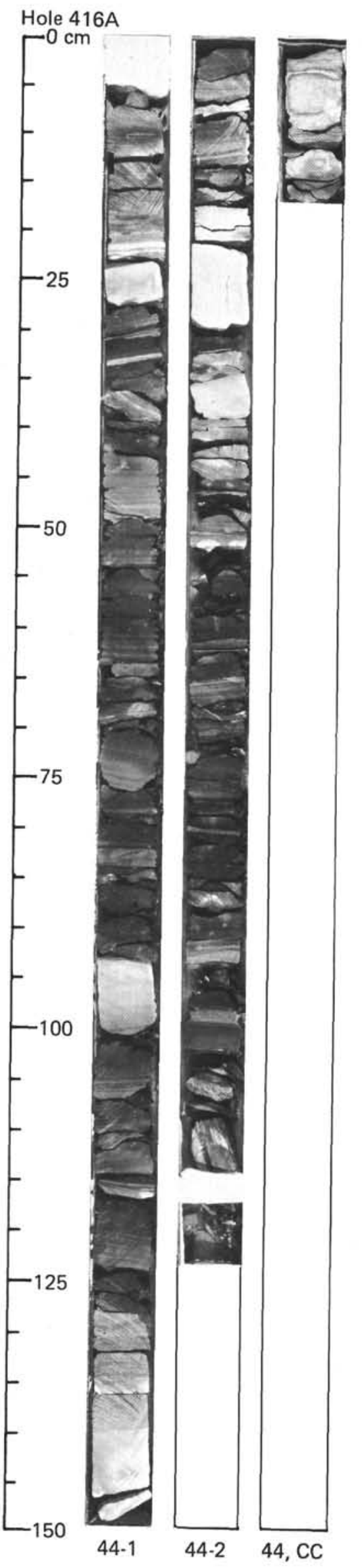




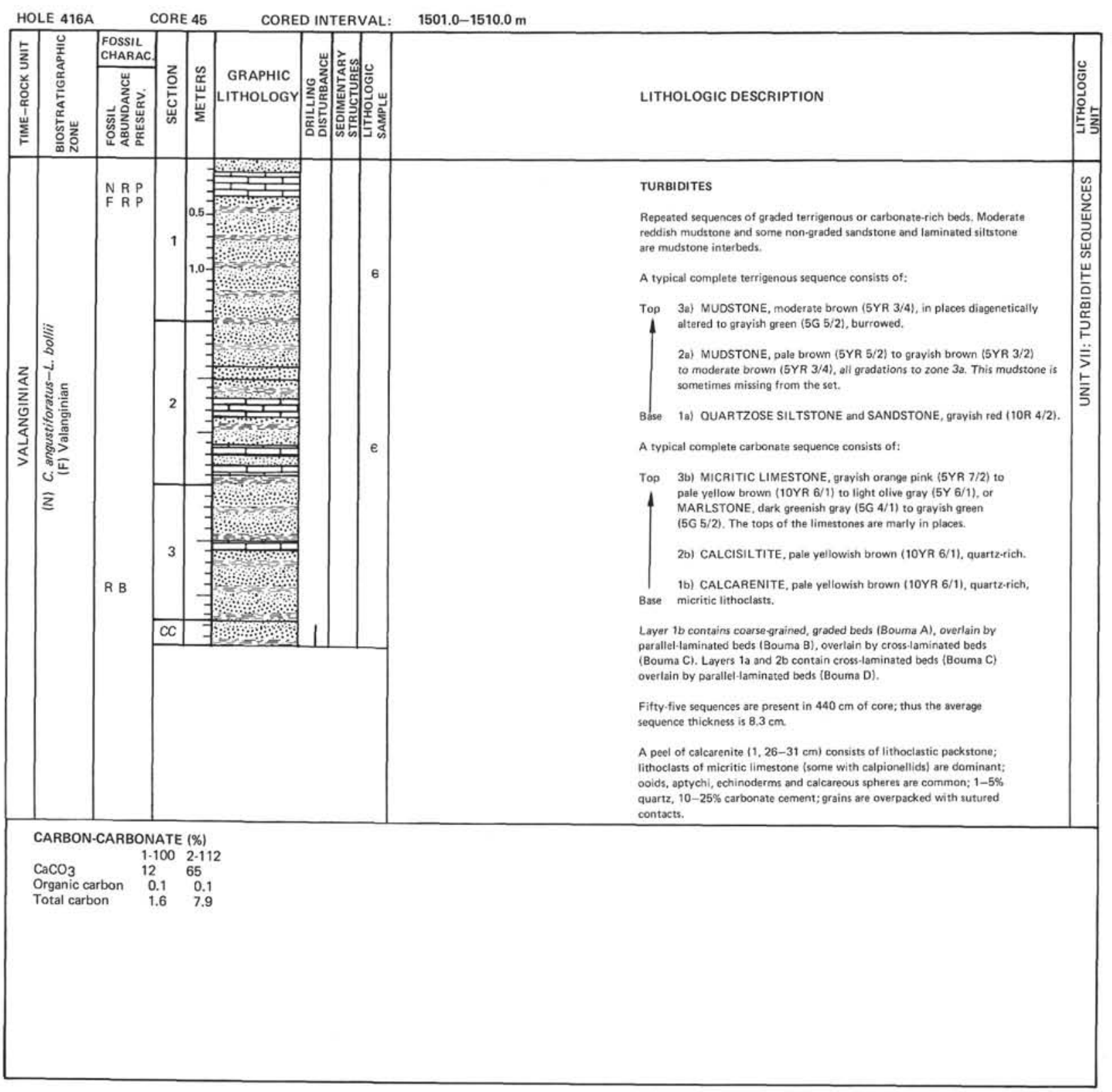


Hole 416A

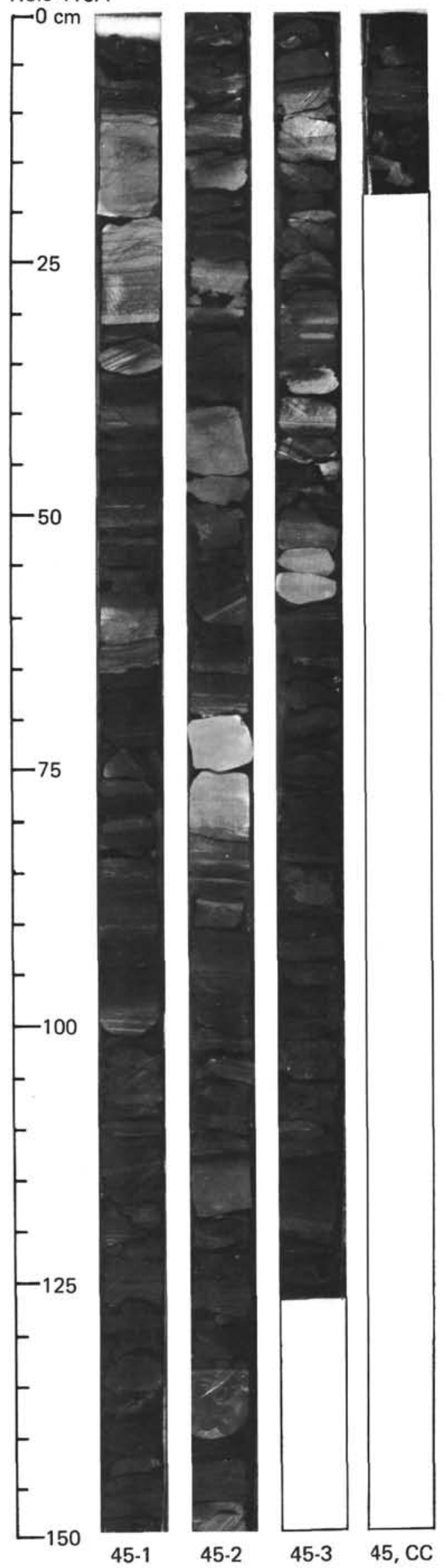




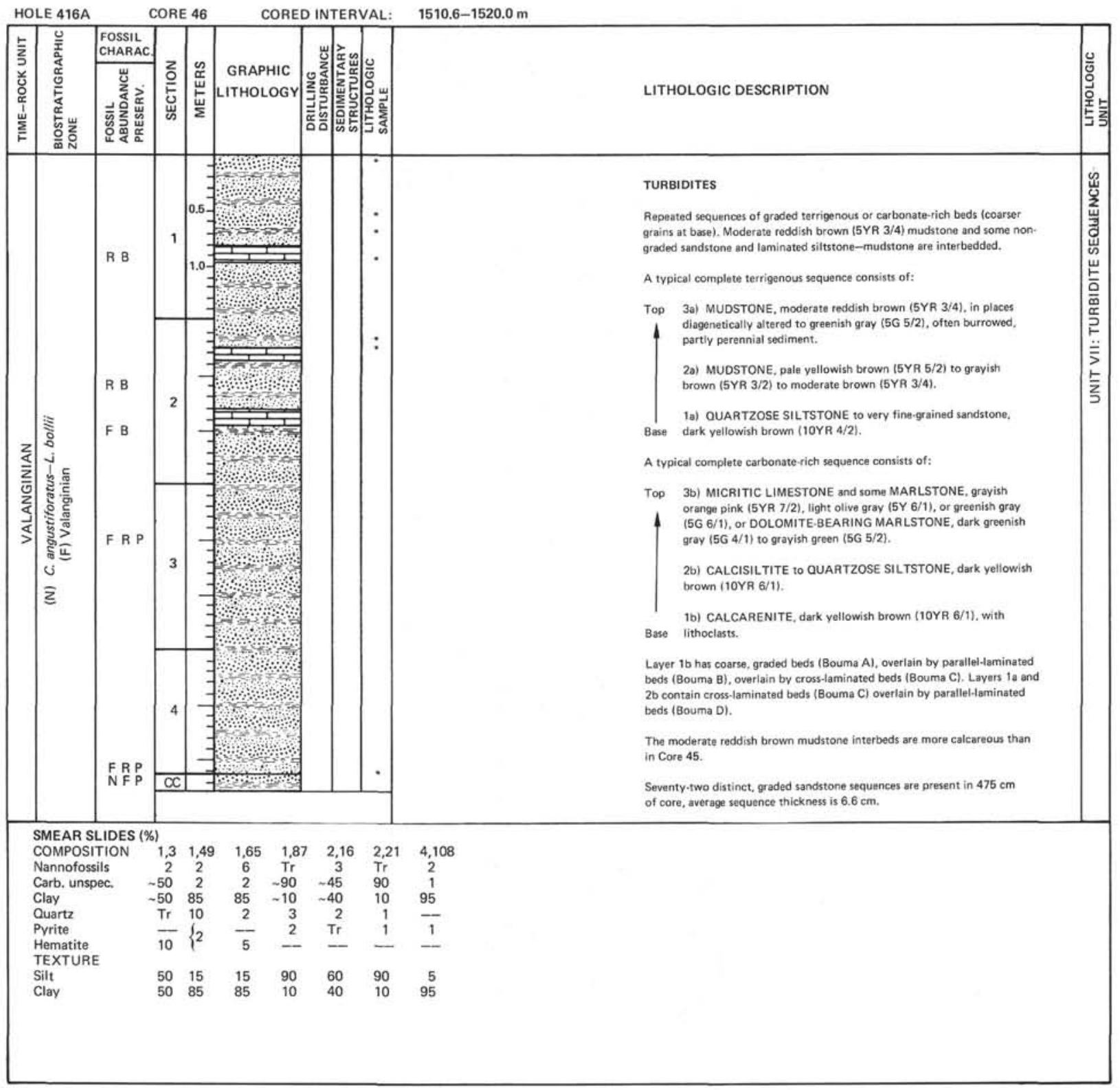


Hole 416A

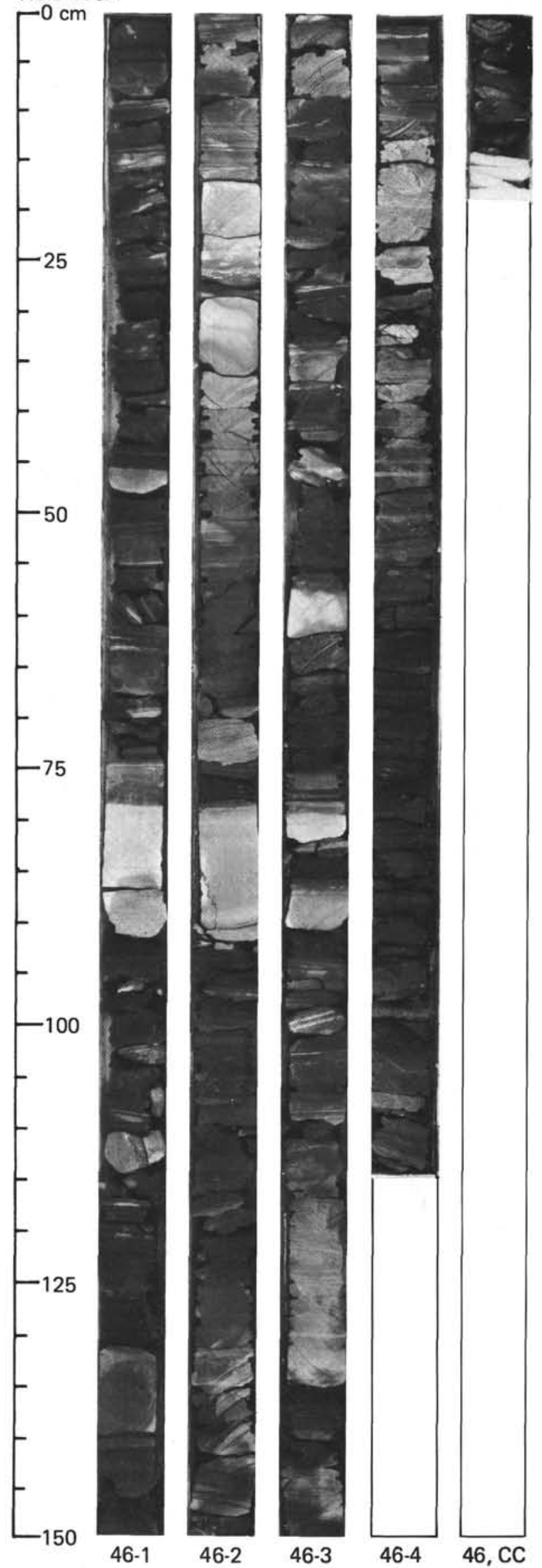




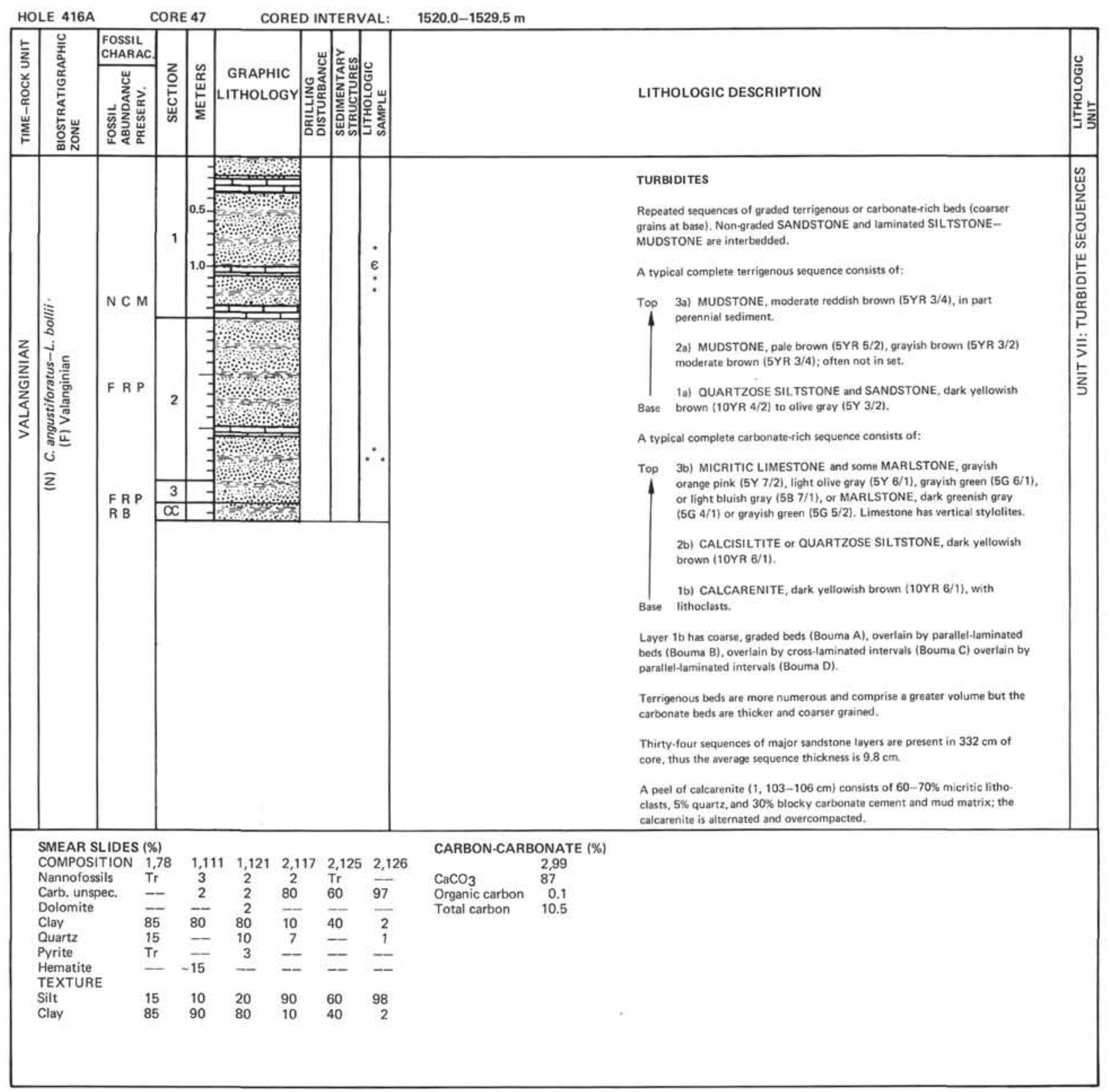




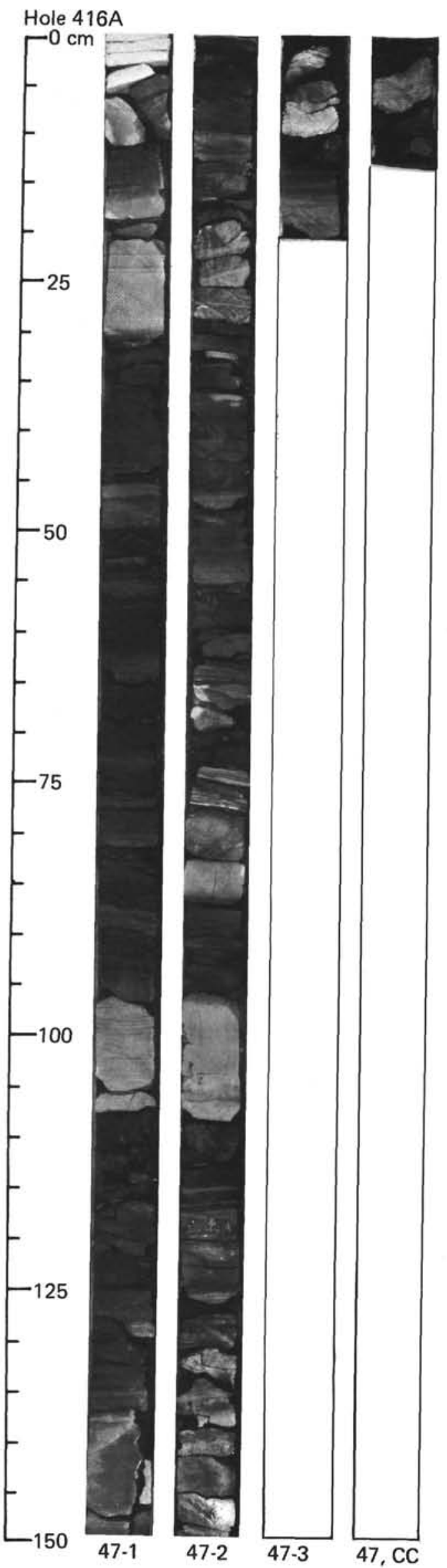




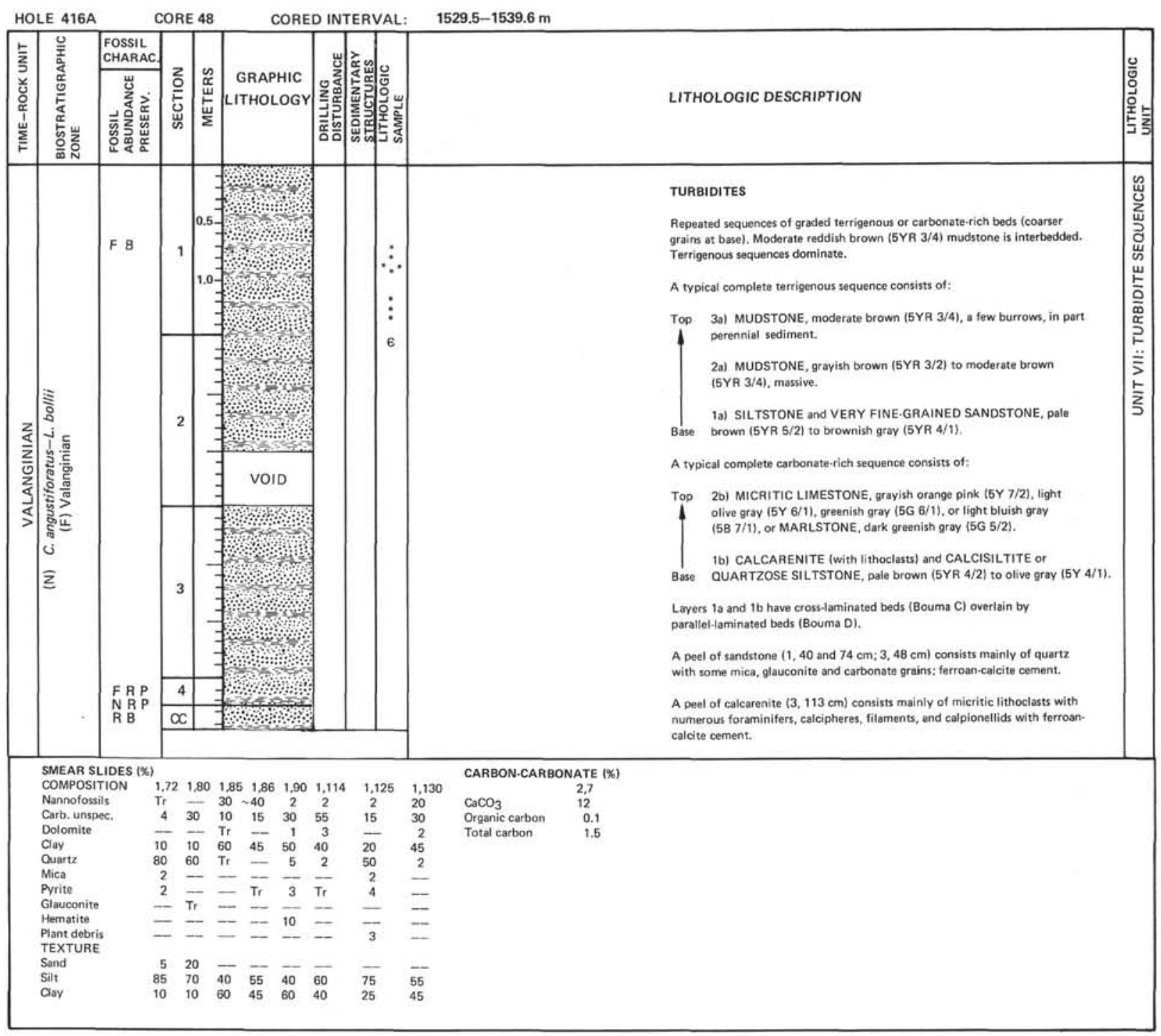


Hole 416A

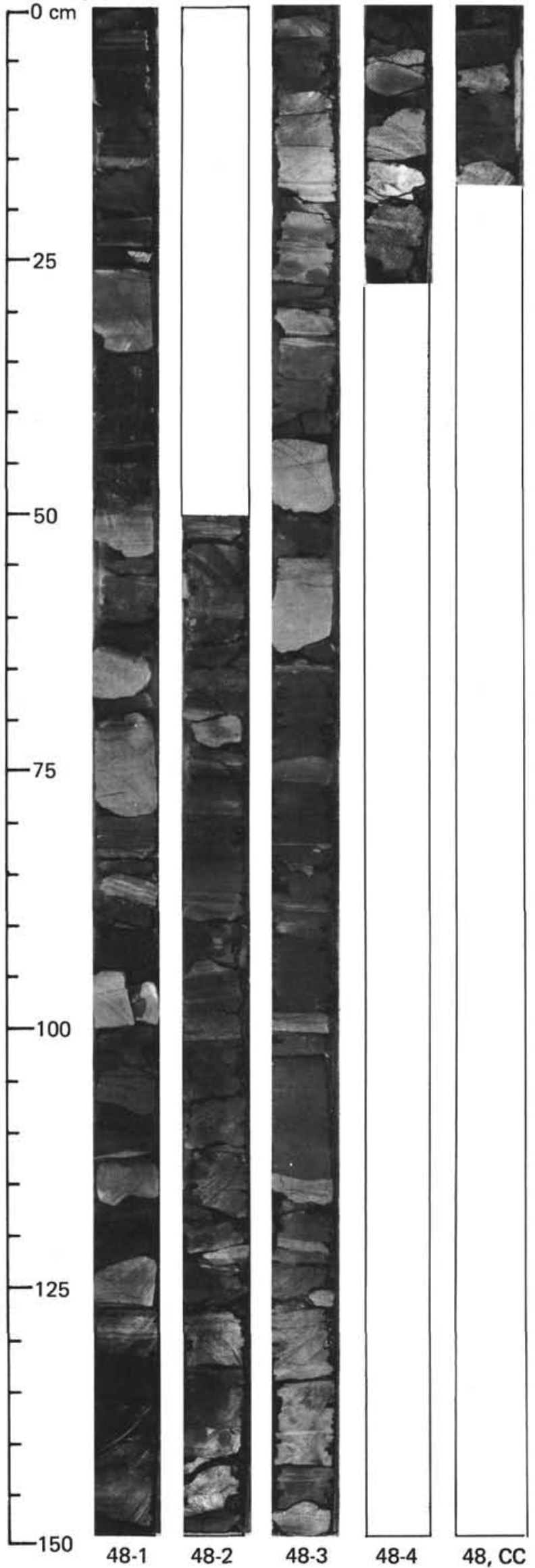




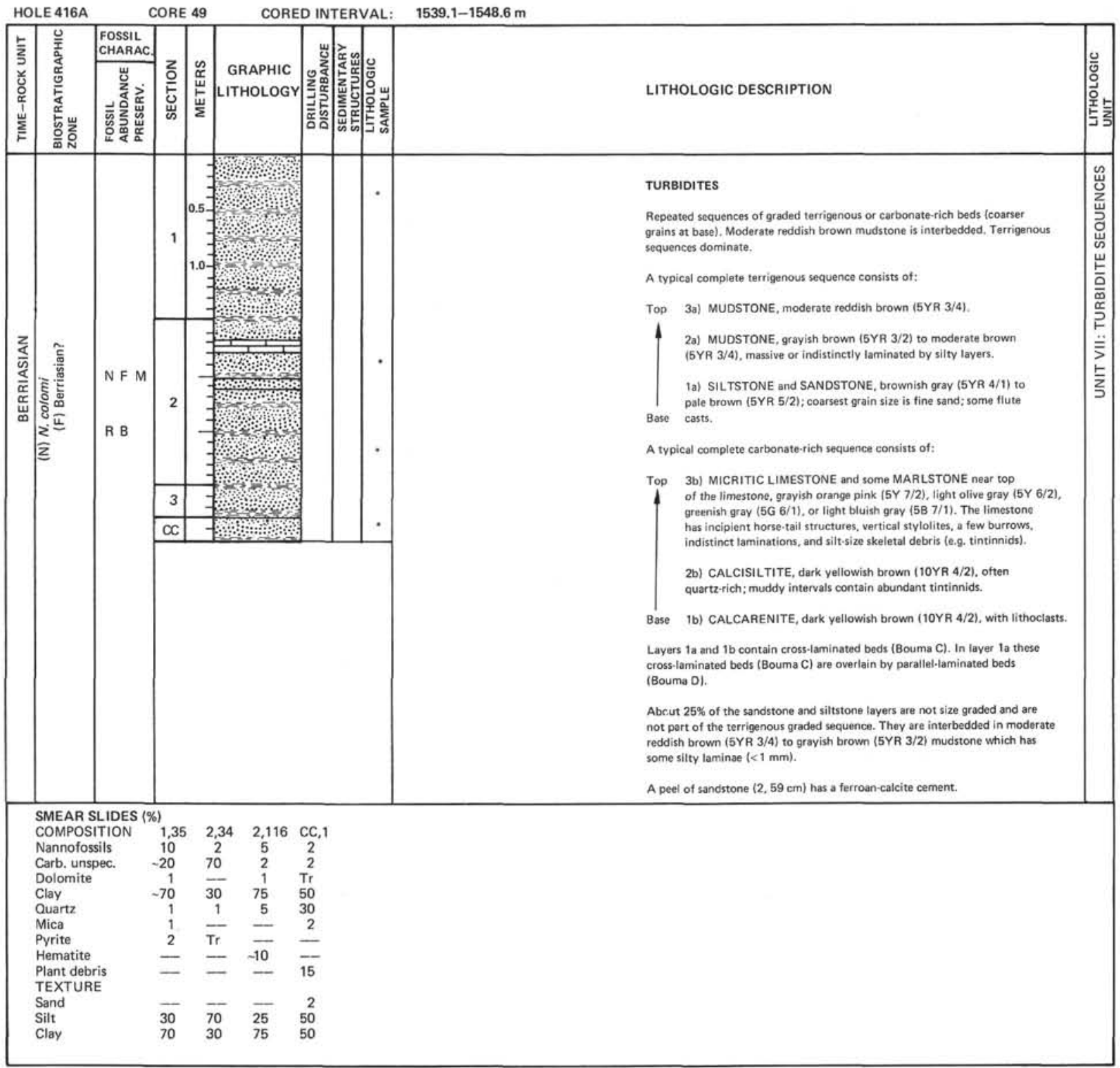


Hole 416A

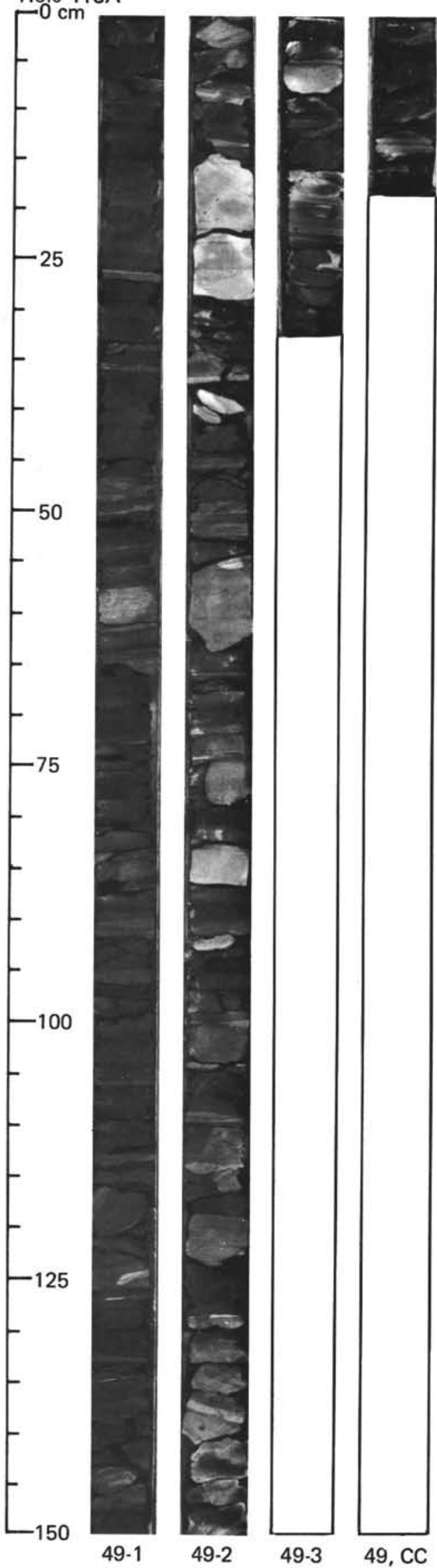




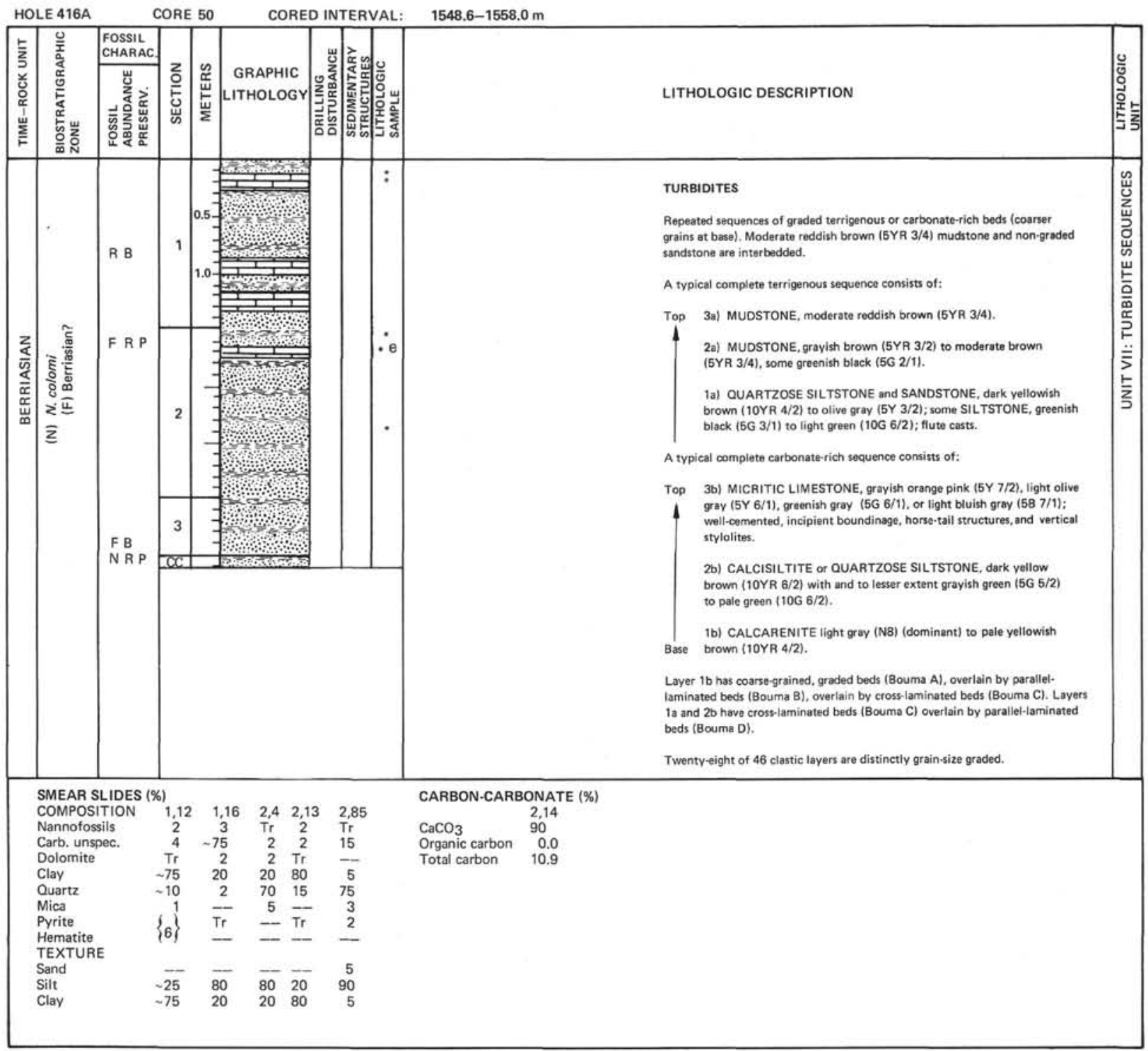


Hole 416A

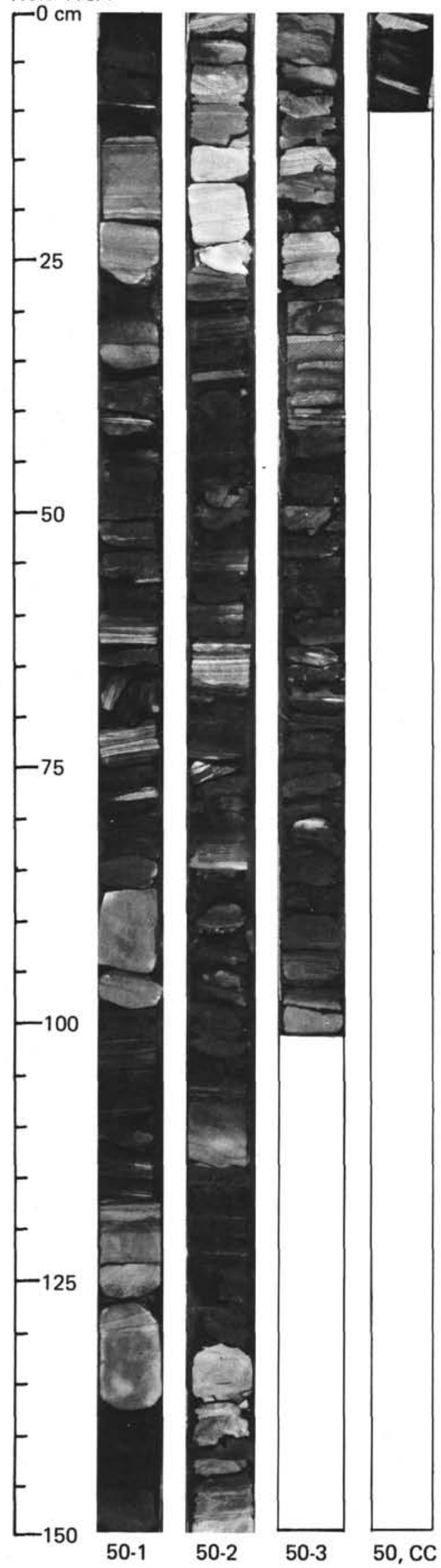




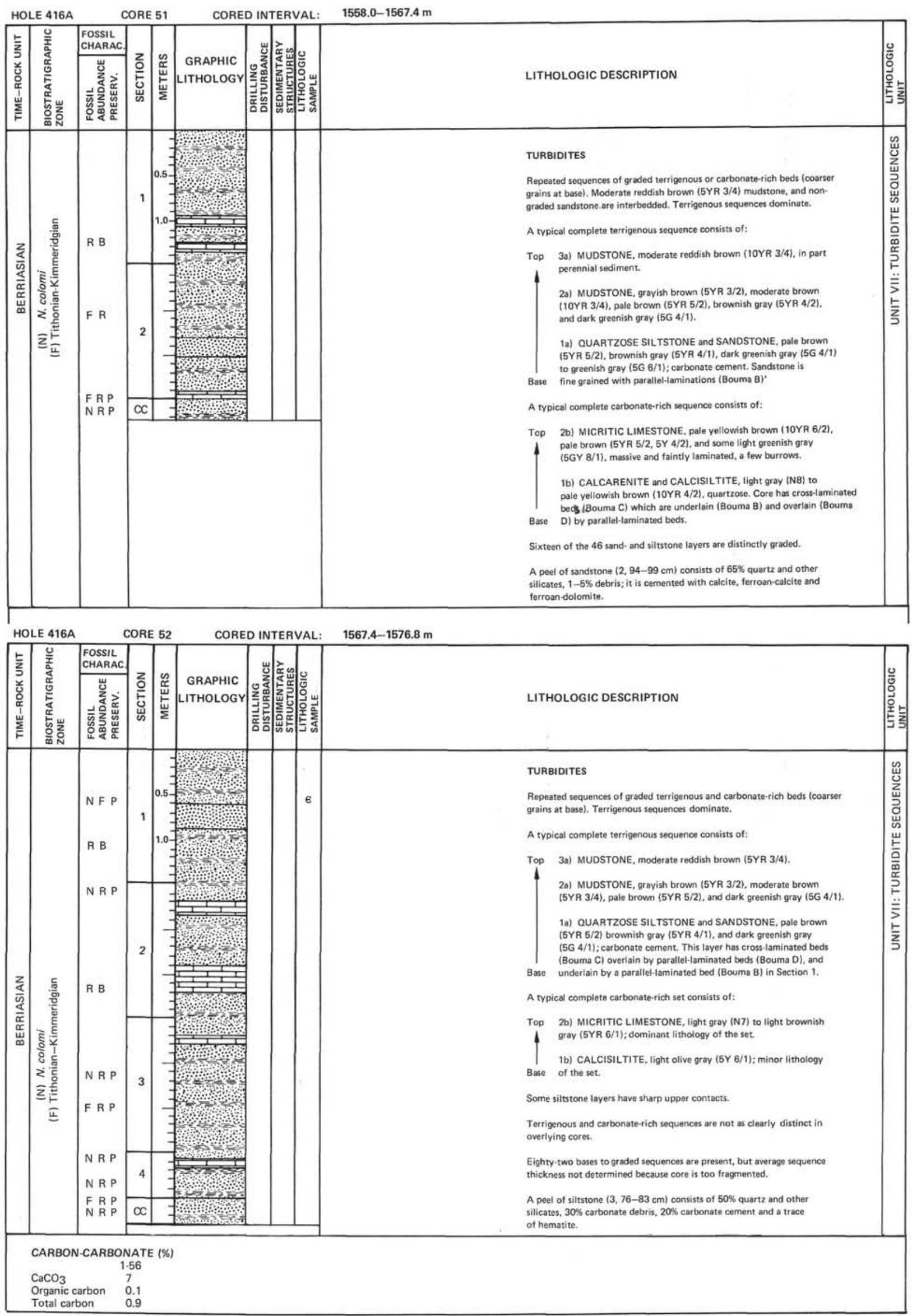


Hole 416A

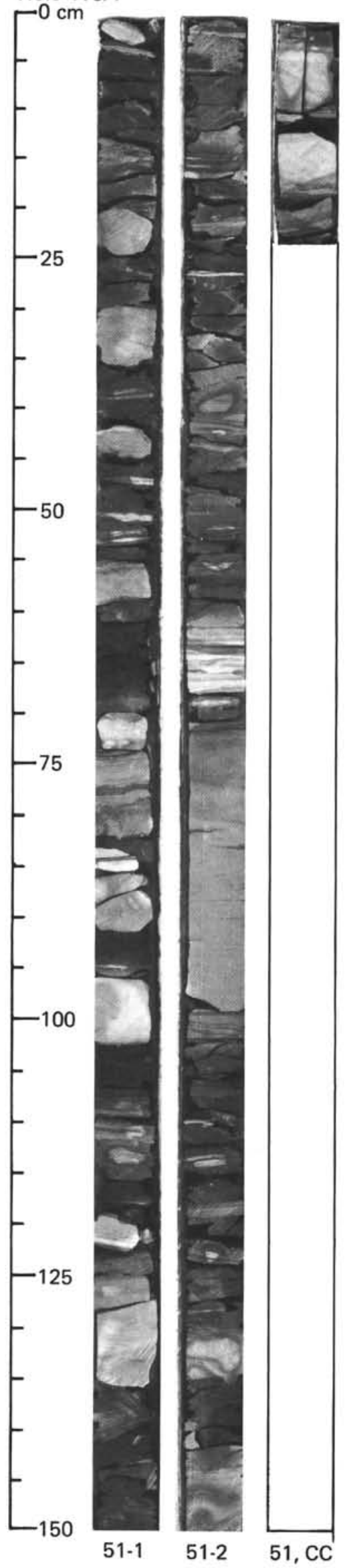

Hole 416A

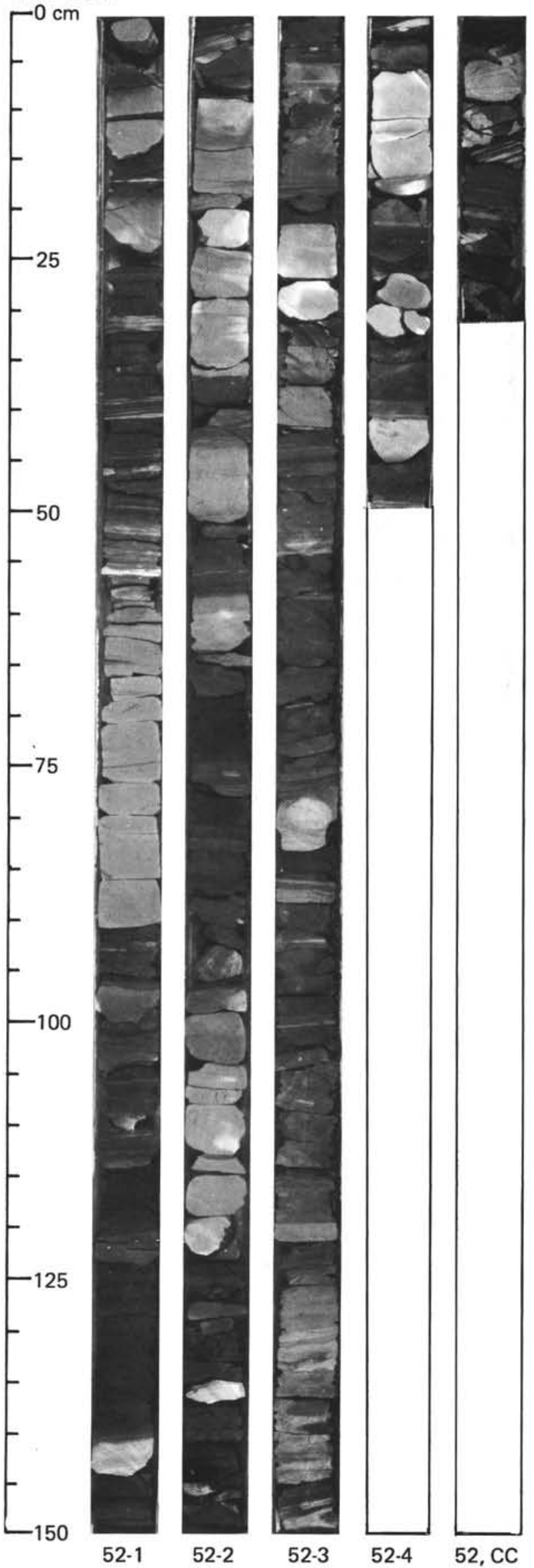




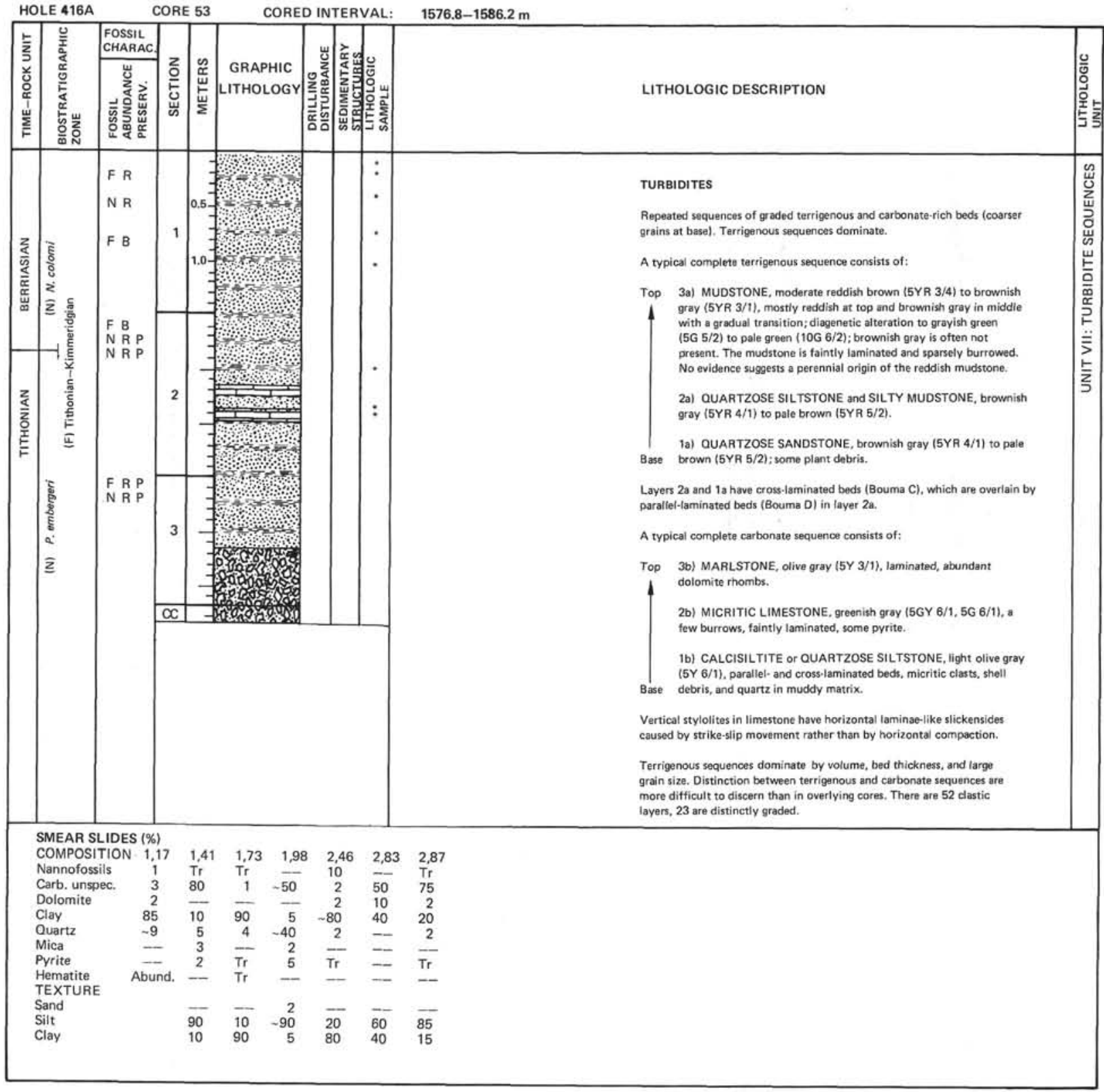




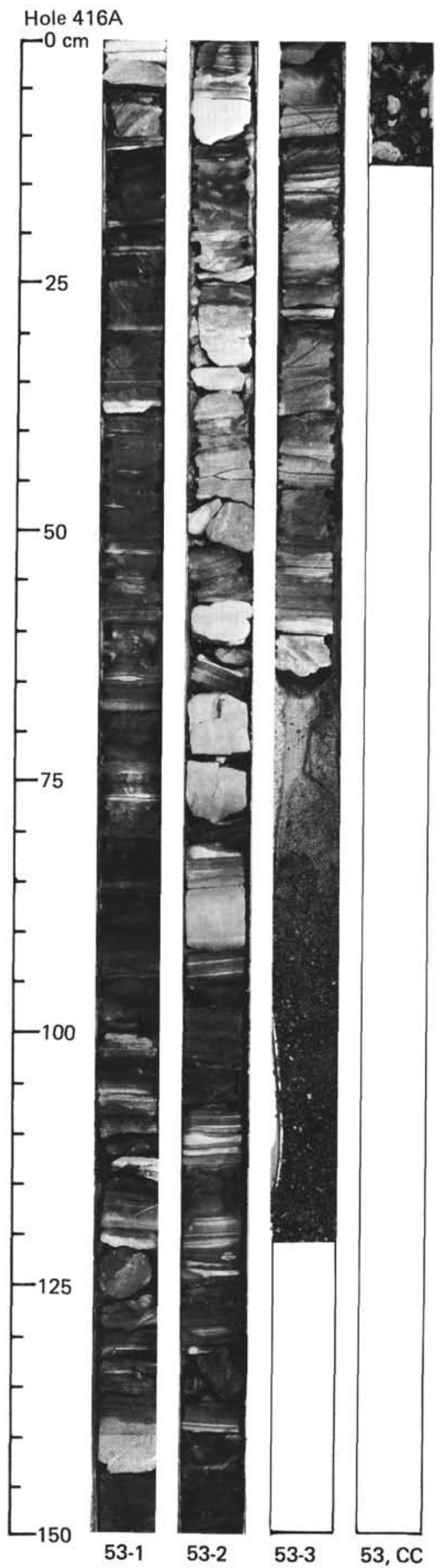




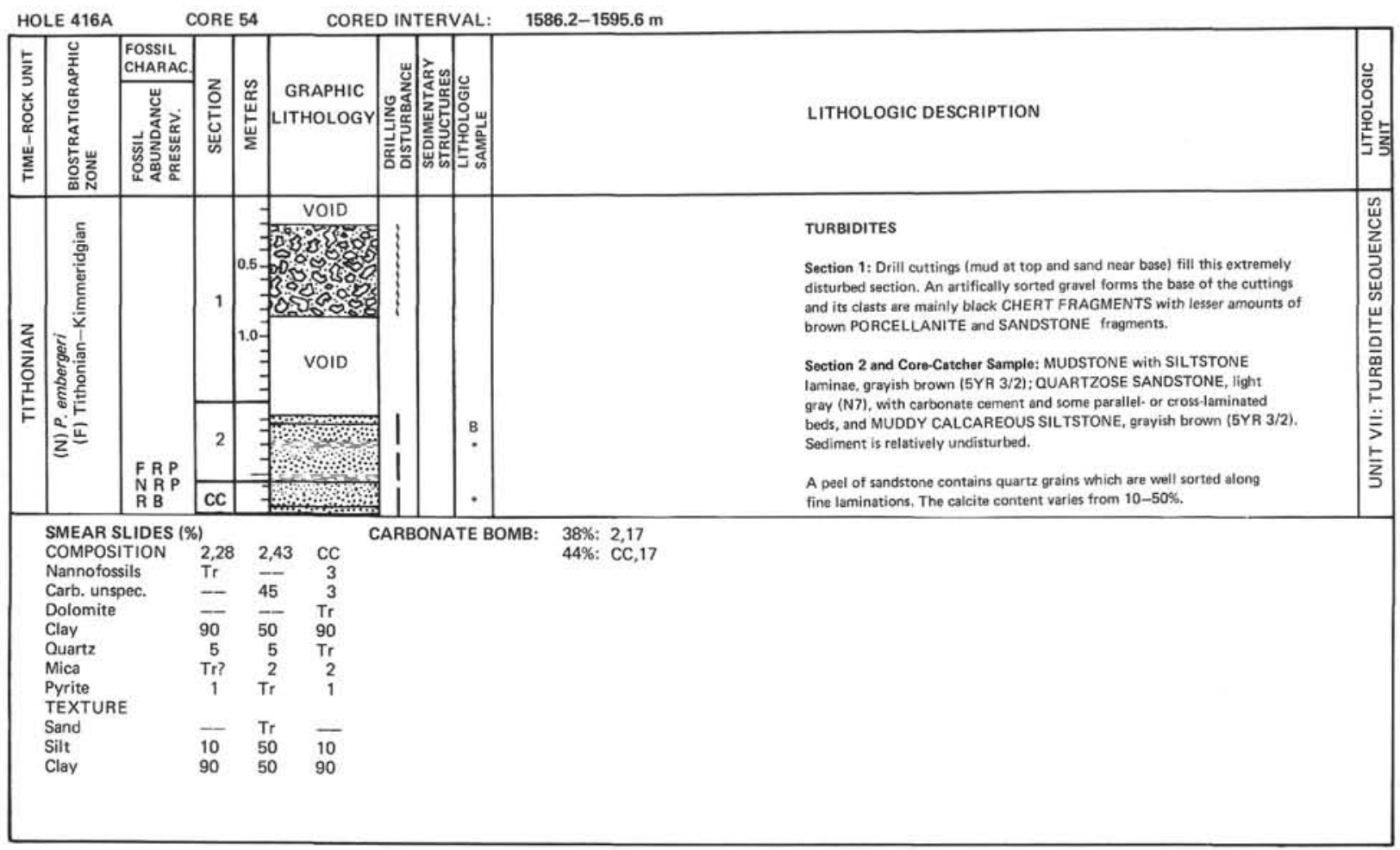

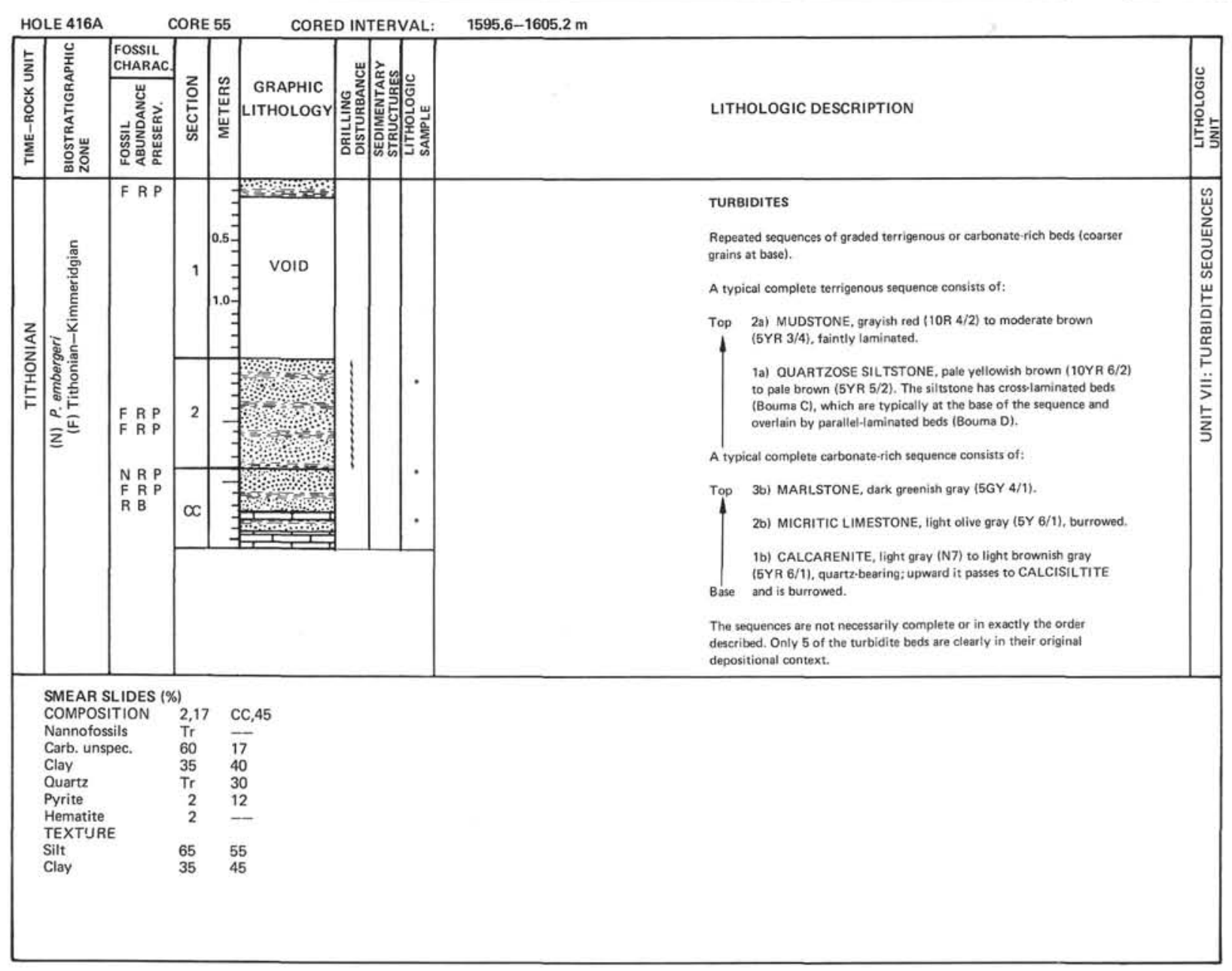


Hole 416A

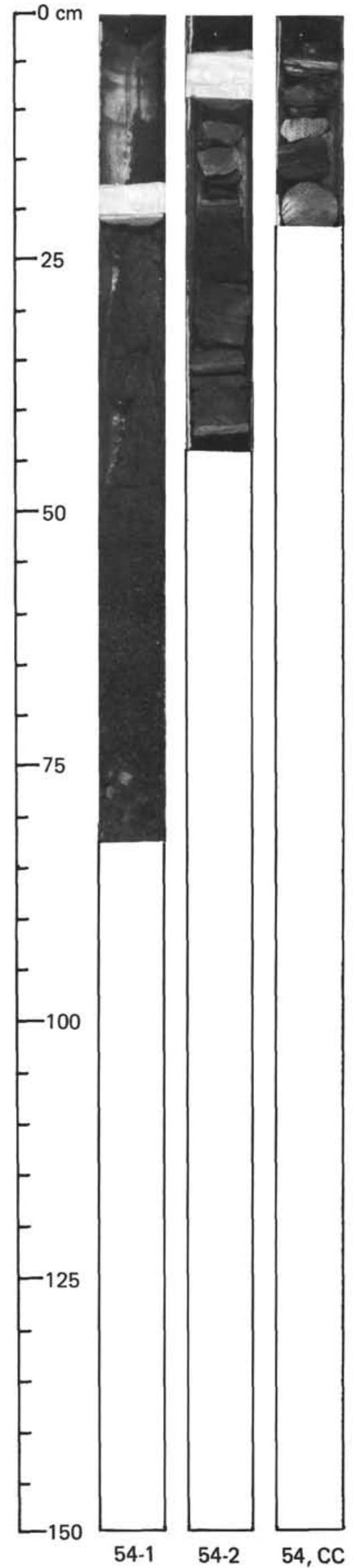

Hole 416A

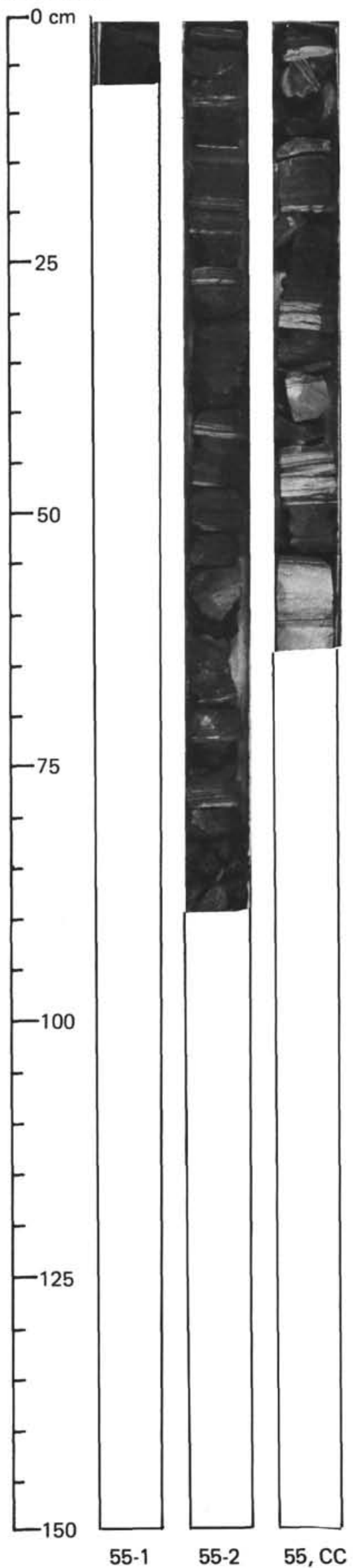




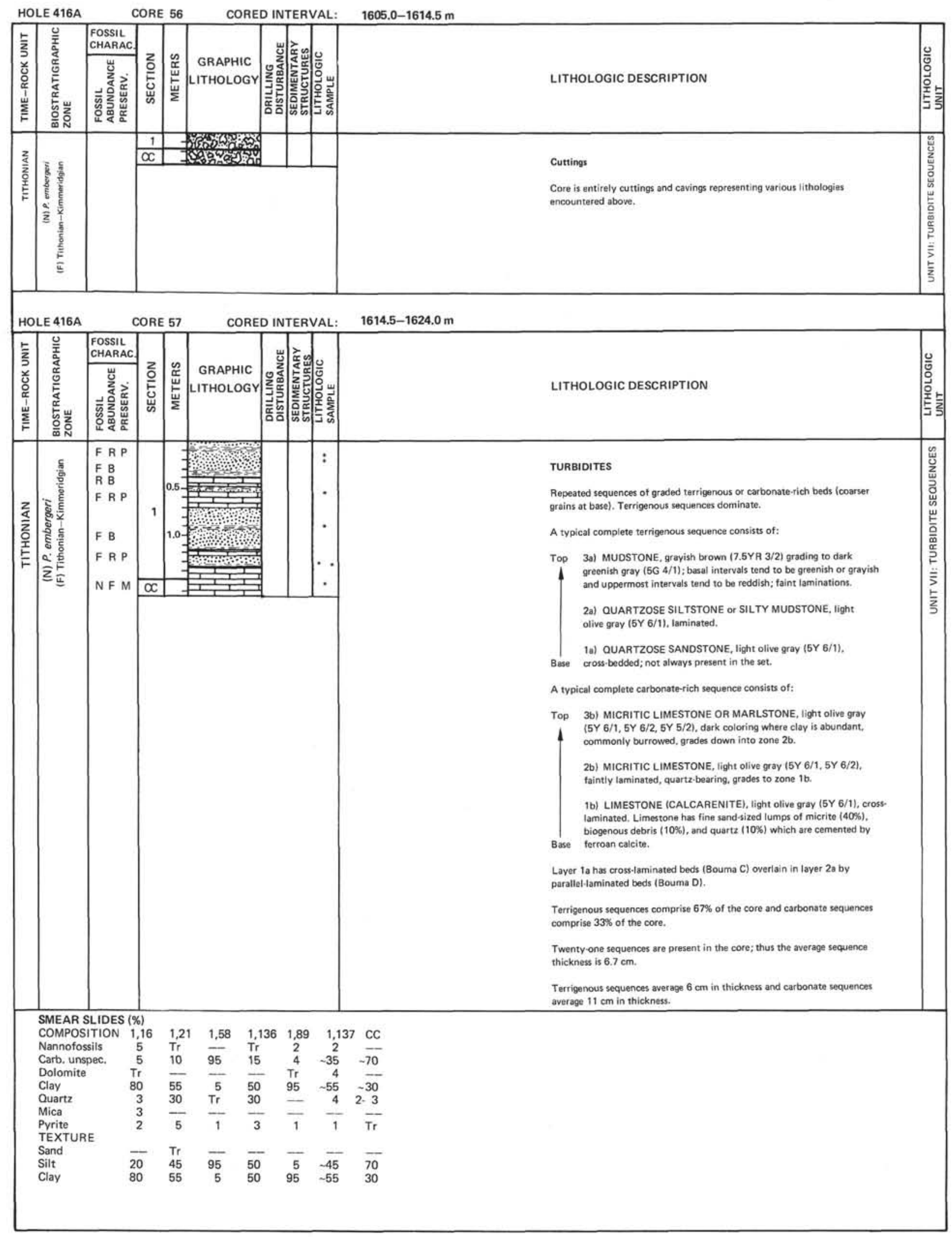


Hole 416A

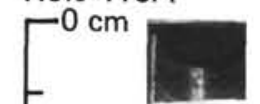

$$
-
$$

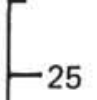

-

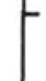
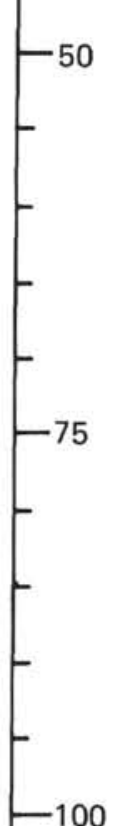

-

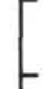

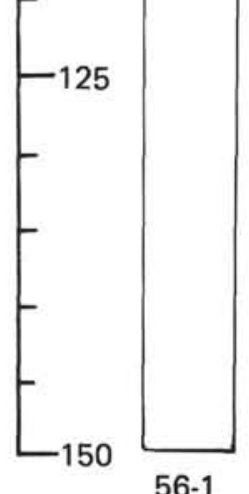

56-1

Hole 416A

$\Gamma^{0} \mathrm{~cm}$

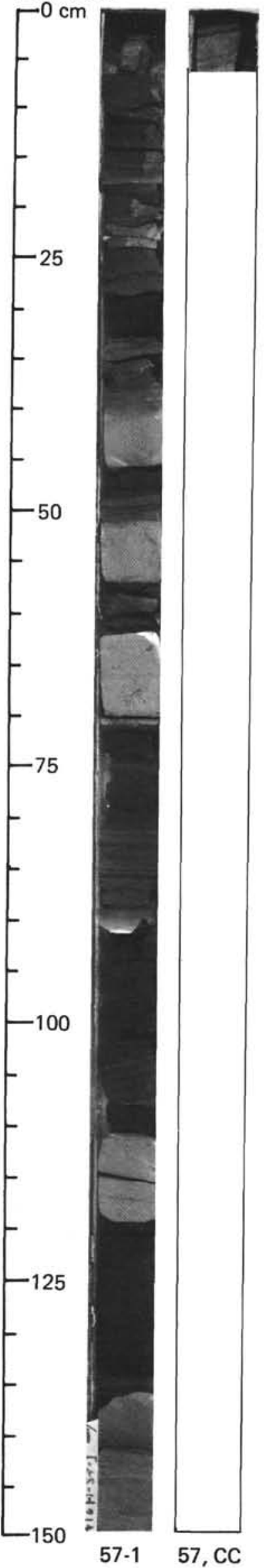

